\title{
Vi et Armis: Londoners and Violent Trespass Before the Common Pleas in the Fifteenth Century
}

\author{
Lindsey McNellis \\ West Virginia University, limcnellis@mail.wvu.edu
}

Follow this and additional works at: https://researchrepository.wvu.edu/etd

Part of the Legal Commons, Legal History Commons, and the Medieval History Commons

\section{Recommended Citation}

McNellis, Lindsey, "Vi et Armis: Londoners and Violent Trespass Before the Common Pleas in the Fifteenth Century" (2019). Graduate Theses, Dissertations, and Problem Reports. 4031.

https://researchrepository.wvu.edu/etd/4031

This Dissertation is protected by copyright and/or related rights. It has been brought to you by the The Research Repository @ WVU with permission from the rights-holder(s). You are free to use this Dissertation in any way that is permitted by the copyright and related rights legislation that applies to your use. For other uses you must obtain permission from the rights-holder(s) directly, unless additional rights are indicated by a Creative Commons license in the record and/ or on the work itself. This Dissertation has been accepted for inclusion in WVU Graduate Theses, Dissertations, and Problem Reports collection by an authorized administrator of The Research Repository @ WVU.

For more information, please contact researchrepository@mail.wvu.edu. 
Vi et Armis: Londoners and Violent Trespass Before the Common Pleas in the Fifteenth Century

\author{
Lindsey McNellis
}

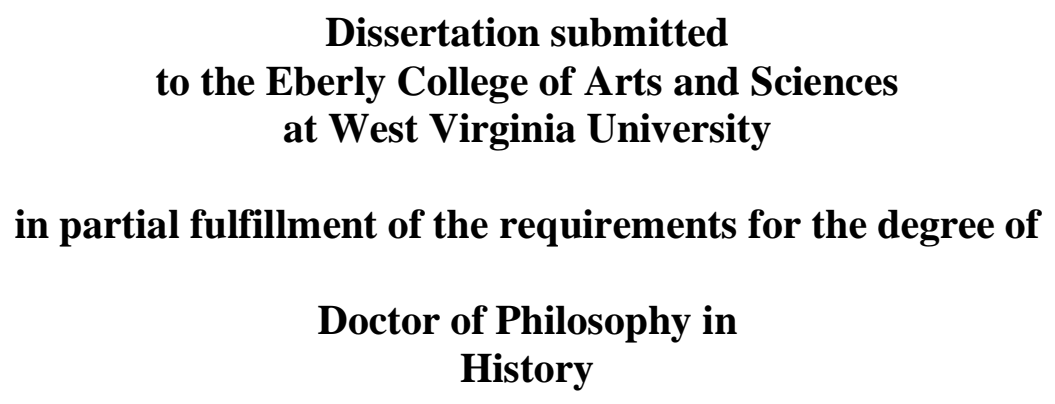

Kate Kelsey Staples, Ph.D., Chair

Matthew Vester, Ph.D

Shannon McSheffrey, Ph.D.

Ari Bryen, Ph.D.

Joseph Hodge, Ph.D.

Department of History

Morgantown, West Virginia

2019

Keywords: trespass, civil litigation, London, fifteenth century, violence, gender, status Copyright 2019 Lindsey McNellis 


\section{Abstract \\ Vi et Armis: Londoners and Violent Trespass Before the Common Pleas in the Fifteenth Century}

\section{Lindsey McNellis}

Civil litigation in early fifteenth-century England encompassed a variety of actions, but only one writ covered acts of violence: trespass vi et armis. These writs, all before the central Court of Common Pleas, detail a variety of violent torts, or wrongs, such as housebreaking, theft, imprisonment, abduction, and assault. The Londoners who entered pleadings in this court between 1405 and 1415 have left a fascinating glimpse into both interpersonal violence and the world of savvy litigators. Through a close examination of eighty-two cases, I demonstrate that Londoners were knowledgeable litigants who used the Court of Common Pleas and its procedures to pursue their agendas. However, two facts about the cases before the Court of Common Pleas indicate that plaintiffs had ulterior motives in going to law: cases rarely went to trial, and damages were hardly ever assessed. The narratives crafted by plaintiffs and defendants suggest complex motives which might include establishing property ownership, enforcing arbitration, as well as negotiating concepts of licit and illicit violence. Defendants might argue that certain acts, like violence in self-defense, were considered licit as the violence re-created order from the initial attack. These negotiations occurred not only between people and the crown, through the courts, but also among the people themselves, for example, during arbitration or during jury deliberations. Various layers of negotiations are perhaps best evidenced in the differences between using self-defense in a criminal proceeding and in a civil proceeding. Of particular importance in deciding something like the amount of money to request in damages was the status, occupation, and gender of the defendants. Knowing this information helped litigants assess the economic feasibility of obtaining damages that might have been awarded to them. Violence committed by or against women was, on average, assigned a monetary value that was less than violence by men against men. Similarly, litigants with an occupation or status listed in the records, resulted in damage requests that were twenty percent more than when litigants did not include occupation or status. In the last chapter, I place these eighty-two cases in the broader context of the fifteenth century. I examine a larger set of cases, including these eighty-two cases, statistically over a span of thirty-eight years in the fifteenth century and my findings reinforce the data from the smaller sample set; namely, that gender, occupation, and status influenced the amount of damages requested. This long-term data does hint at a change over time in what society and the courts felt was violence allowed by private parties against each other. As savvy litigants, Londoners would wield narratives of violence that might help their agenda, either as plaintiff or defendant, and they would also know when those narratives needed to match the changing societal concepts of violence. 
For Sherman 


\section{Acknowledgements}

How does one even begin to acknowledge the types of debt incurred while writing a dissertation? Just thinking about all the people who have touched this project and my life over the last seven years doesn't even begin to scratch the surface of all the people who have influenced my life; because life doesn't begin when you enter graduate school and it certainly doesn't stop while you're in it. Contemplating what to put here gives me a new appreciation for those award winners (pick one, Tonys, Oscars, Emmys) who get their speeches cut off by the music. Thankfully, I had to give my orchestra the sack during grad school budget cuts-bad for them, good for my long thank you speech.

It may seem unorthodox, but I'm going to start with my family and friends. I would not have been able to continue this long journey without the support of my mother, Diane, and my sister, Byrony. We don't say it enough: I love you both. Their faith in my abilities far surpass my own confidence and sometimes I needed that blind faith. Sometimes you also need to be reminded that grad school is only a part of your life. P.S., mom, the movie you're thinking of is Goonies. My father, Michael, continually supported my educational endeavors, and indeed first introduced me to how fascinating history can be. It is sad he didn't live to see this moment. I'm going to single out my dear friend, Jake Ivey, without whom I would never have found my way to West Virginia University. Even though he moved away soon after I arrived, he never stopped supporting my efforts and cheering me on.

Along the way, I also gained additional family, both Ph.D. and personal. While I'm still not sure whether to thank Megan for introducing me to her brother, even before I married him, she was a sister to me. Matt, my love, you are a gem among humanity, not only for putting up with me (and because you love me), but also for reminding me that sometimes good things happen in life, sometimes. For the many hours commiserating with me over writing, teaching, researching, and life, and even more the hours of laughter, I want to thank Megan, Cassie, Jennifer, Christine, Lacey, Shanequa, and Nilanjana. My work with the Graduate and Professional Student Senate brought me into contact with great people across the university, who shared in my triumphs and listened to my complaints; I appreciate every one of you, but especially I want to thank Will and 
Justin. Constinia Charbonette was not only an unflagging supporter who constantly promoted my endeavors and skills, but also taught me how to be my own champion - thank you. For the hours working alongside me and cheering me on from around the world, I want to thank my Thrive peeps: Katy, Janet, Emily, Jackie, My-Linh, and Carla. Katy and Michelle, especially, helped me navigate this last year of grad school with solid support and guidance.

Even with all of these awesome people guiding and supporting my journey, the dissertation itself would not have happened without the help of WVU's history department and my committee. First, in terms of the department, I want to thank Becky and Martha for always having an answer when I needed it. I would also like to thank Dr. Tamba M'bayo for his gentle guidance and support for my writing and teaching. Additionally, I greatly appreciate Dr. Kim Welch's help during the early stages of this study. To the members of my committee: Kate Staples, Shannon McSheffrey, Matthew Vester, Ari Bryen, and Joseph Hodge, thank you. Dr. Hodge took the time early in my graduate career to help shape my writing and continued to do so with my dissertation. Dr. Bryen first shifted my focus to violence and for that I am eternally grateful, but he has continued to encourage me to hone my writing and analysis by reading outside the fifteenth century. Dr. McSheffrey has expanded my knowledge of fifteenth-century London courts and has helped push me to rethink how I can use court records; her work is an inspiration. Dr. Vester's enthusiasm for history and research was catching and I looked forward to what new directions his ideas might take me.

Dr. Kate Staples has been my bastion throughout this process. Unfailingly kind, encouraging, and challenging all at the same time, she continues to push me to become the best scholar and person I can be. I count myself fortunate she decided to take me on as a student. Her mentorship has helped guide me through the shoals of both personal and professional crises. She also, on occasion, let me snuggle with her adorable dog, Stella (especially helpful after my Sherman died).

I would also like to thank the Medieval Academy of America and the Richard III SocietyAmerican Branch for awarding me the Schallek Fellowship for 2018-2019, without which I would not have been able to finish my dissertation this year. 


\section{Table of Contents}

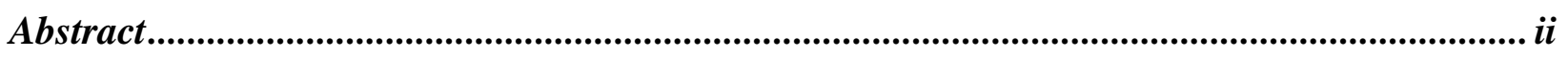

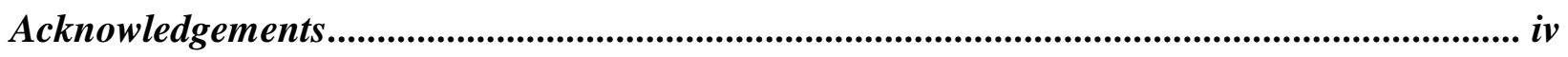

List of Figures ...................................................................................................................... vii

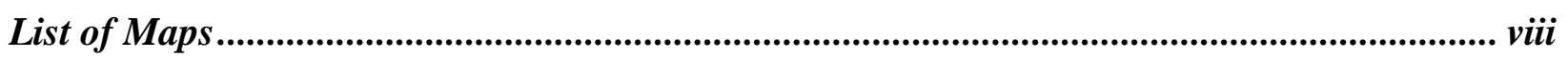

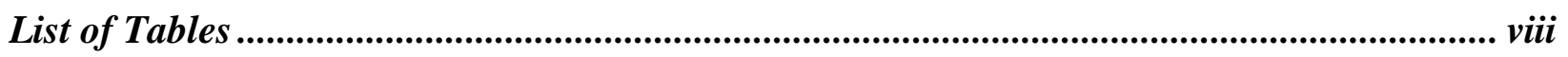

List of Images .................................................................................................................................. viii

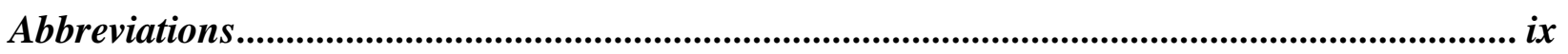

Chapter 1 - Trespass vi et armis and the Common Pleas .......................................................... 1

Disparate Views of Law and Order.................................................................................................

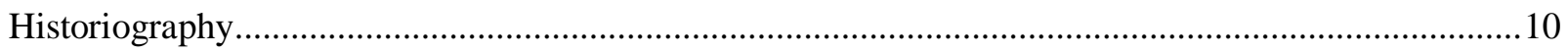

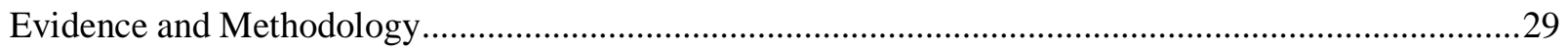

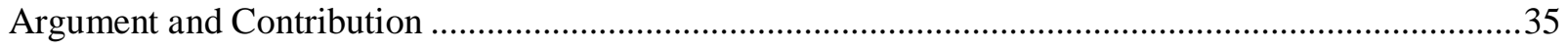

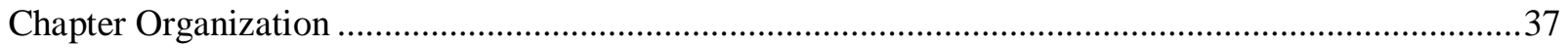

Chapter 2 - The Legal Worlds of Medieval England .................................................................... 43

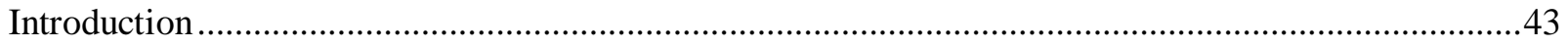

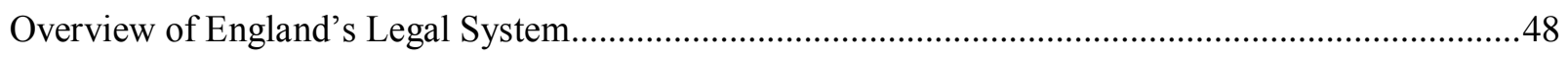

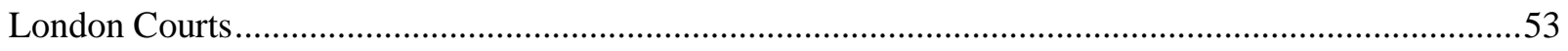

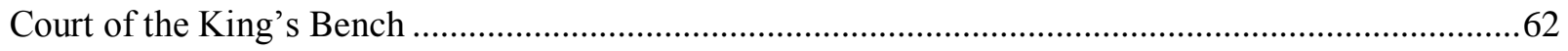

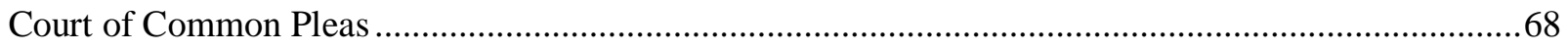

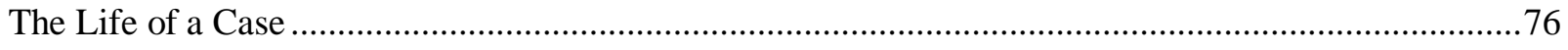

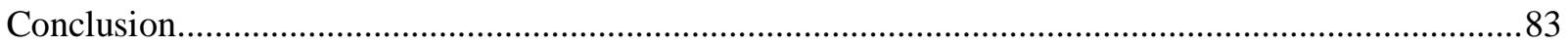

Chapter 3 - Savvy Litigators: Creating Order from Chaos.......................................................... 88

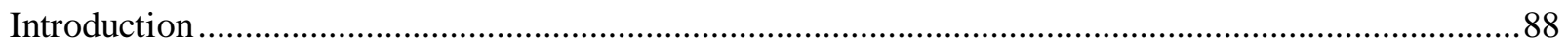

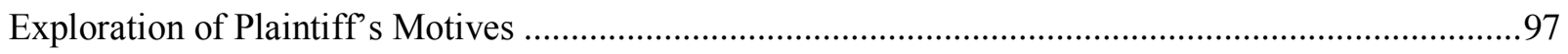

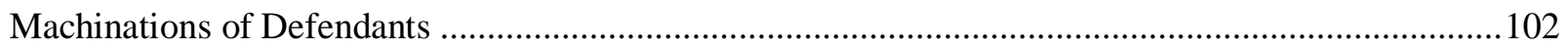

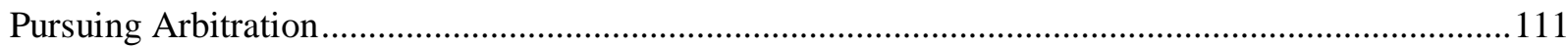

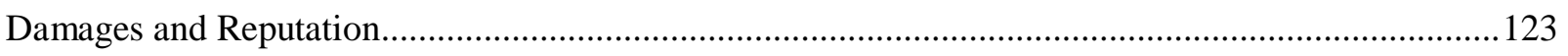

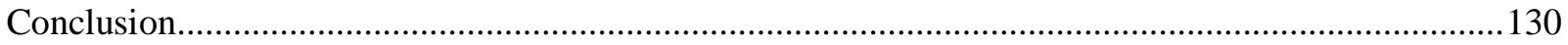

Chapter 4 - In Fear for their Lives: Assault and Self-Defense ................................................ 135

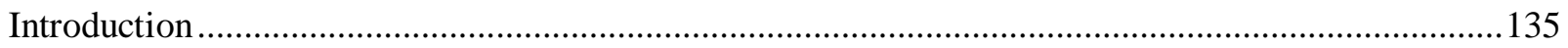

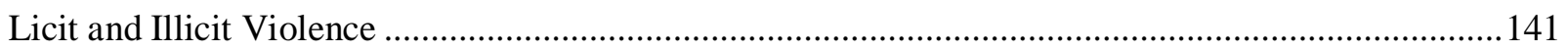

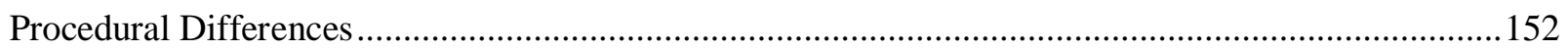

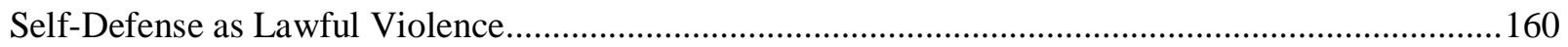




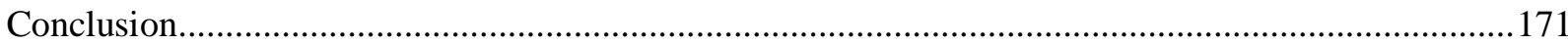

Chapter 5 - Pursuing Justice: A Century of Force and Arms ............................................. 175

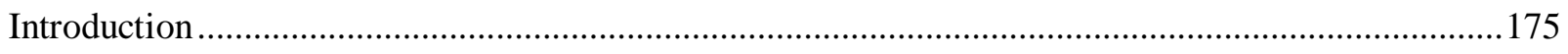

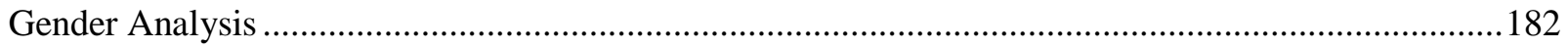

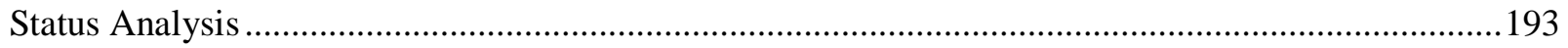

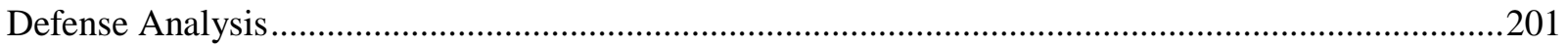

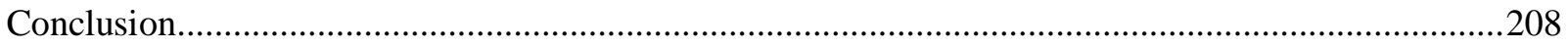

Epilogue - A Case for the Court of Common Pleas............................................................ 213

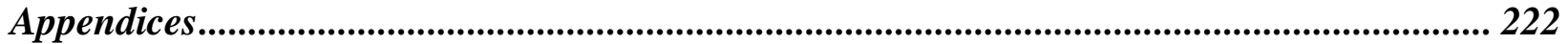

Appendix A: Litigants in Trespass vi et armis Cases Between 1405 and 1415 (Broken Down By

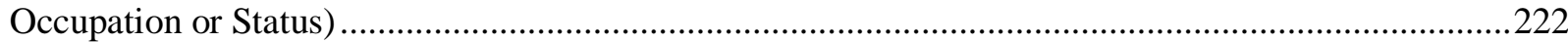

Appendix B: Image of a Court of Common Plea roll (CP 40/572) from The National Archives, Kew,

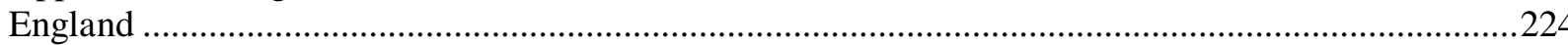

Appendix C: Dates of Law Terms between 1405 and 1415, with corresponding Common Plea headings

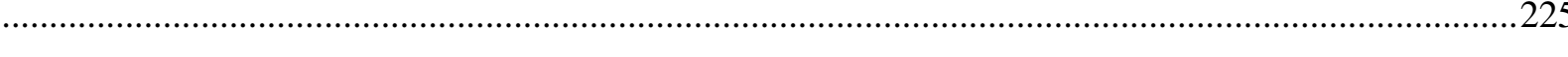

Appendix D: Visual Representation of Court System in England, c. Fifteenth Century .....................226 Appendix E: Image of CP 40/576, rot. 250 from The National Archives, Kew, England.....................227

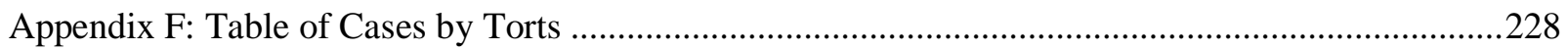
Appendix G: Example of Information Contained in "Court of Common Pleas: The National Archives,

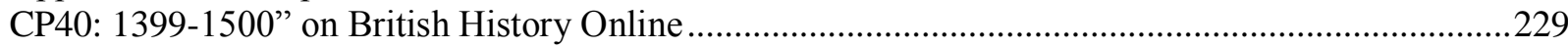

Appendix H: Images of FileMaker database created and used for this dissertation ...........................230

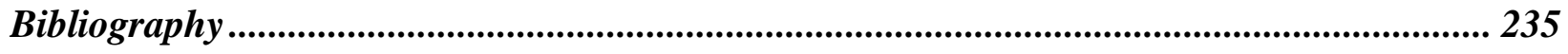




\section{List of Figures}

Figure 1 - Breakdown of Cases by Weapons Listed .............................................................. 125

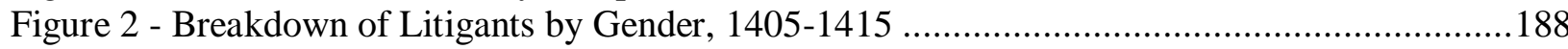

Figure 3 - Breakdown of Litigants by Gender, 1400-1500 ..................................................... 189

Figure 4 - Women Appearing in the Common Pleas .......................................................... 190

Figure 5 - Breakdown of Average Damage Requests in Pounds by Torts, Separated by Cases Which

Include Women and Cases Which Only Include Men ...........................................................192

Figure 6 - Number of Litigants with Status or Occupation Listed............................................. 199

Figure 7 - Average Amount of Damage Requests in Pounds in Cases Listing Status and Occupation

\section{List of Maps}

Map 1 - London and Westminster, circa 1405

Map 2 - Parishes and Wards in London, 1405-1415 ..............................................................134

\section{List of Tables}

Table 1 - Details for Cases About Damages and Reputation ...................................................... 103

Table 2 - Details for Cases in which Defendants Pleaded Prior Arbitration .................................113

Table 3 - Cases With Assault Broken Down by Tort Category .................................................. 140

Table 4 - Details for Thirteen Cases with Multiple Torts....................................................... 146

Table 5 - Details for Cases in which Defendants Used Self-Defense .......................................161

Table 6 - Breakdown of Cases by Defense Pleading ….......................................................203

Table 7 - Litigants in Trespass vi et armis Cases Between 1405 and 1415 (Broken Down By

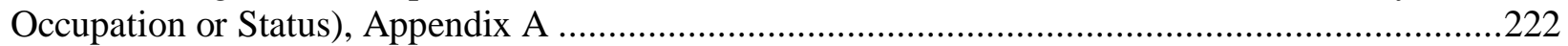

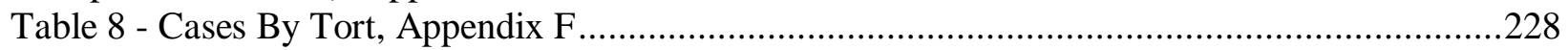

\section{List of Images}

Image 1 - Court of Common Plea roll (CP40/572), Appendix B ...............................................224

Image 2 - Parts of a Case, Using CP40/572, rot. 250, Appendix E ..............................................227

Image 3 - Example of Main Entry Information, FileMaker Screenshot, Appendix H ..................230

Image 4 - Another Example of the Main Entry Information, FileMaker Screenshot, Appendix H...230

Image 5 - Example of Person Entry Information, FileMaker Screenshot, Appendix H.................231

Image 6 - Another Example of Person Entry Information, FileMaker Screenshot, Appendix H ......231

Image 7 - Example of Tort Entry Information, FileMaker Screenshot, Appendix H ...................232

Image 8 - Example of Notes Entry, FileMaker Screenshot, Appendix H ................................2232

Image 9 - Example of Transcription and Translation Entry, FileMaker Screenshot, Appendix H....233

Image 10 - Example of Report Run Giving Average Damages in Pounds and Shillings for Assault

Cases with Female Litigants, FileMaker Screenshot, Appendix H...........................................233

Image 11 - Example of Report Run Giving Average Damages in Pounds and Shillings for Assault

Cases with Male Litigants, FileMaker Screenshot, Appendix H ..........................................2234 


\section{Abbreviations}

AALT Anglo-American Legal Tradition

BHO British History Online

CP The Court of Common Pleas

LMA The London Metropolitan Archives

OED Oxford English Dictionary

TNA The National Archives in Kew, England 


\section{Map 1 - London and Westminster, circa 1405}

Overview of London and Westminster around 1405. Included are the wards of London, the wall surrounding London, some major and minor roads, as well as Westminster Hall.

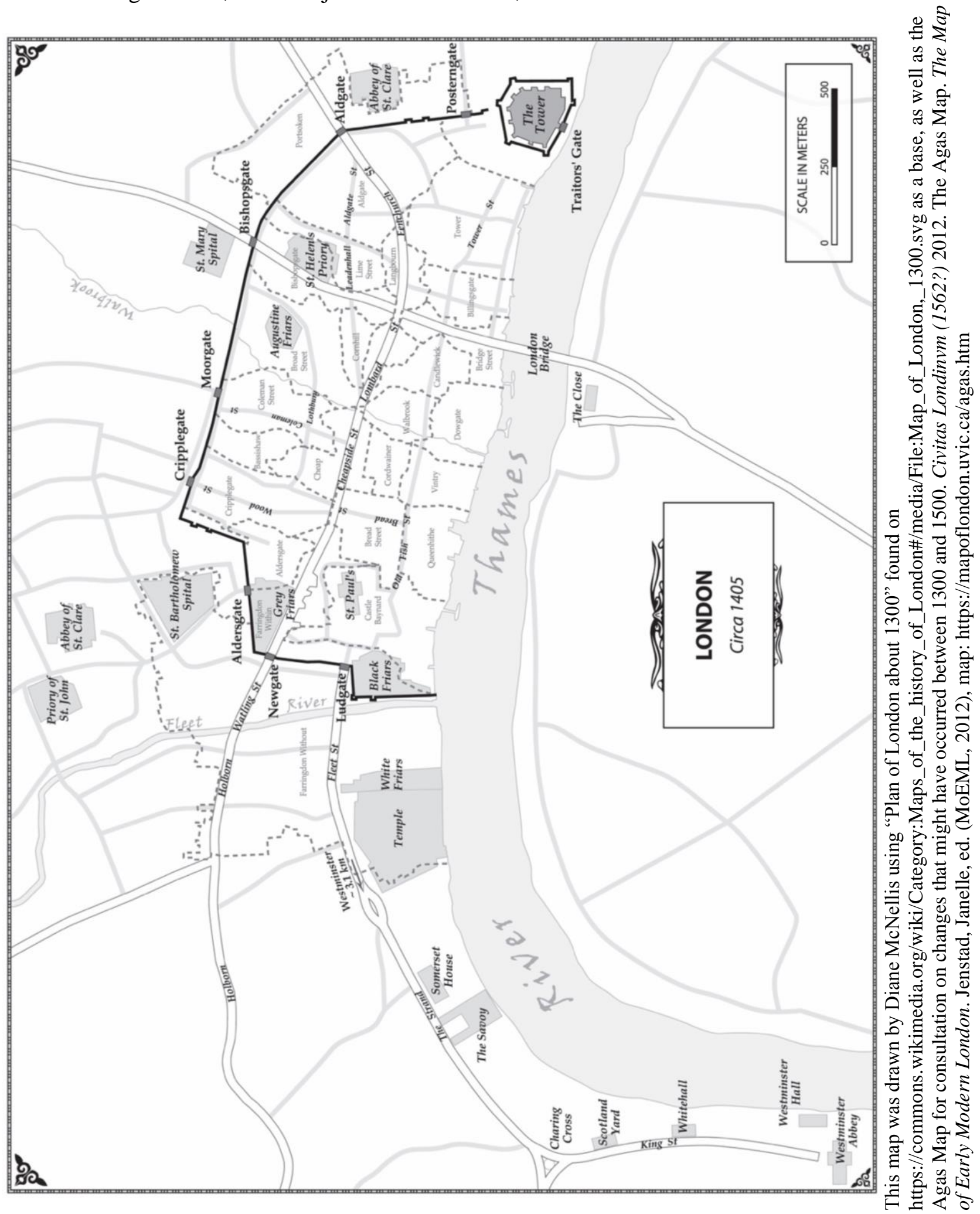




\section{Chapter 1 - Trespass vi et armis and the Common Pleas}

\section{Disparate Views of Law and Order}

When Geoffrey Creyk and Robert Capon appeared in court during the Michaelmas term of 1405 , little did they know that their dispute would be of interest to a historian 614 years later. Their case centers around Creyk's allegations that Capon had broken into his home, assaulted him, and stolen items from his home. ${ }^{1}$ Capon, in his plea, claimed to have been acting on orders for an ecclesiastical court, searching for a woman thought to be at Creyk's home. In his rejoinder, Creyk denied knowing anything about the woman and argued that having a summons did not exculpate Capon. This case is illustrative of a major theme (savvy litigators) and subtheme (conceptualizations of what constituted licit violence) of this dissertation. Both Creyk and Capon hired attorneys to help them present sophisticated arguments before the Court of Common Pleas. Within those narratives, the records present a key argument over conceptualizations of violence: Capon asserted his violence on behalf of another court was licit, while Creyk argued it was not. It also demonstrates the frameworks within which these knowledgeable litigants operated: the political, legal, and social worlds of fifteenth-century England.

In this dissertation, I examine how litigants navigated within the frameworks of law, politics, and society to pursue their aims; in other words, I analyze the practice of litigants before one primary legal court, the Court of Common Pleas, and one type of tort, to explore what it can reveal about their knowledge of the systems at their disposal, manipulation of the social norms in place, and, in some instances, negotiations over concepts of licit and illicit violence. Before examining the sources themselves, and Creyk v. Capon in particular, it is important to briefly

\footnotetext{
${ }^{1}$ The National Archives, CP 40/579, rot. 552; hereafter, TNA. I will discuss this case in more detail in chapter four.
} 
outline the evolution of law in relation to violent acts, disparate views of law and order, as well as some of the political background needed to provide a better context for the cases which make up the core of this dissertation. ${ }^{2}$

For many people, law and order comes from above, from government officials creating laws and courts to enforce them; law and order is something imposed on a populace. For others, the judges, lawyers, and others who participate in the legal system manipulate the laws and courts in order to achieve their own views of law and order. Legal theorists argue the merits and drawbacks of each view, but most scholars of legal history know that law and order is more of a combination of these two disparate views. Even with a definitive dichotomy between law and order or licit and illicit action, reality blends them into an organic system that is continually in flux.

Successive Anglo-Saxon kings began establishing rules regulating when and how interpersonal violence, usually violence for the sake of vengeance, could occur. ${ }^{3}$ Rather than banning 'self-help' violence and violent vengeance, these kings sought to insert themselves into the process, thereby gaining some measure of control. ${ }^{4}$ By self-help violence, I mean asserting a perceived right through aggressive action (e.g. taking goods to recover a debt). By violent vengeance, I mean violence that was perpetuated by private individuals to remedy an injury (real or perceived). It was during Henry I's reign (r. 1100-1135), though, that the link between being

\footnotetext{
${ }^{2}$ The idea of this framework was adapted from Chris Wickham's work on twelfth-century Tuscany in which he uses a similar framework of legal theory and institutional history in his examination of dispute settlement. Chris Wickham, Courts and Conflict in Twelfth-Century Tuscany (Oxford: Oxford University Press, 2003), 3-5. ${ }^{3}$ For more on the establishment of rules and the laws themselves, see T. B. Lambert, Law and Order in AngloSaxon England (Oxford: Oxford University Press, 2017); F.L. Attenborough, The Laws of the Earliest English Kings (New York: Russell \& Russell, 1963); A.J. Robertson, The Laws of the Kings of England from Edmund to Henry I (New York: AMS Press, 1974).

${ }^{4}$ For more on the ideas of a personal right to violence in the early Middle Ages, see Richard A. Fletcher, Bloodfeud: Murder and Revenge in Anglo-Saxon England (Oxford: Oxford University Press, 2003), 13-57; Paul R. Hyams, "Feud and the State in Late Anglo-Saxon England," Journal of British Studies 40, no. 1 (2001), 9-15; Patrick Wormald, Legal Culture in the Early Medieval West: Law as Text, Image, and Experience (London: Hambledon Press, 1999). In particular, see Patrick Wormald's chapter on regulating conflict, pages 333-357.
} 
able to establish and keep order in a kingdom and one's right to rule was firmly established. This link was not exclusive to England, nor was it necessarily an invention of Henry I. One can see the link between order and ruling as far back as the Roman Empire, into the Merovingian dynasty, and most explicitly established during Charlemagne's rule (r. 768-814). Under Henry I's administration, the idea of the crown regulating violent vengeance, rather than having a monopoly on it, continued. He offered a different avenue in which people could pursue that vengeance, violent or otherwise: his courts. ${ }^{5}$ While it may have been adopted as a way to legitimize a king's power, the ideology linking law, order, and good rulership seeped into the psyche of the people over the years. ${ }^{6}$

Having fully formed as a legal action by 1297, trespass vi et armis was relatively new in the grand scheme of the English legal system. Its creation is a prime example of the law adapting to societal pressures. As the law moved away from Anglo-Saxon fine systems, Englishmen and women sought ways to gain recompense for a wrongful act in ways that did not necessitate an appeal of a misdemeanor or felony; thus, after a lengthy process, trespass vi et armis came to be. However, this also meant that victims of violence had options as to how they wanted to pursue their alleged perpetrators. Both plaintiffs and defendants could benefit from civil procedures, especially trespass actions. Englishmen had long negotiated with the crown's legal representatives over concepts of licit and illicit violence and in trespass vi et armis actions defendants illustrate, through their narratives, that private individuals could instill order, legitimately, through the use of violence.

\footnotetext{
${ }^{5}$ Paul R. Hyams, Rancor \& Reconciliation in Medieval England (Ithaca: Cornell University Press, 2003 ), 137-45.

${ }^{6}$ For example, when John Watts evaluates the differences in political opposition rhetoric between the fourteenth and fifteenth century, he argues there was a stronger emphasis on central authority infringing on individual privileges in the fourteenth century. By the fifteenth century, the emphasis had shifted to what a proper king and his council should be doing to protect people. John Watts, The Making of Polities (Cambridge: Cambridge University Press, 2009), 8 .
} 
To be clear, when one talks about violence and medieval people's relationship with it, one has to define the term itself, and its context. Under the umbrella of trespass vi et armis cases, the source base for this dissertation, violence denoted a violation of a person or their property. This could be a physical act of violence, such as the alleged assault by Capon in the opening case, but it could also mean the threat of physical violence, the destruction of or damage to property, as well as the taking of people or property. ${ }^{7}$ Even if Creyk had not accused Capon of the physical assault, the alleged breaking into his home and the theft of his goods would both count as violence under medieval law and social views. ${ }^{8}$ Violence in ninth-century England was viewed distinctly, in both law and society, from that of fourteenth-century England. For example, the punishment for killing another person in Anglo-Saxon England depended on whether the act had occurred in secret or in the open; secret killings were punishable by death, open killings resulted in fines. ${ }^{9}$ However, by the fourteenth century, any killing, secret or open could be punishable by death according to the laws, but juries often factored in intent when deciding the culpability of the defendant. ${ }^{10}$ In other words, notions of violence were culturally constructed. Instead of rebelling against the idea of a ruler forcing people to accept a pre-set idea of law and order, Englishmen and women began to use the courts to pursue their self-interests, thus

\footnotetext{
${ }^{7}$ In the legal system of the modern United States, these same types of offenses constitute a variety of criminal activity and are classified based on threat, use of weapons, and personal presence of the victim. None of these distinctions were made in the late Medieval English system. See J.G. Bellamy, The Criminal Trial in Later Medieval England: Felony Before the Courts From Edward I to the Sixteenth Century (Toronto: University of Toronto Press, 1998), 36-37. For example, under trespass vi et armis, the records show that there was no distinction between whether items were stolen from a person, an occupied home, or an empty home. This civil action also does not distinguish over the use of weapons, as the writ language indicates the presence of weapons in almost all cases. However, in the modern United States legal system, there is a distinction in criminal law between larceny (theft of goods from a person) and armed, or aggravated, robbery (theft of goods from a person with the use of, or threat of, weapons).

${ }^{8}$ Bellamy, The Criminal Trial in Later Medieval England, 36-37.

9 Thomas A. Green, "Societal Concepts of Criminal Liability for Homicide in Mediaeval England," Speculum 47, no. 4 (1972), 686.

${ }^{10}$ Elizabeth Papp Kamali, "Felonia Felonice Facta: Felony and Intentionality in Medieval England," Criminal Law and Philosophy 9, no. 3 (2015).
} 
participating in the creation of what law and order meant. What people sought to achieve when using the law and courts can be difficult to ascertain, especially for the Middle Ages. For many, appealing in court was simply an extension of asking for help from friends and family in pursuit of righting a wrong. ${ }^{11}$ For others, appealing in court might have been an act of vengeance against a person for wrongs; a replacement for private violent retaliation. Still other people might not have worried about vengeance and instead looked at going to court as justice or even a rebalancing of the scales between two people or families. ${ }^{12}$ In this way, they also legitimized the courts themselves and the rule of law behind their establishment. However, going to law was not without some risk as the person accused of a wrong could then attempt vengeance upon their accuser. It was only after the ascension of the Plantagenets that a solution was found for this type of retaliation. ${ }^{13}$

Amid the confusion and loss of royal prestige as a result of a civil war, Henry II (r. 11541189) offered his people something they had been demanding for quite some time: more equitable justice. With the Constitutions of Clarendon in 1164 and the Assize of Clarendon in 1166, Henry II formally established the beginnings of the modern jury system. ${ }^{14}$ Having the courts and juries available changed the way people achieved vengeance; these juries allowed people of lesser means to accuse those higher up on the social and economic ladder without fear of retaliation. While many found these new avenues and procedures advantageous for pursuing wrongs, it also meant that private personal vengeance carried new risks from the courts.

\footnotetext{
${ }^{11}$ Appeal here is used in the sense of accusing someone of a wrongdoing.

12 William Ian Miller explores these ideas of vengeance and justice and balancing of scales in his self-described philosophical meditation on pay back. As he describes it, "peace that does not involve evening up scores and restoring the balance is not peace among equals." William Ian Miller, Eye for an Eye (Cambridge: Cambridge University Press, 2005), 15.

${ }^{13}$ John Hudson, The Formation of English Common Law: Law and Society in England From the Norman Conquest to Magna Carta (New York: Addison Wesley Longman, Ltd, 1996), 128-34.

${ }^{14}$ Even enacting these was a process of negotiation. See Hudson, The Formation of English Common Law, 129-31.
} 
Considered from this vantage point, Henry II's changes were less about him asserting royal authority and more about him opening up his authority to be used by his subjects. This is not to say that Henry II was not trying to expand his authority, rather that he did not force it; instead, he used the people's wants to bolster royal power. He put the tools, the courts and juries, in place and let the people use them for their own benefit. The people, by using his courts, completed the legitimization of his authority.

In the centuries between Henry II (r. 1154-1189) and Henry IV (r. 1399-1413), violence seemed to be permissible to individual subjects under fewer circumstances than earlier. ${ }^{15}$ People who employed violence in interpersonal conflicts in fifteenth-century England did so knowing that it might lead to legal action. ${ }^{16}$ This knowledge was part of the socialization process, much of which would have stemmed from family and neighbors. ${ }^{17}$ However, some of it also came from the visibility of the courts. People who more often engaged in court battles, perhaps those in trade or who owned property, would have been more aware of these risks of using violence and of going to court. All public courts were performative in nature, including the Court of Common Pleas which was one of England's central common law courts. While Londoners had easier access to this court, most Londoners would have seen changes in how interpersonal violence was treated through the city courts. These changes, both in how people used the courts and also in the laws in place, reflected the negotiation between the people and the crown over what constituted law and order and who was responsible for maintaining it. Although as Creyk v. Capon, the case which opened this chapter, illustrates, the distinctions had not been clearly delineated by the

\footnotetext{
${ }^{15}$ Hyams, Rancor \& Reconciliation in Medieval England, 249-50; Hudson, The Formation of English Common Law, 207.

${ }^{16}$ Warren C Brown, Violence in Medieval Europe (Harlow, UK: Pearson Education Limited, 2011), 213; Philippa C. Maddern, Violence and Social Order: East Anglia 1422-1442 (Oxford: Oxford University Press, 1992), 31-33.

${ }^{17}$ Hannah Skoda, Medieval Violence: Physical Brutality in Northern France, 1270-1330 (Oxford: Oxford University Press, 2013), 3, 18-19.
} 
early fifteenth century. Capon made an argument that he was acting on the side of the law while attempting to compel the appearance of someone in another court, while Creyk argued that acting on behalf of the law did not make Capon's violent actions lawful.

Part of the challenge with explaining the evolution of law in relation to violence, as well as the expanding central judicial system, in this way is that it makes it seem like an inevitable march of events towards a forgone conclusion of state-controlled violence. Yet this teleological view is false; as Chris Wickham shows, this view "presupposes and furthers an ideological statement about the superior legitimacy of royal power." ${ }^{18}$ Litigants using a central court does not mean that the litigants necessarily viewed their use as signifying royal superiority to other courts. Instead, as I argue in the following pages, plaintiffs used this court as one tool out of a plethora of tools available to them in resolving their disputes. London litigants often used a variety of approaches (city and central courts, arbitration, and societal pressures) in tandem with one another rather than to the exclusion of one another. ${ }^{19}$

I would like to pause here to offer a little more on the political background of England and London in order to provide a fuller context for the worlds in which these litigants operated. Overall, the fourteenth and fifteenth centuries were chaotic for England. Within four years of Richard II (r. 1377-1399) ascending the throne, he faced his first major crises, the Peasants' Revolt of 1381: an event that Anthony Musson sees as reflecting the rise of a 'legal consciousness' beginning from the Magna Carta in $1215 .{ }^{20}$ This sentiment is echoed by Caroline Barron in her history of late medieval London. In it, she suggests that part of the impetus behind

\footnotetext{
${ }^{18}$ Wickham, Courts and Conflict in Twelfth-Century Tuscany, 7.

19 This is similar to Wickham's findings for Tuscany in that multiple options available to a disputant helps illustrate the strategies used by litigants to achieve their end goals. Courts and Conflict in Twelfth-Century Tuscany, 8.

${ }^{20}$ Anthony Musson, Medieval Law in Context: The Growth of Legal Consciousness from Magna Carta to the Peasants' Revolt (Manchester: Manchester University Press, 2001), 1.
} 
the rebellion was dissatisfaction over court delays. ${ }^{21}$ During the intervening years, 1392 to 1397 , Richard II and London continued to have disagreements, perhaps about some Londoners joining in the 1381 revolt. $^{22}$ About ten years into Richard II's reign, five noblemen appealed the king's ministers for treason; it was Richard's reaction to this event that opened the door for his deposition. ${ }^{23}$ Richard banished Henry Bolingbroke, soon-to-be Duke of Lancaster, for his part in the rebellion and began dismantling the duchy. This act prompted Bolingbroke to return to England to lay claim to his rightful inheritance. ${ }^{24}$

While Bolingbroke may not have set out from France to depose his king, in the end, this was what happened. Henry was crowned king of England on October 13, 1399, becoming Henry IV, the first of the three in the Lancaster royal house. London sided with Bolingbroke during this usurpation, not altogether a surprise considering Richard's treatment of the autonomy of London and Londoners. Henry IV (r. 1399-1413) lost no time strengthening his position. ${ }^{25}$ Lancastrian rule saw fairly constant warfare in the first few years of Henry IV's reign with the Barons' Rebellion, Welsh Rebellion, and Percy Rebellions. ${ }^{26}$ Defeating these rebellions helped solidify not only his position on the throne, but also that of his heirs. Henry, prince of Wales, was on hand to assume power when the fifty-five-year-old Henry IV died on March 20, 1413. Henry V was crowned on April 9, 1413 and wasted no time in asserting his power. There were no major challenges to his right to the throne and he set about reducing the debt of the crown and healing

\footnotetext{
${ }^{21}$ Caroline M. Barron, London in the Later Middle Ages: Government and People, 1200-1500 (Oxford: Oxford University Press, 2004), 155. She gives a more detailed account of this rebellion in Caroline M. Barron, Revolt in London: 11th to 15th June 1381 (London: Museum of London, 1981).

${ }_{22}^{2}$ Barron, London in the Later Middle Ages, 13. See, also, Caroline M. Barron, "The Quarrel of Richard II with London, 1392-7," in Medieval London: Collected Papers of Caroline M. Barron, ed. Martha Carlin, and Joel T. Rosenthal (Kalamazoo, MI: Medieval Institute Publications, 2017).

${ }^{23}$ For a detailed account of the so-called Appellant's Rebellion and its aftermath, see Chris Given-Wilson, Henry IV (New Haven: Yale University Press, 2016), 41-60, 116-137.

${ }^{24}$ Given-Wilson, Henry IV, 121-22.

${ }^{25}$ Given-Wilson, Henry IV, 146-54.

${ }^{26}$ See Part Two of Given-Wilson's study for detailed examination of the embattled first six years of Henry's reign. Henry IV, 157-277.
} 
old wounds; he had Richard II reburied properly and reinstated many of those who sided against his father during that conflict. ${ }^{27}$ By the end of his first year as king, Henry V (r. 1413-1422) turned his attention to ensuring good governance in his kingdom. A dispute between the Earl of Arundel, a newly appointed government official, and John Talbot, Lord Furnival, a long-standing member of Henry's household helped prompt this shift in focus. Henry V used this dispute, the subsequent rebuke of both men, and the indictment of their retainers as a show that stature and ties to the king's household did not make one immune to justice. ${ }^{28}$ By the end of 1414 , Henry V's mind had turned to war with France; he wanted to restore the Angevin empire, as well as reassert his claims to the French throne.

These were volatile times for England, however, as Barron points out, London did not always follow these trends of violence. ${ }^{29}$ More often than not, the crown only interfered with the affairs and privileges of Londoners when it was plagued by what they perceived to be endemic lawlessness. Citizens had already garnered the disapproval of Richard II by siding against him during the two major challenges to his authority mentioned above. While the true reasons behind Richard II's decision were never revealed he revoked London's privileges during the summer of 1392. Barron offers a variety of possible reasons, from civil unrest caused by John Walpole beginning in 1388 to offensive smells coming from the butchers' quarter of the city. ${ }^{30}$ Although she also explains that it could be a result of a dispute of the administration of law within the city limits. ${ }^{31}$ This revocation of privileges at the hands of Richard II may be why Londoners were cautious, but ultimately accepting of Henry IV. ${ }^{32}$ As Barbara Hanawalt says, "by the fifteenth

\footnotetext{
27 A. J. Pollard, Late Medieval England, 1399-1509 (Harlow, UK: Pearson Education Limited, 2000 ), 70.

${ }^{28}$ Pollard, Late Medieval England, 71.

${ }^{29}$ Barron, London in the Later Middle Ages, 4-5. This sentiment is echoed by Steven Rappaport in Worlds Within Worlds: Structures of Life in Sixteenth-Century London (Cambridge: Cambridge University Press, 2002 ), 20.

${ }^{30}$ Barron, "The Quarrel of Richard II with London, 1392-7," 28.

${ }^{31}$ Barron, "The Quarrel of Richard II with London, 1392-7," 29-30.

32 Barbara A. Hanawalt, Ceremony and Civility: Civic Culture in Late Medieval London (Oxford: Oxford University
} 
century, the mayor and aldermen were more interested in maintaining stability in the city than

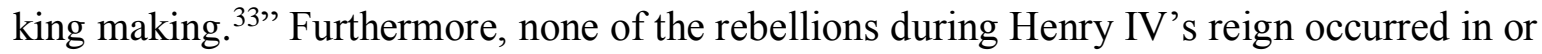
around London. As for Henry V, as long as he received money, he was content to let London be. While the depredations of national politics may have cost Londoners more in taxes, the violence that occurred along with these events were largely removed from the city.

\section{Historiography}

The historiography on violence in the Middle Ages is vast and can be divided into a number of subfields: violence and feudalism, violence and state formation, violence and persecution, and interpersonal violence, to name a few. ${ }^{34}$ It is this last subfield on violence to which this dissertation contributes. Most historians who study violence seek to answer broad, sweeping questions like how violent were the Middle Ages? What social norms governed the use of violence? What was the relationship between violence and order? These are important questions and the studies that come from answering them show that medieval people thought about and employed violence in highly sophisticated ways. According to Warren Brown, the Middle Ages were not any more violent than modern society. In his book, Violence in Medieval Europe, Brown argues that the violence in the Middle Ages was merely different, not greater. ${ }^{35}$

Press, 2017), 46-47.

${ }^{33}$ Hanawalt, Ceremony and Civility, 47.

${ }^{34}$ Of course, there will be some overlap between these subfields as singling out any one area and ignoring the others does a grave disservice to the intricacies of life, in the Middle Ages or any era.

${ }^{35}$ Brown, Violence in Medieval Europe, 5. This conclusion is also echoed by Matthew Gabriele, "Why the Middle Ages Wasn't More Violent Than the Modern World (Despite What 'Game of Thrones' Says)." Forbes.com (2018): accessed May 17, 2019, https://www.forbes.com/sites/matthewgabriele/2018/11/28/middle-ages-notmurder/\#76af72416bfc. While this work by Brown is considered a tertiary work, it builds off of his own previous work on conflict, as well as including extensive primary source research. See, for example, the two chapters he contributes to Warren C Brown, and Piotr Górecki, eds. Conflict in Medieval Europe: Changing Perspectives on Society and Culture (Farnham, UK: Ashgate Publishing, 2003). and his articles Warren C Brown, "The Use of Norms in Disputes in Early Medieval Bavaria," Viator 30 (1999); Warren C Brown, "Charters as Weapons: On the Role Played by Early Medieval Dispute Records in the Disputes They Record," Journal of Medieval History 28, no. 3 (2002). 
Both he and Hannah Skoda also examine the ways in which violence was considered either legitimate or illegitimate. Brown posits that it was the people in power, to a greater extent, who decided whether violence was licit or not. He sees violence as an issue of power and legitimacy, whether employed at an interpersonal level or during larger power struggles between monarchs. However, Skoda in her book, Medieval Violence, argues that violence was socially constructed and that the people helped decide what interpersonal violence was legitimate. ${ }^{36}$ Neither historian focuses on military or judicial violence, but rather examines the societal norms governing the use of violence in conflicts.

In doing so, they each also examine how those societal norms changed over time, in the case of Brown, or are dependent on time period and location, in the case of Skoda. Brown weaves a narrative throughout his book of medieval rulers seeking to control violence within their realms. He traces over time, roughly between the twelfth and fifteenth centuries, how kings across Europe were able to implement restrictions on private vengeance, with varying degrees of success, thereby instilling order in their kingdoms. Skoda, on the other hand, limits herself to a sixty-year time period and a geographic area of Paris and Artois in northern France. She also argues that violence, even interpersonal violence, was seen as a threat to public order if used improperly. In a conclusion similar to Brown, Skoda found that "while the raison d'être of law was apparently to establish the rightful ordering of society, the violence which legal mechanisms attempted to stem claimed to fulfil a very similar function." 37

When analyzing interpersonal violence in the Middle Ages and early modern period, scholars tend to focus on misdemeanors or felonies, or what we call crime in modern legal terms,

\footnotetext{
${ }^{36}$ Skoda, Medieval Violence, 3.

${ }^{37}$ Skoda, Medieval Violence, 55.
} 
rather than civil actions. ${ }^{38}$ Both the language and definitions of late medieval legal records can be difficult to pin down. Often what we call a misdemeanor in modern law would be called a trespass in the Middle Ages. For ease of understanding, I use trespass for personal actions which used civil proceedings and misdemeanor and felony for anything that used criminal proceedings. At its core, the main difference between a misdemeanor and a felony was the risk of death and property loss, which could happen with a felony, but not a misdemeanor. ${ }^{39}$ In some ways, this emphasis on felonies and criminal proceedings is understandable. Of the thousands of cases entered onto the plea rolls of the Court of Common Pleas, the majority of them dealt with debt and other economic disputes. Those particular cases do not pertain to violence in any way. Within these records, nevertheless, are hundreds of cases pertaining to violent torts, ${ }^{40}$ classified under the action of trespass vi et armis. ${ }^{41}$ This action covered an array of violent acts, some more evidently so than others, e.g. assault versus the taking of goods. The argument that not all violence was disorderly is echoed in some of the defendants' pleas in the records of the Court of Common Pleas examined in this dissertation. The plaintiffs in these cases claim the defendants used illicit violence against them or someone under their care, while in many instances the

\footnotetext{
${ }^{38}$ See, among others, J.G. Bellamy, Criminal Law and Society in Late Medieval and Tudor England (New York: St. Martin's Press, 1984); Bellamy, The Criminal Trial in Later Medieval England; Jenny Benham, "Wounding in the High Middle Ages: Law and Practice," in The History of Medicine in Context: Wounds in the Middle Ages, ed. Anne Kirkham, and Cordelia Warr (Farnham, UK: Ashgate Publishing, 2014); Manuel Eisner, "Long-Term Historical Trends in Violent Crime," Crime and Justice 30, no. 2003 (2003); Malcolm Gaskill, "Reporting Murder: Fiction in the Archives in Early Modern England," Social History 23, no. 1 (1998); Green, "Societal Concepts of Criminal Liability"; Thomas A. Green, Verdict According to Conscience: Perspectives on the English Criminal Trial Jury, 1200-1800 (Chicago: University of Chicago Press, 1985); Barbara Hanawalt, and David Wallace, Medieval Crime and Social Control (Minneapolis: University of Minnesota Press, 1999); Karen Jones, Gender and Petty Crime in Late Medieval England (Woodbridge, UK: Boydell Press, 2006); Kamali, "Felonia Felonice Facta"; Anthony J. Musson, "Turning King's Evidence: the Prosecution of Crime in Late Medieval England," Oxford Journal of Legal Studies 19, no. 3 (1999). I will discuss those scholars who engage with the Court of Common Pleas records below. ${ }^{39}$ Kamali, "Felonia Felonice Facta," 403. I discuss this in more detail in chapters two and four.

${ }^{40}$ A tort is a wrongful act.

${ }^{41}$ The Medieval English system of law distinguished between a variety of person to person civil actions, of which trespass was but one. I explain in more detail the various torts under the umbrella of trespass vi et armis in chapter two.
} 
defendants argued that the violence they used was licit because it was merely restoring order. These cases, and the arguments of Skoda and Brown, together reflect the process of negotiation over licit and illicit violence.

Richard Kaeuper contributes to this debate on violence and public order in his book, Chivalry and Violence in Medieval Europe..$^{42}$ Focusing almost solely on knights, he examines the link between chivalry, violence, and public order. Kaeuper argues that the knights were problematic, as were their chivalric ideals, and did just as much to hinder order as they did to contribute to it. Much like Brown and Skoda, he touches on the big question of the nature of violence in the Middle Ages. He also examines how and when society started to question violent vengeance as a licit form of violence. Chivalry and its demands for knights to resort to violence for the merest provocation against their honor often led men into actions that were condemned by rulers and the courts. ${ }^{43}$ The discrepancy between chivalric culture and judicial solutions faced by these men is similar to what Shannon McSheffrey points out in her article, "The Slaying of Sir William Pennington: Legal Narrative and the Late Medieval English Archive." ${ }^{\prime 4}$ In this article, she examines the various layers of context that go into creating and understanding a legal narrative. Of particular interest here is where she discusses tensions between aristocratic masculinity and self-defense narratives in the case of a felony homicide. Aristocratic culture would call the traditional narrative of self-defense used in felony cases cowardly as one was required to flee rather than stand and fight. ${ }^{45}$

By drawing on cases from the Court of Common Pleas, I add to these discussions about

\footnotetext{
${ }^{42}$ Richard Kaeuper, Chivalry and Violence in Medieval Europe (Oxford: Oxford University Press, 1999).

${ }^{43}$ Kaeuper, Chivalry and Violence in Medieval Europe, 96-97.

${ }^{44}$ Shannon McSheffrey, "The Slaying of Sir William Pennington: Legal Narrative and the Late Medieval English Archive," Florilegium 28 (2011).

${ }^{45}$ McSheffrey, "The Slaying of Sir William Pennington," 185-86.
} 
how medieval people both conceptualized and possibly experienced medieval violence, whether physical or not. These cases and the litigants participating in them show that societal norms governing violence did not vary between criminal and civil proceedings. However, they also illustrate that many of these norms crossed boundaries of social hierarchies. Kaeuper himself points out that in England at least, wealthier 'peasants' also read chivalric literature and adopted its ideals. ${ }^{46}$ Perhaps it is not surprising, therefore, to find cases in the Court of Common Pleas in which non-gentry Englishmen express the ideals of violence in defense of honor and reputation found in the chivalric ideology. While there were a few individuals in my sample set of data with land and titles to their names, more knights or landed gentry, the majority of the men and women who appeared before the Court of Common Pleas either had no status or occupation designated or were listed as tradesmen or craftsmen of some kind. ${ }^{47}$ Regardless of status or occupation, they used societal norms about honor and reputation, as a plaintiff in going to court and as a defendant in justifying their actions. As a public performance, the courtroom offered a way to publicly restore reputation, or to publicly lose it.

Some historians argue that honor or reputation was not the main underlying issue to the violence seen in court records. Philippa Maddern, in Violence and Social Order, argues that violence was used by the gentry, nobility, and the crown to reinforce social order. ${ }^{48}$ She further states that not only did the men and women of high social status use violence, but it was an ingrained part of their lives. Similar to M.W. McHaffie, Maddern does not see violence as a symptom of disorder, but rather of the instillation of that order. In his article, "Law and Violence in Eleventh-Century France," McHaffie argues that violence was a tool for making claims on

\footnotetext{
${ }^{46}$ Kaeuper, Chivalry and Violence in Medieval Europe, 112-14.

${ }^{47}$ See Table 7 on page 222 for a breakdown of all litigants by status, occupation, and gender.

${ }^{48}$ Maddern, Violence and Social Order, 228.
} 
land and that the claims of violence in courts were the result of the patronage system in twelfthcentury feudal France. The core issue for France's legal institutes then, according to McHaffie, was not the violence but the land dispute. This echoes Maddern's conclusion that "even allegations of assault, and other violence against a person, might be used simply to further the litigants' pursuit of property rights, rather than to signify the occurrence of actual violence."49 The point here is not to contest Maddern's conclusions, but rather suggest that reorienting the focus away from why the violence, or allegation thereof, might have occurred towards how violence was described and handled by the court procedures is an alternative way of examining court records. Maddern's source base relies almost solely on criminal proceedings though, citing a plethora of gaol deliveries and cases before the Court of the King's Bench. She only uses two plea rolls from the Court of Common Pleas. ${ }^{50}$

Vi et armis, which means "with force and arms," was a formulaic phrase used in a variety of court records and most historians do not take the accusations at face value. Indeed, they often argue that medieval people did not even take the accusations in this type of action at face value. For example, when S.F.C. Milsom discusses trespass vi et armis he uses a case in which a plaintiff accused the defendant of stealing wine from a barrel (which had been left in the defendant's keeping) with swords, staves, and knives. ${ }^{51}$ The idea, then, was that individuals involved in the court case did not think the allegations were truthful. Louise Harmon points out, by explanation, that plaintiffs used legal fictions, such as trespass vi et armis, because "it mattered which court settled the dispute." 52 In other words, to the plaintiff and courts what was at

\footnotetext{
${ }^{49}$ Maddern, Violence and Social Order, 47.

${ }^{50}$ Maddern, Violence and Social Order, 255.

${ }^{51}$ S.F.C. Milsom, Studies in the History of the Common Law (London: Hambledon Press, 1985), 155. There is no indication in Milsom's work whether this case went before the Court of Common Pleas or the Court of the King's Bench; however, most year books, which was Milsom's source, contain Court of Common Pleas records.

${ }^{52}$ Louise Harmon, "Falling off the Vine: Legal Fictions and the Doctrine of Substituted Judgment," Yale Law Journal 100, no. 1 (1990), 6.
} 
dispute was less relevant than who had jurisdiction over it. Harmon's article provides an overview of the debates, mostly modern, surrounding the use of legal fictions in court actions, although she does devote a small section to William Blackstone and his views on the usefulness of the "notorious fictional trespass "vi et armis'."53 According to Blackstone, trespass vi et armis was mostly used to bring a false allegation before the Court of the King's Bench in order for the plaintiff to then sue in that court for a wrong that normally would not be under the purview of the court; they would subsequently default on the trespass vi et armis as the defendant had never committed that alleged wrong. ${ }^{54}$ While Blackstone wrote his commentaries on the laws of England in the eighteenth century, the mechanisms of law move slowly so one can see these same machinations at work in the fifteenth and sixteenth centuries.

However, using the action of trespass vi et armis to get a case before the Court of the King's Bench had some risks; most obvious would be that the case was assigned to either the Court of the King's Bench or the Court of Common Pleas out of the Court of Chancery. Before 1450 , most of the cases went to the Court of Common Pleas. ${ }^{55}$ Savvy litigants and lawyers were not to be deterred and this gave rise to the most popular legal fiction of the fifteenth century: the Bill of Middlesex. Much of Margaret Blatcher's book on the Court of the King's Bench is devoted to the formulation of the Bill of Middlesex, which achieved a similar end of getting a defendant in front of that court. ${ }^{56}$ The Bill of Middlesex was developed during the fifteenth century, beginning around 1421. This was a legal fiction designed to force the appearance of a defendant from another part of the country. Using this bill, a plaintiff alleged that the defendant

\footnotetext{
${ }^{53}$ Harmon, "Falling off the Vine," 6.

${ }^{54}$ Sir William Blackstone, Commentaries on the Laws of England: Book the Third (London: Dawsons of Pall Mall, 1966), 43. Default means the plaintiff ceased appearing in court in pursuit of the case. This usually resulted in a fine for the plaintiff, payable to the crown.

${ }^{55}$ Margaret Hastings, The Court of Common Pleas in Fifteenth Century England: A Study of Legal Administration and Procedure (Ithaca: Cornell University Press, 1947), 19.

${ }^{56}$ Marjorie Blatcher, The Court of King's Bench, 1450-1550: A Study in Self-Help (London: Athlone Press, 1978).
} 
was imprisoned at Marshalsea, the prison of the Court of the King's Bench, thereby giving it jurisdiction and avoiding the long process of moving through a local court. ${ }^{57}$ While the Bill of Middlesex was a later development, it is illustrative of the evolution of litigant strategies to achieve their end goals. However, not all plaintiffs wanted to use the Court of the King's Bench; some sought out the Court of Common Pleas. Here too, individuals seemed to have used trespass vi et armis for strategic reasons. Penny Tucker shows that by the mid-thirteenth century people were fictitiously claiming violence in a trespass so that it could be heard before either of the central courts. ${ }^{58}$ Tucker provides examples of cases in which "plaintiffs may have been using exaggerated language in order to create a trespass out of some objectionable, but not necessarily unlawful official act." 59 This use of trespass vi et armis matches with the categorization by Milsom with his example of the wine theft.

Tucker is not the only historian to see cases with trespass vi et armis and interpret the plaintiffs as falsifying the nature of a wrongful act to make it seem worse than it was. Kaeuper also dismisses the phrase vi et armis as a useful tool for a plaintiff to get "cases that involved mere gentle fraud or illegal apple-picking" into a central court. ${ }^{60}$ Brown claims to see a similar pattern: he argues that if the accused had not committed a felony, or a jury would not have supported the appeal of a felony, then the victim "needed" to get creative in order to access royal justice. He then suggests that the creativeness of these plaintiffs led to the development of vi et armis as a charge which elevated a mere trespass to a royal concern. ${ }^{61}$ However, Brown seems to

\footnotetext{
${ }^{57}$ Cases had to be brought before the royal county courts where the trespass had occurred. Hastings, The Court of Common Pleas in the Fifteenth Century, 25; Euan Rogers, "The Court of Common Pleas," Postgraduate Archival Training (PAST): Medieval Legal Records Workshop, The National Archives (2018).

58 Penny Tucker, Law Courts and Lawyers in the City of London 1300-1550 (Cambridge Studies in English Legal History) (Cambridge: Cambridge University Press, 2007), 61. See also S.F.C. Milsom, Historical Foundations of the Common Law (London: Butterworths, 1981), who was one of the first historians to make this claim.

59 Tucker, Law Courts and Lawyers in London, 67.

${ }^{60}$ Kaeuper, Chivalry and Violence in Medieval Europe, 109.

${ }^{61}$ Brown, Violence in Medieval Europe, 207.
} 
falsely relate felonies and trespasses. According to George Woodbine, trespass vi et armis

developed out of a combination the assize of novel disseisin and the action of false imprisonment and "was from the first a civil action." ${ }^{\prime 2}$ Neither Kaeuper nor Brown are interested in examining Court of Common Pleas cases. Rather, they both focus on the conceptualization of violence on a societal level and so trespass actions made up only a tiny fraction of the evidence they use. However, overlooking these cases is problematic and misses a relatively large dataset of information about violence.

Other historians have similarly dismissed this writ as one that people used when they wanted to sue for other things. ${ }^{63}$ McHaffie, Maddern, and Janet Loengard suggest that plaintiffs used trespass vi et armis when violence occurred as a result of a dispute about other issues. ${ }^{64}$ While none of these historians automatically assumes that the use is a fiction, they also do not investigate how the individuals involved use the courts to their advantage, or what that violence meant to the people involved, but rather focus on the precipitating event in their analyses. ${ }^{65}$ Like Maddern and Loengard, Charles Pythian-Adams identifies the use of this writ with land disputes, going so far as to link them with the creation of the "wearisomely repetitive and hence suspiciously formalized formulation of the common law writ of trespass vi et armis." ${ }^{\prime 66}$ Whether

\footnotetext{
${ }^{62}$ George E Woodbine, “Origins of the Action of Trespass," Yale Law Journal 34, no. 4 (1925), 370.

${ }^{63}$ For example, in John Baker's extensive overview of English laws, he says nothing about it being a legal fiction, although he does comment on it as a formula and not much more. Formulaic phrases were used in almost all civil actions and might represent a fiction within the records, but a legal fiction was the use of the entire action for an alternative purpose. J.H. Baker, The Oxford History of the Laws of England, Vol. 6 (Oxford: Oxford University Press, 2003), 207.

${ }^{64}$ Janet Loengard, "What is a Nice (Thirteenth-Century) English Woman Doing in the King's Courts?," in The Ties that Bind: Essays in Medieval British History in Honor of Barbara Hanawalt, ed. Linda E. Mitchell, Katherine L. French, and Douglas L. Biggs (Farnham, UK: Ashgate Publishing, 2011); Maddern, Violence and Social Order. ${ }^{65}$ The example Loengard uses was a custody dispute that devolved to violence. For Maddern, the central focus was the land disputes between gentry.

${ }^{66}$ Charles Pythian-Adams, "Rituals of Personal Confrontation in Late Medieval England," Bulletin of the John Rylands Library 73, no. 1 (1991), 77. Susan Dwyer Amussen suggests (like Tucker) that people threw in the words whenever they felt someone had acted beyond what was acceptable by societal norms, but it did not necessarily mean they were violent. She, too, dismisses vi et armis as formulaic. Susan Dwyer Amussen, "Punishment, Discipline, and Power: The Social Meanings of Violence in Early Modern England," Journal of British Studies 34,
} 
the plaintiffs lied about the violence done to them or used the issue of violence to further a different agenda is immaterial. As McSheffrey points out, the plaintiffs still had to create a believable series of events in order for a court to issue the writ. ${ }^{67}$ The circumstances of the alleged act of violence also had to be believable to both the courtroom personnel and to potential jurors. Perhaps this was less of a necessity if everyone involved in the case knew it was being used as a legal fiction, but it would be almost impossible for a historian to differentiate "real" cases from fictionalized ones. While some historians choose to err on the side of fiction as a result of this, having ascertained that some of these cases do involve confirmed instances of violence, I approach each case, whether made in bad or good faith, as a way to investigate how Londoners used the courts. Trespass vi et armis cases illustrate that plaintiffs and defendants consciously pursued their own interests, provide examples of people's conceptions of violence, and further allow for the examination of defenses that illustrate the negotiation over licit and illicit violence. Dismissing these cases means losing a valuable source of evidence in reconstructing how people conceptualized violence and used the legal system to their advantage.

Historians have examined women and men before the courts in a number of ways, although early legal history did not usually focus on women. ${ }^{68}$ There are a variety of reasons for this. Women did not appear in court records as often as men and, therefore, if one only measures female criminality against male, women are already marginalized. Women, statistically speaking, were more often victims, but legal restrictions of the time, like coverture, also made it more difficult for them to appear in court records. For example, in this study, of the 235 litigants (either plaintiff or defendant) between 1405 and 1415, only twenty-eight were women (just under

\footnotetext{
no. 1 (1995), 3.

${ }^{67}$ McSheffrey, "The Slaying of Sir William Pennington," 171.

${ }^{68}$ I explore these historians, in particular, in chapter two where I examine the evolution of the legal systems of England.
} 
twelve percent). ${ }^{69}$ Early twentieth-century methodologies, especially statistical analysis and their choice of sources, do not allow for a plethora of female plaintiffs or defendants. For example, in Frederic Maitland and Frederick Pollock's seminal work, women are discussed on less than forty out of over 670 pages; in Theodore Plucknett's history of the common law, he discusses women roughly thirty-five times in around 700 pages of text. ${ }^{70}$ However, as social and gender history expanded in the 1980s and 1990s historians developed other methods in order to better understand women's roles in interactions with the legal system.

In the last thirty years, historians began to focus on women or gender in their coverage of crime or law. For example, Trevor Dean includes a chapter on women and crime in his general overview, Crime in Medieval Europe. ${ }^{71}$ While this is a tertiary source, Dean's conclusions that gender affected women's experiences in court are reinforced in other scholarship. Krista Kesselring illustrates a similar idea in her article on gender and homicide. Kesselring concludes that between 1500 and 1680 English concepts of the nature of men and women "mapped onto differences between men's and women's homicidal behavior."72 Women, cold-blooded by nature, were accused more often of premeditated or especially heinous killings, while men, hotblooded by nature, were more often accused of killing in the moment. ${ }^{73}$ In this way, the charges against men were often defensible, while charges against women were not. Dean finds that women were treated more leniently as offenders in criminal proceedings, a conclusion that is

\footnotetext{
${ }^{69}$ In the larger dataset, covering the fifteenth century, used in chapter five, there were 2708 defendants, of which 248 were women (just over nine percent). See Table 7 on page 222 for a visual representation of this.

${ }^{70}$ Sir Frederick Pollock, and Frederic William Maitland, The History of English Law Before the Time of Edward I (Cambridge: Cambridge University Press, 1895); Theodore Frank Thomas Plucknett, A Concise History of the Common Law (Rochester, NY: The Lawyers Co-Operative Publishing Company, 1929).

${ }^{71}$ Trevor Dean, Crime in Medieval Europe: 1200-1550 (Harlow, UK: Longman, 2001), 73-117.

${ }^{72}$ Krista J Kesselring, "Bodies of Evidence: Sex and Murder (or Gender and Homicide) in Early Modern England, c. 1500-1680," Gender \& History 27, no. 2 (2015), 246.

${ }^{73}$ Kesselring, "Bodies of Evidence," 253.
} 
both problematized and supported by Kesselring's data. ${ }^{74}$ She does concede that women, for minor offenses, might be convicted of a lesser charge as a result of societal ideas about gender and culpability, although the same standard did not necessarily apply to instances of homicide. ${ }^{75}$ Unfortunately my evidence cannot support or refute a similar conclusion for civil actions because of the lack of resolution in the majority of records for the Court of Common Pleas; however, my data does show that violent actions which involved women were valued less than those which only involved men. Women were involved in many more types of criminal acts than Dean had the time or space to discuss in his chapter, but he does draw from some of the preeminent historians who discuss a wider array of female criminality and who occupy the overlapping space of women, crime, and legal studies.

Other historians have more directly examined the extent to which legal structures have controlled the behaviors of women. The authors discussed in the following pages have all influenced my examination of violent torts through their emphasis on the use of law in the Middle Ages to regulate behavior. Although they mostly focus on criminal actions rather than civil actions, they analyze how laws and courts were used to educate society about accepted norms of behavior, which has similarly influenced my study. In Common Women, for example, Ruth Mazo Karras considers the role social norms played in understanding medieval prostitution. ${ }^{76}$ Karras argues that the real issue behind the regulation of prostitution was social control of the promiscuous behavior of women; single women were especially vulnerable to the label of whore because they were not under the authority, and subsequently protection, of a man. Sandy Bardsley similarly influences this study with her complex gender analysis of legal records

\footnotetext{
${ }^{74}$ Dean, Crime in Medieval Europe, 78.

${ }^{75}$ Kesselring, "Bodies of Evidence," 252.

${ }^{76}$ Ruth Mazo Karras, Common Women: Prostitution and Sexuality in Medieval England (Oxford: Oxford University Press, 1996).
} 
in her book, Venomous Tongues. She shows that during the late medieval period control over speech, especially that of women, increased. Bardsley attributes this increase in enforcement of women's speech to the social and economic upheaval that followed the Black Death; in essence, in the aftermath of the crisis men sought to control and enforce gendered behavior of women in an attempt to reassert power. In the cases I examine, some instances of violence appear, in part, as attempts to control women or reassert power. For example, in the case of Agnes Carpenter in Carpenter v. Dygon, one interpretation of the events leading to his alleged assault of her could be that she stepped too far beyond what John Dygon considered acceptable behavior. ${ }^{77}$

In other cases, a lawsuit may have been brought to restore a tarnished reputation, sexual or otherwise. Teresa Phipps examines concepts of women and reputation in her article, "Misbehaving Women." She explores trespass actions across three towns in England over the course of the fourteenth century and argues that "trespass litigation enabled women to defend and claim their honor through local courts. ${ }^{" 78}$ However, she did not find any gendered difference in the types of complaints, nor in the language used in them. Cases involving women did not focus on sexual reputation or sexual insults, which led Phipps to conclude that men and women emphasized economic reputation when using trespass litigation. ${ }^{79}$ Marjorie McIntosh also focuses on reputation and social control of behavior in her book, Controlling Misbehavior. This is an examination of long-term trends between 1370 and 1600; however, unlike Phipps, McIntosh limits her study to mostly non-violent actions, such as excessive drinking or sexual promiscuity. ${ }^{80}$ While Phipps uses the local equivalent of the Court of Common Pleas, McIntosh

\footnotetext{
77 TNA, CP 40/594, rot. 135. This case will be discussed in more detail in chapter four.

${ }^{78}$ The towns are Nottingham, Chester, and Winchester. Teresa Phipps, "Misbehaving Women: Trespass and Honor in Late Medieval English Towns," Historical Reflections 43, no. 1 (2017), 67.

${ }^{79}$ Phipps, "Misbehaving Women," 72.

${ }^{80}$ Marjorie Keniston McIntosh, Controlling Misbehavior in England, 1370-1600 (Cambridge: Cambridge University Press, 1998), 4.
} 
uses church courts and courts using criminal procedures. McIntosh finds that concerns over misbehavior increased between the fourteenth and seventeenth centuries, although there were variations based on location on what actions most concerned the men of presentment juries, women's sexual behavior still dominated. ${ }^{81}$ This is similar to the conclusions that Karen Jones' comes to in her book, Gender and Petty Crime in Late Medieval England. Like McIntosh, Jones uses a mixture of secular courts and church courts in her examination of misdemeanors and how these both reflect and influence gender over the course of the late fifteenth and early sixteenth centuries. ${ }^{82}$ She does not find that women were treated more leniently, as Dean suggested, but the cases she examines reinforces the idea that a woman's sexual reputation was easily lost.

While many women may have needed to pay extra attention to their sexual reputation, Caroline Dunn argues that they were not without recourse if something happened to damage it in her book, Stolen Women in Medieval England. ${ }^{83}$ She examines instances of rape, adultery, and abduction during the high and late Middle Ages, and although women could be victims of these violent acts, she shows that women eloped or arranged their own abductions as a way to exert some control over their marriages and sexual lives despite, or perhaps to spite, male regulation and victimization. There are several cases in this dissertation which might have resulted from the desire to restore a tarnished reputation after just such expressions of self-autonomy. ${ }^{84}$ Dunn uses a myriad of court records for her book and includes about twenty-five cases from the Court of Common Pleas. Throughout the records, she notes that vocabulary changed over time, such as the definition of rapere, which in the 1100 s meant stolen but by the 1500 s meant sexual assault.

\footnotetext{
${ }^{81}$ McIntosh, Controlling Misbehavior, 214.

82 Jones, Gender and Petty Crime in Late Medieval England, 197-98.

${ }^{83}$ Caroline Dunn, Stolen Women in Medieval England: Rape, Abduction, and Adultery, 1100-1500 (Cambridge: Cambridge University Press, 2012).

${ }^{84}$ Two prominent ones that will be discussed in detail below are Swyft v. Pope in which Petronilla Swyft sued John Pope of imprisoning her for half a day; and Swepston v. Bargon in which Robert Swepston and his wife Joan accused John Bargon of keeping Joan prisoner for two days. TNA, CP 40/598, rot. 345; TNA, CP 40/602, rot. 171d.
} 
Court records, as Dunn points out, are constructed narratives, which are then further restricted by legal conventions. For the abduction cases that Dunn examined, writs used rapuit et abduxit regardless of how the people involved may have described the crime. The terminology in the records, Dunn argues, reinforces the notion of women as property by conflating their person with the actual property and inheritance rights that went with them. Perhaps most influential to this study, Dunn's use of the Court of Common Pleas cases shows that information about gender expectations can be gleaned from these highly formulaic records.

The works by Karras, Bardsley, McIntosh, and Dunn all concentrate on the use of medieval law and legal structures to control women's behaviors or some aspect of it. They either examine women engaging in actions socially gendered as female, such as scolding or prostitution, or women as victims, as with rape and abduction. Other historians have approached women and the law with women as the perpetrators. In "Theft and Gender in Late Medieval Bologna," Trevor Dean argues that women were not economically marginalized in the late medieval period. ${ }^{85}$ Women may have stolen items of less value than men did and they may have stolen closer to, or from, the home because of the accepted gendered behavior of the time, but he disputes the idea that only poverty-stricken women were driven to steal. Garthine Walker's work on the early modern period complements Dean's; she argues that women's economic activity ranged farther than the guild work that preoccupied many men. ${ }^{86}$ Walker asserts that women's criminality stretched beyond the court systems to fencing and the recovery of stolen goods. She urges historians to use gender as an analytical tool, but also to look beyond the male-dominated

\footnotetext{
85 Trevor Dean, "Theft and Gender in Late Medieval Bologna," Gender \& History 20, no. 2 (2008).

${ }^{86}$ Garthine Walker, "Women, Theft and the World of Stolen Goods," in Women, Crime and the Courts in Early Modern England, ed. Jennifer Kermode, and Garthine Walker (Chapel Hill: University of North Carolina Press, 1994).
} 
world of crime and punishment. ${ }^{87}$ Both Dean and Walker examine one small facet of female criminality, theft, in disparate locations and times. In her book, Crime, Gender and Social Order in Early Modern England, Walker extends her analysis beyond theft, showing that women who had been convicted of murder, especially of their husbands, and women who had been convicted of theft in the early modern period were less likely to receive leniency due to their gender, a conclusion reinforced by Kesselring's examination of homicide. ${ }^{88}$ Walker devotes an entire chapter to gender and homicide this book, showing that comparing women's sentences to men's sentences is a problematic venture. ${ }^{89}$ As Kesselring and Walker both show, the murders that women were accused of were seen as more heinous by society and the courts. However, women were also less likely to be brought up on these charges in the first place, which reinforces notions of gendered behavior that suggested that women were less prone to violence than men. ${ }^{90}$ This is an interesting conclusion and one that the records of the Court of Common Pleas both support and refute. Women certainly do appear less frequently in the records and more women than men were involved in wrongs dealing with abduction, imprisonment, and theft, but nonetheless women were accused of assault and not just against other women. Some men, at least, had no compunction about admitting to being attacked by a woman in the records I explore below.

Examining gendered constructs of violence is something Jennine Hurl-Eamon does in her book, Gender and Petty Violence in London. ${ }^{91}$ Hurl-Eamon studies recognizances for assault in Westminster, defining assault as physical or verbal acts of aggression. A recognizance was an

\footnotetext{
${ }^{87}$ Walker, "Women, Theft and the World of Stolen Goods," 99.

${ }^{88}$ Garthine Walker, Crime, Gender and Social Order in Early Modern England (Cambridge: Cambridge University Press, 2003), 157-58.

${ }^{89}$ Garthine Walker, "Homicide, Gender, and Justice," in Crime, Gender and Social Order in Early Modern England (Cambridge: Cambridge University Press, 2003).

${ }^{90}$ Many scholars, like myself, have rejected this blanket statement of women being less violent, including Walker and Kesselring. Walker, "Homicide, Gender, and Justice," 158; Kesselring, "Bodies of Evidence," 252.

${ }^{91}$ Jennine Hurl-Eamon, Gender and Petty Violence in London, 1680-1720 (Columbus: Ohio State University Press, 2005).
} 
order for the offender to appear before the next court session to answer the complainant. Other than causing some financial penalty in terms of court costs and the time taken to appear before the courts, recognizances did not punish the offender. Recognizances offer a unique view, according to Hurl-Eamon, because violence was a regular part of early modern life, yet these acts of aggression pushed the boundaries of acceptable violence. ${ }^{92}$ However, the cost of a full prosecution was not warranted by these acts of violence. One of Hurl-Eamon's main arguments is that there was a power in victimhood and that recognizances allowed people of lesser power (women and men of lower social statuses) to litigate social superiors. For example, she argues that there was no risk to masculinity in a man accusing a woman of assault. ${ }^{93}$ She sets up acts of violence on a sliding scale of prosecution efforts, ranging from those that warranted the full force of the law all the way down to those that did not include legal officials at all. Maddern also examines this idea of a continuum of violence and litigation: law and order not as a dichotomy but as a spectrum. ${ }^{94}$ While my investigation into the records of the Court of Common Pleas supports some of these conclusions, that it was far from abnormal for a woman to engage in violence, for example, the records indicate more of a dichotomy between licit and illicit rather than a sliding scale between two ends of a spectrum.

This study contributes to the historiography of gender and law by exploiting an uncommon source of evidence, civil actions, to uncover instances of alleged violence and to explore their contexts. I also propose, through a selection of civil proceedings, to examine the ways that men and women used the courts for their own needs, whether that was deciding who owned a certain plot of land or to debate whether certain violence constituted a licit or illicit act.

\footnotetext{
92 Hurl-Eamon, Gender and Petty Violence in London, 2.

${ }^{93}$ Hurl-Eamon, Gender and Petty Violence in London, 24. This is a sentiment echoed by Phipps, "Misbehaving Women," 67.

${ }^{94}$ Maddern, Violence and Social Order, 14.
} 
The Court of Common Pleas and trespass vi et armis actions represent an untapped resource and offer a way to uncover how these machinations were 'performed' in open court. A number of scholars have used the Court of Common Pleas to study a variety of issues, including the structure and inner workings of the court. Michael T. Clanchy and Ralph Turner, for instance, both examine the origins of the Court of Common Pleas. ${ }^{95}$ Woodbine, while not discussing the Court of Common Pleas specifically, devotes two articles to examining how trespass vi et armis became an action unto itself. ${ }^{96}$ Margaret Hastings provides an excellent case study of the court in her book, The Court of Common Pleas in Fifteenth Century England. ${ }^{97}$ Clanchy and Turner provide overviews of how the court came into being, rather than focus on the cases heard. In her book, Hastings considers the structure of the court and provides a detailed overview of the personnel of the court and the procedures to bring an action. She also discusses the limitations of the court and how the procedures changed over the course of the fifteenth century.

Other historians have used the cases heard before the Court of Common Pleas for a variety of projects, some of which focus on women. Jonathan Mackman, Sue Sheridan Walker, and Matthew Frank Stevens are among these scholars. ${ }^{98}$ Using a variety of actions, from debt to

\footnotetext{
${ }_{95}$ Michael T Clanchy, "Magna Carta and the Common Pleas," in Studies in Medieval History Presented to R.H.C Davis, ed. R.H.C Davis, Henry Mayr-Harting, and R.I. Moore (London: Hambledon Press, 1985); Ralph V. Turner, "The Origins of Common Pleas and King's Bench," American Journal of Legal History 21, no. 3 (1977).

${ }^{96}$ George E Woodbine, "Origins of the Action of Trespass," Yale Law Journal 33, no. 8 (1924); Woodbine, "Origins of the Action of Trespass."

${ }^{97}$ Hastings, The Court of Common Pleas in the Fifteenth Century.

${ }^{98}$ Derek Keene, "Changes in London's Economic Hinterland as Indicated by Debt Cases in the Court of Common Pleas," in Trade, Urban Hinterlands and Market Integration, c 1300-1600, ed. James A. Galloway (London: Centre for Metropolitan History, 2000); Jonathan Mackman, "'Hidden Gems' in the Records of the Common Pleas: New Evidence on the Legacy of Lucy Visconti," in Rule, Redemption, and Representations in Late Medieval England and France, ed. Linda Clark (Woodbridge, UK: Boydell Press, 2008); Matthew Frank Stevens, "Failed Arbitrations before the Court of Common Pleas: Cases Relating to London and Londoners, 1400-1468," Journal of Legal History 31, no. 1 (2010); Matthew Frank Stevens, "London's Married Women, Debt Litigation and Coverture in the Court of Common Pleas," in Married Women and the Law in Premodern Northwest Europe, ed. Cordelia Beattie, and Matthew Frank Stevens (Woodbridge, UK: Boydell Press, 2013); Sue Sheridan Walker, "The Feudal Family and the Common Law Courts: The Pleas Protecting Rights of Wardship and Marriage, c. 1225-1375," Journal of Medieval History 14, no. 1 (1988). I am indebted to both Jonathan Mackman and Matthew Frank Stevens for introducing me to the records of the Court of Common Pleas through their database on British History Online: https://www.british-history.ac.uk/no-series/common-pleas/1399-1500
} 
detinue, these historians have examined family inheritance issues and economic changes in London and its environs. ${ }^{99}$ Walker uses the records of the Court of Common Pleas in her examination of succession and practices of marriage among the elite. ${ }^{100}$ Mackman shows that these records can be used to glean quite a bit of information, especially when they have entered the pleading stages in his book chapter, "Hidden Gems' in the records of the Common Pleas.”101 Here, Mackman analyzes a case of detinue not only for what it reveals about the jewels involved, but also what it illustrates about secular relationships between ecclesiastical figures. Stevens has published a variety of articles and book chapters in which he examines women in debt cases. ${ }^{102}$ For one example, in Stevens's book chapter, “London's Married Women, Debt Litigation and Coverture in the Court of Common Pleas," he explores the number of married women who appeared before the court. He challenges the notion that women appeared in court most often in cases related to land disputes by showing that women appeared on their own and with their husbands frequently for debt litigation. These historians have helped illustrate how much information can be ascertained from the pleaded cases before the Court of Common Pleas. My dissertation builds off this idea that pleaded records reveal a significant amount of information, but shifts the focus to what can be learned about litigant maneuvering and concepts of violence, in particular some of the differences between an appeal of wounding or mayhem and using trespass vi et armis, rather than debt or family relations.

\footnotetext{
${ }^{99}$ Detinue was employed to recover illegally seized moveable personal property, i.e. goods. This was used in place or in addition to trespass vi et armis as accusations of theft would not result in the return of the goods in question. 100 Walker, "The Feudal Family and the Common Law Courts."

101 Mackman, "'Hidden Gems'."

102 Stevens, "Failed Arbitrations before the Court of Common Pleas"; Matthew Frank Stevens, "Londoners and the Court of Common Pleas," in London and Beyond: Essays in Honour of Derek Keene, ed. Matthew Davies, and James A. Galloway (London: Institute of Historical Research, 2012); Matthew Frank Stevens, "London Women, the Courts and the 'Golden Age': A Quantitative Analysis of Female Litigants in the Fourteenth and Fifteenth Centuries," London Journal 37, no. 2 (2013); Stevens, "London's Married Women”; Matthew Frank Stevens, "London Creditors and the Fifteenth-Century Depression,” Economic History Review 69, no. 4 (2016).
} 


\section{Evidence and Methodology}

The plea rolls of the Court of Common Pleas form the evidentiary base of this dissertation. Cases heard before the Court of Common Pleas encompassed four main jurisdictions, each with several subcategories; real actions, which mostly included disputes over titles to land; personal actions, which included cases of debt or breach of contract, for example; mixed actions, usually pertaining to eviction from leased lands or houses; and trespass, which included breaches of royal statute and vi et armis. ${ }^{103}$ In this dissertation, I focus on the cases from one type of action and subcategory: trespass vi et armis. Actions of trespass covered an array of violent torts, such as assault, abduction, theft, and housebreaking. ${ }^{104}$ These cases are not trial transcripts, nor are they verbatim accounts of what happened before the justices of the Court of Common Pleas. In general, the entries on the plea rolls outline the various stages of a case before the court; entries on the rolls begin with the original writ, continue through sending out various procedural writs, expand when litigants appear and plead before the court, and conclude when a case was either settled or tried. Ideally, these instances would all be entered on the same roll, although there are examples where clerks started an entry on one roll and then re-entered later in the term on a separate roll. ${ }^{105}$ Clerks of the court diligently recorded the original writs issued from the Court of Chancery. They summarized the arguments given in open court when it

\footnotetext{
103 Jonathan Mackman, and Matthew Frank Stevens, "Introducing the Common Pleas." Court of Common Pleas: The National Archives, CP40: 1399-1500 British History Online (2010): http://www.britishhistory.ac.uk/report.aspx?compid=119287.

${ }^{104}$ Housebreaking was most equivalent to the modern concept of breaking and entering, meaning one had to break a lock or gate or window to gain entrance to the grounds or house.

${ }^{105}$ For example, William Bitterley accused William Ullesby of assault. The entry began on CP 40/577, rot. 302d with just the original writ, Bitterley's count, and Ullesby's denial of any wrong-doing. Just a few rotuli later, Bitterley and Ullesby appear again: CP 40/577, rot. 349. With the exception of the scribe spelling Bitterley as Buterley in this second rendition, the rest of the case up to the denial by Ullesby was verbatim to the previous entry, including the space for the name of Bitterley's attorney. However, in the later entry Ullesby goes on to explain why he should not be in court over this issue, ending with both parties agreeing to a jury trial and a writ being sent to the sheriff (presumably of London).
} 
came to the pleading stage, all in highly formulaic language. And they also enrolled returned writs from various sheriffs in response to the procedural writs sent out by the clerks of the Court of Common Pleas, as well as the enrolled returns from courts when there were results of trials.

Before discussing the specific methodologies used, let us pause a moment to consider the records themselves. The original rolls of the Court of Common Pleas, or rotuli, are archived at The National Archives in Kew, London. ${ }^{106}$ In full, they cover the years 1273 to 1874 ; until the eighteenth century, they were written in Latin with clerks of the court using extensive abbreviations. ${ }^{107}$ At TNA, these records are open for researchers to examine, but high resolution images of most the original rolls are also available at the Anglo-American Legal Tradition website. ${ }^{108}$ Each roll, or rotulus, is approximately three feet long and around one foot wide. ${ }^{109}$ While a law term was in session, the individual rotulus would have been rolled up and maintained by the clerk assigned to that county. Whenever information needed to be added to a roll, the clerk would find the correct roll using whatever personal indexing system they had devised; entries were written on the front and back. When a law term ended, all rotuli were given to the Clerk of Estreats; his job was to read through the rolls to record any monies owed the king. Once he was finished, the stack of rotuli were given to the Clerk of Essoins who bound them all together along the top edge. Each plea roll could contain anywhere between 300 and 600 individual rotuli. The bound plea roll was then delivered to the Clerk of the Common Pleas Treasury for storage. ${ }^{110}$ In the fifteenth century, the Treasury of the Common Pleas was in the

\footnotetext{
${ }^{106}$ Hereafter, The National Archives will be referred to as TNA.

107 According to The National Archive, these are relatively intact for the entirety of the time period. While there was some damage on the rolls I used, none were missing. Mackman, and Stevens, "Introducing the Common Pleas."

108 “Anglo-American Legal Tradition.” O'Quinn Law Library at The University of Houston (2015):

http://aalt.law.uh.edu. Hereafter referred to as AALT. AALT is a digital archive assembled by Robert C. Palmer, Elspeth K. Palmer, and Susanne Jenks.

109 Please see Image 1 on page 224 for what a roll looked like.

${ }^{110}$ All information on the creation and storage of the records was taken from Hastings, The Court of Common Pleas in the Fifteenth Century, 44-46. Chapter four of her book goes into great detail about the records.
} 
basement of Westminster Hall, affectionately known by the personnel of the court as "Hell."111

During the end of the fourteenth century and through at least the first half of the fifteenth century, the court was at its busiest. Of the roughly 6,000 entries one might find for a single law term (of four law terms per year), the majority of the entries would concern the mesne process. The mesne process included procedural writs issued by the clerks of the court between when the original writ was delivered and the appearance of the defendant before the Court of Common Pleas. ${ }^{112}$ These procedural writs would have been written on separate pieces of parchment so that they could be delivered to the appropriate person, but would also have been copied onto the roll containing the original writ for that case. For example, a defendant might get a writ of supersedeas which would enable them to avoid being outlawed. ${ }^{113}$ The most common was the writ of venire facias, which instructed the sheriff of the appropriate county to impanel a jury. ${ }^{114}$ Once a writ was delivered, say to the sheriff, he would then write the action he took on the back of the writ and send it back to the Court of Common Pleas; this was called a return, and was also transcribed on to the plea rolls. There was a filing system that would have made this easier for the clerks; each roll was numbered at the bottom and the county in which the suit was laid was notated on the left hand side of the roll.

Extrapolating from one law term, each year under consideration in this dissertation (1405-1415) has roughly 24,000 entries on the rolls for the Court of Common Pleas. While I use Hasting's base number in this calculation as she had the opportunity to count more records than I did, I did a detailed count of all the plea entries for Hilary term in 1410. This count yielded almost 10,000 entries on a single session's roll. At the same time, I counted all the trespass vi et

\footnotetext{
${ }^{111}$ Hastings, The Court of Common Pleas in the Fifteenth Century, 35.

112 Hastings, The Court of Common Pleas in the Fifteenth Century, 7-8.

${ }^{113}$ Hastings, The Court of Common Pleas in the Fifteenth Century, 36.

${ }^{114}$ Hastings, The Court of Common Pleas in the Fifteenth Century, 51.
} 
armis entries for the Hilary term, this yielded around 3,000 cases at some stage of the process; however, not a single case had reached the pleading stage in that term in 1410 . The Court of Common Pleas entertained cases from all across England, which might explain some of the volume of entries. Another explanation is that each time a return occurred as a result of a procedural writ being sent out, it was entered onto the rolls. Administratively speaking, there was quite a bit of paperwork in this court. Of course, for the legal historian this provides a plethora of material to consider.

For the purposes of this dissertation, I focused on cases enrolled out of London, as designated on the left side of the plea rolls. ${ }^{115}$ This allowed me to narrow my cases to ones where the wrongs either happened in London, or at least included Londoners. I examined every plea roll between the years 1405 and $1415 .{ }^{116}$ Choosing these years permitted me to examine instances of violence under the consistency of one ruler amid the surrounding tumultuous decades, those leading to the Lancastrian rise to power and its demise. Henry IV (r. 1399-1413) had mostly solidified his power by 1405 and while the last year and a half of the decade saw a transition to his son, Henry V (r. 1413-1422), with instances of rebellion, the transition was a relatively peaceful transfer of power compared to the end of Richard II's reign (r. 1377-1399). The Court of Common Pleas records between 1405 and 1415, with a focus on London, represents a compelling window of time in which to investigate how people conceptualized violence and pursued litigation over violent acts without the influence of warfare. ${ }^{117}$ I further narrowed my focus to cases that had reached the pleading stage of the process. This whittled

\footnotetext{
115 Image 2, of a pleaded case, on page 227 illustrates this.

116 This was done not only at TNA, where the original records are kept, but also with the help of images of the plea rolls uploaded to AALT.

${ }^{117}$ While all of the records were enrolled between 1405 and 1415, some of the alleged instances occurred before 1405.
} 
down the sample size from roughly 30,000 entries to eighty-two unique cases which dealt with trespass vi et armis. ${ }^{118}$ By limiting my cases to those in the pleading stages, I also increased the scope of information contained in the entry. Defendants in forty cases simply pleaded "not guilty" and offered no other explanations; however, in forty-two cases, defendants did have something to say about the accusations against them.

By focusing on London, I am able to see a greater cross-section of society in which to examine these ideas of licit and illicit violence. London and Londoners represent an ideal focal point for two reasons: first, as the largest city in England, it had a varied population, which provides a greater sampling across gender, status, and occupation. Second, Londoners avoided the cost of travel from afar to reach Westminster and the Court of Common Pleas, which again allows for a better cross-section of cases from which to draw data. For example, Philippa Maddern examined cases in the Court of the King's Bench enrolled between the years 1422 and 1442 and found that " 23.5 per cent of plaintiffs are recorded as being of gentry status or above" while yeomen and husbandmen made up "51.8 per cent of the defendants." 119 In comparison, in the cases below, only four percent were listed as gentry or above and fifty-four percent were classed as merchants or artisans. ${ }^{120}$ Part of this differential is, of course, the location from which our data was respectively drawn.

This project uses methodologies adapted from social, legal, and cultural history. While some of my subjects may have had titles, the majority of the people pleading cases in the Court of Common Pleas were probably merchants and artisans. ${ }^{121}$ These records allow me to examine

\footnotetext{
118 There were eighty-two unique entries as in four instances cases continued in later terms, or even just later on the same term's records, with additional information.

${ }^{119}$ Maddern, Violence and Social Order, 38, 39. She argues from this data that gentry used the King's Bench to further land disputes in East Anglia.

${ }^{120}$ In terms of wealth or status, merchants might have been on the same level as rural gentry. I will discuss this more in chapter five.

${ }^{121}$ I will discuss this in more detail in chapter five.
} 
how the non-elite in London not only interpreted licit and illicit violence, but also to illustrate that these men and women were socialized in legal knowledge, in the vein of social history. I draw upon currents in legal history to analyze legal records and how they were applied and challenged in court to show the negotiations between litigants and structures of power. In the same vein, I examine how they used the procedures of the Court of Common Pleas to their advantage. Last, I draw from the field of cultural history and am influenced by the archival turn. ${ }^{122}$ Deconstructing texts, for example considering the ways in which violence was categorized and analyzing the interplay between institutes of justice and social mores, offers me a chance to show societal values and constructs of licit and illicit violence in action. In addition, understanding how information not only makes it into the records, but also how it was later stored and classified further illustrates power structures at work. While influenced by these approaches and theories, the core methodology for this study is a qualitative and quantitative analysis of the eighty-two trespass vi et armis actions before the court between 1405 and 1415 . I shift to a quantitative approach in the fifth chapter, which allows me to place the more limited sample set into a larger context. I use the smaller dataset to ascertain individual instances of maneuvering within the court's procedures, while the larger dataset lends statistical relevance.

While there is much to gain from examining these records, they are not without their limitations. The language in the records is highly formulaic; in essence, it was a specialized language used by law clerks. In addition, the clerks used an extensive amount of abbreviation. ${ }^{123}$ These clerks needed to take what was said in open court and reduce it down to the language that

\footnotetext{
${ }^{122}$ I explore the archival turn more in chapter three.

${ }^{123}$ For example, the twelfth line of TNA, CP 40/579, rot. 059. looks like this without the abbreviations filled in: "Et pdtus Johes fil Thome in ppr psona sua ven et defend vim et iniur quando etc et dicit." And this after: "Et $\mathrm{p}$ [rae]d[ic]tus Joh[ann]es fil[ius] Thome in p[ro]pr[ia] p[er]sona sua ven[it] et defend[um] vim et iniur[iam] quando etc et dicit."
} 
would fit the writ being used. The Court of Common Pleas was not interested in issues of guilt or innocence. Cases were not tried in front of this court. The point of appearing before the justices of the Court of Common Pleas was to decide what point of a case a jury at assize court would render a verdict on. That could be guilt or innocence if the defendant pleaded "not guilty". It could be whether a certain tenement belonged to the plaintiff or someone else at the time of the alleged trespass. It could be whether the defendant had acted in self-defense. The trials took place in other courts and very little evidence remains of them. During a medieval trial there were no transcripts made, and there were no court reporters. However, this was where the full story from each side would have been revealed to the onlookers, judge, and jury. This court would have been where witness testimony was given, where stories were corroborated or refuted. ${ }^{124}$ The outcome of the trial would have then been sent to the Court of Common Pleas for the clerks to enroll. Even though we cannot know what these people felt or even thought as the language in the cases is not their own, we can use them to understand what worried people and what wrongful acts compelled them to seek redress. ${ }^{125}$

\section{Argument and Contribution}

In this dissertation, I argue that trespass vi et armis actions in the Court of Common Pleas demonstrate that Londoners were knowledgeable litigants and that they used the court to meet a variety of needs. While plaintiffs chose the court to pursue their own interests, defendants also used the procedures in the court to their advantage. The narratives crafted by both plaintiffs and defendants in these cases suggest complex motives including establishing ownership, forcing (or enforcing) arbitration agreements, as well as negotiating concepts of licit and illicit violence. I

\footnotetext{
${ }^{124}$ Witnesses did not always support the narrative offered by the person who asked them to attend.

${ }^{125}$ I will discuss the various voices that contribute to these documents in chapter three.
} 
contribute to the scholarship in which gender, violence, and law overlap by using records in this dissertation that are often dismissed or relegated to tangential sources. The Court of Common Pleas can be used for more than understanding economic or land disputes; it can also shed light on the different ways in which people possibly experienced violence. More importantly, pleaded cases illustrate the social norms in operation during the early fifteenth century and how litigants used those norms in their complaints or defenses. The machinations in these pleadings indicate that plaintiffs and defendants were savvy litigants, manipulating the system and its procedures to achieve their personal goals. Focusing on appeals of violence, or misdemeanors and felonies, can limit our understanding of how negotiations about violence occurred. Within criminal proceedings, defendants had no ability to add extenuating circumstances to their pleading. While a jury may have explained on record that a killing or assault had occurred as a result of selfdefense and a convicted defendant might have received a pardon for such an action, civil actions concerning violence allowed for a defendant's own accounting of the events. Trespass vi et armis cases provide a rich source for studying not only concepts of violence and how litigants took advantage of civil procedures, but also the ways in which status, occupation, and gender might have influenced these ideas.

Londoners, among many other subjects, chose to use the Court of Common Pleas for these actions because of the advantages offered by a royally-supported court. In addition, litigants gained access to highly trained professionals through which they could make their argument over the issue in question, whether that was arbitration, property possession, or the licitness or illicitness of the violent act. Examining possible motivations as revealed in these cases show that plaintiffs and defendants used this court to achieve a variety of end goals and that both plaintiff and defendant benefited from the use of these civil procedures. These cases 
also suggest that society did not always use the courts to settle disputes, many negotiated among themselves before bringing the suit to the Court of Common Pleas. Cases with assault as one of the torts are an ideal window into what trespass vi et armis cases can illustrate about constructions of violence. When defendants pleaded something other than "not guilty," they demonstrate that the line between licit and illicit acts were not clearly delineated; violence that created order was considered licit, violence that created disorder was illicit. Furthermore, if one analyzes the cases of trespass vi et armis before the Court of Common Pleas using statistical data, one finds disparities based on gender, occupation, and status in the amount of damages requested. A larger dataset also reveals long-term trends in certain types of defenses;,such as self-defense and prior arbitration which defendants used throughout the fifteenth century and self-help which defendants stopped using by the mid-fifteenth century. ${ }^{126}$ Trespass vi et armis actions illustrate how members of society and the law reacted to each other: one influencing development and the other shaping implementation.

\section{Chapter Organization}

Given the complex nature of the law and legal systems, in the second chapter, I explore the various courts and systems of procedure at work in England in the early fifteenth century. There were two distinct levels of secular courts: local and central, within which operated several systems of law. The use of central and local might be misnomers as royal courts were held throughout England. The true distinction was between courts overseen solely by local officials and courts overseen by royal administrators. ${ }^{127}$ Of the two main systems, civil and criminal

\footnotetext{
126 When a defendant used self-help as a defense, the defendant claimed to be asserting a perceived right through a violent act (i.e. taking goods to recover a debt).

127 Technically speaking all justice stemmed from the crown, although local courts were ones in which royal administrators did not have a direct say in terms of who were appointed as judges.
} 
pleas, I focus on civil procedures as trespass vi et armis dealt with wrongs and not misdemeanors or felonies. ${ }^{128}$ In general, both local and central courts entertained the same types of cases, although there was one exception, only royal courts (whether local or central) could hear felony cases. Regardless of which type of court, hearings were performative in nature. The courtroom was a stage on which local dramas played out before judges, juries, and observers. They were places where one could restore or tarnish a reputation, establish one's status or place in the world, seek public redress for wrongs, and even establish what level of violence was deemed acceptable and what was unacceptable.

Londoners had access to a variety of courts in which to carry out and witness these performances, both local and central. Therefore, part of chapter two also examines why Londoners chose to use a more expensive central court, the Court of Common Pleas, in pursuit of justice. Local London courts were plenty, but the three main courts were the Sheriffs', Mayor's, and the Husting courts. In addition to these, royal courts were often held in London. Because of their proximity, Londoners also had easy access to the most powerful central common law courts in England: the Court of the King's Bench and the Court of Common Pleas. Both of these courts, by the fifteenth century, were housed in Westminster Hall, just over three kilometers from Ludgate. ${ }^{129}$ These courts were much more expensive to access than the local courts as potential litigants had to purchase writs from the Court of Chancery in order to have a case heard before either of these courts. Local courts were more accessible, financially speaking, to any person living in London, regardless of economic status, as one could just make an oral complaint in open court. However, there were advantages to using the Court of Common Pleas to pursue

\footnotetext{
${ }^{128}$ That is not to say that these wrongs could not also be tried as a misdemeanor or felony. This was often up to the aggrieved party.

${ }^{129}$ See Map 1 on page $\mathrm{x}$.
} 
one's cause: it had well trained personnel; it had the power to compel attendance for people outside of London; and it had the backing of the crown in its decisions.

As a savvy litigator would understand, the support of the crown carried quite a bit of weight. In the third chapter, I move from the big picture world of systems, procedures, and wrongs, to focus on a specific set of cases. These cases show that careful consideration of trespass vi et armis can yield more information about litigant motivations and expectations. For example, society continued to view arbitration prior to litigation as an acceptable path towards reconciliation and plaintiffs used the initiation of an action to pressure a defendant into arbitration. Part of the problem with historians using trespass vi et armis cases is that they often, as discussed above, dismiss them as being legal fictions in which plaintiffs falsely accused defendants of violence in order to move the wrong from a local to central court. Many people throughout England were socialized into the legal system, in part, as a result of its participatory nature, but also because they could easily observe a court session in progress.

Having gained that knowledge, litigants used it to their advantage. While some plaintiffs might have initiated a suit to force arbitration, some defendants crafted narratives that claimed arbitration had already occurred; a fact they wanted proved at a jury trial. In addition to arbitration, plaintiffs and defendants alike, could use the courts and their performative nature to break or re-establish reputations. Actions concerning abduction and imprisonment were particularly problematic in this respect; for example, respectable members of society who had been wrongly imprisoned sought to restore that reputation through a civil action against the wrongdoers. However, defendants were not without advantages when it came to the procedures of the Court of Common Pleas. When accused of theft and housebreaking, defendants might enter a special pleading that questioned the ownership of the property involved in the dispute. 
Continuing with the exploration the benefits of civil procedures as well as litigant machinations, I shift the focus more firmly to negotiations over licit and illicit violence. In the fourth chapter, I analyze the narratives crafted by defendants in order to justify their violence, or perhaps to excuse it. There is a fine line between these ideas, justify and excuse. One connotes an idea that their actions were just, even if technically wrong. The other makes no claims on justness, but rather connotes a reason why their wrongful act should be overlooked. In quite a few instances in the pleadings in the Court of Common Pleas records, defendants sought to justify their actions. Many do this by claiming that their actions were ultimately licit uses of violence, thereby seeking their peers' validation of their views. Some defendants did this by claiming they acted in self-defense, while others drew on centuries old traditions of violent vengeance.

These cases illustrate the complexities of the debates surrounding violence and how people might have classified certain types of violence as illicit. If the purpose of the law was to decide who was allowed to legally use violence, these cases show that the delineation was open to interpretation. Even in cases where defendants did not admit to the actions of which they were accused, the plaintiff's count was still illustrative of how a person might have experienced violence. Defendants often argued that their use of violence was licit. That these debates were happening in a central court under royally appointed judges exemplifies how this court was a part of the negotiation process. However, the procedural differences between criminal appeals and civil actions reveal the tensions between societal views of licit violence and legal views of licit violence.

Furthermore, these cases illustrate some of the challenges in using these records, such as the use of formulaic language concerning the weapons used. They also demonstrate the spectrum 
of violence present in trespass vi et armis cases. From theft to assault, these cases run the gamut of wrongful acts. The litigants were also coming from a variety of backgrounds. How a merchant valued his person or property might have been different than an artisan; while eighty-two cases does not have a lot of statistical relevance, they hint at the importance of status and occupation in requesting damages. Whether women were involved, as plaintiffs or defendants, influenced the amount of money requested in damages as well. Regardless of who was involved, though, plaintiffs and defendants understood how to use the courts to their advantage and how to maneuver around the more limiting procedures regarding self-defense used in criminal appeals.

In the fifth chapter, I expand the focus beyond the ten years analyzed in the rest of the dissertation. Here, I added to my own statistics by using data obtained from "Court of Common Pleas: The National Archives, CP40: 1399-1500," an online resource, available on British History Online, by Jonathan Mackman and Matthew Frank Stevens. ${ }^{130}$ While the information gained from my own set of cases is highly suggestive of certain trends, adding in cases from over thirty years spread across the century reinforces the results of the more limited dataset. Women who appeared before the Court of Common Pleas are mostly identified by relational or elite status: widow, wife, nobility in some instances, and were often listed as servants when victims of these violent torts. Even if the information contained in the counts and pleadings indicated a married woman was the true complainant, she still had to appear with her husband per the coverture laws in place at the time. This obscures some of the statistics one can get from these cases. Despite this, both datasets show that when a woman was involved in the case as either a defendant or plaintiff, the damages requested were, on average, twenty-five percent less than

\footnotetext{
130 Jonathan Mackman, and Matthew Frank Stevens, "Court of Common Pleas: The National Archives, Cp40 13991500.” British History Online (2010): accessed 3/16/2019, https://www.british-history.ac.uk/no-series/commonpleas/1399-1500.
} 
when only men were named. While damages requested clearly had personal reasons behind the amounts, it also seemed to matter what type of violent tort; broken down by tort, the statistics do change. The analysis of these cases suggests clearly that women and any possible damage to them or by them was valued less than that done to or by men.

Gender is not the only category I analyze in this last chapter. I also examine how status and occupation affected the damages requested as well as how negotiations over licit and illicit violence changed over time. For both the dissertation and dataset created by Mackman and Stevens, the results were the same. On average, when status or occupation was listed for either the defendant or plaintiff, the damages requested were twenty-two percent more than when none were given. Similar to the trend with gender, it is evident that status and occupation influenced how much plaintiffs asked for, but it is unclear what the rationale behind this was. Plaintiffs were not required to explain to the courts why they wanted a certain amount of money. While damage requests remained relatively stable throughout the fifteenth century, ideas of self-help, including self-defense did seem to change. There were more cases of defendants pleading self-defense in the first half of the century than in the latter. Furthermore, fewer defendants crafted narratives that centered around violent vengeance and self-help as the century wore on. As with the centuries before, more and more individual violence came to be classified as illicit and societal norms pertaining to these notions of violence changed as well. 


\section{Chapter 2 - The Legal Worlds of Medieval England}

\section{Introduction}

On the Monday after the Feast of the Nativity of St. John the Baptist in 1410, Thomas

Fancoby allegedly broke into the close of Richard Fox; the close in question was located in the parish of St. Sepulchre, in the ward of Farringdon Without. ${ }^{1}$ During this close-breaking, Fancoby also cut down (using an axe) and carried away ten pounds worth of trees growing on Fox's property. ${ }^{2}$ Fancoby appeared, in person, in front of the Court of Common Pleas in the 1411 Michaelmas law term to respond to the allegation that he had absconded with "five pear trees, five apple trees, four white firs, and six cherry trees." 3 Fox claimed damages of forty pounds for this arboreal theft; Fancoby denied all charges. After the order was sent to the sheriff of London to impanel a jury, Fancoby appointed Richard Edmond to appear on his behalf; which is the end of the case in the Court of Common Pleas records. ${ }^{4}$ A case such as this can leave the researcher with a variety of logistical questions: such as how long did it take Fancoby to cut down twenty trees and why did no one see this happening $?^{5}$ However, it can also lead to more practical questions: how does one navigate the complex systems of English law?; how was Fancoby informed of the impending court date so that he knew when and where to appear?; why did Fox sue in this court rather than any of the others available?

\footnotetext{
${ }^{1}$ The National Archives, CP 40/603, rot. 483d; hereafter, TNA.

2 The close-breaking was not a part of the wrong, as housebreaking would have been.

${ }^{3}$ In Latin this was, "videlicet quinque piros quinque pomos, quatuorum avelanos et sex seresos." The Monday after St. John's feast day was June 30. Michaelmas law term was between October 9 and November 28 for 1411, which means Fancoby was answering these accusations over a year from when the initial event allegedly occurred. See the discussion on page 50 for more on law terms, as well as in Appendix C on page 225.

${ }^{4}$ Richard Edmond was an attorney. Between 1405 and 1415, he appears in three other cases, all as the attorney for the plaintiff, rather than defendant as in this case. Before 1405, he appeared in four other cases, all as the attorney for the plaintiff.

${ }^{5}$ Others that come to mind include how was he able to transport them? Did he have accomplices to help? How big were these trees?
} 
In this chapter, I show not only how the courts operated during the fifteenth century but also how pervasive the legal structures were for medieval Londoners. Even those people who might not have been able to sue in a court of law saw the systems of justice in action, quite possibly on a daily basis, and also witnessed the litigiousness of their fellow Londoners; more than a few experienced it first-hand. Fox, from the case mentioned above, would have been familiar with the law courts available to him; moving through the streets of London, he would have seen these courts in operation and the same would be true for Fancoby. This does not mean they had to navigate these systems alone. For the question of who to turn to for help, at least, the answer was clear to Fancoby after his first appearance before the Court of Common Pleas: hire an attorney.

For many people in the modern world without specialized knowledge of the legal system, navigating the rules, terminology, and courts can seem like stepping foot into foreign territory. This confusion was probably intensified for the average medieval English person. The sheer number of courts from which to choose, along with the use of non-English languages and a staggering array of statutes, customs, and procedures might have been overwhelming. In some ways the volume of laws and procedures is evidenced in not only the numerous texts devoted to legal history but also the number of pages in those texts. ${ }^{6}$ Some of the seminal works on the history of English laws from the late nineteenth and early twentieth century were either published in multiple volumes or came to over 700 pages. $^{7}$ Others represent the culmination of several decades of work in a single volume. ${ }^{8}$ The size of these generalized histories of English

\footnotetext{
${ }^{6}$ To give an entire review of this literature is beyond the scope of this dissertation.

${ }^{7}$ Sir Frederick Pollock, and Frederic William Maitland, The History of English Law Before the Time of Edward I (Cambridge: Cambridge University Press, 1895); William Holdsworth, A History of English Law, Vol 4 (London: Methuen \& Co, Ltd, 1923); Theodore Frank Thomas Plucknett, A Concise History of the Common Law (Rochester, NY: The Lawyers Co-Operative Publishing Company, 1929).

${ }^{8}$ S.F.C. Milsom, Historical Foundations of the Common Law (London: Butterworths, 1981); S.F.C. Milsom, Studies in the History of the Common Law (London: Hambledon Press, 1985).
} 
law do not tend to shrink over time: The Oxford History of the Laws of England is set to have twelve volumes, with the first having come out in 2003. While J.H. Baker's volume was the first published, it is technically sixth in the series and takes over 1,000 pages to provide a detailed examination of the laws, systems, and personnel of the court between 1483 and $1558 .{ }^{9}$ Baker's other overview of English laws, which is in its fifth edition and is one of the best all-around reference works for the entirety of English legal history, is nearly as lengthy. ${ }^{10}$ English law and its legal systems were not only complex, but they also changed over the course of the Middle Ages.

Some legal scholars choose to examine particular aspects of law, such as crime or trespass, or time periods, like the Anglo-Saxon period or the fourteenth century in order to provide more in-depth analyses within a complex system. John Bellamy's work provides students and scholars alike with an excellent overview of crime and criminal procedures in late medieval England. ${ }^{11}$ George Woodbine examined, at great length, the antecedents of trespass actions in his two part article, "Origins of the Action of Trespass." 12 Unlike Bellamy or Woodbine, Tom Lambert chose to examine the chronological snapshot of the English legal system in his work, Law and Order in Anglo-Saxon England. ${ }^{13}$ Many of these histories, such as Lambert's, also explain the evolution of the law and legal systems in England; they examine the almost symbiotic relationship between society and systems of justice and the ways they respond to the demands of each other so that it can be difficult to determine cause and effect with any

\footnotetext{
9 J.H. Baker, The Oxford History of the Laws of England, Vol. 6 (Oxford: Oxford University Press, 2003).

${ }^{10}$ J.H. Baker, An Introduction to English Legal History (Oxford: Oxford University Press, 2007).

11 J.G. Bellamy, Criminal Law and Society in Late Medieval and Tudor England (New York: St. Martin's Press, 1984); J.G. Bellamy, The Criminal Trial in Later Medieval England: Felony Before the Courts From Edward I to the Sixteenth Century (Toronto: University of Toronto Press, 1998).

12 George E Woodbine, “Origins of the Action of Trespass," Yale Law Journal 33, no. 8 (1924); George E Woodbine, "Origins of the Action of Trespass," Yale Law Journal 34, no. 4 (1925).

${ }^{13}$ T. B. Lambert, Law and Order in Anglo-Saxon England (Oxford: Oxford University Press, 2017).
} 
measure of certainty. In a similar vein to Woodbine, I am only concerned with trespass vi et armis, although not in how it came about, but rather how litigants used it to pursue their agendas in court. In addition, my dissertation is limited in scope and so the data I gathered only suggests at the symbiotic relationship between society and law.

An excellent example of scholarship that shows the nature of the connection between people and their legal system is Anthony Musson and W.M. Ormrod's book, The Evolution of English Justice. More limited than general histories of law, this book focuses on the hundredyear period before 1390, with its authors analyzing the influential changes that took place in that century. Robert Palmer analyzes a similar, albeit slightly smaller, time period in his book, English Law in the Age of the Black Death, 1348-1381. Palmer concludes that the people in power altered the law in order to restore stability after the Black Death ravaged England. ${ }^{14}$ However, it is a view disputed by Musson and Ormrod, and in a small way, by this dissertation as well. Musson and Ormrod argue that changes in the law happen gradually over time, rather than in short bursts as a result of crises (perceived or real). ${ }^{15}$ Edward Powell combines these two approaches (thematic and chronological) by investigating how criminal procedure evolved during the reign of Henry V (r. 1413-1422) in his book, Kingship, Law, and Society. ${ }^{16} \mathrm{He}$ reaches back into the thirteenth and fourteenth centuries to show how distribution of justice increasingly supported central authority in order to bolster his argument that the point of the superior eyre sent out by Henry V was to settle disputes among landholders, quite possibly in

\footnotetext{
${ }^{14}$ Robert C. Palmer, English Law in the Age of the Black Death, 1348-1381: A Transformation of Governance and Law (Chapel Hill: University of North Carolina Press, 1993).

15 Anthony Musson, and W. M. Ormrod, The Evolution of English Justice: Law, Politics, and Society in the Fourteenth Century (New York: St. Martin's Press, 1999).

${ }^{16}$ Philippa Maddern's book, discussed in chapter one in more detail, is another excellent example of combining narrow thematic scope (violence), with equally limited time (1422-1442) and location (East Anglia). Violence and Social Order: East Anglia 1422-1442 (Oxford: Oxford University Press, 1992).
} 
order to turn their minds towards the war he wanted to continue with France. ${ }^{17}$ Musson and Ormrod, Palmer, and Powell all assert, as do I, that the legal system responded to the demands of the people who sought access to it and especially those who used it. ${ }^{18}$

However, a legal system cannot respond to the needs of the people without said people interacting with it to pursue their complaints or appeals. For most people, this occurred in the courts, whether local or central, of medieval England. Similar to histories of law, some scholars studied medieval English courts in their entirety. Perhaps the best example of this is Alan Harding's book, The Law Courts of Medieval England. ${ }^{19}$ In this slim volume, Harding provides an overview of the evolution of the courts in use over the span of the Middle Ages, beginning with Anglo-Saxon era and ending with the sixteenth century. Given the sheer number of courts coming in and out of operation in England over this 600-year span of time, it is little wonder that many scholars opt to focus on specific courts or the courts in a particular locale instead of attempting to discuss the history of legal systems in action.

Microhistories, whether by court or location, such as those by Margaret Hastings, Marjorie Blatcher, or Penny Tucker, provide more nuanced views of society, courts, and the law in both rural and urban areas. ${ }^{20}$ Hastings wrote the seminal work on the Court of Common Pleas

\footnotetext{
${ }^{17}$ Edward Powell, Kingship, Law, and Society: Criminal Justice in the Reign of Henry V (Oxford: Clarendon Press, 1989).

${ }^{18}$ Musson, and Ormrod, The Evolution of English Justice: Law, Politics, and Society in the Fourteenth Century, 116-17; Palmer, English law in the age of the Black Death, 5; Powell, Kingship, Law, and Society: Criminal Justice in the Reign of Henry $V$.

${ }^{19}$ Alan Harding, The Law Courts of Medieval England, (London: Allen \& Unwin, 1973). While this is a tertiary source, he does construct some of his arguments using primary sources, as well as include many primary sources for the students who might use the book.

${ }^{20}$ Marjorie Blatcher, The Court of King's Bench, 1450-1550: A Study in Self-Help (London: Athlone Press, 1978); Margaret Hastings, The Court of Common Pleas in Fifteenth Century England: A Study of Legal Administration and Procedure (Ithaca: Cornell University Press, 1947); Penny Tucker, Law Courts and Lawyers in the City of London 1300-1550 (Cambridge Studies in English Legal History) (Cambridge: Cambridge University Press, 2007).

Examples of histories of specific types of courts like manor courts or gaol deliveries include Chris Briggs, "Manor Court Procedures, Debt Litigation Levels, and Rural Credit Provision in England, c. 1290-c. 1380," Law and History Review 24, no. 3 (2006); Edward Powell, "Jury Trial at Gaol Delivery in the Late Middle Ages The Midland Circuit, 1400-1429," in Twelve Good Men and True: The Criminal Trial Jury in England, 1200-1800, ed. J. S. Cockburn,
} 
in the fifteenth century and Blatcher wrote about the Court of the King's Bench in the late Middle Ages ${ }^{21}$ Their investigations into the two premier common law courts of England show the interaction and competition among the courts' personnel. Tucker's examination of London's courts and her investigation into the relationship between the local courts, royal courts, and central courts demonstrates the overlapping nature of jurisdictions and personnel. More than this, though, they show how these legal structures were built into the local communities. These histories demonstrate the constancy of law and how omni-present the legal system was in people's lives. Any of these histories of law, common law, courts, lawyers, and crime illustrate the complexities of law, legal systems, and language used within the courts.

\section{Overview of England's Legal System}

England's legal system developed over many centuries and combined elements of Roman, Germanic, and various local laws, customs, and procedures. While written laws developed after $597 \mathrm{CE}$, it was not until the mid-thirteenth century that clerks had two treatises detailing the system of writs and actions which were permitted in the king's courts. ${ }^{22}$ These treatises by Glanvill and Bracton, and based on Roman civil law, influenced the procedures used in the English courts. ${ }^{23}$ After 1066, early English laws were combined with Norman laws and procedure to create a system that became increasingly complicated to navigate. It was also during the thirteenth century that the use of juries rose in prominence throughout England's

and Thomas A. Green (Princeton: Princeton University Press, 1988).

${ }^{21}$ I discuss both Hastings' and Blatcher's works in more detail in chapter one.

${ }^{22}$ King Æthelberht of Kent seems to have issued the first law code in the post Roman era. See Lambert, Law and Order in Anglo-Saxon England, 28.

${ }^{23}$ Paul Dryburgh, "The Law and Legal Records: An Overview," Postgraduate Archival Training (PAST): Medieval Legal Records Workshop, The National Archives (2018); See Michael T Clanchy, From Memory to Written Record: England 1066-1307 (Chichester: Wiley-Blackwell, 2013). for a more detailed look at the expansion of both the courts and written documentation. 
courts. ${ }^{24}$ Records, writs, and other pertinent court procedures were all recorded in Latin, while oral arguments between lawyers and serjeants at law in the central courts were in Law French, although actual proceedings during a trial were probably in English, especially after $1356 .{ }^{25}$ In addition, anyone could assert ancient custom as a way to maintain rights that might not be fully legal, which is why common law was not necessarily the same in every court throughout England. ${ }^{26}$

There were two branches of courts in the late medieval English system: local and central courts. ${ }^{27}$ Within these branches operated several systems of law, which meant that various courts and systems overlapped between the branches. ${ }^{28}$ The main systems of law were criminal and civil pleas. There was also a division of secular and ecclesiastical courts, and while ecclesiastical courts were important during the Middle Ages, they did not entertain trespass vi et armis actions, which is the core set of sources for this dissertation. Central courts could be further divided between common law and non-common law courts; local courts were mostly common law courts, although some, like manorial or leet courts, were customary courts. ${ }^{29}$ Plaintiffs who wanted to use the action of trespass vi et armis only had three options in the early fifteenth century: the local courts, the Court of the King's Bench, or the Court of Common Pleas. Perhaps

\footnotetext{
${ }^{24}$ James Masschaele, Jury, State, and Society in Medieval England (New York: Palgrave Macmillan, 2008), 46.

${ }^{25}$ Tucker, Law Courts and Lawyers in London, 336; Anthony Musson, Medieval Law in Context: The Growth of Legal Consciousness from Magna Carta to the Peasants' Revolt (Manchester: Manchester University Press, 2001), 168-69.

${ }^{26}$ Common law is the entirety of the laws and customs for England, but it allows for local variations in custom. Tucker, Law Courts and Lawyers in London, 32-33.

${ }^{27}$ Here, I am adopting Penny Tucker's classification of the English legal system. As she argues, all courts were either controlled by the king or held at the king's pleasure. She calls it "delegated jurisdiction." Tucker, Law Courts and Lawyers in London, 91. Central courts, the ones most historians classify as royal are those operating out of Westminster Hall. All other courts were local courts, whether they were administered by the king's justices or local administrators. See Appendix D page 226 for a visual representation of this system.

${ }^{28}$ Paul Dryburgh of The National Archives noted five systems: customary, common, prerogative, equity, and civil/church/naval. Dryburgh, "The Law and Legal Records."

${ }^{29}$ While central courts could be common law courts (as was the case for three of them), it was a narrower version of common law as it did not allow for local custom. See Tucker, Law Courts and Lawyers in London, 32.
} 
the biggest difference between local and central courts was how litigants initiated actions. In local courts, litigants initiated suits by written bill or oral complaint, whereas in central courts they had to be initiated by royal writ. ${ }^{30}$ Regardless of which branch, system, or type of court, they were all supposed to abide by the same term schedule: Michaelmas, Hilary, Trinity, and Easter. ${ }^{31}$ Court sessions were designed to avoid any major agricultural events or religious festivals. Some locally held courts might also skip the summer sessions as judges were often away on the king's business or they simply wished to remain in the countryside during months when disease more readily spread.

Local courts were courts that operated in the counties and towns of England. They included private courts, such as manorial and honorial (or seigneurial) courts. Ecclesiastical courts operated under their own legal code, canon law, and while some wrongs and procedures might overlap with that of the secular courts it was a distinct legal system. However, they were an alternate avenue of justice for many issues at the community and personal level. ${ }^{32}$ Borough courts operated under the auspices of their respective city, or borough, government. The privileges granted to these courts were outlined in their charters, granted by the king. For instance, London's charter allowed for a number of privileges in regards to their courts, highlighting its importance, from the perspective of the central government and of Londoners,

\footnotetext{
${ }^{30}$ Tucker, Law Courts and Lawyers in London, 5.

${ }^{31}$ Legal years opened with Michaelmas, which lasted from October 9 or 10 until November 28 or 29; it was a relatively fixed term and the longest law term. This was followed by Hilary, another relative fixed term, which ran from January 23 until February 12 or 13. Easter was the next term and also had the most possible start days. It began fifteen days after Easter Sunday, which meant it could start any time between April 9 and May 12, depending on when Easter was observed. It would run until May 5 or June 7, depending on the start date. Trinity was the last law law term. It began eight days after Trinity Sunday, which meant its start date was between May 22 and June 30. It would run until June 10 or July 21, again depending on the start date of the term. C.R. Cheney, and Michael Jones, $A$ Handbook of Dates: For Students of British History (Cambridge: Cambridge University Press, 2004), 98-143. A full list of the law terms used in this dissertation is in Appendix $C$ on page 225.

${ }^{32}$ However, they were not governed by the crown or English government, but rather by English bishops. Cases in these courts could be appealed to the papacy in Rome.
} 
over other cities; indeed, throughout the fifteenth century London was a county unto itself. ${ }^{33}$ Hundred and county courts were both based on the shires of England, or counties. The county court was presided over by the sheriff of that county and usually heard more serious offenses that came up from the hundred court. None of these courts, borough, hundred, or county, could hear civil cases involving debt or detinue that claimed damages over forty shillings without a writ from a central court. ${ }^{34}$

Central courts were divided between non-common law courts and common law courts. Non-common law courts operating during the fifteenth century included Chancery and Admiralty. ${ }^{35}$ Chancery held a pre-eminent position, while the rest held varying and often overlapping jurisdictions. All writs in the common law courts were initiated through the Court of Chancery and of all the courts in England, a process which began with Edward I (r. 12721307). ${ }^{36}$ Chancery was the only court with no review oversight; cases decided in the Court of Chancery were never reviewed by another court or special committee. These privileges were what set Chancery apart from and slightly above the other courts. There were three common law courts: the Exchequer, the Court of the King's Bench, and the Court of Common Pleas. The Exchequer heard cases dealing with money owed to the royal treasury. The Court of the King's Bench heard cases using both criminal and civil procedures and shared trespass vi et armis writs with the Court of Common Pleas. Of course, above all systems was the king and the king's

\footnotetext{
${ }^{33}$ As a county, London chose its own sheriffs. Another legal privilege enjoyed by Londoners was that they could, in debt cases, take repayment from someone who owed a debt to the defendant being sued, which was something only the king could normally do. Tucker, Law Courts and Lawyers in London, 80.

${ }^{34}$ John Beckerman, "The Forty-Shilling Jurisdictional Limit in Medieval English Personal Actions," in Legal History Studies, ed. Dafydd Jenkins (London: University of Wales Press, 1975), 111.

${ }^{35}$ Chancery acted as an oversight body from at least the mid thirteenth century but developed as a court of first resort by 1450 . The Admiralty Court began hearing cases as early as 1357 but had limited jurisdiction. Two noncommon law courts developed in the later fifteenth century. Star Chamber was officially created around 1487. And the Court of Requests developed in 1483. Harding, The Law Courts of Medieval England, 101, 106-107.

${ }^{36}$ Harding, The Law Courts of Medieval England, 99.
} 
council, but even their power of oversight was limited to cases outside of Chancery. ${ }^{37}$

Given the complexities of the English legal system and of English law, I have narrowed the majority of the focus of this chapter to only the courts open to Englishmen and women who wished to initiate a trespass vi et armis action: a local court, the Court of the King's Bench, or the Court of Common Pleas. In terms of local courts, those would be the ones which Londoners, like Richard Fox, from the case which opened this chapter, would have had access to in pursuit of his case against Thomas Fancoby. Most medieval people first encountered the law at the local level whether that was through a private court (such as manorial courts) or public court (such as hundred courts). Therefore, the first section examines the city courts of London, with a particular emphasis on the courts, Hustings, Mayor's, and Sheriffs', that might have heard violent trespass suit. Actions of trespass covered an array of violent torts, such as assault, abduction, theft, and breaking and entering. These were not criminal proceedings, but rather cases which used civil procedure to recover monetary compensation for the damages incurred as a result of a wrongful act, or tort. While many medieval people might have experienced royal justice at the local level, fewer did so at the central courts in Westminster Hall. A brief overview of the Court of the King's Bench is the heart of the next section, which was one of two central courts that could entertain violent trespass actions. However, the premier court of civil litigation in England was the Court of Common Pleas, which had an elaborate setting and intricate rules. This court and the procedures for bringing a civil action to it form the core of the last two sections. Throughout this chapter, I show that fifteenth-century Londoners had a variety of options open to them for pursuing a person (or people) for a violent act and the more wealth one had, the greater those options became. They could appeal the alleged perpetrator for a felony in either the city or at

${ }^{37}$ Dryburgh, "The Law and Legal Records." 
Westminster Hall, or pursue civil proceedings, again either in a city court or a central court.

Local, city courts could be fraught with delays, clogged with cases, or staffed with less

competent judges. ${ }^{38}$ A local court might also include the business partners of, or people who

sympathized with, either the plaintiff or defendant, thus creating a court setting biased against

one of the litigants. Procedures also differed between criminal and civil suits.

\section{London Courts}

London was a bustling, vibrant city, a key player in national politics and the economy. It also, from the 1300 s on, was near the central courts. ${ }^{39}$ Royal justice was still attainable throughout England, but for people of the capital, some 40,000 in 1400, local and central justice could overlap almost effortlessly. ${ }^{40}$ Londoners had access to a variety of local, or city, courts, including the Hustings, Mayor's, and Sheriffs' courts. The city courts of London began as a mishmash of arrangements in the thirteenth century, but by the fifteenth century they were formalized and well documented. While there were a variety of branches, there was no clear distinction between them as expectations and jurisdictions overlapped. ${ }^{41}$ According to Tucker, lines were also blurred between formal courts, informal courts, administrative courts, and legal courts as medieval Londoners had a "tendency to regard as a court any situation in which a

\footnotetext{
${ }^{38}$ Legal training was not a requirement to become a judge in a city court; the judgeships were filled by the elected officials of the city: mayor, sheriff, and aldermen. See Tucker, Law Courts and Lawyers in London, 220. In central courts, only those men trained in the Inns of Court could become a judge. Judges worked their way up to that rank after many years in the courts. For more information on the Inns of Court and legal training See J.H. Baker, The Third University of England: The Inns of Court and the Common-Law Tradition (London: Selden Society, 1990); James A. Brundage, The Medieval Origins of the Legal Profession: Canonists, Civilians, and Courts (Chicago: University of Chicago Press, 2008).

39 The Court of Common Pleas, the Court of King's Bench and the Exchequer all sat in Westminster Hall, which, while only a short walk (roughly two miles) from the walls of London, was in the city of Westminster. John Stow, The Survey of London: Conteyning The Originall, Antiquity, Increase, Moderne Estate, and Description of that City, Written in the Yeare 1598, by John Stow Citizen of London (London: John Windet, 1603), 471-72.

${ }^{40}$ Caroline M. Barron, London in the Later Middle Ages: Government and People, 1200-1500 (Oxford: Oxford University Press, 2004), 4.

${ }^{41}$ Barron, London in the Later Middle Ages, 121.
} 
judgment of some sort was being rendered." ${ }^{42}$ There were, according to John Stow, at least nine courts held in the Guildhall although not all of them were around in the early fifteenth century. ${ }^{43}$ Some of these were administrative courts, others were law courts, and still others only dealt with city companies or city government ${ }^{44}$.

At the lowest level of city government was the ward. By 1395, there were twenty-five wards in London, each presided over by an elected alderman. ${ }^{45}$ Within the ward, male citizens would meet at a gathering called the ward-mote. ${ }^{46}$ These would convene at whatever location was handy: homes, guildhalls, company headquarters, or church yards. The ward-mote conducted a variety of business. Elections for juries, aldermen, and other ward officers occurred here, as did the sharing of important civic announcements, and arranging watches and defense (when necessary) ${ }^{47}$. However, the ward-mote was probably not a court of law; in fact by the 1300 s there was no indication that they decided on cases. ${ }^{48}$ Perhaps the most important function of the ward-mote was the selection of the jury to present malefactors from the ward. These presentments would then be carried forward to the appropriate city law court: Hustings, Mayor's, or Sheriffs' ${ }^{49}$

\footnotetext{
${ }^{42}$ Tucker, Law Courts and Lawyers in London, 88-89.

43 John Stow wrote his chronicle of London in 1598.

${ }^{44}$ As cited by Tucker, Law Courts and Lawyers in London, 87. The nine courts were 1. Common Council (government and legislation) 2. Hallmote (city companies) 3. Court of Orphans (administrative) 4. Chamberlains Court (administrative) 5. Hustings (law) 6. Mayor's Court (law) 7. Court of Requests (law, conscience: formed in sixteenth century), 8. Sheriffs' Court (law), and 9. The Wardmote (also known as the Mayor's General Court; law). This last court heard returns from the individual wardmotes and was a special session of the Mayor's Court.

${ }^{45}$ There is some inconsistency as to the number of wards in London. Caroline Barron identifies twenty-five wards by 1395; however, Penny Tucker identifies only twenty-four wards within the walls of London. Both are technically correct as there were only twenty-four wards in the walls, with one ward outside of the city walls for twenty-five wards total. Barron, London in the Later Middle Ages, 121; Tucker, Law Courts and Lawyers in London, 26. See Map 2 on page 134 for the wards circa 1405-1415.

${ }^{46}$ Not to be confused with The Wardmote which was at the city level and was not a court used very often.

${ }^{47}$ A comprehensive listing of aldermen and mayors between 1300 and 1500 can be found in Sylvia L. Thrupp, The Merchant Class of Medieval London, 1300-1500 (Lansing: University of Michigan Press, 1989), 321-377.

48 Tucker, Law Courts and Lawyers in London, 87-88.

${ }^{49}$ Barron, London in the Later Middle Ages, 121-23.
} 
While these three courts (Husting, Mayor's, and Sheriffs') were not the only courts operating within London, they were the main city courts. ${ }^{50}$ Other courts operated within the city as well, including church courts and certain private courts. In addition, there were courts held in the city at the king's request, such as gaol delivery and oyer and terminer.${ }^{51}$ Finally, there were special sessions, like the assizes of nuisance or the coroner's inquests, which were often presided over by city officials, but were not considered city courts. ${ }^{52}$ A caveat in Henry III's charter in 1268 helped subsume city custom to national custom, although there were a few instances where their jurisdiction was not superseded by the central courts. ${ }^{53}$ Even cases that went before a central court because of an error were more restricted in that justices of the central court did not have access to the written records of the case, but rather were told what happened by the city's recorder..$^{54}$

Throughout the medieval period, the functions of these courts evolved, changed, and sometimes led to new courts being created. However, Tucker asserts that one point was clear by the fifteenth century: "London's law courts were the most important medieval English lay law courts outside Westminster in terms of the quantity of civil litigation brought in them; in the fifteenth century, the London Sheriff's Courts may well have been second only to the central Court of the Common Bench in this respect." ${ }^{, 5}$ While both the London local and central courts

\footnotetext{
${ }^{50}$ Tucker, Law Courts and Lawyers in London, 90. Tucker distinguishes between city courts and courts in the city by defining city courts as any "court which 'belonged' to the city, was peculiar to it, and over which it had control." Law Courts and Lawyers in London, 84.

${ }^{51} \mathrm{Gaol}$ is akin to modern county jails wherein defendants are housed while awaiting trial. See Guy Geltner, The Medieval Prison: A Social History (Princeton: Princeton University Press, 2014); Christine Winter, "Prisons and Punishments in Late Medieval London," diss., Royal Holloway, University of London, 2012). for more detailed overviews of medieval prisons.

52 Tucker, Law Courts and Lawyers in London, 84-85.

${ }^{53}$ Tucker, Law Courts and Lawyers in London, 36-37. Caveat is used here in the sense of a specific stipulation that needed to be met in order for the city to use city custom over national custom: "provided always, that such customs are not contrary to justice and rightful law", as quoted from the charter.

54 Tucker, Law Courts and Lawyers in London, 40.

${ }^{55}$ Tucker, Law Courts and Lawyers in London, 1. What Tucker refers to as the Common Bench is the court that I am calling the Common Pleas, either was an acceptable name, although neither was used during the fifteenth
} 
saw an increase in civil litigation, the records for the London city courts are hard to come by for the fifteenth century. This lack of records was not entirely a product of shoddy record keeping, although that certainly contributed to a staggering lack of extant records from the Sheriffs' Courts. Each sheriff was responsible for his own records and most of those were lost. ${ }^{56}$ Add to this the number of fires that London experienced, not to mention a civil war, two world wars, and the moving and combining of archives, and it might be more surprising that any records survived at all. The Hustings' records are more complete, providing great insight into land, property, and inheritance disputes between Londoners. Quite a few records survive for the Mayor's Court as well, although these plea and memoranda rolls are not complete renditions of cases (in the same way the records from the Court of Common Pleas are not full transcripts of the cases). The plea and memoranda rolls are summaries of cases, judgments, and petitions entered into the Mayor's Court rather than full trial transcripts, which would have included witness testimonies and outcomes. $^{57}$

London enjoyed certain privileges; however, there were very few things that were unique to London in terms of actions before the law. ${ }^{58}$ Tucker argues that the largest distinction between city and national law dealt with the transmission of city property: because of borough custom, "owners of city property could dispose of it freely by will." 59 This led to a number of courts and

century. In the fifteenth century, it was simply called the Bench (de banco) and was distinguished from the King's Bench by omitting the phrase coram Rege in its plea rolls and writs. Hastings, The Court of Common Pleas in the Fifteenth Century, 20. I chose to call it by the more modern name, Court of Common Pleas, to more easily distinguish it from the Court of the King's Bench.

${ }^{56}$ Sheriffs were supposed to hand over their records, but the majority did not. Tucker, Law Courts and Lawyers in London, 12.

${ }^{57}$ Most of the court rolls for the Mayor's Court are lost for the first half of the fifteenth century, which means we only have the plea and memoranda rolls from which to draw; the plea and memoranda rolls contain a fraction of the cases heard in the Mayor's court. The rest of the rolls seem to be devoted to mayoral business. Tucker, Law Courts and Lawyers in London, 9-10, 150. While there are still extant original bills for the Mayor's Court, there are only a smattering of bills from between 1405 and 1415 as found across three sets of records at the London Metropolitan Archives (hereafter, LMA): CLA/024/02/001-003.

${ }^{58}$ Tucker, Law Courts and Lawyers in London, 33.

59 Tucker, Law Courts and Lawyers in London, 49. 
rules within London relating to tenancy, transmission of property, and disseisins. ${ }^{60}$ London also employed slightly different procedures in its courts, although that did not necessarily affect how quickly a case moved through the system. ${ }^{61}$ City courts could order the arrest of defendants for any type of suit long before this was available at the central courts. They could also judge against a defendant who defaulted as well as take goods or arrest anyone who had dealings with a defaulted defendant. ${ }^{62}$ Both city and central courts could arrest for trespass actions, which are the focus of this dissertation. Most importantly, London courts were not restricted by the fortyshilling limit on debt cases that applied to other local courts.

The Husting Court, at one point, entertained both civil actions and misdemeanors, but nothing felonious. ${ }^{63}$ It was, according to Caroline Barron, the "premier judicial court and court of record in the city." ${ }^{64}$ The Husting Court was the equivalent of a rural county court and had both administrative and legal responsibilities. Before 1300, the scope of the Husting was much greater than it was in the 1400s. The two distinct sides of the Husting Court were probably established in 1244: Pleas of Land and Common Pleas. ${ }^{65}$ These hearings would alternate weeks, land and common pleas cases on one week and misdemeanors the next. However, the court did not often trade off as it was supposed to. Indeed, as Tucker explains, it did not meet regularly at all and "a consequence of the irregularity and hence unpredictability of Husting sessions was that it was

\footnotetext{
${ }^{60}$ See Tucker, Law Courts and Lawyers in London, 48-55. for more detailed information on the importance of land within the city. Disseisin was employed to recover illegally seized non-moveable personal property, i.e. land.

${ }^{61}$ Tucker, Law Courts and Lawyers in London, 75.

${ }^{62}$ Tucker, Law Courts and Lawyers in London, 76-79. Defaulting means the defendant neither appeared in court themselves nor sent someone to appear on their behalf, such as an attorney.

${ }^{63}$ Felonies, by law, had to be heard in a court presided over by a royally appointed justice.

${ }^{64}$ Barron, London in the Later Middle Ages, 128.

${ }^{65}$ Tucker, Law Courts and Lawyers in London, 94. R.R. Sharpe declines to assert an actual starting date, but he does talk about a new ordinance, 28 Henry III, which was implemented around 1243 or 1244, which set the days for hearing cases for Pleas of Land. See R.R. Sharpe, "Introduction," in Calendar of Wills Proved and Enrolled in the Court of Husting, London: Part 1, 1258-1358, ed. R.R. Sharpe (London: Her Majesty's Stationery Office, 1889). (paragraph 44 on $\mathrm{BHO}$ )
} 
easy to miss a court." ${ }^{\prime 66}$ By 1252 , the court was held in the western end of the Guildhall. ${ }^{67}$ That the Husting was limited to hearing cases only two days a week caused it to lose some business to the Sheriffs' Court; that it apparently met even less than this also caused it to lose business. ${ }^{68}$ Throughout the 1300s, the Husting increasingly became specialized, which also limited the number of cases it heard. By the mid to late 1300s, collusive recovery, a fictitious action, was the most common type of lawsuit, although the court continue to entertain cases dealing with various means of transferring land ${ }^{69}$ Even at its height, Husting, combined with the Mayor's Court, handled less than a tenth of the cases as the Sheriffs' Court. ${ }^{70}$

As part of the privileges granted to London, errors in the Husting Court could only be heard before a special court at St. Martin le Grand. Husting was also the court which heard errors in cases from the Sheriffs' Court. ${ }^{71}$ These were only entertained on the Common Pleas side of the court. Some of its most important functions included outlawing defaulters and registering official documents such as deeds, wills, and contracts. Although, by the end of the 1300s, a majority of London citizens had stopped enrolling their wills there. ${ }^{72}$ Outlawry could occur on either side, but once started had to be completed in the same side of the court. However, wills, hearings about being granted the city freedom, as well assize requests could be heard on either side of the court. That it suffered such a decline in business over the course of the fifteenth

\footnotetext{
${ }^{66}$ Tucker, Law Courts and Lawyers in London, 137. The Husting judges even had to be summoned to court, to remind them they needed to appear.

${ }^{67}$ Tucker, Law Courts and Lawyers in London, 131-32.

${ }^{68}$ It went from seventy-five cases a year, on average, in 1300 to four cases in 1430 (based on writs). Tucker, Law Courts and Lawyers in London, 144.

${ }^{69}$ Tucker, Law Courts and Lawyers in London, 105.

${ }^{70}$ Matthew Frank Stevens, "London Women, the Courts and the 'Golden Age': A Quantitative Analysis of Female Litigants in the Fourteenth and Fifteenth Centuries," London Journal 37, no. 2 (2013), 72.

${ }^{71}$ Tucker, Law Courts and Lawyers in London, 39.

72 Tucker, Law Courts and Lawyers in London, 110. Again, Sharpe does not provide a definitive date for the decline in will enrollment, although he does indicate that it had dropped prior to 1688, when no more wills were enrolled. He claims it fluctuated between zero and six wills on any given year. The highest enrollment occurred during the Black Death, between 1348 and 1349. However, he does not indicate how many wills were enrolled in those two years. Sharpe, "Introduction." (paragraph 123 on BHO)
} 
century might have had something to do with its specialization in writ-initiated actions, although the Court of Common Pleas (another writ-based court) did not seem to have the same fate. ${ }^{73}$

The Mayor's Court mostly dealt with debt and contract cases, and apprentice issues; in other words, civil pleas between citizens of London. These cases often concerned larger sums of money and those from higher socio-economic statuses than the other courts. ${ }^{74}$ However, this was not always the case. In its early tenure, the Mayor's Court was mostly regulatory in nature: it enforced city ordinances, entertained cases that dealt with city-wide issues or city officials, and regulated apprenticeships. ${ }^{75}$ Aside from cases which involved foreign merchants, the Mayor's Court was not a court of first resort at any point in the fourteenth century. ${ }^{76}$ Although anyone could ask the Mayor to hear their case, this was a grant of a request rather than a right. By the fifteenth century, however, this court had not only become the court of first resort for a variety of actions, but also served as a court of equity for London. ${ }^{77}$ Much like what probably happened with the Husting losing business to the Sheriffs' Courts, so the Sheriffs' Courts lost business to the Mayor's Court in the fifteenth century. The Sheriffs' Courts were more than likely overloaded with cases, which allowed the Mayor's Court to take over some of those cases. ${ }^{78}$

Taking a personal action from the Sheriffs' Court to the Mayor's Court began with querela levata, a writ that allowed the mayor to take a case when long delays in the lower court kept the case from being heard. Additionally, the mayor and alderman insisted that all cases

\footnotetext{
73 Tucker argues that the Court of Common Pleas did have the same issue as the Husting, but Hastings argues that the plea rolls increased in size during the fifteenth century. However, Hastings does concede that it could be the result of better record keeping rather than an increase in litigation. Tucker, Law Courts and Lawyers in London, 111; Hastings, The Court of Common Pleas in the Fifteenth Century, 8.

${ }^{74}$ Stevens, "London Women, the Courts, and the 'Golden Age'," 72; Tucker, Law Courts and Lawyers in London, 116.

${ }^{75}$ It stopped regulating apprenticeships when the Chamberlain's court was created. Tucker, Law Courts and Lawyers in London, 99.

${ }^{76}$ A court of first resort was one in which a case could initially be enrolled.

77 Tucker, Law Courts and Lawyers in London, 114; Barron, London in the Later Middle Ages, 154-55.

78 Stevens, "London Women, the Courts, and the 'Golden Age'," 72.
} 
dealing with merchant law be held in their court, because they were usually merchants themselves. Late in the 1300s, the Mayor's Court separated into two courts: the Outer Chamber, a formal court that operated in public and the Inner Chamber, an informal court which was held behind closed doors. ${ }^{79}$ The Mayor's Court was more expensive to access than the Sheriffs' Court, so the cases it entertained were often ones with more money at stake or higher-status litigants. ${ }^{80}$ Additionally, it was available to hear cases on any day of the week, including Sundays. More than likely, this was because it specialized in merchant-oriented cases where defendants or plaintiffs might need to leave town on business. ${ }^{81}$ Unfortunately, most of the records for the early fifteenth century are lost, and evidence comes from mentions of cases in the plea and memoranda rolls. Using these records, Tucker calculates that "debt probably constituted between 50 and 60 per cent of all personal pleas, with trespass constituting about 15 per cent." 82 This was far different from the composition of cases in the third major court of London, the two sheriff's courts.

The final local court available to Londoners were the Sheriffs' Courts. There were two sheriffs for London, and they served as both royal and city servants. It is perhaps fortuitous that this was the case as the local records of the sheriffs' activities are woefully incomplete. Each sheriff was responsible for their own records and at the end of their term, they were supposed to turn those over to the city government; the majority did not. However, references to cases held before the Sheriffs' Court survive in the plea and memoranda rolls of the Mayor's Court and

\footnotetext{
79 The Inner Chamber became the Court of Requests in the sixteenth century. The Outer Chamber probably heard cases in the west end, same as Husting, while the Inner Chamber sessions were probably heard upstairs. Tucker, Law Courts and Lawyers in London, 112-14.

${ }^{80}$ Tucker, Law Courts and Lawyers in London, 116; Stevens, "London Women, the Courts, and the 'Golden Age'," 72.

${ }^{81}$ Tucker, Law Courts and Lawyers in London, 138.

${ }^{82}$ Tucker, Law Courts and Lawyers in London, 149-50.
} 
various central courts. ${ }^{83}$ Despite the lack of records, Barron explains that "the sheriffs' court may have been the oldest and was probably the busiest judicial court in the city." 84 Both Matthew Frank Stevens and Tucker have estimated that the courts heard in the vicinity of 4,000 cases each year. ${ }^{85}$ To handle this volume, each sheriff had their own court and each court held two sessions per week: one at the respective office (counter) of each sheriff and one at the Guildhall in the west end. ${ }^{86}$ While merchant law cases had definitively moved to the Mayor's Court during the later 1300s, the Sheriffs' courts were still the main city court for litigation well into the sixteenth century. ${ }^{87}$

In addition to the courts they held, the sheriffs of London were responsible for the city's prisoners, who were held at five of the ten London prisons: Newgate, the oldest and most infamous, Ludgate, the Tun, and the two sheriff's counters: Poultry Street and Bread Street. ${ }^{88}$ They also held a court for non-citizens, usually on Mondays, but as was the case for the Mayor's Court they met whenever they needed to in order to accommodate any travel. ${ }^{89}$ The Sheriffs' Court also did not abide by the standard law terms as seen in the central courts; it met year round. While the ratio of debt to trespass cases were similar to the Mayor's Court in the 1320s, it seems likely that by the early fifteenth century, trespass cases were either equal to or higher in number than debt cases. ${ }^{90}$ In addition to the civil litigation, the Sheriffs' Court handled upwards

\footnotetext{
${ }^{83}$ Stevens, "London Women, the Courts, and the 'Golden Age'," 73.

${ }^{84}$ Barron, London in the Later Middle Ages, 163.

85 Stevens, "London Women, the Courts, and the 'Golden Age'," 72; Tucker, Law Courts and Lawyers in London, 159.

86 Tucker, Law Courts and Lawyers in London, 132.

87 Tucker, Law Courts and Lawyers in London, 130.

${ }^{88}$ Winter, "Prisons and Punishments in Late Medieval London," 52. The ten prisons in and around London in the fifteenth century were Fleet, Ludgate, Newgate, Bread Street, Poultry Street, the Tun, the Tower, the Marshalsea of the Household, the Marshalsea of the King's Bench, and the Clink. Fleet, the Tower, the two Marshalsea prisons, and the Clink held royal prisoners. Winter, "Prisons and Punishments in Late Medieval London," 49, 52; Barron, London in the Later Middle Ages, 164, 167.

${ }^{89}$ Tucker, Law Courts and Lawyers in London, 140.

90 Tucker, Law Courts and Lawyers in London, 153. As previously described, the records are completely lost for most of the fourteenth and fifteenth centuries. Tucker put these statistics together using references to cases in the
} 
of 1,000 misdemeanor cases each year, although all crimes of a sexual nature were handled in the Mayor's Court. ${ }^{91}$ From this information, it seems likely that trespass cases concerning violence between the poorer London residents were heard in either the Sheriffs' Court or at wardmote inquests, and only those who could afford the fees of the central court took their cases to the Court of the King's Bench or the Court of Common Pleas.

\section{Court of the King's Bench}

The Court of the King's Bench was the preeminent court in which someone could pursue a misdemeanor or felony for England. In its early days the judges often moved with the king during his long journeys from the capital. Originally this court was headed by the king himself, but the Angevin reorganization of the legal system subtly altered how the Court of the King's Bench operated. It began development, alongside the Court of Common Pleas, around 1215 with the creation of the Magna Carta. One of the major complaints of the barons during King John's reign (r. 1199-1216) was the lack of consistent courts to hear cases. Itinerant justices were not listening to cases as frequently as they once did, thus delaying justice and recompense.

Therefore, the barons demanded consistent courts in a fixed location, leading to the development of the two courts. ${ }^{92}$ Over the subsequent two centuries, those between Henry III's reign (r. 12161272) and 1405 during Henry IV's reign (r. 1399-1413), the Court of the King's Bench continued to evolve and develop. The Coram Rege rolls, or plea rolls, reflect the fiction that the court was held before the king, when, instead by 1234 , cases were heard before royally appointed judges ${ }^{93}$ By the fifteenth century, it had settled permanently in Westminster Hall, close to the

central courts as well as comparisons to the Mayor's Court.

${ }^{91}$ Tucker, Law Courts and Lawyers in London, 156.

${ }^{92}$ Baker, An Introduction to English Legal History, 23.

${ }^{93}$ According to Ralph Turner, there was only one royally appointed judge in 1234 and this increased first in 1240 and again over the intervening centuries. "The Origins of Common Pleas and King's Bench," American Journal of Legal History 21, no. 3 (1977), 250; Hastings, The Court of Common Pleas in the Fifteenth Century; Blatcher, The 
bustling metropolis, a portion of whose population was not only employed by the courts, but were also litigants in them. During the fifteenth century, both the Court of the King's Bench and the Court of Common Pleas were still solidifying their scope and role in the common law system, fighting each other and local courts for jurisdiction.

Common law courts with royally appointed justices consisted of a variety of courts, both local and central. To simplify a fairly complex concept, common law refers to the law that was customary or traditional to England. ${ }^{94}$ It was based on the Statutes of the Realm and could be amended by court practice. ${ }^{95}$ The central courts under the common law system, meaning those which operated solely out of Westminster Hall, consisted of the Exchequer of Pleas, the Court of the King's Bench, and the Court of Common Pleas. The Exchequer was a court that heard cases in which someone owed money to the crown. It was supposed to be restricted to royal officials in terms of bringing a case, but the legal fiction of the writ of quominus allowed private subjects to use the court as well. ${ }^{96}$ The Court of the King's Bench heard mostly misdemeanors and felonies, had oversight over criminal proceedings from lesser courts, and was the court of first instance for Middlesex county. However, it could also entertain civil pleas and throughout the fifteenth and sixteenth centuries it was in stiff competition with the Court of Common Pleas over rights to certain cases. ${ }^{97}$ One of the reasons for this competition between courts was that the costs of appealing or appearing went directly to the court in which a case was heard. The Court of Common Pleas only heard civil actions, with few exceptions, and had oversight over civil

Court of the King's Bench; Paul Brand, and Joshua Getzler, eds. Judges and Judging in the History of the Common Law and Civil Law (Cambridge: Cambridge University Press, 2012); See Brundage, The Medieval Origins of the Legal Profession for more on the professionalization of the justice system.

${ }^{94}$ Tucker, Law Courts and Lawyers in London, 32-33.

${ }^{95}$ Dryburgh, "The Law and Legal Records."

${ }^{96}$ Dryburgh, "The Law and Legal Records."

${ }^{97}$ Blatcher, The Court of the King's Bench, 7-8. 
proceedings from lesser courts. ${ }^{98}$ Anyone who sued for a debt over forty shillings had to do so in the Court of Common Pleas. ${ }^{99}$

On average, the Court of the King's Bench entertained a little over 800 cases per term. ${ }^{100}$ It was never as busy as the Court of Common Pleas as it only averaged about thirteen percent of the cases heard before its sister court. It also had oversight for all criminal proceedings from lesser courts, such as those discussed in the preceding pages. However, for London, most appeals were heard in a special session of royal justices held at random intervals at St. Martin le Grand, an area that was considered neutral ground by both the royal and London governments. ${ }^{101}$ Most of the cases heard before the Court of the King's Bench were appeals, with the majority being misdemeanor or trespass cases. ${ }^{102}$ It is these that were probably also pursued as trespasses within other courts, such as the Court of Common Pleas. As the Court of the King's Bench was the court of first instance for Middlesex, but not London, many of the cases enrolled in its records were from that county, with cases from other counties being heard first by the local royal courts at gaol delivery or the assizes. After the series of reforms implemented in the thirteenth and fourteenth centuries, most cases concerning felonies and misdemeanors were heard in front of, and decided on by, a jury of peers, with a panel of judges overseeing the proceedings. And while felonies had to be heard in front of royal justices, misdemeanors did not.

\footnotetext{
${ }^{98}$ Euan Rogers, "The Court of Common Pleas," Postgraduate Archival Training (PAST): Medieval Legal Records Workshop, The National Archive (2018).

${ }^{99}$ That is, of course, unless they were a Londoner suing another Londoner as this was one of the unique privileges granted to London in its charter.

${ }^{100}$ This number was extrapolated from the count of entries performed by William Holdsworth. See A History of English Law, Vol 4, 255.

101 Tucker, Law Courts and Lawyers in London, 34. It was a liberty outside of city jurisdiction. Shannon McSheffrey, Seeking Sanctuary: Crime, Mercy, and Politics in English Courts, 1400-1550 (Oxford: Oxford University Press, 2017), 119-22; Barron, London in the Later Middle Ages, 35.

102 The major difference between misdemeanors and felonies was the risk to the defendant. Misdemeanors could not have life or limb punishments and the exact punishment was up to the judge. Felonies were proscribed a punishment of death by hanging, although the convicted criminals were at the king's mercy. Trespass, used in the civil sense, only resulted in a monetary payout. Baker, An Introduction to English Legal History, 584-85.
} 
Procedures within the courts varied between the different systems. One of the more prominent differences was the terminology used in the courts. Misdemeanors and felonies used criminal procedures, while civil procedures were used for trespasses, which dealt with torts, or wrongs. ${ }^{103}$ The actions themselves could be the same: a theft, for example, could be pursued with either type of procedure and often in front of the same justices. Within the justice system, the type of crime influenced the court in which it was appealed. ${ }^{104}$ Felonies could only be heard in a court headed by a royally appointed judge whereas a misdemeanor could be heard by any judge. Most civil cases could be appealed in any court, with one limitation: debts under forty shillings did not need a writ, while debts over forty shillings did. ${ }^{105}$ Indeed, the need for writs was a cornerstone of the civil system at the central level. ${ }^{106}$ Juries usually decided cases regardless of the type of procedure they used (criminal or civil) and in neither was there a court reporter. Most legal records consist of the pleas and judgments rather than the words said in court. ${ }^{107}$ The records that remain for the Court of the King's Bench are not the trial transcripts, but rather reflect the formal processes of the case. Trials were rarely recorded verbatim as seen in courts today. ${ }^{108}$ The trial itself would have occurred in at least two different languages, Law French and English, and the case was recorded in a third language, Latin. ${ }^{109}$ The rolls were divided between

\footnotetext{
${ }^{103}$ Misdemeanors were any crime where no life or limb punishment could be enacted. Whereas a felony was a capital offense. I use misdemeanor in lieu of trespass in order to distinguish the civil from criminal procedures of the courts. Baker, An Introduction to English Legal History, 572.

${ }^{104}$ Appeal is used here in the sense of accusing another of a crime, not in the modern sense of officially questioning the verdict to a higher court.

${ }^{105}$ Beckerman, "The Forty-Shilling Jurisdictional Limit," 111. This was, according to Beckerman, strictly enforced. He does not, however, find any such restriction for trespass cases: "Thus, chapter eight of the Statute of Gloucester did not limit the jurisdictions of local courts to claims of under $40 \mathrm{~s}$ in pleas of trespass, and if the plea rolls are to be believed, no one in the late thirteenth or fourteenth centuries interpreted the statute as having done so." Beckerman, "The Forty-Shilling Jurisdictional Limit," 113.

${ }^{106}$ Details on the procedures for a civil plea are given later in the chapter.

${ }^{107}$ In some courts and cases, witness statements were recorded, but not during the trial. These are more like modern depositions. Baker, The Oxford History of the Laws of England, Vol. 6, 363-64.

${ }^{108}$ Baker, An Introduction to English Legal History, 581.

109 J.H. Baker, "The Three Languages of the Common Law," Mc Gill Law Journal 43 (1997), 7.
} 
pleas, those cases brought by appeal, and crown, those cases brought by indictments.

These were the two ways in which a felony, misdemeanor, or trespass could come before the court: an appeal (through the use of Chancery writs) and an indictment (from a grand jury). ${ }^{110}$ In an appeal, either the victim (or in the case of death, the victim's kin) made a formal accusation against the alleged perpetrator. However, the more common method was through an indictment. ${ }^{111}$ There were a variety of ways someone could be indicted for a wrong-doing: a selection of men from the area could present the crime to the court, otherwise known as presentment juries. Juries at coroner's inquests could also return indictments. The men serving on these juries were often the same as the ones for trial, although each jury had a unique function. At the assizes, a group of men were appointed to examine other juries' indictments; eventually they became known as a grand jury in order "to distinguish it from trial juries." 112 Presentment juries, coroner's inquest juries, or grand juries did not decide guilt or innocence. The first simply told the court of any crimes or possible criminals from their village or hundred. ${ }^{113}$ The latter two decided whether a crime had occurred that should be tried in a court of law. ${ }^{114}$ English trials in the late Middle Ages were not lengthy affairs; as John Baker explains, misdemeanor trials usually lasted around five to ten minutes and a felony trial was often less than thirty minutes. ${ }^{115}$ Witnesses were sworn in to give evidence against the defendant who was not allowed to have an attorney. Witnesses for the defense were not sworn in nor were their

\footnotetext{
110 The appeal for local courts could be by oral account or written bill, but for the King's Bench it had to be a Chancery writ. Sean Cunningham, "The Court of the King's Bench," Postgraduate Archival Training (PAST): Medieval Legal Records Workshop, The National Archives (2018).

111 Baker, An Introduction to English Legal History, 573.

112 Baker, An Introduction to English Legal History, 576.

113 A hundred court belonged to the administrative unit of the 'hundred' which theoretically consisted of 100 men, one man per hide. A hide was considered the amount of land needed to sustain a family; this amount varied based on location. A shire (or country) consisted of an average of twelve 'hundreds'. Harding, The Law Courts of Medieval England, 17-18.

114 Baker, An Introduction to English Legal History, 577.

115 Baker, An Introduction to English Legal History, 582. Philippa Maddern also found a similar pattern of short trials in the legal records she consulted. Maddern, Violence and Social Order, 54, 59-60.
} 
statements held in the same regard as those of prosecution witnesses. However, despite these disadvantages, a defendant could challenge up to thirty-five jurors and those on the jury had to unanimously agree to a guilty verdict, otherwise the defendant was acquitted. ${ }^{116}$ Additionally, an acquittal was final and could not be overturned. ${ }^{117}$ These trials could occur in either a local court or a central court.

Choosing a court in which to pursue a case could be a fraught venture for a medieval Londoner. Some acts lent themselves to certain courts. For example, murder was never pursued using civil procedures as it was a felony. However, other acts, such as assault or theft, were less clear cut. An act of trespass, which included violent acts like assault and abduction (or using force and arms to steal twenty trees as happened in the case which opened this chapter), could be pursued using either criminal or civil procedures as they were also considered misdemeanors. In fact, for the Court of the King's Bench, a victim might pursue an assault as a misdemeanor or a trespass. ${ }^{118}$ Trespass was one of the major actions shared by the Court of the King's Bench and the Court of Common Pleas. There were a variety of rules that governed felonies and misdemeanors in terms of which courts or types of justices (royal or not) could hear them, but the same was not true for civil actions. For the most part, which court a civil suit would go to depended on whose peace had been broken: the king's, a local lord's, shire's, or city's. ${ }^{119}$ As the

\footnotetext{
${ }^{116}$ Challenging jurors in the medieval court room was not unlike what happens in a modern court room. Perhaps the biggest difference was that there was a thirty-five-person limit to preemptory challenges in the medieval system, meaning one did not have to provide a rationale for any of the challenges. Baker, An Introduction to English Legal History, 580-81.

${ }^{117}$ Baker, An Introduction to English Legal History, 581-82. Conclusion rates for cases in my dataset were low: eight out of eighty-two cases (9.7 percent). Of those, four were decided in favor of the plaintiff, one was decided in favor of the defendant, and three were dismissed because the plaintiff defaulted, meaning they failed to appear in court.

${ }^{118}$ While cross-suiting, or using multiple courts at once, was a common enough occurrence, I could find no evidence of victims in my dataset pursing a violent act as both a trespass and misdemeanor in the court records held by the London Metropolitan Archives. Of course, these litigants may have pressed suits in other central courts, such as the King's Bench or the records may not have survived.

119 Teresa Phipps, "Misbehaving Women: Trespass and Honor in Late Medieval English Towns," Historical Reflections 43, no. 1 (2017), 64.
} 
judges of the Court of the King's Bench and the Court of Common Pleas continued to fight over jurisdiction, those who were wronged enjoyed a plethora of courts in which to pursue justice.

However, they had to make an important decision, whether to pursue the violent act as a

misdemeanor or as a trespass. For many, it came down to what the plaintiffs wished to achieve by initiating a case, which court they thought would give them the best advantage, and what they might afford: the Court of the King's Bench or the Court of Common Pleas.

\section{Court of Common Pleas}

The Court of Common Pleas, otherwise known as the Court of Common Bench, was the preeminent court using civil proceedings in England and it had two areas of purview: first, common law on private actions (person to person, litigation) and second, privilege on two types of cases. ${ }^{120}$ It had the privilege of hearing misdemeanor or felony cases that arose out of pleas in front of the Court of Common Pleas and any case involving its officers. ${ }^{121} \mathrm{~A}$ third purview of the Court of Common Pleas was rarely used: it was also the supervisory court of lesser courts. It began operation sometime in the early thirteenth century. Historians dispute the exact date, but most agree that by 1237 it was a fully implemented court system. ${ }^{122}$ The justices for the Court of Common Pleas remained in Westminster, which was to the west of London, and heard cases in Westminster Hall, in the northern part of the Great Hall. ${ }^{123}$ Increasingly, Londoners viewed the Court of Common Pleas as a de facto London court and used it as such; this, despite the

\footnotetext{
${ }^{120}$ Privilege meaning the right to hear a case even if it should otherwise be in front of another court. I outline the four main private actions used before the court on page 29. In brief, these were 1) Personal Actions, 2) Real Actions, 3) Mixed Actions, and 4) Trespass Actions.

${ }^{121}$ Hastings, The Court of Common Pleas in the Fifteenth Century, 19.

122 Baker, An Introduction to English Legal History, 21; Jonathan Mackman, and Matthew Frank Stevens, "Introducing the Common Pleas." Court of Common Pleas: The National Archives, CP40: 1399-1500 British History Online (2010): http://www.british-history.ac.uk/report.aspx?compid=119287; The National Archives, "Records of the Court of Common Pleas and Other Courts." http://discovery.nationalarchives.gov.uk/details/r/C61.

${ }^{123}$ Hastings, The Court of Common Pleas in the Fifteenth Century, 28.
} 
prohibitions against Londoners suing each other outside of London courts. ${ }^{124}$ All cases before the Court of Common Pleas were civil actions, between private individuals, whereas the Court of the King's Bench mostly handled felonies, misdemeanors, and cases where the king had an interest. ${ }^{125}$ Even after the creation of these two courts, itinerant justices continued hearing cases around the country in assize and county courts.

As the court which refined civil litigation in England, the Court of Common Pleas has no equal. Looking back through the years, the system may seem overly complex and rigid: writs had to be precisely worded, cases had to be pleaded by specialists, narratives forced into legal language that fit the action and writ categories, and everything came at a cost to the litigants. The Court of Common Pleas had between four and eight justices, three prothonotaries, and eight or nine serjeants at law. ${ }^{126}$ However, the court did not usually try or judge cases. Instead, the justices and serjeants at law of this court would help determine what the juries would decide when the case went to trial in a local assize court. Cases enrolled in the Court of Common Pleas could take years to resolve, with the stages of a case repeating through various pleadings or being dragged out by litigants throughout the mesne process. Civil suits at the central level had more restrictions than those at the local level and this dissertation focuses on cases before the central Court of Common Pleas; however, more often than not, basic processes aligned between the two types of courts. In some instances, those procedures varied depending on the type of suit, not every writ allowed plaintiffs to request damages, for example. Very few cases on the rolls of

\footnotetext{
${ }^{124}$ Matthew Frank Stevens, "Londoners and the Court of Common Pleas," in London and Beyond: Essays in Honour of Derek Keene, ed. Matthew Davies, and James A. Galloway (London: Institute of Historical Research, 2012), 244.

125 Baker, An Introduction to English Legal History, 21; Mackman, and Stevens, "Introducing the Common Pleas."

${ }^{126}$ During the fifteenth century it probably had six judges and three prothonotaries. A prothonotary is a chief clerk, in charge of lesser clerks and recordings of the court proceedings. Hastings, The Court of Common Pleas in the Fifteenth Century, 59.
} 
the Court of Common Pleas ever reached a conclusion, at least one recorded by the courts. ${ }^{127}$

Private actions heard before the Court of Common Pleas encompassed four main

jurisdictions, with several subcategories: real actions, personal actions, mixed actions, and

trespass. ${ }^{128}$ While the majority of suits on the rolls of the Court of Common Pleas concerned

debt, which fell under personal actions, for this dissertation, I only use cases classified as

trespass vi et armis. Stevens argues that a significant number of Londoners used the Court of

Common Pleas as a court of first resort for these "violence-related lawsuits." 129 Trespass actions

could be heard in either the Court of the King's Bench or the Court of Common Pleas and it was

up to the Chancellor, the head of the Court of Chancery, to assign the court during the process of

issuing the original writ. ${ }^{130}$ Since local courts could also entertain civil actions, plaintiffs made a

decision as to the level and type of court in which they wanted to bring their suit. ${ }^{131}$ For cases of

debt and detinue, there were restrictions placed on litigations, but the same was not true for

trespass actions. ${ }^{132}$ Depending on the value of goods and the damages, court costs from the Court

of Common Pleas might make it more lucrative to sue in a lower court; as John Beckerman

asserts, "for large sums, however, of 40s. or more, it was profitable to exact part of the proceeds

${ }^{127}$ Again, only eight out of eighty-two cases (9.7 percent) reached a conclusion. For the larger dataset, 141 out of 974 cases (14.4 percent) reached a conclusion. These were not all in favor of the plaintiff. While the rest of the cases offer no resolution, it is likely that many of the litigants reached out of court settlements, possibly through

arbitration. I will discuss this more in chapter three.

${ }^{128}$ I discuss these actions in more detail on page 29 in chapter one.

${ }^{129}$ Stevens, "Londoners and the Common Pleas," 239.

${ }^{130}$ Hastings, The Court of Common Pleas in the Fifteenth Century, 24.

${ }^{131}$ Some may have cross-suited, or forum shopped, meaning they enrolled the case in more than one court in order to see which one gave them the best chance of gaining the desired outcome. However, this would also have been costly and possibly time consuming.

132 There was an upper limit of forty shillings in local courts for debt, anything above forty shillings needed a writ, but the same was not true of trespass cases. John Beckerman shows evidence that the Statute of Gloucester (1278) simply said the central courts would ONLY hear cases dealing with moveable property worth more than forty shillings, not that one HAD to use the central court. Idea behind this was to not only discourage 'trivial' suits, but also to make more money. "The Forty-Shilling Jurisdictional Limit." Detinue was an action that dealt with the theft of moveable property, i.e. goods; it is different from theft as a trespass action because with detinue the demandant was attempting to regain their goods, whereas in theft, the plaintiff sought damages and cost recompense only. 
in return for the aid of the court in recovering the debt." 133

Most of the cases that came before this court dealt with debt and this may be because of a rule from the 1278 Statute of Gloucester that said that any person attempting to collect a debt of more than forty shillings had to do so in the Court of Common Pleas. ${ }^{134}$ While this 'forty-shilling rule,' as it became known, did not apply to other types of torts, like trespass, it is easy to see from a sampling of cases that not many individuals came before the court asking for less than two pounds (or forty shillings). ${ }^{135}$ The 'forty-shilling rule' applied to the cost of the wrong to the plaintiff; what was meant by the "cost of the wrong" was the value of the goods stolen or the amount of the original debt. This resulted in many debt cases appearing in local court records for thirty-nine shillings and eleven and a half pence, so one half-pence under the limit. Beckerman posits that this was to avoid the cost of a writ for a debt that was not too much over the fortyshilling limit. ${ }^{136}$

This reticence by plaintiffs to sue in central courts over smaller sums is consistent with the idea that the Court of Common Pleas, along with all royal courts, was quite expensive to access. The cost to access, of course, does not include the cost of any lawyers or the cost of the serjeants at law. In order to bring a case before the Court of Common Pleas, litigants had to get an original writ from Chancery. ${ }^{137}$ The cost of this writ was a percentage of the debt or damages requested. ${ }^{138}$ This writ caused the defendant to be arrested by the local sheriff and they then had

\footnotetext{
133 Beckerman, "The Forty-Shilling Jurisdictional Limit," 112.

${ }^{134}$ Beckerman, "The Forty-Shilling Jurisdictional Limit." Although this changes with the introduction of the Bill of Middlesex by the King's Bench in the mid-1400s; after this, the Court of Common Pleas steadily loses business to the King's Bench as the Court of Common Pleas became a more expensive court to use.

135 This rule did not apply to London.

136 Beckerman, "The Forty-Shilling Jurisdictional Limit," 111-12.

137 As previously stated, this cost four pence. Tucker, Law Courts and Lawyers in London.

${ }^{138}$ Hastings, The Court of Common Pleas in the Fifteenth Century, 160-161. Although this applied to other local courts in England, it was not true for London. In London city courts, defendants were arrested for trespass cases.
} 
to pay a fee to stay out of custody and to ensure they would appear before the court. ${ }^{139}$ Some of the vi et armis trespass cases used in this dissertation did take place between Londoners; however, most did not. ${ }^{140}$ This means those Londoners would have wanted the power of this royal writ to force the appearance of a non-Londoner in court. The same could be true of nonLondoners suing Londoners; depending on where the initial event occurred, they might have traveled quite a way and would have wanted to ensure the appearance of the defendant(s). Once this writ had been successfully delivered, the long process of getting both litigants to court and ready to plead began: this was known as the mesne process.

While the mesne process for the Court of Common Pleas could take up to a year and a half, defendants were consistently forced to appear and therefore a case could proceed more quickly than in a local court. ${ }^{141}$ Of the 6,000 entries in one plea roll, 5,000 of them were about the mesne process. ${ }^{142}$ Indeed, most of the business of the court (that of the mesne process) did not take place before the justices, but rather outside of court through the prothonotaries, filicers, and attorneys. ${ }^{143}$ All of these officials, especially the justices, serjeants at law, prothonotaries and filicers, were highly trained in the law and processes of the courts. ${ }^{144}$ That most law students learned procedure by visiting and watching and studying the Court of Common Pleas and its

\footnotetext{
139 This is similar to modern notions of bail.

${ }^{140}$ Of the eighty-two cases, only four listed both the plaintiff and defendant as being from London. TNA, CP 40/598, rot. 431; TNA, CP 40/598, rots. 104-105(d); TNA, CP 40/599, rot. 548; TNA, CP 40/618, rot. 136d. In total, only ten cases explicitly identified either the plaintiff or defendant (or both) as being from London. For plaintiffs, see TNA, CP 40/590, rot. 231d; TNA, CP 40/594, rot. 499; TNA, CP 40/619, rot. 520. For defendants, see TNA, CP 40/605, rots. 318-318d; TNA, CP 40/615, rot. 445; TNA, CP 40/619, rot. 359. This does not mean, however, that none of the other cases did not involve Londoners, just that they were not identified as being from London in the records.

${ }^{141}$ I will explain more about the process of a suit in the next section, but the mesne process included all the intermediate steps between the original writ and the appearance of the defendant (or their attorney) before the court.

142 Hastings, The Court of Common Pleas in the Fifteenth Century, 9.

${ }^{143}$ It was not uncommon for these court officials to use the churches in Western London to conduct their business. serjeants at law seem to have used St. Paul's, while the prothonotaries and filicers used whatever church was selected by the chief justice at the time. Hastings, The Court of Common Pleas in the Fifteenth Century, 38-39.

${ }^{144}$ Hastings, The Court of Common Pleas in the Fifteenth Century, 59. There were over one hundred men who worked for the court although only the attorneys and clerks were considered officers of the court.
} 
records is an indication of how important it was to the legal systems of England. ${ }^{145}$ While suing in the Court of Common Pleas was costly, the expertise of the men who worked for the court was second to none. Litigants who chose to sue in the Court of Common Pleas employed men who had been studying law almost twenty years by the time they were allowed to plead in front of the justices as a serjeant at law. ${ }^{146}$ This level of expertise might have been quite attractive to plaintiffs, although it also benefited the defendants. These men knew the nuances of law and litigation like no other in England, except perhaps the justices sitting on the bench; those justices would have been chosen from among the serjeants at law. ${ }^{147}$

Of course, the men learning law at the Inns of Court and by watching and studying the proceedings in the Court of Common Pleas did not only practice law in that court. ${ }^{148}$ These men worked as attorneys in their home counties, in London or for other city courts, and more than likely many of them worked for the other central courts. Some courts, that eventually took cases from the Court of Common Pleas, were not involved in civil litigation of the same type as the Court of Common Pleas in the fifteenth century, like Chancery. Others, like the equity courts, were not developed until after the fifteenth century. ${ }^{149}$ While the Court of the King's Bench

\footnotetext{
${ }^{145}$ Observing the Court of Common Pleas was a part of formal legal training at the Inns of Court. See chapters five and six in Hastings, The Court of Common Pleas in the Fifteenth Century. for more details on the training of court personnel. See Baker, The Third University of England; Brundage, The Medieval Origins of the Legal Profession. for general overviews on legal training.

${ }^{146}$ Hastings, The Court of Common Pleas in the Fifteenth Century, 64.

${ }^{147}$ Hastings, The Court of Common Pleas in the Fifteenth Century, 61.

148 Throughout the fifteenth century, Inns of Court were divided into four main Inns: Gray's Inn, Lincoln's Inn, Inner Temple, and Middle Temple. There were also ten minor Inns, the Inns of Chancery, which operated under the auspices of one of the four main inns. While some might have gone to Oxford or Cambridge to learn the law, most of the men working in the Court of Common Pleas in the fifteenth century began their legal education by attending one of the ten Inns of Chancery. At one of the Inns of Chancery, a student would study the original writs and forms for probably one to two years. Once they had mastered the basic principles of law, they could then apply to attend one of the greater Inns. Hastings, The Court of Common Pleas in the Fifteenth Century, 62-64; "Inns of Chancery." Gray's Inn https://www.graysinn.org.uk/history/inns-chancery. For excellent overviews of legal training in the Middle Ages, see Brundage, The Medieval Origins of the Legal Profession, 218-281, 367-369; Baker, The Third University of England.

${ }^{149}$ The Court of Chancery could and did hear trespass suits, even ones alleging trespass vi et armis, however, this was only after the case had begun in another court. Using a formal petition to the chancellor (the judge for Chancery), a litigant could allege corruption at the lower court and get their case removed to Chancery for a 'fair
} 
might have been a cheaper venue during the latter part of the fifteenth century, the Bill of Middlesex was not as developed or as frequently deployed in the first half of the century. Most private actions heard by the Court of the King's Bench would still have been writ-based, which negated some of that cost saving. Litigants in the Court of the King's Bench would also not have had to employ a serjeant at law to plead their case, which also cut the cost of using that court. However, the expertise of the serjeants at law in the Court of Common Pleas might have seemed beneficial to litigants. In addition, the procedures for litigation were well established, so while the Court of the King's Bench may have been the superior court in standing, it was the inferior court when it came to civil litigation.

Beginning with the original writ, plaintiffs suing in the Court of Common Pleas accrued costs. The fee for sealing the original writ from Chancery was six pence, which when added to the fee paid to the clerks would cost the plaintiff at least seven shillings and two pence. The fee paid to the clerks was a percentage of the value of the suit, the more valuable the debt or goods or damages, the more money paid. ${ }^{150}$ For example, when Richard Nyweport sued Odo of Ulmis for 1,000 marks in damages, he probably paid roughly sixty seven pounds to Chancery just for the original writ. ${ }^{151}$ Every time a plaintiff had a writ sealed or delivered or entered into the plea rolls, they paid a fee. Most cost between two and four shillings, but that adds up over time. If a plaintiff needed to go through the process of outlawry, each of those writs cost around six pence. Copies of writs, pleas, and other entries, which a careful litigant would maintain, cost anywhere

trial'. Harding, The Law Courts of Medieval England, 100-101.

150 The standard fee for a forty pound value of damages would have been six shillings and eight pence. It is unclear what was paid by litigants with cases valued under forty pounds. Anything above forty pounds was assessed a fee of "roughly one two-hundredth of the value of the thing demanded" Hastings, The Court of Common Pleas in the Fifteenth Century, 161.

${ }^{151}$ One mark was thirteen shillings and four pence, so 1000 marks was 666 pounds, thirteen shillings, and four pence. TNA, CP 40/601, rot. 139. 
between two and twenty pence, depending on the length of what was being copied. ${ }^{152}$ This does not include the fees paid to the serjeants at law for pleading their cases, which litigants on both sides had to pay. ${ }^{153}$ In Fox v. Fancoby, the case from the beginning of the chapter, Fox paid at least seven shillings and two pence, but more than likely paid one pound, three shillings, and two pence just for the written documents; this total would rise because he would also have to pay the serjeant at law to plead the case on his behalf. In total, a plaintiff would have had to pay at least two pounds and possibly more than seventy pounds, depending on the cost of the original writ.

Two pounds may not seem like a lot to modern sensibilities, but for the average person in the fifteenth century, it was a hefty sum; two pounds might equal the yearly wages for a laborer or the cost of a year's attendance at university. ${ }^{154}$ The costs associated with a suit in the Court of Common Pleas suggests that a person had to be serious in their quest to obtain restitution for the violence done to them or their property. Indeed, the procedures required also suggest a level of seriousness and commitment to a case. Frivolous lawsuits would have been for the wealthiest of people, but even then, it seems unlikely they would waste their time and resources on a case they did not think they at least had a chance of winning. The Court of Common Pleas seemed to have set prices to ensure that only those serious would pursue a case in front of their court. ${ }^{155}$ However, the English continued to be litigious, as indicated by the court records of the fifteenth century.

\footnotetext{
152 Detailed lists of these costs can be found in Hastings, The Court of Common Pleas in the Fifteenth Century, 25155.

${ }^{153}$ While it is unclear the exact amount charged by serjeants at law, they were often exhorted to not overcharge. To retain a serjeant to plead his cases, the king usually paid twenty pounds a year, although by the mid-fourteenth century, that price had increased to forty pounds a year. J.H. Baker, The Order of Serjeants at Law: A Chronicle of Creations, with Related Texts and a Historical Introduction (London: Selden Society, 1984), 59, 379.

${ }^{154}$ See lists compiled at "Medieval Price List" by Kenneth Hodges, http://medieval.ucdavis.edu/120D/Money.html. ${ }^{155}$ Indeed, this was one of the reasons for the Statute of Gloucester (1278) - to reduce the number of low-stakes lawsuits being filed in the court. Beckerman, "The Forty-Shilling Jurisdictional Limit."
} 


\section{The Life of a Case}

For the Court of Common Pleas, there were four parts of a civil action, which litigants used to gain redress for the tort. First, plaintiffs would obtain an original writ from the Court of Chancery. ${ }^{156}$ The original writ assigned jurisdiction to the Court of Common Pleas and explained the charges laid against the defendant. This was highly formulaic language, which included the most pertinent information: names, places of residence, cause of action, and the place of occurrence. ${ }^{157}$ As all the cases used in this dissertation have reached the third stage (pleading), the original writ makes up the first three or four lines of the case. ${ }^{158}$ However, for other cases, this may be the only information contained in the records. During the early fifteenth century, occupation was added to this list of pertinent information. ${ }^{159}$ Having obtained the original writ, the plaintiff then delivered the writ to the appropriate sheriff, the one in whose county the wrong had allegedly occurred. After the original writ was returned to the Court of Common Pleas, the justices issued a writ of capias or distringas. This was a procedural writ used in trespass actions. Both the original writ and the procedural writs were designed to force the appearance of the defendant in court, namely the central court. ${ }^{160}$

Once the writ was delivered to the defendant, the second part of a civil action began, the

\footnotetext{
${ }^{156}$ I use plaintiff here and throughout my dissertation because the torts I consider are those where the person is complaining about a wrong done to them (plaintiff), rather than demanding a right be restored to them (demandant). Baker, An Introduction to English Legal History, 67-68.

${ }^{157}$ A generic formula for a trespass plea would look like this: [Name of Defendant] was attached to answer [Name of Plaintiff] in a plea why with force and arms they [type of tort] in [location of the wrong] and other wrongs against them to the grave damage of the same [Name of Plaintiff] and against the peace of the king etc. Of course, this would be in Latin in the Court of Common Pleas rolls. For the Fox v. Fancoby case from the beginning of the chapter, it looked like this: "Thomas Fancoby corsour attachiatus fuit ad respondendum Richardo Fox de placito quake vi et armis clause et demos ipsius Ricardi apud suburbium London fregit et arbores suas ad valenciam decem librarum ibidem nuper crestentes succidit et asportavit et alia enormia ei intulit ad grave dampnum ipsius Richard et contra paces Regis, etc." TNA, CP 40/603, rot. 483d.

${ }^{158}$ See Image 2 page 227 for an example of what this looks like on a plea roll of the Court of Common Pleas.

${ }^{159}$ See the Statute of Additions in 1413 (1 Hen. V, c. 5), as printed in The Statutes of the Realm, vol 2: 1377-1504 (London: 1816), 171.

${ }^{160}$ Hastings, The Court of Common Pleas in the Fifteenth Century, 168.
} 
mesne process; this was the period between the original writ and the appearance of the defendant before the Court of Common Pleas. As Hastings points out, it seems likely that "the status of the defendant rather than the nature of the action seems to have been the factor which determined the process." 161 The time between delivery of the original writ and the defendant's appearance in court could be as long as two years or as short as six months; this was dependent on where in England the writ was delivered and whether the sheriff in that region fulfilled his duties faithfully. In the case of Londoners suing other Londoners, this time could be much shorter if the defendant was in London at the time; although these cases often ran into the same problem of non-delivery by the sheriff. ${ }^{162}$ For trespass, defendants were usually arrested and paid a fee to stay out of jail until the pleading, if they could afford it. ${ }^{163}$ This arrest and subsequent bail payment could explain the use of attachiatus fuit/attiachiati fuerunt which best translates as "was attached" in the beginnings of these plea records. For example, when Thomas Clayton purchased an original writ against William, son of John Hert, William Quyntyn of Dover, and Peter, the prior of Dover, they "were attached to respond to" his accusation that they had stolen two colts and five bulls, worth sixty shillings. ${ }^{164}$ While these defendants did appear, that the case ends with no real pleading illustrates that they were still not sure how to respond to the charges.

The bulk of the plea rolls for the Court of Common Pleas are taken up by the various writs involved in the mesne process. ${ }^{165}$ Not all defendants appeared before the courts in a timely

\footnotetext{
${ }^{161}$ Hastings, The Court of Common Pleas in the Fifteenth Century, 171. The process refers to whether it would be capias (arrest of the person) or distringas (arrest of the person's good) writ served on the defendant.

${ }^{162}$ Eighteen of the eighty-two cases (21.9 percent) included the phrase "et vicecomes non misit breve, etc," which translates "And the sheriff has not sent the writ, etc." In some cases, like TNA, CP 40/582, rot. 412d., this happens multiple times.

${ }^{163}$ Hastings, The Court of Common Pleas in the Fifteenth Century, 165.

164 In Latin, it reads: "Willelmus filius Johannes Hert Willelmus Quyntyn de Dovorre Et Petrus the Prioresseruant Of Dovorre Attachierunt fuerunt ad respondendum Thome Clayton De placito quare vi et armis duos pullanos et quinque boviculos ipsius Thome praecii sexaginta solidarum apud Sutton iuxta Dovorre inventos ceperunt et abuxerunt et alia enormia ei intulerunt ad grave dampnum ipsius Thome et contra pacem Regis.” TNA, CP 40/579, rot. 316.

165 Hastings, The Court of Common Pleas in the Fifteenth Century, 169.
} 
manner. In those instances, plaintiffs would have to proceed through the long process of outlawing the defendant. This would cost the plaintiff more money and time as they had to wait through five consecutive county court sessions in which the defendant did not appear and then pay another fee for the writ of capias ultagatum. As an outlaw, the defendant forfeited all their possessions to the crown and lost the protection of the law. At that point, the defendant would need to get a reversal of the outlawry. ${ }^{166}$ All of the cases I use in this dissertation bypassed this process, although other delays could still elongate the time before a jury might render a verdict, such as the sheriff failing to impanel a jury or deliver a writ. As soon as the defendant did appear before the court, cases moved onto the next stage of a civil action: pleading.

For this part of the process, both defendant and plaintiff needed to reappear in the Court of Common Pleas in London. Often, they would be represented by an attorney, but not always. While attorneys could help the defendant and plaintiff navigate the intricacies of the writs and appear on their behalf, which would free up either party to continue to work, they did not actively present or argue cases. The first part of the case after the original writ was called the 'count' and represented the plaintiff's reason for going to court. ${ }^{167}$ This was usually more detailed than the information in the original writ, including the precise parish and ward where the trespass occurred, exact date of the tort, weapons used, and a list of the items stolen or damaged in cases of theft and housebreaking, or how long a person was absent in cases of abduction or imprisonment. This needed to be heard first in order for the issue or dispute to be decided. For example, when Robert Colney finally appeared in court to answer Henry Julian and John

\footnotetext{
${ }^{166}$ For more on this process and the process of outlawry, see Hastings, The Court of Common Pleas in the Fifteenth Century, 176-83; Baker, The Oxford History of the Laws of England, Vol. 6; Melissa Sartore, Outlawry, Governance, and Law in Medieval England (New York: Peter Lang Inc., 2013); John C. Appleby, and Paul Dalton, eds. Outlaws in Medieval and Early Modern England: Crime, Government and Society, C. 1066-C. 1600 (Farnham, UK: Ashgate Publishing, 2009).

${ }^{167}$ See Image 2 on page 227 in the appendix for an example of what this looked like on the plea rolls of the Court of Common Pleas.
} 
Bemond, he needed to know the exact accusation against him, in all its detail, in order for him to respond. ${ }^{168}$ In this case, which takes up three full rotulus, has an extensive amount of maneuvering among the litigants over questions of property ownership. However, the personnel of the court, the serjeants at law, were the ones who argued the pleadings, or points of issue, before the court on behalf of the defendant and plaintiff. ${ }^{169}$ These arguments were usually carried out in Law French and the prothonotaries would record these proceedings in their records, also in Law French; these points of issue were subsequently collected in the year books. ${ }^{170}$ The arguments between the serjeants at law were never a part of the official record of the case. Only the final issue and plea were recorded and then translated into Latin for the full record. Once the pleadings were recorded, no changes could be made. ${ }^{171}$

There were three options for the defendant upon appearing before the court: (1) they could admit to the wrong, (2) ask for a continuance, otherwise known as a license to imparl (which was most common on the first appearance), or (3) enter a plea. When entering a plea, there were four options from which a defendant had to choose. ${ }^{172}$ The first option, and the most common and easiest plea, was pleading "not guilty", which meant a general denial of everything laid out in the original writ and count; this was called pleading a general issue. Fancoby, from the case at the beginning of the chapter, chose this first option. A second option was pleading a special issue. With this plea, the defendant could deny a particular fact from the plaintiff' s count.

\footnotetext{
168 This case appears on two earlier rolls before finally getting a full pleading from Bemond. However, in those instances, Bemond failed to show in court, which resulted in the sheriff adding taking more money or goods in order to force his appearance. TNA, CP 40/598, rots. 104-105(d); TNA, CP 40/597, rot. 210; TNA, CP 40/596, rot. 179. ${ }^{169}$ Hastings, The Court of Common Pleas in the Fifteenth Century, 59.

${ }^{170}$ Year books were essentially notes from either observers in the courts or the prothonotaries themselves. The idea was not to have a continuous recording of the session, but rather something that could be studied and learned from in terms of points of law. These year books would circulate through the various Inns of Court and be copied by anyone so inclined to use for their own study. Baker, The Oxford History of the Laws of England, Vol. 6, 473-89.

${ }^{171}$ Baker, An Introduction to English Legal History, 93.

172 Hastings, The Court of Common Pleas in the Fifteenth Century, 184.
} 
As a third option, the defendant could admit to the general facts of the case but deny the plaintiff's right to sue; this was known as a demurrer. Finally, with the fourth option, defendants could admit to the facts of the case, but offer further information about the circumstances which might justify their (the defendant's) actions. In other words, the defendant provides a reason that their actions were licit, or acceptable, rather than wrong; Baker identifies this as "confession and avoidance." ${ }^{173}$ However, defendants could only plead one point, or one special issue. This means that in "confession and avoidance" pleadings litigants still had to come to a point that the jury would be able to make a ruling on. The arguments occurring in the court in Law French debated which special issue to raise. The pleadings decided what point of law the jury would be considering at trial: was the jury going to decide innocence, or right to sue, or a particular point of contention raised in pleading? ${ }^{174}$ In the case of Julian $v$. Colney, for example, the point of issue the jury needed to render a verdict on was who had the right to lease out a building in London. The building in question was the site of the alleged violent act, a temporary eviction and theft of ten pounds worth of goods. ${ }^{175}$ At this stage, many suits would be settled out of court. ${ }^{176}$ If the parties did not come to an out-of-court agreement and a plea was entered, the case was sent to the local assize courts for a trial, usually a jury trial, which was the fourth and final stage of a civil suit.

This trial, if one occurred, usually took place where the violent act happened. When John Moubray accused William Tendre of theft in the parish of St. Michael in Cornhill Ward, the order went to one of the London sheriffs to impanel a jury. ${ }^{177}$ However, if there was another

\footnotetext{
173 Baker, An Introduction to English Legal History, 91-92.

174 Baker, An Introduction to English Legal History, 92-94.

175 TNA, CP 40/598, rots. 104-105(d).

176 Plaintiffs often took a defendant to court in order to force them into arbitration. This arbitration usually occurred after the initial pleading stage of a case. I discuss this in more detail in chapter three.

${ }^{177}$ In Latin, this reads: "Ideo preceptum est vicecomiti quod venire faciant hic in octave sancte Hillari xii etc., per quos etc., et qui nec etc., ad recognoscendum etc., quia tam etc." TNA, CP 40/587, rot. 220.
} 
event or point of issue in question, the trial would occur in that locality. For instance, when John Hankyn claimed that he and Richard Lorkyn (the plaintiff) had entered into an arbitration agreement over the events in question somewhere in the parish of St. Dunstan in the East in Tower Ward, the jury was impaneled there instead of in Rochester in Kent, where the alleged wrong happened. ${ }^{178}$ The local sheriff summoned a jury of twelve men and the facts were presented. ${ }^{179}$ Based on the outcome of the pleading, the jury would decide on the guilt or innocence of the defendant, right of the plaintiff to sue, or whether the point of contention in the writ was true or false. Unfortunately, there were no court recorders in the Middle Ages. Judges sometimes took notes for themselves, but these would not be used in court. Juries were strictly forbidden from deciding on facts outside of the plea entered at the Court of Common Pleas. The outcome of that trial was then sent back to the Court of Common Pleas to be entered into the plea rolls. ${ }^{180}$ For the latter two, deciding on the point of contention or the right of the plaintiff to sue, two different outcomes could happen. If the jury decided the plaintiff did not have the right to sue or that the point of contention was true, the case would be over. If they decided the plaintiff did have the right to sue or that the point of contention was false, it would go back to the Court of Common Pleas and the next pleading would occur there. Pleadings took on an importance that often superseded the facts of the case; Baker explains that "whereas the twelfth-century Dialogue of the Exchequer had referred to litigation as a game of hazard, it had become a game of skill, played out by the masters of pleading at the bar of the Common Pleas." ${ }^{181}$ The cycle of pleadings

\footnotetext{
178 TNA, CP 40/616, rot. 313d.

179 Juries in civil suits could ask questions and were often considered more in the vein of fact-finding instruments. And while not all civil cases had to be held in front of a jury, it was the most common form of trial. It is unclear what court in London might have heard these cases as Hastings only names the court as the assizes of that particular county. However, from evidence listed in the court records themselves, this seems to be (for London) the assize at St. Martin le Grand. Hastings, The Court of Common Pleas in the Fifteenth Century, 202. See, for example, TNA, CP 40/568, rot. 289d.

${ }^{180}$ Hastings, The Court of Common Pleas in the Fifteenth Century, 204-05.

${ }^{181}$ Baker, An Introduction to English Legal History, 91.
} 
would continue until there was a resolution to the case (in or out of court), the plaintiff dropped the case, or either the defendant or plaintiff, or both, died. The records that I am using contain the summaries of all of these processes, including the outcome of the trial if it went that far and any damages awarded.

Not every action allowed a plaintiff to request damages, but the trespass actions did. ${ }^{182}$ The concept of damages was one of restitution for the wrong done to the plaintiff. For example, being the victim of a violent assault might not have resulted in the loss of goods valued at a certain amount, but it was still argued the plaintiff lost something as a result of the trespass. Furthermore, the amount requested in damages may have had just as much to do with the reputations of the litigants as with the actual wrong under consideration. ${ }^{183}$ Plaintiffs rarely included a rationale behind why they requested that amount in damages. In addition, requesting damages was a way to recoup some of the court costs, to recover the cost of suing for the wrong in the first place. What might seem like inflation of the cost of violence might be an overestimation by the plaintiff as to how much it was going to cost them to sue the defendant; unlike many modern legal systems, there was no process to add in court costs after the verdict was rendered. ${ }^{184}$ Despite the high amounts often requested in damages, the highest among my cases was 1,000 marks (or 666 pounds, thirteen shillings, and four pence), most plaintiffs received only a fraction of that. ${ }^{185}$ Since the majority of cases enrolled on the rolls of the Court of Common Pleas do not have a conclusion, it is difficult to accurately assess what percentage of damages was awarded, on average, compared with what was requested. Still, one can ascertain

\footnotetext{
${ }^{182}$ Most cases of debt were not eligible for damages, for example. See Tucker, Law Courts and Lawyers in London, 201-07.

183 Phipps, "Misbehaving Women," 65. Although, she also asserts that recovering one's reputation was a factor in both the decision to sue and in how much to request in damages.

${ }^{184}$ Baker, The Oxford History of the Laws of England, Vol. 6, 375.

185 TNA, CP 40/601, rot. 139. The lowest request in damages was for ten marks (or six pounds, thirteen shillings, and four pence): TNA, CP 40/615, rot. 445; TNA, CP 40/600, rot. 449.
} 
that suing in the Court of Common Pleas was a costly venture. ${ }^{186}$

\section{Conclusion}

The low percentage of completion rates for cases before the Court of Common Pleas raises the question of why plaintiffs brought their actions in this court, or any court at all. The sheer number of cases enrolled on a single term's roll illustrates this litigiousness. An average of 6,000 entries a term, means around 24,000 entries a year. Even if we only take the entries whose processes made it beyond the mesne stage of a suit, it would still be around 4,000 cases a year, in one of the most expensive courts in England. This commitment to pursuing a suit, sometimes over years, and at great cost to the plaintiff, suggests that the issues at stake were of great importance to the litigants: that the violence and injury allegedly done to them was worth the time taken and price tag attached and was worth the hassle associated with navigating the legal systems of England.

This price tag, however, meant that the poor of London would not have had their cases heard by a highly trained legal expert. As most sheriffs and mayors only served one-year terms, the support staff for their courts and official duties became even more important in ensuring effective government. The demands placed on the city courts by the people of London encouraged a professionalization of the clerks; this was a slow process, taking over a century to complete. For Londoners, their local courts would have been the easiest and least expensive to access. The same would be true for local courts around the country. Suing, or even appealing as a crime, was less complex at the local level, especially if done by bill or oral complaint. There

\footnotetext{
${ }^{186}$ Of the four cases in which a plaintiff won damages (out of eighty-two), they only received an average of 15.9 percent of what they requested. William Westwode was awarded thirteen pounds out of the 100 pounds he requested TNA, CP 40/579, rot. 160; Thomas de Lye and William Clerk were awarded fourteen out of the twenty pounds requested TNA, CP 40/611, rot. 597; John Gerland only received one shilling, one pence out of the 100 marks (sixty-six pounds, thirteen shillings, four pence) requested TNA, CP 40/617, rot. 179; and Thomas Elyngham received six out of the ten pounds he requested TNA, CP 40/619, rot. 520.
} 
were no complex writs and legal formula that a litigant's story had to abide by, nor did one have to pay an attorney or serjeant at law to plead their case. People did employ attorneys and pleaders in the local courts, but that was by choice rather than by requirement. While records may have been maintained in Latin, most of the courts' business would have been done in English, so litigants understood what was being said to them and about them. ${ }^{187}$ In addition, based on exposure to the courts on a regular basis, most litigants would have been familiar with the proceedings. Bills were less expensive than writs and an oral complaint cost nothing. Choosing to pursue a case in either the Sheriffs' Courts or the Mayor's Court might have been attractive to litigants because it was a less formal system.

The relative ease with which a litigant might access a London court could have been a benefit for some, but others might have viewed it as problematic. Londoners might have chosen to pursue their cases in the Court of Common Pleas because of the more informal nature of the city courts. By the beginning of the fifteenth century, the rules and procedures for the central courts were well established. In addition, there was a semi-professionalized staff by way of clerks and serjeants at law for the Court of Common Pleas; this professionalization was less developed at the beginning of the 1400s in London courts than in the central courts. That certain courts, such as the Mayor's and Sheriffs' held sessions on any given day of the week to accommodate for travel for non-Londoners, seems to illustrate the lack of power the courts had in forcing the appearance of foreigners (whether that meant foreign to just London or to England in general). This was not an issue for the central courts, as far as the king's subjects were concerned. With the support of the king, writs could be sent to the far corners of his domain. Of

\footnotetext{
${ }^{187}$ Here I am referring to London courts, such as the Sheriffs' Courts, accessible to any Londoner regardless of economic standing. Clanchy, From Memory to Written Record, 339; Tucker, Law Courts and Lawyers in London, $336,366$.
} 
course, that did not mean getting a defendant to appear in court was any easier, but the power to compel attendance was there. This royal backing, as well as long history, may have made the central courts appealing to people from all over England seeking justice.

However, those who experienced an assault or a violent theft could have also chosen the Court of the King's Bench to pursue their cases. As the court of first instance for Middlesex, it could hear criminal cases by bill, which would make it less expensive than purchasing a writ. Litigants avoided having to pay a serjeant at law to plead their cases in this court as well. The Court of the King's Bench had royal power backing its verdicts and it was considered the superior court over the Court of Common Pleas. The court could also, if granted the writ by Chancery, entertain trespass vi et armis actions. While the plaintiff still had to pay the cost of the original writ, they did not have the same court costs as those associated with the Court of Common Pleas. In some instances, this court would also try the civil suit rather than send it to a local court for trial, saving litigants some travel expenses.

As the court which not only helped shape civil litigation, but also trained generations of lawyers, the Court of Common Pleas had much to offer the victim of a wrong. The procedures for the court were well established; its cases were studied at the Inns. The serjeants at law who pleaded the cases were highly trained with years of experience in the law. The clerks who worked for the courts were also highly trained professionals, skilled in the law, with knowledge of legal languages, and the various writs. The records were kept well organized and easily accessible to the officers of the court. ${ }^{188}$ Trials would be held in the locations where the violent tort occurred, which meant a local jury who might be aware of the incident in question. These advantages, and the associated cost, suggest a level of seriousness in litigation that might be

\footnotetext{
188 They were kept well organized during the fifteenth century, although accessing all the records now can be difficult, something I discuss in chapter three.
} 
absent in other courts.

It was this gravitas that pulled litigants towards this court. The Chancellor did decide which of the two courts, Court of the King's Bench or Court of Common Pleas, would entertain a trespass action, but he favored the Court of Common Pleas for these cases. Plaintiffs who wanted royal backing of the decisions in the case, even when decided by local juries, would choose a central court over a local court. The Court of Common Pleas was an expensive court to use and perhaps because of this the delays seen in the Sheriffs' Courts in London did not happen in the Court of Common Pleas, despite its heavy caseload. The majority of mesne process took place outside of the court, which left the serjeants at law and justices to debate the finer points of pleading when in session. In addition, the Court of Common Pleas had the power to compel the attendance of litigants from all over England, a power that was not present at the local level.

However, plaintiffs did not necessarily need to choose only one of these courts to pursue their agenda. For some plaintiffs, it could be a successive escalation. They might have taken the defendant to one of the sheriff's courts first, but found either a biased jury, or decided the progression of the case was too slow. Perhaps being brought before the sheriff's court did not compel the defendant into arbitration, as the plaintiff had hoped. At that point, the plaintiff might have decided to increase the inconvenience and cost to the defendant by going to one of the central courts. Some plaintiffs, though, could afford the cost of multiple suits in multiple courts all at once. They might have initiated suits for the same event under both criminal and civil procedures, in multiple levels of court. In this way they might be trying to see which court was going to give them the outcome which they desired. Or perhaps having all these actions at once sufficiently harassed the defendant into either settling or giving up. Although it is not just the plaintiffs who might be forum shopping, a defendant might fail to appear in a local court because 
they wanted the plaintiff to move the case into a central court; the defendant might have known that differences in procedures might benefit their defense.

A litigant needed to weigh the advantages and disadvantages of each court and then make a careful decision based on their ability to pay, the type of wrong, as well as their desired results. However they chose a court, the Court of Common Pleas had a lot to offer a plaintiff with some money to spare and a desire to receive restitution for a wrong. It could also be beneficial to defendants seeking the advantages of civil procedure at the central court level. Its highly trained personnel, the backing of royal power, and the ability to make non-Londoners appear all served as enticements for a litigious Londoner when faced with the decision to use a local court over a central court. 


\section{Chapter 3 - Savvy Litigators: Creating Order from Chaos}

\section{Introduction}

Relatively soon after her husband's death, Alice Wiltshire appeared before the Court of Common Pleas to answer John Neyr during Trinity law term of 1406 . Her husband was alive as of February 2, 1405 when the alleged theft happened, but was deceased by mid-June 1406, when the case came to the Court of Common Pleas. ${ }^{1}$ According to Neyr's count, Wiltshire, along with Robert Berle, allegedly stole ten pounds worth of goods, including four books and a silver jar. ${ }^{2}$ In their defense, Wiltshire and Berle not only took exception to the value of the goods as claimed by Neyr, but they also pleaded a "confession and avoidance", namely that the goods belonged to Wiltshire's late husband, John Wiltshire, and they had been used by him as collateral in a loan. ${ }^{3}$ Wiltshire and Berle further explained that the three litigants had gone together to pay off said loan and to retrieve the goods. As they finished their pleading, the defendants reiterated that while Neyr might have been temporarily in possession of the goods, it was only to bring them back to the Wiltshires, which he failed to do. In his rejoinder, Neyr denied their claims and so the case would have gone before a jury, unless the parties came to an agreement outside of court.

As the previous chapters showed, it was rare for a case to reach a conclusion within the records of the Court of Common Pleas and Neyr v. Berle was no exception. Most cases enrolled in the plea rolls of the Court of Common Pleas were in the mesne process, somewhere between

\footnotetext{
${ }^{1}$ There is no indication in the records as to when during that seventeen-month time span he died. The National Archives, CP 40/582, rot. 219; hereafter, TNA.

2 In Latin, the count reads: "Johannes Neyr in propria persona sua queritur quod Ricardus et Alicia in festo puri beate Marie anno regni domini regis nunc sexto vi et armis scilicet gladiis arcubus et sagittis bona et catalla videlicet unam ollam argenti - unum librum vocatum pratum florum unum librum de fisito unum librum de statutus unum librum vocatum natura brevium rotulos et memorandum curia ipsius Johannis Neyr ad valenciam etc apud London in parochia beate Marie de Aldirmanbury in Warda de Cripelgate inventa ceperunt et asportaverunt et alia enormia." ${ }^{3}$ As discussed in detail in chapter two, there were four types of pleadings open to a defendant: 1) not guilty, 2) special issue, 3) demurrer, 4) confession and avoidance.
} 
the original writ and the pleading stage. ${ }^{4}$ The data one can ascertain from those cases is more limited, although not necessarily less useful, than that of the data one gets from a case in the advanced stages: those at the pleading level or beyond. Many of the cases I use throughout this dissertation can still be sparse in details even though they reached the pleading stage. Defendants often came to court and pleaded "not guilty," which was known as a general issue, offering no further information about the claims of the plaintiff; ${ }^{5}$ in those cases, there is also no further information from the plaintiffs themselves. However, there are cases in which the defendants pleaded something other than "not guilty" and it is to some of those cases I now turn. Within these cases where defendants entered a special pleading, litigants provided more information about themselves, the details of the alleged event, and societal values, albeit through the formulaic language of the courts. ${ }^{6}$

In terms of the records of the Court of Common Pleas, the documents were "instruments of the historical process"7 rather than records that faithfully reflect events that transpired. However, they do illustrate savvy litigators and how they manipulated the courts to achieve their end goals. As with other records, and legal documents especially, what someone recorded had a particular purpose; there was a reason these litigants were in court and while they had a hand in

\footnotetext{
${ }^{4}$ While in the book, The Death of the American Trial, Robert P. Burns laments said death, most cases considered in this dissertation did not make it to trial either. As he cites in his introduction, civil trials have declined to 1.8 percent over a forty-year period in the modern United States, yet in the ten-year time span covered by this dissertation, only nine percent of cases concluded, with six percent having concluded via a trial. The motivations for going to court may have changed in the interceding 600 years between my litigants and those discussed in Burns' book, but some of the hardships still remain. Going to court continues to cost time and money and litigants still have to navigate a labyrinthine legal system. The Death of the American Trial (Chicago: University of Chicago Press, 2009), 2.

${ }^{5}$ The language to describe these pleadings, which were described in more detail in chapter two, was taken from J.H. Baker, An Introduction to English Legal History (Oxford: Oxford University Press, 2007), 91-92.

${ }^{6}$ What I am calling a special pleading is any of the three types of pleading other than "not guilty" as discussed in chapter two.

${ }^{7}$ Shannon McSheffrey, private communication. See Shannon McSheffrey, "Detective Fiction in the Archives: Court Records and the Uses of Law in Late Medieval England," History Workshop Journal 65, no. 1 (2008); Shannon McSheffrey, "The Slaying of Sir William Pennington: Legal Narrative and the Late Medieval English Archive," Florilegium 28 (2011) for more on processes of and influences on creating a legal record.
} 
what was ultimately recorded for the Court of Common Pleas rolls, other voices contributed too. ${ }^{8}$

Nevertheless, all participants had the same end goal: to craft a narrative that would win the case.

For plaintiffs, this meant a believable story of illicit violence as the first step towards whatever

their ultimate goal might have been, whether that was forcing arbitration, preserving reputation, gaining damages for a loss, or perhaps settling an entirely different dispute. For the defendants, this might have meant establishing ownership of property, such as in the Neyr $v$. Berle case which opened the chapter, showing the issue was settled through prior arbitration, or arguing that it was not a question for the courts to decide.

Despite their limitations, one should consider carefully these cases in all of their complexity for what they might reveal about the art of crafting a fictionalized narrative that advanced the cause of the litigants. ${ }^{9}$ It is not enough to take the cases at face value; instead we should question the processes behind making them and, in turn, archiving them. How did they come to be? Who had the opportunity to speak in these records? Who was silenced? These cases do not represent the truth of the events in question, but rather someone's (or several people's) version of the events. Truth is an interesting word, one which we might be forgiven for assuming has always been synonymous with fact. Richard Green shows that this was decidedly not the

\footnotetext{
${ }^{8}$ While the Court of Common Pleas does have prothonotaries, these are not the same as the notaries discussed by both Kathryn Burns and M.T. Clanchy. Notaries worked for a particular client, while the prothonotaries of the Court of Common Pleas worked for the court itself. However, their respective conclusions are still applicable to these cases. Burns examined notaries in Spanish Colonial America and as she argues, what made it into a notarial record was done by a process of negotiation between the notary and their client; the Court of Common Pleas saw the same issues of who had access to the services, the use of formulaic language, as well as the negotiations between the recorder and litigants. See Kathryn Burns, "Notaries, Truth, and Consequences," American Historical Review 110, no. 2 (2005), 355. M.T. Clanchy's claim that "the fact that a document is signed by a notary does not mean that the statements in it are true in themselves, but that they are true in law" is equally valid for cases enrolled in the Court of Common Pleas and is of particular use for this chapter. Michael T. Clanchy, From Memory to Written Record: England 1066-1307 (Chichester: Wiley-Blackwell, 2013), 435. In addition, most of the cases before the Court of Common Pleas do not come to a conclusion, which means neither side was ever certified as the legal truth by a verdict.

${ }^{9}$ Here, I am using the idea of fictionalization as described by Natalie Zemon Davis, Fiction in the Archives: Pardon Tales and Their Tellers in Sixteenth-Century France (Stanford, CA: Stanford University Press, 1987).
} 
case in his book, A Crisis in Truth, in part of which he traces how the Middle English word 'trouthe' went from meaning integrity of a person to a verifiable fact. ${ }^{10}$ This shift in meaning occurred over centuries, beginning in the late thirteenth century and culminating in our modern conceptions of truth, especially of legal truth. ${ }^{11}$ By the fifteenth century, the shift was already underway, as Green explains, as a result of increased literacy, although the emphasis on written documents to support a claim was slower to occur in England than on the continent. ${ }^{12}$ Even on the continent, debates continued around the different conceptualizations of truth. Corinne Leveleux-Teixeira explains this in her article, "Droit et Vérité" where she concludes that "la vérité, comme la fiction, la présomption ou l'opinion, devient sinon une technique juridique à part entière, du moins un instrument au service du droit." ${ }^{13}$ In short, the truth was subjective.

The idea that the information presented in the records of the Court of Common Pleas was not an unbiased account of the litigants' oral testimony, or in some cases a faithful representation of the events in question, presents a twofold challenge: the first is a challenge of knowledge. What is of use to a historian who searches through documented evidence when "what is documentable is sometimes false, and indeed deliberately written so as to deceive"? ${ }^{14}$ Second, how does knowing a document may or may not represent factual truth help us assess and use what it contains? As Carlo Ginzburg notes in his work with inquisitorial records, "the voices of the accused reach us strangled, altered, distorted; in many cases, they haven't reached us at

\footnotetext{
${ }^{10}$ Richard Firth Green, A Crisis of Truth: Literature and Law in Ricardian England (Philadelphia: University of Pennsylvania Press, 1999), xiv.

${ }^{11}$ Green, A Crisis of Truth: Literature and Law in Ricardian England, xv.

${ }^{12}$ Green, A Crisis of Truth: Literature and Law in Ricardian England, xiv, 378.

13 "The truth, like fiction, presumption or opinion, otherwise becomes a legal technique its own right, at least an instrument in service of the law." Corinne Leveleux-Teixeira, "Droit et vérité: le point de vue de la doctrine médiévale (XIIe-XVe siècles) ou la vérité entre opinion et fiction,” Bien Dire et Bien Aprandre 23 (2005), 349.

${ }^{14}$ McSheffrey, "Detective Fiction in the Archives," 73; Kathryn Burns points out a similar issue of possible falsification in her work on Peruvian notaries Burns, "Notaries, Truth, and Consequences"; Kathryn Burns, Into the Archive: Writing and Power in Colonial Peru (Durham, NC: Duke University Press, 2010).
} 
all."15 The views of the alleged witches' in Ginzburg's history are distorted by the people recording their responses; however, when one examines the gaps between the questions asked and the responses given, Ginzburg argues one can get a glimpse into the beliefs of the accused rather than the recorder. ${ }^{16}$ Some historians though, like Osvaldo Raggio, want to find more than the voices of the common person in judicial records. In his book on state formation in Genoa, he uses judicial records precisely because they can illustrate the complex negotiations that occurred between society and government. ${ }^{17}$ It is the bias itself, the conflicting voices that both Ginzburg and Raggio use within the sources, albeit for different aims, that can be of value in judicial records.

Even when a historian chooses a set of legal records for how the combined voices illustrate the process of negotiation, they must be careful not to be too dismissive of any formulaic language found within those records. It is because of the problematic nature of formulaic language that cases in which the defendants pleaded a special issue offer the most information in terms of understanding the motives and machinations of litigants before the Court of Common Pleas; the added information from both plaintiff and defendant in cases with special issue pleas provide what Ginzburg called the gap between official and litigant voices, although dismissing the violent nature of the alleged event can be a problem when using trespass vi et armis cases, as discussed previously. ${ }^{18}$ In general, the concept behind a legal fiction (whether $v i$

\footnotetext{
${ }^{15}$ Carlo Ginzburg, Ecstasies: Deciphering the Witches' Sabbath, trans. Raymond Rosenthal (New York: Penguin Books, 1991), 10.

${ }^{16}$ Carlo Ginzburg, The Night Battles: Witchcraft and Agrarian Cults in the Sixteenth and Seventeenth Centuries, v, trans. Anne Tedeschi, and John Tedeschi (Baltimore, MD: John Hopkins University Press, 1992), xiv, xviii. See also, Carlo Ginzburg, The Cheese and the Worms: The Cosmos of a Sixteenth-Century Miller, v, trans. Anne Tedeschi, and John Tedeschi (Baltimore, MD: John Hopkins University Press, 1982), xv, xix.

${ }^{17}$ Osvaldo Raggio, Feuds and State Formation, 1550-1700, trans. Matthew A. Vester (New York: Palgrave Macmillan, 2018), 16.

${ }^{18}$ Ginzburg, The Night Battles: Witchcraft and Agrarian Cults in the Sixteenth and Seventeenth Centuries, xviii. I examine the issues around legal fictions in more detail in chapter one.
} 
et armis or some other, like the Bill of Middlesex) was that no one in the court believed the allegations; they all knew the charges were falsified in order to bring a certain action before a particular court. ${ }^{19}$ Taking this stance, one might assume no violence occurred in any of these cases because the plaintiff made up the allegations in total.

In this dissertation, while acknowledging that some of the cases might be legal fictions, I use them for what they might illustrate not only about concepts of violence, but also the machinations and stratagems employed by litigants. Donald Sutherland talks about an interesting set of legal fictions used by both plaintiffs and defendants, although not in vi et armis actions, in his article "Legal Reasoning in the Fourteenth Century." In these cases, the plaintiff began an assize of novel disseisin in which they claimed to have been violently ejected from their property, although what property that was did not have to be explained. ${ }^{20}$ The fiction, in this case, was probably the violence, which the plaintiff falsified in order to get a case heard more expeditiously. ${ }^{21}$ The defendant in their pleading to the allegations "gives color" to the plaintiff by explaining not only their claims to the property in question, but also the plaintiff's. Introducing the competing claims to the property sets up the introduction of proof during either the settlement or trial of the case as to the ownership of said property. This is where the second legal fiction comes into the case; often, "what the defendant said about the plaintiff"s claim was not

\footnotetext{
${ }^{19}$ Another example of a legal fiction, one discussed in detail by Joseph Biancalana, was that of common recovery. To simplify a complex process, plaintiffs, defendants, and a common vouchee set out to manipulate the courts in order to transfer ownership of entailed property. A common voucher was a person who sat in the courtroom and, for a fee, would pledge to stand in the plaintiffs' stead as the case continued. The advantage of this, according to Biancalana, was that "the feigned litigation of common recovery prevented real litigation later." The Fee Tail and the Common Recovery in Medieval England (Cambridge: Cambridge University Press, 2001), 251-253, 259. ${ }^{20}$ Donald W. Sutherland, "Legal Reasoning in the Fourteenth Century: The Invention of 'Color' in Pleading," in On the Laws and Customs of England: Essays in Honor of Samuel E. Thorne, ed. Samuel E. Thorne, and Morris S. Arnold (Chapel Hill: University of North Carolina Press, 1981), 183. As George Woodbine explains in his two-part article, "Origins of the Action of Trespass," the assize of novel disseisin was what gave rise to the action of trespass vi et armis. George E Woodbine, "Origins of the Action of Trespass," Yale Law Journal 33, no. 8 (1924); George E Woodbine, "Origins of the Action of Trespass," Yale Law Journal 34, no. 4 (1925).

${ }^{21}$ This conclusion is similar to those put forward by Philippa Maddern, Richard Kaeuper, Warren Brown, Janet Loengard, and M.W. McHaffie concerning trespass vi et armis as discussed in chapter one.
} 
true and not expected to be true, but pure sham, pure fiction." 22 Some of the narratives in these pleaded cases could have false information, given in order to advance their case, although there is a fine line between a legal fiction and a fictionalized narrative.

The creation of a legal narrative is bound to have some fictionalization, whether purposeful or a product of memory retrieval, however, that does not mean the narrative should be dismissed. Coroners' rolls were especially prone to memory problems, which Carrie Smith discusses in her article about whether historians should consider these rolls fact or fiction. Problems include production of the rolls months or years after the death occurred, underreporting of death by villagers or townspeople, lack of details in the records themselves, and questionable dates listed in the records. ${ }^{23}$ Despite the many issues with using coroners' rolls, Smith argues that legal records still provide a way to gain insight into the lives of the people below noble status. ${ }^{24}$ Perhaps instead, as Tom Johnson does in his article on the construction of witness testimony, a historian can read depositions and testimonies as one might literature, perhaps a fiction, but one that needed to be believable to the people who would read or hear it. Johnson was specifically looking at the depositions surrounding a series of events that occurred in Twickenham on East in 1524; in these depositions he not only acknowledges the voices of the lawyers that influenced what made it into the records, but also that witnesses might "preconstruct" their testimony, thus inserting their own interpretation of events that was at odds with the narrative that the lawyers for each side attempted to create with their leading questions. ${ }^{25}$ Noël James Menuge and Joel Rosenthal, similarly, examine what these constructed narratives might show a historian using

\footnotetext{
${ }^{22}$ Sutherland, "Legal Reasoning in the Fourteenth Century: The Invention of 'Color' in Pleading," 184.

${ }^{23}$ Carrie Smith, "Medieval Coroners' Rolls: Legal Fiction or Historical Fact?," in Courts, Counties and the Capital in the Later Middle Ages, ed. Diana E. S. Dunn (New York: St. Martin's Press, 1996), 96-104.

${ }^{24}$ Smith, "Medieval Coroners' Rolls: Legal Fiction or Historical Fact?”, 93.

25 Tom Johnson, "The Preconstruction of Witness Testimony: Law and Social Discourse in England before the Reformation," Law and History Review 32, no. 1 (2014), 144.
} 
legal records. In any kind of court, people were on opposing sides, as Rosenthal explains, and thus catered their depositions or testimony to bolster the side they identified with. ${ }^{26}$ Menuge argues that not only can a historian "examine the legal case for what it can tell [them] about legal practice but also for what it can tell [them] about the strategies" of litigants. ${ }^{27}$ It is this last point on the savviness of litigants in crafting narratives which I endeavor to show in this dissertation, but especially in this chapter.

These narratives, the ones recorded in the combined language of the clerks and litigants, have legal weight in the sense that these were the official stories put forward by the litigants. Once a set of facts had been entered on the official plea roll, a litigant could not revise their narrative. If a point of fact was incorrect, either the defendant was acquitted, or the plaintiff had to start the suit again with the correct facts. However, these narratives also have historical weight in that they have been preserved on parchment for posterity as possibly the only surviving record of these people and their versions of the dispute; more importantly, they reveal what strategies were employed to achieve the ends of the parties involved in the case. Since only three of the cases I use in this chapter come to a conclusion, there is little evidence to illustrate whose narrative a jury would have decided was the closest to the truth; it would only be after this stage that one of the narratives would have passed into being fully the legal truth. ${ }^{28}$ Part of the reason for this lack of closure was that many litigants settled out of court, usually through arbitration which resulted in neither side's narrative 'winning' as it were. Unfortunately, for the cases in this

\footnotetext{
${ }^{26}$ Joel Thomas Rosenthal, Telling Tales: Sources and Narration in Late Medieval England (University Park, PA: Pennsylvania State University Press, 2003), 149-50. Although witnesses did not always provide testimony that supported the side which summoned them to court.

${ }^{27}$ Noël James Menuge, "Reading Constructed Narratives: An Orphaned Medieval Heiress and the Legal Case as Literature," in Medieval Women: Texts and Contexts in Late Medieval Britain, ed. Jocelyn Wogan-Browne (Turnhoult: Brepols, 2000), 116.

${ }^{28}$ Of the cases that concluded, two plaintiffs won their case, while one plaintiff defaulted so the case was decided in favor of the defendant.
} 
dissertation, I do not have the outcomes of arbitration, if indeed they concluded in that way. At the point in the case in which I examine them, they are competing versions of that truth.

I analyze forty-four cases in this chapter in an effort to understand how narratives were created and pursued to help the plaintiffs' and defendants' causes in the Court of Common Pleas. The cases run the gamut of torts, including assault, abduction, imprisonment, housebreaking, and theft. ${ }^{29}$ They also span the full spectrum of the years covered by my dissertation: 1405 to 1415 . I chose many of these cases because during the pleading stage at least one of the defendants pleaded a special issue or used a demurrer. This means that not only do we have the original writ, as well as the count (the more detailed story from the plaintiff) and the plea (the story as told by the defendant), but quite frequently the rejoinder as well (the response to the defendant's plea by the plaintiff). While this was all still filtered through the prothonotaries and clerks of the court, and still were recorded in formulaic language, the plea and rejoinder each give more details of the events than the count alone. By focusing on cases that included narratives from both the plaintiffs and the defendants, I can examine the different ways in which litigants negotiated, through legal stratagems, different concepts of order and disorder, of licit and illicit violence. Having knowledge of the legal systems available to them, both plaintiffs and defendants used the courts to achieve their end goals. For many plaintiffs, initiating a civil action might simply be a part of the arbitration process, or a way to gain recompense for an economic loss, or perhaps to bring a defendant to court for another dispute altogether. These machinations, however, could also be used by defendants; whether that was attempting to enforce a prior arbitration or

\footnotetext{
29 The only tort missing from this list (and the cases discussed in the subsequent chapters) out of all torts under the action of trespass vi et armis is disseisin. The formula for these cases meant that the plaintiff had to assert that some form of violence occurred during the commission of the wrong, or tort. Housebreaking, or our modern burglary or breaking and entering, was often accompanied by the theft of goods and was never the sole tort for any of the cases between 1405 and 1415. See Table 8 on page 228 for a breakdown of cases by tort.
} 
establishing legal ownership of property.

More often than not, these cases came down to a battle of narratives, of "he said, he said" situations. In the first section of the chapter, I examine various motives that might have prompted plaintiffs to bring their case to court and specifically to the Court of Common Pleas. The local juries, taken from the wards around where the tort occurred, might know some of the story and might know the plaintiff or defendant. ${ }^{30}$ But, they might not. In a typical late medieval trial in England, plaintiffs would be able to call witnesses, while defendants often could not or if they did, the witnesses were not considered as credible as the plaintiff's witnesses. ${ }^{31}$ Therefore, in the second section, I analyze possible defendant motives, as well as strategies employed, in order to maximize their chances of achieving their end goals. A lack of documentation, and therefore a reliance on witness testimony, might have presented a problem for the third set of cases, ones in which the defendants reported prior arbitration. For the ten cases in this section, the defendants crafted a narrative that denied the plaintiffs' right to sue based on a previous arbitration between the litigants. Finally, in the last section are the cases in which litigants' narratives suggest concerns with both monetary compensation and reputations. In the thirteen cases, none of the defendants denied that the particular wrong occurred, they simply claimed that the plaintiff did not have the right to sue them for it. These defendants, with the help of the court officials and their attorneys (when they had them), crafted a defense narrative that not only redrafted the disorder of the wrong into a story of order, but also increased their chances of being believed by a jury of their peers.

\section{Exploration of Plaintiff's Motives}

\footnotetext{
${ }^{30}$ Penny Tucker, Law Courts and Lawyers in the City of London 1300-1550 (Cambridge Studies in English Legal History) (Cambridge: Cambridge University Press, 2007), 224-26.

${ }^{31}$ Baker, An Introduction to English Legal History, 581-82.
} 
In order to get to the narrative as seen in the records there was a lengthy process that a case before the Court of Common Pleas went through to become a historical instrument. First, there was the plaintiff, the person, or persons, who initiated the suit in the first place. They had a problem, real or invented, with the defendant(s) named in the case. The plaintiff's case was either real or invented because while they clearly had a problem with the other party, it may not have been what the suit was about. ${ }^{32}$ To complicate matters further, the plaintiff told their story to a different court to begin the proceedings; this was then filtered through at least one court clerk to become the original writ. Unfortunately for historians of the Court of Common Pleas, most of these original writs are currently housed in the salt mines, a cold storage facility for The National Archives, and are inaccessible to researchers. ${ }^{33}$ The plaintiff then had to tell the story again to the justices of the Court of Common Pleas. There could have been a certain amount of embellishment in these accounts, over-exaggerating the damage done, or fear felt. Most likely this accounting of the events would have been done in English with the members of the court speaking and questioning in either Law French or English. Clerks then boiled down the plaintiffs' narratives to mostly formulaic phrases and recorded them in Latin; as one can see, translations (both literal and figurative) abounded. ${ }^{34}$

In a way, the act of suing was an avenue for plaintiffs to restore order to their lives by

\footnotetext{
${ }^{32}$ See the discussion of legal fiction in chapter one.

${ }^{33}$ These were once active salt mines that are now use by The National Archives because the cool, dry air is good for the documents. Paul Dryburgh, "The Law and Legal Records: An Overview," Postgraduate Archival Training (PAST): Medieval Legal Records Workshop, The National Archives (2018). That archivists have not yet processed and catalogued some of the corresponding legal documentation for the Court of Common Pleas can be problematic, but it also shows how even long after the deaths of the people involved there is still, as Michel-Rolph Trouillot called it, a silencing going on as archivists choose how to, or whether to, preserve records and how to catalogue them (or not). Silencing the Past: Power and the Production of History (Boston: Beacon Press, 1995), 48.

34 This is similar to what happens with Burns' notaries, especially the ones who dealt with indigenous peoples' complaints. As she points out, those rarely made it into the official record because they were seen as unimportant by the Spanish officers. Burns, Into the Archive, 7. Although for the Court of Common Pleas the power differential was not one of colonizer and colonized, the process of translation from the spoken language to the written language was the same.
} 
seeking damages, but also to tell their stories. In some cases, the plaintiffs wanted the wrongs done to them acknowledged, and the perpetrator punished through an award of damages. While this certainly may have felt punitive to the defendant, for the plaintiff, the point may have been less about compensation and more about the reputations involved. This payment for the wrong done to them, while not erasing the original disorder, acted as a corrective measure, effectively restoring order. In addition to this payment, the chance to put forward their narrative of events in a public setting was an important one. This ordering of events was a way for them to defend or assert their reputations as law-abiding, upstanding men and women. In many cases, going to court was also way to force a recalcitrant defendant into arbitration, an agreement by which order and harmony would also be achieved, as well as respective reputations restored.

While the above cases are abrupt, others in the sample provide more insight due to added information about the events or the people. With this extra information, we can see the ways in plaintiffs used allegations of violence to question the validity of documents. For two cases, violence was allegedly used to obtain bonds, or secure written promises, whether by theft or coercion. ${ }^{35}$ According to Alice Spenser's count, Thomas and Margaret Dyns forced her, through violence and imprisonment, to enter a bond of obligation with them, worth twenty pounds. It would seem, then, that the Dynses had such a bond, and that Spenser denied its legitimacy. In another case, Richard Iklyngton accused Richard Kyngeston of stealing a bond (or written agreement) worth ten pounds, eight shillings, and four pence. ${ }^{36}$ For both cases, the defendants pleaded "not guilty" to the force and arms and the breaking of the king's peace aspects of the counts, which was standard language seen in all the cases used in this dissertation, and pleaded a

\footnotetext{
35 TNA, CP 40/619, rot. 597d; TNA, CP 40/607, rot. 380d.

36 This was a bond between the plaintiff, Richard Iklyington and Henry Kyrkeby, another man, and so did not involve the defendant at all, unlike in the Spenser v. Dyns case.
} 
special issue for the rest. According to the defendants' versions, both bonds were freely given. The juries would have been assembled to decide whether the bond was coerced or freely given or if a bond was given voluntarily or not. These special issues were two of the three that did not involve the defendants acknowledging the violence, which calls into question whether certain aspects or the entire event were falsified. We could be looking at a simple financial dispute between Spenser and the Dyns that Spenser then escalated to a violent altercation in order to push the case to a central court. Much of this is speculation, but if that is the case, this would be a classic example of using trespass vi et armis as a legal fiction. Regardless, Spenser's case illustrated a believable scenario; that Spenser, through this case, thought she might be successful in court suggests that people violently forced to enter into debt was not an unheard-of phenomenon.

Accusing someone or several people of assault meant that the plaintiffs did not need to fictionalize trespass vi et armis; although they had to make the decision to pursue the wrong as a civil allegation as opposed to a criminal one. This does not mean, however, that the plaintiffs were being truthful. These cases could be examples of the escalation of non-violent disputes into violent altercations. Plaintiffs could have started malicious lawsuits designed to smear the defendant's reputation and cost them money. ${ }^{37}$ Or, they could have been real assaults. Even if they were a part of a larger dispute, that does not negate the fact that an assault might have occurred. In two of the cases, that the victim of the assault was the servant or apprentice may indicate that there was a larger dispute between the masters, who were the litigants. ${ }^{38}$ Three cases

\footnotetext{
${ }^{37}$ Maddern provides examples of both of these occurring in East Anglia. While she has other evidence such as private correspondence to illustrate these ulterior motives, I do not. While there could certainly be a possibility of machinations outside of court, there is not proof of it for these cases. Philippa C. Maddern, Violence and Social Order: East Anglia 1422-1442 (Oxford: Oxford University Press, 1992), 32.

38 TNA, CP 40/615, rot. 656; TNA, CP 40/579, rot. 059.
} 
where the victim of the assault was female could be further examples of people caught up in the disputes of others. ${ }^{39}$ In one of these cases, while there were accessories listed, the main defendant was a man. Agnes Waryn accused Hugo Taillour of assault. ${ }^{40}$ Being a lone female plaintiff suggests that, in this instance, the dispute was between Waryn and Taillour. In the Swyft v. Pope case discussed below, Petronilla Swyft, the sole plaintiff, was still identified through her marital relationship, which is not happening in the Waryn $v$. Taillour case. ${ }^{41}$ In both cases, the defendants pleaded "not guilty."

Another case, from 1411, in which the defendant denied the assault and violence, but pleaded a special issue on the other wrongs, provides further insight into how complicated even alleged violence could be. Each of the three alleged wrongs had a different victim: the assault was against one of the plaintiffs, Alicia Power, a servant was abducted, Nicholas Lye, and goods were stolen from Alicia and her husband, William, the other named plaintiff. ${ }^{42}$ Richard atte Chirche, the defendant, pleaded "not guilty" on the assault and pleaded a special issue for both the theft and abduction. In atte Chirche's plea he described a long-running dispute over the disposition of the last will and testament of John atte Lye. This is another case where it was more than likely a non-violent dispute over distribution of goods to pay debts and satisfy a will that was escalated using the trespass vi et armis fiction. Richard atte Chirche won the day for this case, but not because a jury found him innocent. The plaintiffs failed to follow through with their suit, which resulted in the case being dismissed. This might indicate the parties reached an outside agreement. ${ }^{43}$ If atte Chirche was the more faithful in his accounting of events, it suggests

\footnotetext{
39 TNA, CP 40/583, rot. 274; TNA, CP 40/579, rot. 160; TNA, CP 40/606, rot. 236d.

40 TNA, CP 40/583, rot. 274.

41 TNA, CP 40/598, rot. 345. In Swyft v. Pope it reads as "Petronille que fuit uxor Willelmi Swyft." This does not happen in Waryn's case.

42 TNA, CP 40/602, rot. 116 d.

${ }^{43}$ Maddern, Violence and Social Order, 42.
} 
that the dispute over the will was the motive behind the action. Even if the plaintiffs falsified part or all of their suit in order to move the case to a central court, this case illustrates multiple possible strategies by litigants, including possible arbitration and issues over reputation. ${ }^{44}$

\section{Machinations of Defendants}

The same problems of crafting a narrative occurred for the defendants as well as the plaintiffs. Not only did what the defendant(s) said in court go through the same filtering and translation process as what the plaintiffs said, but defendants also had to fit their narrative into one of the four pleadings available to them: general issue, special issue, demurrer, or "confession and avoidance". ${ }^{45}$ In court, the defendant would tell their version of events, again, most likely in English, or at least they would tell the version of events they wanted the courts to know. There was probably an element of fictionalization here, too. But this story was not what was recorded in the plea rolls. The justices, attorneys, and serjeants at law would dissect the defendant's narrative, arguing over the point, or issue, which would then become the basis for the trial. Therefore, only part of the story was recorded or focused on and inserted as it could be between the formulaic Latin phrases required by the courts. Regardless of what either litigant said in court, there was a particular way it had to be recorded. As Shannon McSheffrey explains, both the plaintiff and the defendant gave accounts of what they "wanted to pretend had happenedyet sometimes had not happened at all, or at least not as recorded in the document. In being archived, however, those aspirational documents in a sense become what happened." 46

\footnotetext{
44 Both of these types of motives will be discussed in subsequent sections of the chapter.

${ }^{45}$ I discuss these in more detail in chapter two. Baker, An Introduction to English Legal History, 91-92.

46 McSheffrey, "Detective Fiction in the Archives," 66.
} 
Table 1 - Details for Cases About Damages and Reputation

\begin{tabular}{|c|c|c|c|c|c|c|c|}
\hline Case Name & Term, Year & Torts & $\begin{array}{l}\text { Date of } \\
\text { Tort }\end{array}$ & Damages & Plea & Concluded & TNA Reference \\
\hline Bremore v. Rose & $\begin{array}{l}\text { Michaelmas, } \\
1413\end{array}$ & $\begin{array}{l}\text { Assault } \\
\text { Taking of Goods }\end{array}$ & $3 / 21 / 1412$ & $£ 60$ & $\begin{array}{l}\text { Not } \\
\text { Guilty }\end{array}$ & No & CP 40/611, rot. 457 \\
\hline $\begin{array}{l}\text { Cheseman } v . \\
\text { Treweman }\end{array}$ & $\begin{array}{l}\text { Michaelmas, } \\
1415\end{array}$ & $\begin{array}{l}\text { Assault } \\
\text { Housebreaking } \\
\text { Taking of Goods }\end{array}$ & $8 / 6 / 1415$ & $£ 10$ & $\begin{array}{l}\text { Not } \\
\text { Guilty }\end{array}$ & No & $\begin{array}{l}\text { CP 40/619, rot. } \\
179 d\end{array}$ \\
\hline $\begin{array}{l}\text { Dullyngham v. } \\
\text { Symond }\end{array}$ & $\begin{array}{l}\text { Michaelmas, } \\
1413\end{array}$ & Abduction & $12 / 29 / 1408$ & $£ 40$ & $\begin{array}{l}\text { Special } \\
\text { Issue }\end{array}$ & Yes & CP 40/611, rot. 124 \\
\hline Eton v. Wodecok & Hilary, 1414 & Abduction & $5 / 5 / 1410$ & 20 & $\begin{array}{l}\text { Special } \\
\text { Issue }\end{array}$ & No & CP 40/612, m. 441 \\
\hline $\begin{array}{l}\text { Hamme v. } \\
\text { Ramsey }\end{array}$ & Easter, 1412 & $\begin{array}{l}\text { Housebreaking } \\
\text { Taking of Goods }\end{array}$ & $12 / 20 / 1408$ & 100 & $\begin{array}{l}\text { Special } \\
\text { Issue }\end{array}$ & No & $\begin{array}{l}\text { CP 40/605, rot. } \\
318-318 d\end{array}$ \\
\hline $\begin{array}{l}\text { Lenham } v . \\
\text { Kentyssh }\end{array}$ & Trinity, 1405 & Taking of Goods & $7 / 8 / 1402$ & $£ 40$ & $\begin{array}{l}\text { Special } \\
\text { Issue }\end{array}$ & No & CP 40/578, rot. 116 \\
\hline $\begin{array}{l}\text { Nyweport } v . \\
\text { Ulnus }\end{array}$ & Easter, 1411 & $\begin{array}{l}\text { Abduction } \\
\text { Taking of Goods }\end{array}$ & $3 / 24 / 1410$ & $\begin{array}{r}£ 66613 \mathrm{~s} \\
3 \mathrm{~d} \\
\end{array}$ & $\begin{array}{l}\text { Special } \\
\text { Issue }\end{array}$ & No & CP 40/601, rot. 139 \\
\hline Prys v. Goodman & Trinity, 1406 & Taking of Goods & $3 / 18 / 1402$ & $£ 20$ & $\begin{array}{l}\text { Special } \\
\text { Issue }\end{array}$ & No & $\begin{array}{l}\text { CP 40/582, rot. } \\
102 \text { d }\end{array}$ \\
\hline $\begin{array}{l}\text { Puddyng } v . \\
\text { Tegaryende }\end{array}$ & Trinity, 1406 & Assault & $3 / 25 / 1406$ & $£ 40$ & $\begin{array}{l}\text { Special } \\
\text { Issue }\end{array}$ & No & $\begin{array}{l}\text { CP 40/582, rot. } \\
412 \text { d }\end{array}$ \\
\hline Pytard v. Fissher & Trinity, 1410 & $\begin{array}{l}\text { Assault } \\
\text { Taking of Goods }\end{array}$ & $5 / 23 / 1410$ & $£ 2613 \mathrm{~s} 4 \mathrm{~d}$ & $\begin{array}{l}\text { Not } \\
\text { Guilty }\end{array}$ & No & CP 40/598, rot. 475 \\
\hline Raven v. Freman & Hilary, 1412 & Abduction & $6 / 29 / 1406$ & $£ 40$ & $\begin{array}{l}\text { Special } \\
\text { Issue }\end{array}$ & No & CP 40/604, rot. 124 \\
\hline Ros v. Michell & Hilary, 1415 & Assault & $7 / 4 / 1414$ & $£ 100$ & $\begin{array}{l}\text { Special } \\
\text { Issue }\end{array}$ & No & CP 40/616, rot. 247 \\
\hline $\begin{array}{l}\text { Spencer v. } \\
\text { Dupham }\end{array}$ & Trinity, 1406 & $\begin{array}{l}\text { Abduction } \\
\text { Taking of Goods }\end{array}$ & $2 / 8 / 1406$ & 40 & $\begin{array}{l}\text { Special } \\
\text { Issue }\end{array}$ & No & CP $40 / 582$, rot. 412 \\
\hline $\begin{array}{l}\text { Walden v. } \\
\text { Blackbourne }\end{array}$ & Easter, 1412 & $\begin{array}{l}\text { Housebreaking } \\
\text { Taking of Goods }\end{array}$ & $2 / 5 / 1412$ & $£ 6613 \mathrm{~s} 4 \mathrm{~d}$ & $\begin{array}{l}\text { Special } \\
\text { Issue }\end{array}$ & No & $\begin{array}{l}\text { CP 40/605, rot. } \\
334 \mathrm{~d}\end{array}$ \\
\hline Whita v. Danbere & Trinity, 1414 & Imprisonment & $4 / 10 / 1414$ & $£ 40$ & $\begin{array}{l}\text { Special } \\
\text { Issue }\end{array}$ & No & $\begin{array}{l}\text { CP 40/614, rot. } \\
357 \mathrm{~d}\end{array}$ \\
\hline Whitby $v$. Wyrale & Trinity, 1413 & Taking of Goods & $12 / 19 / 1399$ & $£ 10$ & $\begin{array}{l}\text { Special } \\
\text { Issue } \\
\end{array}$ & No & $\begin{array}{l}\text { CP 40/610, rot. } \\
204 d\end{array}$ \\
\hline
\end{tabular}

*In this table, I have outlined the cases from this section of chapter three. Defendants could enter four types of pleadings, those pleading "not guilty" entered a general issue. Those who disputed a point in the plaintiffs count, entered a special issue plea.

Going to court also offered a way for the defendant to deny the disorder. In many of the cases discussed below, at least one of the defendants pleaded a special issue, which could focus on one of several parts of the plaintiff's count. Another way of reordering the narrative of the event involved defendants arguing that they had already reached an agreement over the licitness of the act, thus restoring order, through arbitration. ${ }^{47}$ Other defendants either rationalized their actions through a special issue or demurred against the plaintiff's narrative in their pleading.

\footnotetext{
${ }^{47}$ There is no evidence in these cases that the litigants underwent arbitration that was legally binding and carried a penalty for non-adherence. See Edward Powell, "Arbitration and the Law in England in the Late Middle Ages (The Alexander Prize Essay)," Transactions of the Royal Historical Society 33 (1983); Edward Powell, "Settlement of Disputes by Arbitration in Fifteenth-Century England," Law and History Review 2, no. 1 (1984).
} 
While we might think focusing on a technicality, or demurring, was a way for them to 'play' the system, many of the pleadings entered by the defendants deal with crafting a narrative of order in a similar way that the plaintiffs' narratives did. Of course, defendants wanted to avoid paying the damages, but they also wanted to put forward their own version of the events. These defendants offered alternative narratives, ones that did not deny the disorder; instead, they wanted to make a particular point in their defense in light of the original complaint.

However, one strategy that I do not want to overlook which might have been employed by a savvy defendant was the "not guilty" plea. Of the eighty-two cases at the core of this dissertation, defendants pleaded "not guilty" for at least one of the wrongs for which they were accused in forty-five cases. That is roughly 54.8 percent of the cases. Although that number goes down slightly if one only considers cases in which defendants pleaded "not guilty" to all of the accusations: forty out of eighty-two cases or 48.7 percent. Pleading "not guilty" could achieve a myriad of outcomes, but here I want to focus on two possibilities. First, it could pressure a stubborn plaintiff to agree to arbitration by the threat of a lengthly process to get to trial or by allowing the defendant time to bribe officials and jury members. ${ }^{48}$ In eighteen of the eighty-two cases, the sheriff did not send the writ to impanel the jury, thus elongating the length of time the parties were in litigation with one another. In at least four of the cases, the sheriff failed to send the writ on multiple occasions ${ }^{49}$ Conversely, it could also allow for the plaintiff time to corrupt

\footnotetext{
${ }^{48}$ For more on this, see Margaret Hastings, The Court of Common Pleas in Fifteenth Century England: A Study of Legal Administration and Procedure (Ithaca: Cornell University Press, 1947), 217-30.

${ }^{49}$ For example, in TNA, CP 40/582, rot. 412d., the sheriff failed to send the writ five times thus keeping the case going for over a year. In Latin, this reads: "Et qui nec etc ad recognoscendum etc quia tam etc ad quam dies venit partes etc et vicicomiti non misit brevis etc. Ideo sicut prius preceptum est vicicomiti quod venire faciant hic in octabis sancti hillari xii etc ad recognoscendum in forma praedicta etc ad quod dies venit partes etc et vicicomiti modo non misit brevis etc ideo sicut pluriam preceptum est vicicomiti quod venire faciant hic a die pasche in xv dies xii etc ad recognoscendum in forma praedictam etc ad quem diem venit partes etc et vicicomiti non misit brevis ideo sicut pluriam preceptum est vicicomiti quod venire faciant hic in octabis sancti Michaelis xii etc ad recognoscendum in forma praedicta etc ad quem diem venit partes etc et vicicomiti non misit brevis ideo sicut pluriam preceptum est vicicomiti quod venire faciant hic in octabis sancti Hillari xii etc ad recognoscendum in forma praedicta etc ad quem diem venit partes etc et vicicomiti non misit brevis ideo sicut pluriam preceptum est vicicomiti quod venire faciant
} 
possible jury pools. Second, while the wheels of justice continued to turn, defendants would have time, if they had the money as well, to obtain writs from Chancery either halting the proceedings, or initiating new actions against the plaintiff(s).

Three cases between 1410 and 1415, in which the plaintiffs alleged assault as well as theft of goods, might serve as examples of strategic "not guilty" pleadings. ${ }^{50}$ Theft and housebreaking were probably the most likely to fall under the category of using trespass vi et armis to increase the wrong so that it fell under the purview of the central courts because accusations of theft could be brought before a local court. Theft is an interesting type of wrong as it could be pursued as a felony, a misdemeanor, or as a trespass. The value of the goods is how legal courts distinguished between a felony or misdemeanor. The same served to distinguish whether it was a central court or a local court which entertained the trespass action. However, one could pursue theft using civil procedures without alleging force and arms or breaking of the king's peace. Furthermore, in my dissertation dataset, housebreaking, while considered a violent act, never appeared without theft, but in only three instances did a case concerning housebreaking also include assault in the allegations. Each defendant pleaded "not guilty" and none of the cases offered a resolution, at least not one recorded in the Common Plea rolls. In one of the cases, the alleged assault was against the plaintiff; however, in the other case the alleged assault was on a servant. According to John Bremore's count, four men, William Rose, John Boys, Thomas Marleburgh, and Thomas Hieline, assaulted his servant, John Leman, and stole forty pounds in cash. Even with the expanded information from the original writ, it is unclear whether they beat Leman during the commission of what would today be classified as a strongarm robbery or whether these were two distinct events. Was Leman carrying the cash on him?

\footnotetext{
hic in octabis sancte Trinitatus xii etc ad recognoscendum in forma praedicta etc."

50 TNA, CP 40/611, rot. 457; TNA, CP 40/598, rot. 475; TNA, CP 40/619, rot. 179d.
} 
Was he in Bremore's house when the men came in to burglarize the place? However, that the four men pleaded "not guilty" suggests a coordinated strategy to derail Bremore's action in some way; or could be that the four men really were innocent of the accusations.

The same ambiguities as to the sequence of events appears in the other two cases where the plaintiff alleged both assault and theft. In each case, one male and one female defendant were accused of assaulting and stealing from a lone, male plaintiff. ${ }^{51}$ Neither count explained whether the woman and man were both a part of the assault or whether one allegedly assaulted the victim while the other stole the goods. In terms of legal culpability, there would have been no distinction; however, knowing this would illuminate more about gender and violence in the Middle Ages. This is another difference between these cases and Bremore v. Rose, while it was cash allegedly stolen in the first instance, these two cases included a list of goods taken. This makes it more likely that a home, or perhaps business, was the site of the theft and assault. It is interesting to note that in one case the assault was discussed before the theft, which suggests that for one plaintiff the theft was more important than the assault. In only one other case, again Bremore v. Rose, did the count discuss the theft before the assault, which might illustrate that Bremore felt more keenly the loss of his money and was less worried about the violence done to his servant. Of course, this could only be a quirk of that particular clerk rather than a conscious decision by the plaintiffs. These cases illustrate that violence might have occurred as people went about their daily business, perhaps working in a store front when someone decided they did not want to pay for saffron, as in the case of Cheseman v. Treweman. ${ }^{52}$

Many pleadings relied on attempts to excuse actions, as special pleadings, rather than

\footnotetext{
${ }^{51}$ In TNA, CP 40/619, rot. 179d. the pair were clearly identified as husband and wife: Hugo and Joan Treweman. However, in TNA, CP 40/598, rot. 475. the relationship is left unclear, simply listing Ralph Fissher and Joan Weston as the defendants.

52 TNA, CP 40/619, rot. 179d.
} 
deny the accusations themselves. In a couple of cases, the defendants argued in their narratives that a prior assault perpetrated by the plaintiff absolved them from fault for stealing from the plaintiff. ${ }^{53}$ In yet others, the defendants claimed that they were owed money by the plaintiff and so in their defense narratives, they basically asserted that the ends justified the means. These defendants said that the alleged thefts were merely their attempts to recover the monies owed them by the plaintiffs. ${ }^{54}$ This was an action that medieval Londoners might have been familiar with as it was not an uncommon defense and could be attributed to the continuing notion of private justice or a "self-help" mentality of the time. ${ }^{55}$ As scholars such as Barbara Hanawalt and Warren Brown have indicated, there was still a hint of the early medieval ideology of meting out justice by one's own hand, or at least with the help of kin. ${ }^{56}$ These defendants strategically crafted narratives wherein they did not deny their actions, but rather argued that those actions were licit uses of violence. These cases demonstrate that some people, at least, felt that violence in retaliation, or to settle a debt, was justified and open to private parties.

When faced with plaintiffs' attempts to use the courts to test the boundaries of illicit violence, defendants sometimes emphasized what might be called technical issues in modern legal language to argue that the violent act in question was actually licit. Some defenses centered around when a certain action took place. For instance, in the case between Richard Hamme (plaintiff) and Robert Ramsey (defendant), Ramsey defended himself against an accusation of housebreaking and theft by claiming in his plea that at the time of the alleged events the house did not belong to the plaintiff. ${ }^{57}$ Technically, this would mean that Hamme did not have the right

\footnotetext{
53 TNA, CP 40/605, rot. 334d; TNA, CP 40/612, rot. 128.

54 TNA, CP 40/616, rot. 247; TNA, CP 40/578, rot. 116; TNA, CP 40/582, rot. 412.

55 Barbara Hanawalt, 'Of Good and Ill Repute': Gender and Social Control in Medieval England (Oxford: Oxford University Press, 1998), 8; Powell, “Arbitration and the Law," 57.

56 This idea of self-help and the shift in views towards violence is discussed more in chapters one, four, and five.

57 TNA, CP 40/605, rots. 318-318d.
} 
to sue, but Ramsey also points out that his actions were permitted by the true owner, thus they were licit (and probably not violent). In other words, Ramsey claimed it was not theft or housebreaking at all. Along a similar vein, in three cases the defendants countered the allegations against them, all for abduction, by claiming in their narratives that at the time of the supposed abduction, the servants (who were the alleged victims of the abductions) were not actually in active service to the plaintiffs. ${ }^{58}$ These technicalities were important to a case: only the person who owned the house, or who was the legal tenant, and only the master in whose service a person was in at the time of the incident was legally allowed to sue for the wrong. This means if the abducted person was not actually the servant of the plaintiff at the time of the abduction or if the house was not legally the plaintiffs at the time of the theft or break-in, the plaintiffs had no case to pursue. However, it also means the defendants either denied that their actions were illicit violence, or that the actions were violent at all, or glossed over this by arguing only certain people could claim it was an illicit act. In a variation of this, there were a couple of cases where the defendants claimed to have been somewhere else at the time of the alleged abduction. ${ }^{59}$ These special issue pleadings were alibis, which could be construed as the defendant agreeing that the violence was illicit, but that they could not possibly be responsible for the violent act in question.

However, not all disputes centered around whether the violence was licit or illicit, but rather whether the actions of the defendant were acceptable; this occurred between Richard Goodman (defendant) and Thomas Prys (plaintiff) in $1406 .{ }^{60}$ In this case, Prys sued Goodman

\footnotetext{
58 TNA, CP 40/614, rot. 357d; TNA, CP 40/612, rot. 441; TNA, CP 40/604, rot. 124.

59 TNA, CP 40/611, rot. 124; TNA, CP 40/610, rot. 204d. Abduction did not necessarily mean that a person was violently taken against their will. While there were definitely some cases that did deal with being taken against one's will, the majority (and most likely the ones discussed here) were more about enticing apprentices and servants away from their employers/masters. See Caroline Dunn, Stolen Women in Medieval England: Rape, Abduction, and Adultery, 1100-1500 (Cambridge: Cambridge University Press, 2012). for more on this concept.

60 TNA, CP 40/582, rot. 102 d.
} 
for stealing a horse, which Goodman countered had been left in his care long after an agreement they had allegedly made had ended. Prys requested twenty pounds in damages for the horse, valued at four marks, and a saddle, bridle, greaves, and spurs valued together at forty shillings. As per their agreement, according to Goodman, he was free to sell the horse and other items to recoup the cost of upkeep if Prys never came to collect the animal. Prys countered in his narrative that Goodman sold the horse within the first week of having it, never giving Prys the time to come collect the animal. Whether violence actually occurred is in serious doubt in this case as Prys and Goodman seemed to have only come in contact in the initial transaction over the horse. Regardless, Goodman countered Prys's claims of acting outside the law in selling the horse by explaining why his actions were licit. He had, in good faith, kept the horse far longer than the original agreement and felt it had been his right to recoup any financial losses.

Regaining possible lost income was also raised in a last case from the spring of 1411. Richard Nyweport sued Odo of Ulmis, a cleric, for the theft of a chest full of bonds and deeds, which had occurred in London in $1410 .{ }^{61}$ Nyweport's complaint went on to give examples of some of the contracts contained in the chest including a rental agreement and a separate loan agreement. According to Nyweport, one of his servants was also abducted, although that seemed to be of secondary importance to him. Nyweport asked for 1000 marks in damages, a little over 666 pounds, for the loss of the chest, contracts, and the services of the servant. Nyweport was

\footnotetext{
${ }^{61}$ While Newport is a town on the Isle of Wight, the original writ and count from Nyweport makes it clear the chest and servant were in London at the time of the theft and abduction. Here is what it reads as in the original writ: "quandam cistam termino scriptis et aliis munimentis in eadem cista contentis apud London inventa cepit et asportavit et Simonem Richardesservant Nyweport servientem suum in servitis suo ibidem existentem cepit et abduxit" "he took and carried away a certain chest with a fixed-term bond, and other bonds within the contents of the same chest, found in London, and took and abducted Simon, "Richardesservant Nyweport", his servant, being there in this service." And in the count: "ac aliis munimentis in eadem cista contentis apud London in parochia Sancti Stephani in Warda de Walbrok inventa cepit et asportavit et Simonem Richardesservant Nyweport servientem suum in servicis suo ibidem existentem cepit et abduxit." "and other bonds within the contents of the same chest, found in London, in the parish of St. Stephen in the Walbrook Ward, and took and abducted Simon Richardesservant Nyweport, his servant, being there in his service." TNA, CP 40/601, rot. 139.
} 
concerned with the loss of the documents, which detailed his sources of income and records of debts owed, documents which could prove useful if other suits were to arise. ${ }^{62}$ This loss of the documents could present problems for him as a landlord and lender, which might also explain the large amount of money he requested in damages.

And, while Odo of Ulmis went before the court and denied the force and arms part of the complaint, he did not deny taking the chest or abducting the servant. Instead, his defense rested on a technical issue with the writ: Nyweport did not include that Odo was prior of Carisbrooke on the Isle of Wight in the original writ and count laid out against him. Nyweport entered a rejoinder claiming that Odo was a secular cleric at the time of the writ and only became a prior afterward. ${ }^{63}$ If a jury had found in favor of Odo, then the case would have been dismissed; this might have caused Nyweport to either drop the suit all together, or he could bring a new action with the correct information. Most likely, this was a delaying tactic as it does not seem like Nyweport would abandon a suit of this caliber. Of course, in the modern sense, we could just see this as a crafty way to get out of the suit, but why go this route instead of just pleading "not guilty"? That Odo made a point of correcting this demotion from regular clergy to secular clergy in the writ says a lot about what Odo thought was important in the case, a narrative that casted doubt on Nyewport's account. ${ }^{64}$ As a public forum, the courts offered a way to make claims that would then be entered in to the records, be heard by the jury, and thus help establish one's

\footnotetext{
${ }^{62}$ As Clanchy explains in From Memory to Written Record., the written word became ever more important in English society.

63 As a savvy litigant, Odo would have known that benefit of clergy was only available in felony allegations. While, technically, clerics were not allowed to be sued in secular courts, that does not seem to have stopped the practice. Odo would have also known that most common law judges did not adhere to the canonical proscriptions against clergy as defendants. R.H. Helmolz, The Oxford History of the Laws of England, Vol. 1 (Oxford: Oxford University Press, 2004), 508-14.

${ }^{64}$ There is evidence in other courts of people using the system to establish status, whether that be free or villein, which may also be what Odo was attempting; however, in most of those cases the people trying to establish their status were the plaintiffs, not the defendants. See Maddern, Violence and Social Order, 33.
} 
versions of events. Odo's status as regular or secular clergy was also something that might be easier to prove true as there should have been records of when he became the prior at Carisbrooke. And this is the point on which the jury would decide: when did Odo become a prior? ${ }^{65}$ If Odo could show this point to be false, then he could more successfully challenge the rest of Nyweport's claims, thus preserving his narrative as the lasting version. ${ }^{66}$ Odo did not dispute that the violence in question occurred, nor that it was an illicit act.

\section{Pursuing Arbitration}

In the previous two sections of the chapter, I explored ways in which either the plaintiff or defendant might have used the system to achieve the end goal, whether that was finally bringing a long standing dispute to closure or exploiting what might be called a legal loophole in modern parlance to avoid repercussions for an action. While forcing an arbitration was a common motive for plaintiffs bringing an action against someone, defendants, too, raised the issue of arbitration during their pleadings before the court. Arbitration was a time-honored way in which conflicting parties could settle their disputes and people often pursued both arbitration and litigation simultaneously. The ten cases in which defendants referenced arbitration cover an array of torts; four of them were assaults, three were theft of goods, one was an abduction, and two were both thefts and abductions. The defendants in each of these cases claimed that the parties had submitted to arbitration in order to resolve at least one of their disputes: an arbitration that had taken place before the suit was brought to court. Therefore, as they counter in their

\footnotetext{
${ }^{65}$ Odo seems to have been instituted as prior of Carisbrooke on January 12, 1401, so the likelihood that this case would have been dismissed was high. If that was the case, Nyweport would have had the option to start a new trespass action with the correct information about Odo's status. David Knowles, et al., eds. The Heads of Religious Houses: England and Wales, III. 1377-1540 (Cambridge: Cambridge University Press, 2008), 168. I would like to thank Shannon McSheffrey for pointing me towards this information.

${ }^{66}$ After the Statute of Additions in 1413 (1 Hen. V, c. 5) this type of clerical error (if it was indeed a clerical error) would have been grounds for dismissal of the case, as printed in The Statutes of the Realm, vol 2: 1377-1504 (London: 1816), 171.
} 
narratives, the plaintiffs should not be allowed to sue them. ${ }^{67}$

In eight of the ten cases where arbitration was used in the plea, a resolution had come out of the arbitration and had, according to the defendants, been honored. The plaintiffs employed a variety of rejoinders, from admitting to arbitration but arguing it was about a different matter, to denying the arbitration altogether. While they may have marked their agreements through the ceremony involved in arbitration, the defendants did not offer a sealed agreement between the parties; these seemed to have only been an oral agreement between the two parties themselves. In all ten of the cases, the parties did not write down the terms of their agreements nor had they provided mutual securities to ensure each party abided by it; they had themselves and the arbitrators as witnesses, all relying on memory. ${ }^{68}$ This lack of documentation was not uncommon and so was probably not seen as a detriment to the narratives presented in the cases; this was a hallmark of these arbitration defenses. ${ }^{69}$

\footnotetext{
${ }^{67}$ This would, indeed, be true if the arbitrations actually took place. See Powell, "Arbitration and the Law," 56.

${ }^{68}$ According to Edward Powell, by the fifteenth century documenting arbitration was more typical in England than in earlier centuries. For Londoners, this document would probably then be registered with the mayor and aldermen in London as a way of publicly certifying the agreement. I could find no record of this happening in any of the cases discussed in the following pages. See Powell, "Settlement of Disputes by Arbitration"; Hanawalt, 'Of Good and Ill Repute,' 39.

${ }^{69}$ The lack of documentation was not necessarily a detriment or a sure sign the case would fail. Bellamy indicates that most evidence came by way of witnesses rather than written documents. If the jurors either had knowledge of the arbitration themselves or found people who did, then the defense would stand. This is why cases alleging arbitration had the trial in the location where the arbitration allegedly occurred rather than where the violent act occurred. Bellamy, The Criminal Trial in Later Medieval England, 101-102.
} 
Table 2 - Details for Cases in which Defendants Pleaded Prior Arbitration

\begin{tabular}{|c|c|c|c|c|c|c|c|}
\hline Case Name & Term, Year & Torts & Date & Damages & Pleading & Concluded & TNA Reference \\
\hline $\begin{array}{l}\text { Barte v. } \\
\text { Germayn }\end{array}$ & Trinity, 1412 & $\begin{array}{l}\text { Abduction } \\
\text { Taking of Goods }\end{array}$ & $6 / 6 / 1411$ & $£ 20$ & Special Issue & No & CP 40/606, rot. 487d \\
\hline $\begin{array}{l}\text { Gerland v. } \\
\text { Dripol }\end{array}$ & Easter, 1415 & $\begin{array}{l}\text { Assault } \\
\text { Housebreaking } \\
\text { Taking of Goods }\end{array}$ & $5 / 29 / 1413$ & $£ 6613 \mathrm{~s} 4 \mathrm{~d}$ & Special Issue & Yes & CP 40/617, rot. 179 \\
\hline Grey v. Aleyn & Easter, 1415 & Abduction & $1 / 20 / 1408$ & $£ 100$ & Special Issue & No & CP 40/617, rot. 117 \\
\hline Halle v. Kyng & Trinity, 1409 & $\begin{array}{l}\text { Abduction } \\
\text { Taking of Goods }\end{array}$ & $6 / 14 / 1408$ & $£ 10$ & Special Issue & No & CP 40/594, rot. 499 \\
\hline $\begin{array}{l}\text { Jonisson v. } \\
\text { Stokedale }\end{array}$ & Easter, 1415 & Taking of Goods & $4 / 21 / 1413$ & $£ 100$ & Special Issue & No & CP 40/617, rot. 254 \\
\hline $\begin{array}{l}\text { Lorkyn v. } \\
\text { Hankyn }\end{array}$ & Hilary, 1415 & Taking of Goods & $2 / 22 / 1414$ & $£ 2613 \mathrm{~s} 4 \mathrm{~d}$ & Special Issue & No & CP 40/616, rot. 313d \\
\hline Standelf v. Hand & Easter, 1407 & Taking of Goods & $5 / 7 / 1405$ & $£ 40$ & Special Issue & No & CP 40/585, rot. 367d \\
\hline $\begin{array}{l}\text { Swepston v. } \\
\text { Bargon }\end{array}$ & Trinity, 1411 & $\begin{array}{l}\text { Assault } \\
\text { Imprisonment }\end{array}$ & $4 / 4 / 1411$ & $£ 40$ & Special Issue & No & CP 40/602, rot. $171 d$ \\
\hline Ware v. Hervy & Trinity, 1413 & Assault & $4 / 2 / 1413$ & $£ 20$ & Special Issue & No & CP 40/610, rot. 112 d \\
\hline Yonge v. Pensax & Hilary, 1413 & Assault & $10 / 27 / 1404$ & $£ 20$ & Special Issue & No & CP 40/608, rot. 305 \\
\hline
\end{tabular}

*In this table, I have outlined the cases from this section of chapter three. Defendants could enter four types of pleadings, those pleading "not guilty" entered a general issue. Those who disputed a point in the plaintiffs count, entered a special issue plea.

While there were no secular laws governing arbitration there was a customary set of procedures, of which documentation was a definite part. For the most part these procedures seem to have been adapted from canon law, wherein judges were directed to advocate for reconciliation..$^{70}$ In canon law, there were two stages to arbitration: the agreement to arbitrate and the outcome of the arbitration. ${ }^{71}$ By 1350 , these stages had been firmly adopted by people with gentry or nobility status; although as the records discussed later show, these procedures were also adopted and adapted by people of lower status ${ }^{72}$. For secular arbitration, the first stage usually consisted of the disputing parties creating mutual bonds in which they not only agreed to the arbitration within a set time frame, but also to pay a fee if they did not abide by the arbitration. These bonds would have been given to a neutral third party for safekeeping and given back to the disputants only after the arbitration agreement had been settled. ${ }^{73}$ Having agreed to the arbitration, the disputants then usually chose the arbitrators who would negotiate the

\footnotetext{
70 Powell, "Arbitration and the Law," 54.

${ }^{71}$ Powell, "Arbitration and the Law," 55.

72 Powell, "Arbitration and the Law," 55.

73 Powell, "Arbitration and the Law," 63.
} 
settlement; typically these men would be of a similar status to them. ${ }^{74}$ In some instances, they would also appoint, to borrow Joseph Biancalana's word, an umpire, who would step in if the arbitrators failed to reach an agreement. ${ }^{75}$ Once the arbitrators had been agreed upon, they might talk to witnesses, the disputants themselves, as well as examine any documents that supported the various claims. ${ }^{76}$ After this, the arbitrators would discuss the issues at hand and decide on the course of action needed in order to reconcile the disputants. Considerations of status, level of culpability, and any escalations or violent actions would factor into the arbitrators' final decision. For the ten cases discussed in detail below, the fact that the defendants in most were the ones to make reparations indicates that they were in the wrong in those disputes. However, the main point of any arbitration was to return the disputants (and perhaps their communities) to a harmonious status quo. It is perhaps for this reason that most arbitration agreements contained clauses that prohibited the parties from taking the issues arbitrated to court. ${ }^{77}$

The procedures outlined above, of course, presumed that both parties agreed to the arbitration in the first place, which was not always the case. While some historians, such as John Bellamy, once argued that arbitration occurred because the English legal system failed to yield results, others, like Edward Powell and Joseph Biancalana, have shown that throughout the fifteenth century, arbitration was used as a part of an overall litigation strategy by plaintiffs. ${ }^{78}$ In fact, many plaintiffs used the threat of legal action, in the form of obtaining an original writ from

\footnotetext{
74 The disputants could attempt to negotiate amongst themselves or have friends do the negotiations, but most of the cases in this dissertation have litigants who seem to have chosen neutral arbitrators. Biancalana, The Fee Tail and the Common Recovery in Late Medieval England, 349.

75 Biancalana, The Fee Tail and the Common Recovery in Late Medieval England, 349.

${ }^{76}$ Biancalana, The Fee Tail and the Common Recovery in Late Medieval England, 351.

77 Powell, "Arbitration and the Law," 56.

78 J.G. Bellamy, Crime and Public Order in England in the Later Middle Ages (London: Routledge \& Kegan Paul, 1972), 114-19; R.L. Storey, The End of the House of Lancaster (London: Barrie and Rockliff, 1966), 121-22; Powell, "Arbitration and the Law"; Powell, "Settlement of Disputes by Arbitration"; Biancalana, The Fee Tail and the Common Recovery in Late Medieval England.
} 
Chancery for our cases, to pressure their opposition into agreeing to arbitration. Any of the cases, especially those in which the defendant pleaded "not guilty", might be an instance where the litigants were a part of a dispute in which the defendant refused to arbitrate, so the plaintiff added the very real threat of a legal action and the associated costs to entice the defendant to the bargaining table, as it were. Additionally, as evidenced by the conclusion rates of cases before the Court of Common Pleas, a savvy plaintiff would not leave their chances to only a jury trial. In those cases where the plaintiff had not been attempting to arbitrate before bringing the case, the litigants might have mutually agreed to arbitration after that original writ or first appearance. In either event, arbitration often saved the disputants the time and money that going to court would cost them. Even with the mutual benefits of arbitration, it is possible that a disputant was dissatisfied with the outcome of an arbitration settlement and thus decided to pursue the dispute through legal action, if the terms of the arbitration allowed or were unmet. While it is unclear whether the plaintiffs in the following cases were dissatisfied or whether the defendants falsified the arbitration, they still reveal how closely linked litigation and arbitration could be in the fifteenth century.

In the first of the assault cases in which the defendant brought up arbitration, John Pensax was accused of assaulting Richard Yonge some eight or nine years earlier; although Yonge did not claim to have feared for his life, he did ask for twenty pounds in damages. ${ }^{79}$ Pensax went to the court and denied the force and injuries, but claimed in his narration of events that he and Yonge had submitted to arbitration after the assault had occurred. ${ }^{80}$ In a possible strategic move,

\footnotetext{
79 TNA, CP 40/608, rot. 305. The case was before the court in 1413, but Yonge claimed the assault occurred "die lune proximo ante festum Omnium Sanctorum anno regni domini Regis nunc sexto", which would place it happening on October 27, 1404.

${ }^{80}$ The denial of force and injuries is a formulaic phrase that appears in every case that I have used for this dissertation. The only changes to the phrase come with multiple defendants when it becomes plural instead of singular. For this case, it looks like this: "Et praedictus Johannes in propria persona sua venit et defendit vim et iniuriam quando etc." "And the aforementioned John comes in person and denies the force and injuries when, etc."
} 
Pensax did not deny the assault outright, just Yonge's right to sue because of the arbitration that previously settled the problem between the two of them. ${ }^{81} \mathrm{He}$ further claimed to have paid Yonge twenty of the forty shillings the arbitrators decided Pensax owed him. According to Pensax's version of the agreement, the other twenty shillings would have been paid when Yonge released Pensax in writing. ${ }^{82}$ However, in his rejoinder, Yonge dismissed Pensax's claims that they had settled things through arbitration. Yonge's side of the story was that no arbitration took place between the two parties. Yonge's rejoinder and insistence that the arbitration never occurred could be because he desired a larger payday, ten times what he allegedly received as a result of the arbitration. However, this seems unlikely as even in those few cases that did conclude in favor of the plaintiff, they received a fraction of what they asked for. Other possibilities lie in whether Yonge felt that the arbitration adequately addressed the issue of violence, if Pensax had not paid the promised compensation, or if Yonge thought the arbitration had fallen short as a corrective measure and so sought recourse in through litigation.

Similarly, in 1413 John de Ware, cutler, accused Richard Hervy of assault with damages claimed at twenty pounds. ${ }^{83}$ Hervy appeared before the Court of Common Pleas and claimed he was innocent, especially of the force and arms part of the incident. ${ }^{84}$ He then further expanded his defense narrative by stating in his plea that Ware should not be allowed to sue him because after the supposed assault occurred, they had entered into (and concluded) arbitration in Essex. Ware and Hervy each appointed two men to represent them in the arbitration. ${ }^{85}$ These arbitrators

\footnotetext{
${ }^{81}$ It does seem problematic to issue a blanket denial of the force and injuries but then go on to tacitly admit to the assault by arguing that it was settled by the arbitration.

${ }^{82}$ TNA, CP 40/608, rot. 305.

83 TNA, CP 40/610, rot. 112 d.

84 TNA, CP 40/610, rot. 112d: "Et praedictus Ricardus in propria persona sua venit et defendit vim et iniuriam quando etc et quoad venire vi et armis dicit quod ipse in nullo est inde culpabilis..."; "And the aforementioned Richard comes in person and denies the force and injuries when etc, and as for the coming with force and arms he says that he is in no way guilty..."

${ }^{85}$ The four arbitrators were William Harry (brewer) and John Balytre for Ware and Walter More and Richard Rede
} 
decided that Hervy needed to pay Ware thirteen shillings and four pence, which Hervy claimed he did. However, Ware came back to claim in his rejoinder that they did not have arbitration as Hervy alleged. They both agreed to put their conflicting claims to a jury in Essex. Hervy made no attempt to deny the original wrong, the assault, instead he claimed that Ware had already been paid and, therefore, in Hervy's mind this tort was no longer a wrong, and order had been restored. Hervy wanted the courts to agree with him. Without documentation of the agreement or reliance upon securities that they would abide by the terms, neither of which Hervy offered to produce in court, it was down to the word of the two men and perhaps the four arbitrators to validate. The jury in Essex would have been charged with finding answers to these questions, interviewing witnesses, and using their own prior knowledge to decide on the veracity of the claims. It could be that Ware willfully forgot or misremembered the details of the arbitration. Perhaps he wanted more money from Hervy or pushed the issue in the Court of Common Pleas to force another agreement. ${ }^{86}$ If Ware did not feel the arbitration, had it occurred, settled the dispute over the violent act, he may have resorted to the courts in order to gain a more official ruling on the illicitness of Hervy's assault.

The Ware v. Hervy case was typical for arbitration defenses. In many, the defendants claimed to have already paid the plaintiff as a result of that arbitration. In an assault and theft case, one of the few that comes to a conclusion, John Gerland accused John Dripol of breaking into his home in Essex, stealing forty pounds worth of goods, and assaulting him. ${ }^{87}$ Dripol tacitly admitted to these accusations when instead of claiming his innocence, he said that the two of

\footnotetext{
for Hervy.

${ }^{86}$ See chapter two for a more detailed examination of the court costs associated with the Court of Common Pleas. As mentioned earlier, most of the cases before the Court of Common Pleas do not come to a conclusion within its records, most likely because the litigants entered into arbitration to settle the case. For the ones that did, plaintiffs receive a mere fraction of what they requested; Ware would, if he won, have gotten nowhere near forty pounds out of Hervy.

${ }^{87}$ TNA, CP 40/617, rot. 179.
} 
them had undergone arbitration to settle the problems between them. The arbitrators decided Dripol owed Gerland two shillings, which he paid, and therefore Gerland no longer had the right to sue him. ${ }^{88}$ However, this case continued on to a recorded resolution in the plea rolls. A jury decided that they had not undergone arbitration and as a result, Gerland was awarded damages of one shilling and eight pence, not even one percent of the hundred marks Gerland requested in damages. It makes one wonder what the point of the case was. Gerland recovered less, assuming that Dripol paid, than what he spent to bring the case before the Court of Common Pleas. We see this again in a case where John Stokedale was accused of stealing goods from William Jonisson. ${ }^{89}$ Stokedale argued in his narrative that he and Jonisson had submitted to arbitration and that he had paid Jonisson the seven pounds as decided by the arbitrators. ${ }^{90}$ In each of these cases, the plaintiffs could be using a similar strategy as Ware or Yonge; they wanted more money and so purposefully misrepresented the arbitration or they could be telling the truth and the defendants were fictionalizing the events to suit their narrative. That the defendants claimed money exchanged hands as a result of the arbitration might have made a more credible narrative for a jury. These narratives also show how commonly arbitration was used to restore order between two parties after a violent act; this was a story with which juries would have been familiar.

However, not all people claimed to have paid money through their arbitration settlements. Another common result was an exchange of goods; a gallon of wine was listed in at least three of the ten cases. ${ }^{91}$ In one, four defendants were accused by Richard Halle, barber and citizen of

\footnotetext{
${ }^{88}$ If true, Gerland's case would indeed not be admissible as arbitration settlements usually included clauses which prohibited any further action for the arbitrated wrongs. The same would also be true in the Swepston v. Barton case discussed below. Powell, "Arbitration and the Law," 65.

89 TNA, CP 40/617, rot. 254.

${ }^{90}$ William Stowe and William Belle were the arbitrators on behalf of John Stokedale and John Fourbour and Roger Bers on behalf of William Jonisson.

91 These cases were TNA, CP 40/606, rot. 487d; TNA, CP 40/616, rot. 313d; TNA, CP 40/594, rot. 499. Wine was a
} 
London, of theft and of abducting his servant, Lucy Janeman. ${ }^{92}$ Halle claimed the goods taken were worth forty shillings and that he lost the services of Janeman for almost six months. In recompense for these wrongs, Halle requested ten pounds in damages. The defendants, Richard Kyng, Richard Clement, Richard Paynell (all from East Marden in Sussex), and John Barbour, collier and citizen of London, pleaded "not guilty" for the force and arms and for the theft. However, they did not deny abducting Janeman and keeping her for several months. Instead, they said that the following year, all parties entered into arbitration, through which it was decided that the four defendants owed Halle a gallon of wine for his troubles. ${ }^{93}$ Halle denied agreeing to the arbitration, and both sides agreed to submit their versions to a jury in Sussex.

Similar to the Ware v. Hervy case, the defendants in this case accused Halle of either purposefully or mistakenly misleading the court; they did not fully proclaim their innocence. They did not deny that the abduction happened but argued they had already settled it; and according to his rejoinder, Halle was not only denying he agreed to arbitration, but that they had reached an agreement with the defendants handing over a gallon of wine. The defendants in this case outnumbered the plaintiff, but they only had two arbitrators appointed, one for each side, and there is no mention in the pleading that they had written down their agreement, nor that they offered any mutual securities that they would abide by the arbitration. It is not often that conclusions to cases were entered into the records of the Court of Common Pleas and this case is no exception. While the defendants may have felt that the arbitration had restored the order, Halle may have wanted an outside opinion, a more public opinion on the actions of the

common gift, both in the settlement of disputes, and as gifts to visiting dignitaries. See Barbara A. Hanawalt, Ceremony and Civility: Civic Culture in Late Medieval London (Oxford: Oxford University Press, 2017), 83-86.

92 TNA, CP 40/594, rot. 499. This case appeared before the court in 1409.

${ }^{93}$ In this case, Peter North and Nicholas Forster were the arbitrators. Also, it is not clear if that was a collective gallon of wine or a gallon per defendant. 
kidnappers, perhaps in order maintain his reputation.

In another case supposedly involving an exchange of wine, Richard Hand was sued by John Standelf, in 1407, over the alleged theft of twenty pounds worth of goods. ${ }^{94}$ Standelf listed the goods that Hand supposedly took, including sixteen silver-lined girdles and twenty silver spoons. According to Hand, he and Standelf entered into arbitration a few months after the date of the incident. It is quite interesting to note that they appointed one arbitrator per person, but then also had the foresight to appoint an umpire in case their arbitrators could not come to an agreement, which was exactly what happened. ${ }^{95}$ When John Salvayn (appointed on behalf of Standelf) and Thomas Naffirton (appointed on behalf of Hand) reached an impasse, Thomas Molynton, Baron of Wem, stepped in. According to Hand's narrative, the baron decided that Hand owed Standelf a gallon of wine, which Hand claimed he had handed over. That Hand listed as the final arbitrator a nobleman lends credence to his version of events. Considering this outcome, along with Standelf's assertion that Hand stole twenty pounds worth of goods and that he requested forty pounds in damages, it is perhaps not surprising that Standelf denied the arbitration had ever taken place. ${ }^{96}$ It could be that Standelf was pressured into an arbitration and that he did not agree with the notion that private individuals, nobility notwithstanding, should be able to adjudicate violence.

Still, some plaintiffs received neither goods nor money for their troubles. ${ }^{97}$ In 1415 , William Grey accused John Aleyn, a maltman from Canterbury, of abducting Grey's apprentice, John Marchall..$^{98}$ According to Grey, the loss of services cost him twenty pounds and he asked

\footnotetext{
94 TNA, CP 40/585, rot. 367d.

95 This is the only case, out of eighty-two, where this occurred.

96 Of course, going against a nobleman was also a high stakes gamble on Standelf's part.

${ }^{97}$ Whether they requested goods or money during the arbitration is unknown.

${ }^{98}$ TNA, CP 40/617, rot. 117. While the case was in the 1415 Easter plea rolls, the alleged incident occurred on January 20, 1408.
} 
for another one hundred pounds in damages. Aleyn countered this narrative in his plea, arguing that he and Grey had submitted to arbitration sometime after the alleged abduction had occurred. Aleyn claimed that John Glene had served as his arbitrator and that John Bedying, a London tailor, had served as Grey's arbitrator. According to Aleyn's narrative, the arbitrators had decided that Marchall was really Aleyn's apprentice, and that Grey was owed nothing. Grey countered in his rejoinder that he had never submitted to arbitration with the arbitrators John Glene and John Bedying. He did not, however, claim that he had not agreed to arbitration; simply that he had not agreed to use those arbitrators, so Grey was using a technical issue in Aleyn's plea to dismiss his claims. This seems a peculiar thing to do if Grey really had submitted to arbitration with Aleyn; why call into question the names of the arbitrators and not the arbitration itself? As far as strategies go, both Grey and Aleyn might have been crafting their stories as close to the actual events as possible; this could be a delaying tactic or an actual misrepresentation by one of the parties. It could be that Grey knew that jurors would find out about the arbitration, but not necessarily who the arbitrators were, as no documentation was discussed by either litigant.

While any of the litigants in the previously discussed cases might be concerned with their reputations, this next case bridges the gap nicely between arbitration as a strategy and concern for reputation. Robert Swepston and his wife Joan accused John Bargon, a brewer of London, of assaulting and imprisoning Joan. ${ }^{99}$ According to their narrative, Bargon kept Joan for two days. For damages, they asked for forty pounds. This could be the result of a dispute between Bargon

\footnotetext{
${ }^{99}$ TNA, CP 40/602, rot. 171d. Sara Butler and Caroline Dunn have done extensive work on the abduction of wives. In this instance, it was possible that Joan left her husband of her own free-will and only after the fact claimed imprisonment. Or her husband could be claiming she was imprisoned to restore some of his reputation. There could, of course, have been an actual abduction (which may or may not have had a sexual component), but these details are not available to us. See Sara M. Butler, "Runaway Wives: Husband Desertion in Medieval England," Journal of Social History 40, no. 2 (2006); Dunn, Stolen Women in Medieval England.
} 
and Joan's husband and Joan was caught in the crossfire. Even if it was only an incident between Bargon and Joan, her husband would have to appear in order for her to sue. ${ }^{100}$ Bargon appeared in court, in 1411, and denied the force and arms, but not the kidnapping or assault. It is quite possible this is an example of a wife leaving of her own volition and then later claiming assault and imprisonment to spare either her reputation, or her husband's, or both. Instead, Bargon claimed that a few months later they entered into and finished arbitration about these wrongs. Each side chose an arbitrator to represent them and agreed to abide by their decisions. ${ }^{101}$ According to the record, the arbitrators decided that both parties were to kiss and be friends. ${ }^{102}$ Because the details of the arbitration were not recorded, at least not in the case in the Court of Common Pleas, it is unclear whether more accommodations were made, and it was only the agreement that was sealed with a ceremonial embrace, or if that was the entirety of the settlement. However, the Swepstons claimed that the arbitration never happened. This could be because Bargon fictionalized his account to better his defense, or it could be because the Swepstons decided a 'kiss and make-up' situation did not offset the damage done by Bargon's alleged assault and imprisonment. In choosing this defense, Bargon tacitly admitted to the assault and imprisonment by saying that whatever problems that were between them have been resolved. If the only thing to come out of the arbitration was ceremonial recompense, it could indicate the Joan had gone willingly with Bargon. ${ }^{103}$ This arbitration, then, might not have been enough to fully restore the Swepstons' reputation.

\footnotetext{
100 Tucker, Law Courts and Lawyers in London, 234.

${ }^{101}$ In this case, the arbitrators were Henry, parish priest of St. Olave, and Robert Arnold, citizen and grocer.

102 TNA, CP 40/602, rot. 171d.: "oscularent quemlibet eorum alterum et etiam quod essent amici"

103 According to Butler, husbands sued (in the Court of Common Pleas) the accomplices who helped their wives runaway. Dunn talks about husband's using civil actions to "expose a wife's misbehaviour in the royal courts." Although in this instance, it would seem that the couple were already reconciled, so neither conclusion seems valid. Butler, "Runaway Wives," 341; Dunn, Stolen Women in Medieval England, 205.
} 


\section{Damages and Reputation}

The idea of reputation and damages can be seen in this next set of cases as well. In these, as with all cases of trespass vi et armis, the plaintiffs alleged that they had experienced illicit violence and requested damages as recompense for said violent act. For some of these cases the defendants pleaded "not guilty." However, in others, the defendants opted not to address the issue of violence, but rather focused on different, more technical, aspects of the case. There were no categorization or rules for pleading a special issue, a defendant could contest any one point in a plaintiff's suit. Some fall easily into categories or have a commonality like prior arbitration or defending oneself; although these were also special issue pleadings. Others, however, do not. These cases often tell us more about how people thought about reputation than violence, although concepts of violence were certainly present. In some of these cases the defendants asserted that there was an issue of fact wrong in the original writ, or that they had documentation to corroborate their claims. A few of the defendants chose to focus on explaining why, given the circumstances they laid out in their defense, the violence in question was a licit act. And for a few cases, they claimed that their violence was for order, rather than disorder. As each of these cases would be heard in front of a jury of their peers, it came down, once again, to the narrative the defendants crafted in order to call into question all or part of the plaintiff's claims. In some of these narratives, defendants chose to admit part of the wrong in hopes of explaining away the rest of it, but in others, they shifted the focus away from the wrong to an issue in the plaintiff's writ and count.

Similar to Swepston v. Bargon, three of the cases concerned imprisonment. One case had a female plaintiff (Petronilla Swyft) against a male defendant (John Pope) and the other two 
involved all male litigants. ${ }^{104}$ Imprisonment implies some violence occurred and it could be tried as a felony or misdemeanor. ${ }^{105}$ It is quite possible these cases are examples of plaintiffs embellishing the level of violence to get the case moved to a higher court, or the plaintiffs could be fictionalizing the narrative to save their reputation. However, if the defendants had been acting in an official capacity, then that would already be under the purview of the central courts as a suit. ${ }^{106}$ As Philippa Maddern explains, part of the law's function was to decide who was allowed to perpetrate violence and who was not. ${ }^{107}$ Despite this, it seems unlikely that Pope, the defendant in the first case, was acting in any official capacity. Swyft claimed to have been imprisoned for one day and asked for twenty marks in damages. She offered no explanations as to why Pope, a cleric, might have assaulted or imprisoned her, but his status as clergy suggests he was not an official for a secular court. ${ }^{108}$ Whether neighbors noted Swyft's voluntary absence for a day and thus she had to bring a false suit to protect her reputation, or whether Pope really did imprison and assault her, the language in the case would be the same, language a jury would believe if it went that far. This is one of the few cases which altered from the formulaic weapons one often sees by indicating that Pope used a dagger in the commission of his alleged wrongs. ${ }^{109}$ The deviation from the formulaic weapons suggests that this was a real weapon used.

\footnotetext{
104 TNA, CP 40/598, rot. 345; TNA, CP 40/597, rot. 128; TNA, CP 40/619, rot. 359.

105 If a person went willingly, there was probably no violence at all. However, given that the alleged victims sued over the incident, it is unlikely that they went with their captor without a fight. Alan Harding, The Law Courts of Medieval England (London: Allen \& Unwin, 1973), 67.

106 Maddern, Violence and Social Order, 71.

107 Maddern, Violence and Social Order, 72.

${ }^{108}$ I was unable to find evidence that Pope worked for any London court.

109 According to Swyft, Pope used a staff and a dagger (baculis et cum uno daggere). TNA, CP 40/598, rot. 345.
} 
Figure 1 - Breakdown of Cases by Weapons Listed

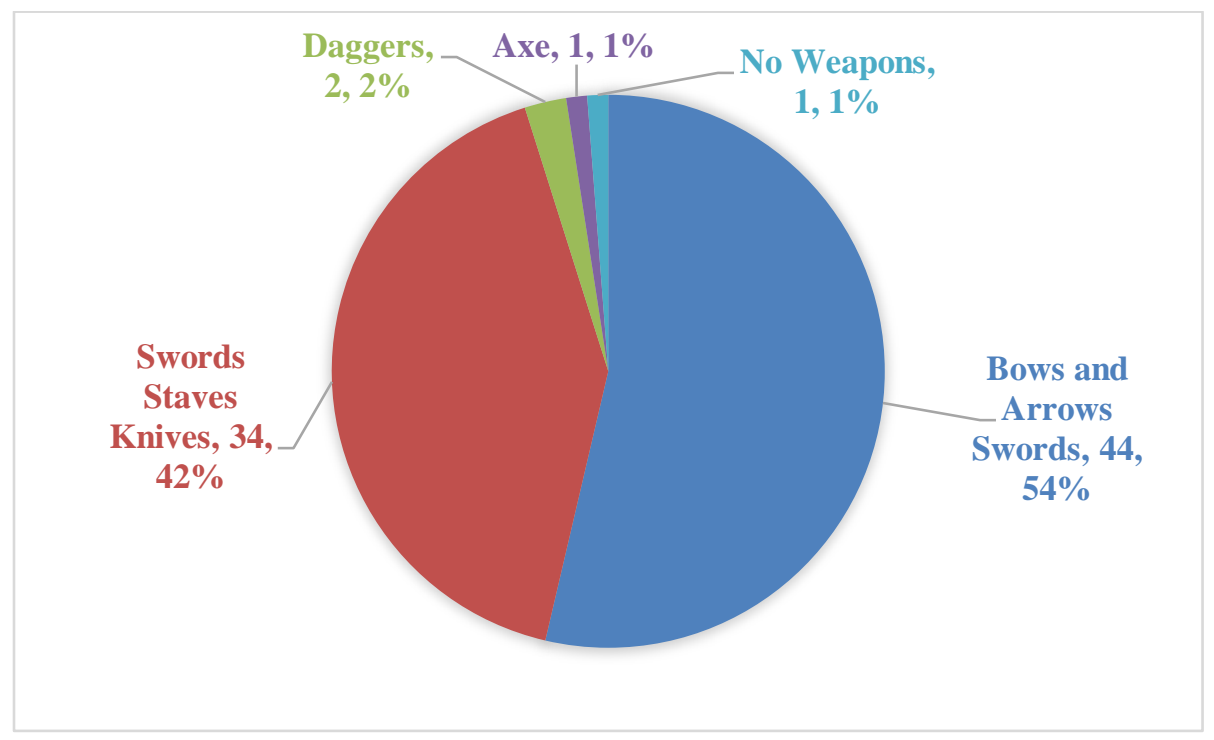

Conversely, the second case maintained the formulaic weapons: swords, bows and arrows. ${ }^{110}$ Lewis Rynfeld, according to his count, was assaulted and then imprisoned for three months by Thomas Shyftling, and he was only released after he paid a ransom of forty shillings. What makes this case even more of an enigma is that the alleged kidnapping took place in 1395 but the case was before the Court of Common Pleas in 1410. ${ }^{111}$ While it might have been possible that Shyftlyng was acting as an official representative of a court of law and that Rynfeld was actually in gaol and had to pay a bond, I was unable to trace Shyftlyng to any court of London. By going to court, Rynfeld illustrated that he felt it was a wrongful imprisonment. Either way, Rynfeld, like Swyft, accused someone of a wrong that did not need to be embellished to get the suit before a central court. In the third case dealing with assault and

\footnotetext{
${ }^{110}$ It is interesting to note that Maddern's work in the King's Bench records returned information that a bow and arrows was a relatively rare weapon whereas in the Court of Common Pleas cases they account for over half of all the weapons listed. Maddern, Violence and Social Order, 29.

111 The clerk also seems to have made an error in noting the location of the wrong. According to the record, it took place in St. Andrew in Cornhill in Farthing Ward. However, there is/was no Farthing Ward and while John Stow notes that St. Andrew Undershaft was also known as St. Andrew upon Cornhill, it was located in Aldgate Ward, according to the Agas map. For the purposes of mapping the wrongs and statistical analysis, I have used St. Andrew Undershaft in Aldgate Ward as the location. "Civitas Londinum (1562?)." The Map of Early Modern London (2012): https://mapoflondon.uvic.ca/agas.htm.
} 
imprisonment, Hugo Wyse accused seven men of assaulting him and making him fear for his life to the point that he could not leave his home for three months. In this instance, five of the men pleaded "not guilty" while two of them pleaded a special issue. ${ }^{112}$ John Cok and John Carpenter denied the imprisonment but admitted to the assault because they counterclaimed that Wyse had attacked them and that they were only defending themselves. However, that Rynfeld and Wyse chose to pursue their cause as a civil action rather than an appeal of a felony could indicate that they were interested in compensation for the alleged violence done to them. Going to court in the first place suggests that Wyse and Rynfeld might have been concerned with their reputations in a way that a public court hearing might allay. Additionally, given the time difference between the date of the event and the action, Shyftlyng might have chosen to plead "not guilty" in the hopes that jurors' memories would be less clear of the particulars and the self-defense strategy might play on prominent social mores. ${ }^{113}$

The two other cases in which a female was the alleged victim of assault involved male and female litigants on both sides, which makes it more difficult to ascertain who the main participants were. ${ }^{114}$ Both sets of plaintiffs were married couples, so it remains unclear whether the husband was present during the assault, although it seems unlikely. ${ }^{115}$ There is no indication in the count that the husband attempted to intervene or was restrained from intervening in anyway during the assault. Perhaps it is anachronistic to think this would be the case, but ideas of family governance do suggest that the male head of household should attempt to protect the other members from attack. ${ }^{116}$ Therefore, these cases could be examples of disputes between the men

\footnotetext{
112 TNA, CP 40/619, rot. 359.

${ }^{113}$ Wyse v. Cok and the concepts of self-defense as a strategy will be discussed in more detail in chapter four.

114 TNA, CP 40/579, rot. 160; TNA, CP 40/606, rot. 236d.

115 Married women had to listed alongside their husbands as a result to coverture rules, which I discuss in more detail in chapter five.

${ }^{116}$ Emily Compton, "Property, Propriety, and Patriarchy: Abduction, Assault and Housebreaking in the Court of Common Pleas, 1399-1500,” master's thesis, (The University of Guelph, 2014), 60-61.
} 
involved, which spilled over to their friends and family. Or they could be examples of disputes between the women involved. In the counts from the plaintiffs, there was no indication of who among the defendants did what, so it is unclear whether one or more were lookouts and only one took part in the assault or if they all took turns. Because of the cost to sue before the Court of Common Pleas, it seems unlikely (although not impossible) that people would bring forward malicious lawsuits. If Margaret Mehoure had not been assaulted and she and her husband, John, decided to maliciously sue Katherine Godfray and John Matishale, it would have cost them roughly five shillings. ${ }^{117}$ And what would they gain from this? Perhaps, for some of these cases at least, the litigants were more concerned with reputation than with cost. It would explain why they were willing to pursue costly litigation in a central court.

Perhaps the best example of using a defense to not only refocus a case away from the violence, but also to demonstrate issues of reputation comes from 1411. John Niandesere and his wife, Margaret, sued John Gossefeld for the theft of Margaret's goods which allegedly occurred in July of $1403 .{ }^{118}$ Gossefeld supposedly stole assorted items of jewelry valued at forty pounds and the Niandeseres asked for another 100 marks, or sixty-six pounds, thirteen shillings, and four pence, in damages. ${ }^{119}$ That the couple had pursued this over the course of several years says quite a bit about their concern for their property and reputation. Eight years maneuvering in any court would become a costly venture; if they had been in court for the previous eight years, this could explain the high amount of damages requested. Even if they had not been in court consistently over the intervening years and had just brought Gossefeld before the courts for the first time, an eight-year gap between the alleged theft and court appearance still says a lot about the

\footnotetext{
117 TNA, CP 40/606, rot. 236d.

118 TNA, CP 40/600, rot. 129d.

119 This amount likely includes the value of the goods and court costs, as there was no way to recover the goods with a trespass vi et armis action.
} 
Niandeseres' resolve. ${ }^{120}$ Perhaps this concern had to do with the value of the property; forty pounds was no small sum. Remember, we do not know that a theft actually occurred, the Niandeseres only alleged that Gossefeld stole Margaret's jewelry; they could have been lying. However, the narrative that Gossefeld crafted had less to do with proving his innocence than with casting doubt on the Niandeseres' ability to sue.

Gossefeld came to the court and denied the force and arms and the breaking of the peace, but he did not deny taking Margaret's goods. Instead, Gossefeld claimed that the Niandeseres could not sue him because he had an agreement sealed by the male parties involved in this suit, essentially a liability release. Gossefeld had the document in court; a document, sealed in 1410, in which John Niandesere "remitted, released, and forever quitclaimed the aforementioned John Gossefeld...all manner of personal [actions] he had against him or might in any way have from the beginning of the world until the day of the making of the aforementioned writing." ${ }^{121}$ This might have been as part of an arbitration settlement, although neither the plaintiffs nor defendant reference an arbitration as having occurred. In this case, the court would safeguard the document while awaiting the trial to decide the veracity of Gossefeld's quitclaim. The Niandeseres were concerned with both the recovery of money and their reputations. However, Gossefeld shifted the focus away from the violent act itself and onto the question of whether he was still culpable for the theft in question. We have already seen that arbitration was a common enough way to

\footnotetext{
${ }^{120}$ Given the context of this case, it is more likely that they were not in court over the duration, but rather brought the case to court in 1411. In July of 1403, Margaret was recently widowed and was highly eligible as a marriage partner. During the aftermath of the death of her husband Roger, Lord Scope, a number of men were supposedly in and around her household. This could be when the alleged theft occurred. Eventually, she married John Ninezergh (also spelled Nyandeser), sometime in 1405 or 1406, under somewhat dubious circumstances. Ninezergh continually had run-ins with the law and so may have been trying to recoup money to finance these costs. See Carole Rawcliffe, "Ninezergh, John (d. 1420), of Ninezergh, Westmld.," in The History of Parliament: the House of Commons, 13861421, ed. J.S. Roskell, Linda Clark, and Carole Rawcliffe (Suffolk: Boydell \& Brewer, 1993).

121 TNA, CP 40/600, rot. 129d.: "remisit relaxavit et imperpetuum quietum clamavit praefato Johanni Gossefeld per nomen Johannis fitz Johannes omniodas personales quas erga eum habiut seu quouismodo habere posset a principis mundi usque in diem confeccionis scripti praedicti."
} 
handle negotiations of violence outside of the courts, but a quitclaim was something different. This was more like a "get out of jail free" card. However, it was another way in which private parties regulated violence without resorting to the crown, although it was often the product of arbitration. That people sought redress for violence outside of the courts suggests that they were not willing to either increase the crown's coffers or give up autonomy about issues of licit and illicit violence.

In a similar vein to Gossefeld's defense, there were other defendants who attempted to shift the focus away from the violence using various defense strategies in their narratives. This also served the dual purpose of working to establish, or re-establish, their reputations. These could run the gamut of claiming that the stolen item was freely given, which was the narrative used by Richard Kyngeston when he was sued for theft by Richard Iklyngton, to the goods belonged to their deceased spouse. ${ }^{122}$ Alice Wiltshire and Richard Berle used this defense, as outlined at the beginning of the chapter. ${ }^{123}$ In both cases, the defendants do not deny the violent act, the theft, but their defenses do try to keep them from being labeled a thief. In the case of Wiltshire and Berle, their actions as represented in their narrative also hint at concepts of selfhelp. Neyr was supposed to give the items back to the Wiltshires, which he failed to do, so Alice Wiltshire took them as she felt she had a right to do. While Kyngeston was claiming there was no violence, illicit or otherwise, Wiltshire and Berle claimed theirs was a licit act, violence notwithstanding.

Worrying for their reputations may have been the precipitating factor driving both

\footnotetext{
122 TNA, CP 40/607, rot. 380d. A similar defense was used by Dyns in Spenser v. Dyns, which I talked about in more detail in chapter three. TNA, CP 40/619, rot. 597d. Thomas Burton used a slightly different defense in that he argued someone else had sold him the goods, namely Thomas May's wife in TNA, CP 40/616, rot. 480.

123 TNA, CP 40/582, rot. 219.
} 
Nicholas Stodley and Richard Cularn to court. ${ }^{124}$ In these two cases, the plaintiffs each accused multiple men of assault. For Stodley, the aftermath of the assault included fearing for his life. ${ }^{125}$ Fearing for one's life as a result of being assaulted was not outside the realm of possibility; indeed, two other plaintiffs included it in their cases. ${ }^{126}$ That there were only three cases also suggests that it was not a usual part of assault cases, at least in this time period. If their tales were to be believable, it seems likely that plaintiffs would not push the boundaries of what their peers understood of society and violence, namely that assault could cause fear. Having experienced that fear and removing themselves from society as a result also suggests that these men needed to take their alleged attackers to court in order to restore their reputations, either personal or professional. The other cases discussed so far illustrate that both servants and women could be the victims of violence, not an altogether surprising pronouncement. Although in two cases, women were also alleged perpetrators of that violence. Those narratives that seem more unlikely risked being deemed malicious and unfounded. Whether it was concern for reputation or a desire to see justice served, that all of these plaintiffs undertook the burden of suing in the Court of Common Pleas indicates their reputations or the quest for recompense was important to them.

\section{Conclusion}

Again, the majority of these cases do not come to a conclusion within the Court of Common Pleas records, but they do say much about concepts of order and reputation, notions of licit and illicit violence, and various strategies pursued by litigants. In each case, both the plaintiffs and defendants provided a narrative of the events, with the plaintiff adding monetary

\footnotetext{
124 TNA, CP 40/615, rot. 445d; TNA, CP 40/592, rot. 332.

125 TNA, CP 40/615, rot. 445d.

126 TNA, CP 40/576, rot. 250; TNA, CP 40/619, rot. 359. These cases will be discussed in more detail in chapter four.
} 
damages as part of the restoration of order. The defendants then countered with either a technical point or justification for the disorder, asserting their own ordering to the narrative of events. Additionally, the money the plaintiffs asked for as damages was important. ${ }^{127}$ The damages illustrated how they valued themselves and their property. It was also, if paid, a way to return to the status quo of before the wrong occurred. And while we do not know if any of these men actually received the damages, or had to pay out damages, the narratives they crafted in order to win the case have endured, even when those outcomes have not. ${ }^{128}$

For the ten cases in which the defendant introduced previous arbitration into their defense narratives, the defendants argued that there was no longer a wrong for which they needed to answer. They claimed that it had been corrected previously and that the plaintiff was, at the least, misrepresenting the facts to suit themselves. Arbitration itself suggests that negotiations over licit and illicit violence did not need to happen only with the crown, it could also happen between private parties. In turn, in each case, the plaintiff counter-claimed in their rejoinders that it was the defendant whose narrative was faulty or misleading. In addition, these defendants were taking a risky move in not denying the wrong outright in their defenses; this could come back to haunt them if the jury did not side with them on the first point of contention. If a jury sided with the plaintiff, the case and all its pleading history would have been back before the Court of

\footnotetext{
${ }^{127}$ From the sample of guides to pleadings created for personnel of the court in the seventeenth century that I consulted I could not find any guidelines for the amount of damages litigants could request for particular offenses. Indeed, examining these cases there is no standard amount say for a man attacked by one other man or a man attacked by two men. Even in cases which seem on the surface to be the same, damages requested vary. Two examples of these guides are George Townesend, A Preparative to Pleading Being a Work intended for the Instruction and Help of Young Clerks of the Court of Common Pleas (London: Israel Harrison, 1675); R.A., Placita Latine Rediviva: A Book of Entries; Containing Perfect and Approved Precedents of Counts, Declarations, Barrs, Avowries, Replications, Pleas in Abatement, Issues, Judgments, As well as Actions Real as Personal, And Sundry other Entries; useful for all Clerks, Attorneys, and Practicers in the Courts at Westminster, and inferiour Courts (London: H. Layford, John Place, and T. Passet, 1673).

${ }^{128}$ In two cases, the plaintiffs defaulted. TNA, CP 40/602, rot. 116d; TNA, CP 40/611, rot. 124. In a third case, the plaintiff was awarded damages of one shilling and one pence; however, there was no indication that it was paid. TNA, CP 40/617, rot. 179.
} 
Common Pleas in order for the defendant to enter a new plea; ${ }^{129}$ any new narrative in the new plea would need to take into account the tacit admission of committing the wrong in order to be believable.

Other than the category of pleading a special issue, it may seem like there is not a lot that links these cases. There seems to be no rhyme or reason to the damages requested. The lowest amount of damages requested was ten pounds and five cases have damages at this relatively low amount. ${ }^{130}$ Three plaintiffs request twenty marks in damages. The most common amounts requested were twenty pounds, at seven cases and forty pounds, at fourteen cases. The next highest cases saw the plaintiff request forty marks and another plaintiff request sixty pounds. In six of the cases, the plaintiffs requested one hundred marks and in five, they requested one hundred pounds, these were large sums of money for the fifteenth century. However, by far, the most amount in damages requested was 1,000 marks, again, there was no explanation given within the plea rolls of the Court of Common Pleas as to why this theft case warranted so much in damages. Certainly to modern sensibilities Wyse's ordeal sounds much worse on paper than Standelf, the Niandeseres, or Nyweport. But we are missing some information in those cases. We do not know the occupations of the plaintiffs; in some we do not even know the occupation of the defendants. It could be that Nyweport had a lucrative business that was severely damaged as a result of the trespass, and 1,000 marks to him was just a fraction of what he had lost; or it could

\footnotetext{
${ }^{129}$ Neither party could change any plea that had been duly recorded onto the plea rolls of the Court of Common Pleas. As a delaying tactic, this could prove riskier than skipping a session of court (a more common tactic). All the previous pleadings would still be on record and any future pleadings would need to consider facts submitted earlier in the case.

${ }^{130}$ Ten pounds was quite a sum of money in the early fifteenth century. This was equivalent, roughly, to two years' worth of wages for a skilled tradesman. While there was a law that the Court of Common Pleas would not hear cases concerning property valued at less than forty shillings, there did not seem to be a lower limit on damages requested in other types of suits. See chapter two for more information on this. For all the cases I looked at for this dissertation, however, ten marks (six pounds, thirteen shillings, and four pence) was lowest amount of damages requested.
} 
be that he was just greedy. And Wyse (or any of the others who requested it) might see twenty pounds as a hefty sum. That could equal up to five years' worth of rent on a small cottage, so it might not be pocket change to some. ${ }^{131}$ It is important, therefore, to keep in mind relative value and that we have only a glimpse through these narratives. It is clear that the statuses of the defendants and plaintiffs, the economic situations of both, and how injurious the plaintiffs perceived the wrongs done to them to be, all factor into how they came up with the price tag attached to their suit.

For many of these cases, it came down to a situation of "he said, he said", which means winning or losing the case might depend on their carefully crafted narrative, whether plaintiff or defendant, as well as their reputation, in order to lend credibility to their narration of events. While society accepted that some violence by private individuals might be licit, the person that attempted to claim such a thing in a court needed have a good reputation. Some defendants may not have had a reputation that would lend credence to their claims, but their fate was still in the hands of a jury that may or may not have been amenable to their side of the story. Is just saying something was true going to be enough to convince other people of its veracity? Were there witnesses that might help a narrative of arbitration? Did one's reputation uphold the idea selfhelp was acceptable? How can one prove the tort was no longer a wrong? For the cases I have examined in this chapter, these questions remain unanswered, but perhaps both parties kept in mind the difficulties of navigating the legal systems and the usefulness of a carefully crafted narrative in pursuing their aims before the court.

${ }^{131}$ See lists compiled at "Medieval Price List" by Kenneth Hodges, http://medieval.ucdavis.edu/120D/Money.html. 


\section{Map 2 - Parishes and Wards in London, 1405-1415}

This map shows the parishes as identified as sites of violence in the eighty-two cases used in this dissertation. Included are the wards of London, the wall surrounding London, some major and minor roads, as well as Westminster Hall.

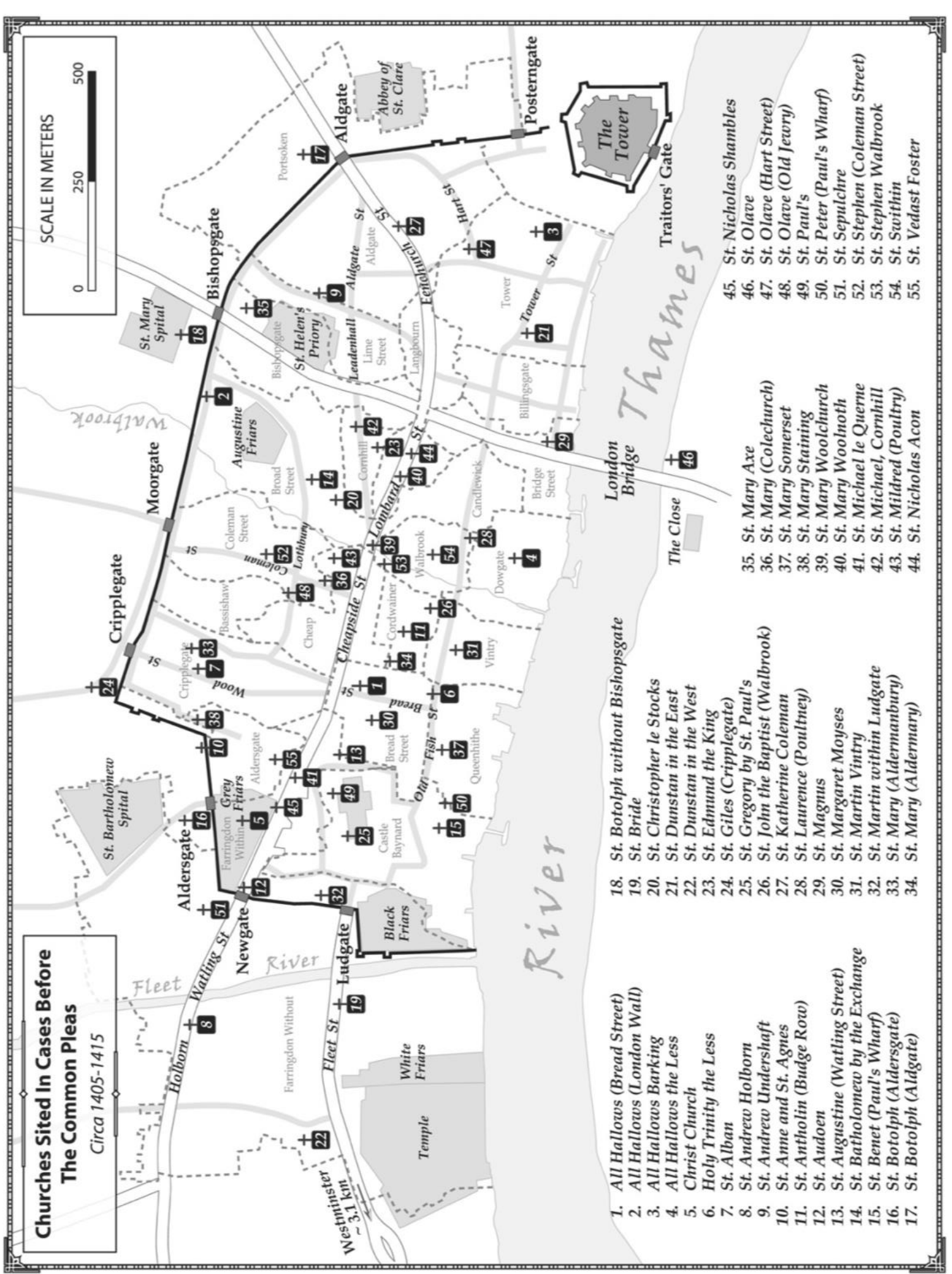

$\stackrel{2}{\ddagger}$ ह $\dot{3}$ is $\tilde{E}$ ๑ $\varangle$ สิ $\rightarrow \infty$ $\rightarrow \frac{0}{0}$ รำ Iิ 을 ई

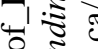
ㄴ. 离 空 .ত্ 象 苂芯 으율 을 ㅇํㅇำำ 띵 छ ㅎํ웣 ส

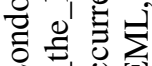
世

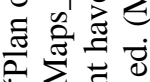

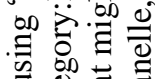
๑ $\triangleq \bigcup$ $z$ 章

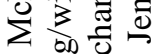

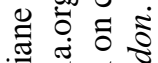

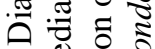
즈큐 독 武 जै है 킬ㄹㄹ 告总总 


\section{Chapter 4 - In Fear for their Lives: Assault and Self-Defense}

\section{Introduction}

William Westwode sued John Barton for theft and assault and requested 100 pounds in damages; the case initially came before the Court of Common Pleas during the 1405 Michaelmas law term. ${ }^{1}$ According to the suit, Barton allegedly attacked John Brampton, Westwode's servant, and absconded with forty pounds in cash. Barton came before the court and denied all wrongs and the sheriff was ordered to impanel a jury, unless the case was heard at the next assize session first. As it happens, Justice William Hankeford and Associate Justice John Coffyn presided over the trial of the case on February 18, 1406 at the assize at St. Martin le Grand. The jury, duly impaneled, reported that Barton had stolen from Westwode, but only ten pounds. Furthermore, they decided that Barton had not assaulted Westwode's servant. For this case, then, the court not only assessed thirteen pounds in damages to be paid to Westwode, but also put him in mercy for falsely accusing Barton of assault. ${ }^{2}$

While Westwode v. Barton does come to a conclusion, even those cases that did not can illustrate how medieval Londoners might have experienced violence; that is, if one does not assume trespass vi et armis cases were legal fictions. Philippa Maddern suggests that the gentry often used lawsuits to harass opponents during land disputes. In addition, she says that the violence in some of the cases she discusses was probably the result of those same land disputes. ${ }^{3}$ It is possible that the Londoners present before the Court of Common Pleas, likewise used legal means to intimidate political or personal opponents. As discussed in the previous chapter,

\footnotetext{
1 The National Archives, CP 40/579, rot. 160; hereafter, TNA.

${ }^{2}$ Mercy in this sense meant that Westwode owed a fine, paid to the crown, for the false accusation.

${ }^{3}$ Philippa C. Maddern, Violence and Social Order: East Anglia 1422-1442 (Oxford: Oxford University Press, 1992), 47.
} 
litigants were knowledgeable of their options and could manipulate the courts in pursuit of their own needs. In addition, the procedures for pursuing an instance of assault before the Court of Common Pleas were distinct from misdemeanor or felony procedures and defendants had greater capabilities to defend against the accusations in the Court of Common Pleas. Clearly, the jury felt Westwode had lied about the assault against his servant, but his motivations for having done so do not make it into the records. However, it was not beyond the realm of possibility that a person could be assaulted and robbed in the street while going about their business. Assault cases before the Court of Common Pleas illustrate a major difference in defense pleas between civil and criminal procedures. However, they also give insight into the circumstances in which physical violence might have believably occurred as well as the negotiations between litigants and the crown over licit and illicit violence.

There are three ways in which a plaintiff might falsify, all or parts of, a wrong in order to get a case before a central court. First, the plaintiff could falsify where the wrong took place in order to speed up the process of justice; this was how the Bill of Middlesex came about, which was discussed in chapter one. Second, the plaintiff could lie about the level of the wrong. For instance, they could accuse a defendant of a felony theft rather than misdemeanor theft by falsely increasing the amount or cost of the stolen goods. ${ }^{4}$ And finally, the plaintiff could claim that a non-violent wrongful act broke the king's peace through the use of weapons, which was called $v i$ et armis. By tacking on the language of both vi et armis and breaking the king's peace (contra paces regis), a non-violent wrong would increase from misdemeanor to felony status for a criminal procedure and come under the action of trespass vi et armis for civil procedures. It

\footnotetext{
${ }^{4}$ In modern parlance, these would equate to grand larceny and petty theft. While terminology may have changed, the concepts did not, one earned a harsher punishment than the other. In the fifteenth century, hanging was the punishment for a person convicted of a felonious theft, or any felony.
} 
differs from merely increasing the cost, as in the second example, because in alleging the perpetrator used violence and broke the king's peace it became an issue of public order rather than a private conflict. Using this language for a trespass meant the case went from a local jurisdiction to a royal one, either the Court of the King's Bench or the Court of Common Pleas. ${ }^{5}$

Historians who examine violence and the law have a tendency to dismiss trespass vi et armis cases because of the assumption that they were legal fictions. ${ }^{6}$ These scholars each focus on various aspects, such as plaintiffs using vi et armis to move a non-violent wrong into a court with a royally appointed judge; Warren Brown, Richard Kaeuper, and Penny Tucker have all interpreted trespass vi et armis in this vein. ${ }^{7}$ Others, such as Maddern, M. W. McHaffie, and Janet Loengard, argue these cases were only brought before the court to advance disputes about other matters, usually land disputes. ${ }^{8}$ It seems reasonable to assume that some people lied in the cases analyzed in this dissertation: about the violence, the nature of the wrong, or the wrongful act itself.

If one thinks of violence only in terms of physical violence against a person, many of the torts classified under this action would not necessarily qualify as violent. In modern times, housebreaking does not have to be violent, neither does theft of goods. There is no physical violence inherent in those acts. Disseisin could be violent, but was not necessarily so; the same could be said for abduction or imprisonment. ${ }^{9}$ There is definitely the place for violence in any of

\footnotetext{
${ }^{5}$ Warren C Brown, Violence in Medieval Europe (Harlow, UK: Pearson Education Limited, 2011), 207.

${ }^{6}$ This historiography was discussed in more detail in chapter one.

${ }^{7}$ Brown, Violence in Medieval Europe; Richard Kaeuper, Chivalry and Violence in Medieval Europe (Oxford: Oxford University Press, 1999); Penny Tucker, Law Courts and Lawyers in the City of London 1300-1550 (Cambridge Studies in English Legal History) (Cambridge: Cambridge University Press, 2007).

${ }^{8}$ Janet Loengard, "What is a Nice (Thirteenth-Century) English Woman Doing in the King's Courts?," in The Ties that Bind: Essays in Medieval British History in Honor of Barbara Hanawalt, ed. Linda E. Mitchell, Katherine L. French, and Douglas L. Biggs (Farnham, UK: Ashgate Publishing, 2011); Maddern, Violence and Social Order; M. W. McHaffie, "Law and Violence in Eleventh-Century France," Past \& Present 238, no. 1 (2018).

${ }^{9}$ Disseisin meant someone had illegally seized non-moveable personal property, i.e. land.
} 
these acts, and while it is not clear how medieval Londoners felt about these legal classifications, each was defined by medieval law as a violent act. However, as Maddern shows, "suing out a writ of trespass vi et armis was the commonest means of bringing a case to law." 10 Therefore, it is logical to look at this writ on its own merit, to examine what it can tell the historian about how people conceptualized and possibly experienced violence. In this way, we can also uncover facets of negotiation over licit and illicit violence, both between the courts and litigants, but also among the savvy litigants themselves. This chapter examines thirty-two trespass vi et armis cases where at least one of the wrongful acts was an assault and of which nineteen defendants pleaded a special issue. In ten of these cases, defendants structured their narrative around social mores that certain types of violence were acceptable. Those defendants employed a narrative that argued that defending oneself or others was a licit use of violence and therefore they were not guilty of assault.

Today, we would most easily understand the action described in these cases as assault. The cases in the Court of Common Pleas, however, did not use the word assault in English nor was assault a distinct legal category in criminal procedures. ${ }^{11}$ Instead, one would have taken an alleged assailant to court over an injury, which might have been the result of a fight, but not for the assault itself. Assault, in and of itself, is violent. In the first definition for assault, as a modern verb, in the Oxford English Dictionary it states: "To make a violent hostile attack by physical means upon (a person, army, etc.); to commit an unlawful or criminal assault upon the person of." 12 The same holds true for assault as a noun: "An onset or rush upon any one with hostile

\footnotetext{
${ }^{10}$ Maddern, Violence and Social Order, 89.

11 According to the Middle English Dictionary, the word assault was not used in a legal sense, in English, for the first time until around 1475. But it seems to have been in use before this with similar definitions. "asaut and assaut, n.," Middle English Dictionary at the Medieval English Compendium, 2018, https://quod.lib.umich.edu/m/middleenglish-dictionary/dictionary/MED2555 (accessed 3/24/2019).

12 “assault, v.," OED Online, 2018, Oxford University Press, http://www.oed.com/view/Entry/11747 (accessed January 17, 2019). Hereafter, referred to as OED.
} 
intent; an attack with blows or weapons." ${ }^{13}$ Violence is in the definition of assault. By this reasoning, assault cases were never vi et armis legal fictions because they were, by definition, a forcefully violent act, one that already belonged in a central court.

Translating the information about the tort for trespass vi et armis cases concerning assault demonstrates that it (assault) was an inherently violent act, especially as it was used in these cases. The cases use the phrase insultum fecit, usually followed by verberavit, vulneravit, et male tractavit. ${ }^{14}$ Insult/us means assault or attack. ${ }^{15}$ Fecit/fecerunt are the singular and plural perfect active forms of facio/facere, which means to make. The full phrase translates as 'to make an assault'. Verberavit/verberaverunt are the singular and plural perfect active forms of verbero/verberare, which means to beat. Vulneravit/vulneraverunt are the singular and plural perfect active forms of vulnero/vulnerare, which means to wound. Tractavit/tractaverunt are the singular and plural perfect active forms of tracto/tractare, which could mean to maul, but in the context of the full sentence probably means to treat. And, male as an adverb means badly. ${ }^{16}$ This clause, added to the 'make an assault' phrase, provides more details in that alleged victim was also beaten, wounded, and ill-treated. One cannot assault someone else without perpetrating violence. This discussion of language does not prove that violence happened in these cases. Rather, these cases are useful in illustrating believable stories of violent experiences (whether true or not), which furthers our understanding of how medieval people conceptualized licit and illicit violence.

13 “assault, n.," OED Online, 2018, Oxford University Press, http://www.oed.com/view/Entry/11746 (accessed January 17, 2019).

14 These are the singular versions, but when there were multiple assailants, these words would be insultum fecerunt, and verberaverunt, vulneraverunt, et male tractaverunt.

15 R. E. Latham, Revised Medieval Latin Word-List from British and Irish Sources (Oxford: Oxford University Press, 1965), 254. Latham cites this meaning as early as 1190. I have used Latham in this instance because the definition does change between classical Latin usage and Medieval Latin.

${ }^{16}$ All definitions were found in Harper Collins Latin Concise Dictionary. 
Only thirty-two cases included assault (insultum fecit) out of the eighty-two cases of trespass vi et armis between 1405 and 1415 in which the defendants entered a plea. Of these thirty-two cases, thirteen involved multiple torts (including the language of assault) and nineteen involved only assault. Some of these cases fall under a fictionalization category in that it might have been a false accusation, that the assault did not occur, or perhaps there was a different dispute between the litigants. However, in order to uncover what any of these thirty-two cases can illustrate about violence, we must first delve into concepts of violence at work in the fifteenth century. In the first section of the chapter, I examine conceptualizations of licit and illicit violence. While these records do use formulaic language, that language can illustrate how people might have experienced violence, even if the pleas were not in their own words. In the next section, I analyze the variations between criminal and civil procedures, especially in relation to pleading self-defense. A non-fatal attack could be pursued as a misdemeanor or trespass action, although the regulations on defenses differed between criminal and civil procedures. Only in homicide, which was a felony, could a defendant claim they acted in self-defense.

Table 3 - Cases With Assault Broken Down by Tort Category

\begin{tabular}{l|l}
$\begin{array}{l}\text { Cases with } \\
\text { Assault }\end{array}$ & $\begin{array}{l}\text { Number } \\
\text { of Cases }\end{array}$ \\
\hline Assault & 19 \\
\hline $\begin{array}{l}\text { Assault, } \\
\text { Abduction, } \\
\text { Taking of } \\
\text { Goods }\end{array}$ & 1 \\
\hline $\begin{array}{l}\text { Assault, } \\
\text { Housebreaking, } \\
\text { Taking of } \\
\text { Goods }\end{array}$ & 3 \\
\hline $\begin{array}{l}\text { Assault, } \\
\text { Imprisonment }\end{array}$ & 5 \\
\hline $\begin{array}{l}\text { Assault, Taking } \\
\text { of Goods }\end{array}$ & 4 \\
\hline
\end{tabular}


In the last section of the chapter, I explore nine cases in which defendants in trespass vi et armis actions claimed that they acted in self-defense for a non-fatal physical altercation. Those defendants attempted to legitimize their violence through "confession and avoidance", a plea in which the defendant contested some point of the plaintiff's count. ${ }^{17}$ For the defendants who used a "confession and avoidance" plea to justify their actions, it meant they explicitly admitted to the assault. In sixteen of the thirty-two cases, the defendants admitted to the accusations; the litigants did indeed have a violent altercation with one another. Therefore, in fifty percent of the cases discussed in this chapter, violence had occurred. While all trespass vi et armis actions pertain to violence, as conceptualized by medieval English law, narratives contained in assault allegations demonstrate not only a major difference between criminal and civil procedures, but also illustrate societal negotiations over what constituted licit and illicit violence. In the early fifteenth-century criminal procedures, the legal system narrowly defined how a defendant could gain a pardon for acting in self-defense, as witnessed in appeals for homicide. In contrast, society seemed to allow for a more relaxed view of the circumstances under which a defendant could plead self-defense, as seen in the trespass vi et armis cases before the Court of Common Pleas

\section{Licit and Illicit Violence}

In the late Middle Ages, violent acts were visible to people in many different scenarios. This violence could take the form of a war, whether perpetrated by a local or central polity, state violence as used in judicial punishments, or the various types of interpersonal violence: robbery, beatings, fighting, and feuding. How this violence was interpreted and to what extent it was accepted (or rejected) by a society depended on both time and place. Violence in an urban setting

\footnotetext{
${ }^{17}$ I discuss the four types of pleas in more detail in chapter two, but briefly, "confession and avoidance" means a defendant admits to the alleged act, but offers an explanation over why their actions were not illicit. A jury would then be impaneled to render a verdict only on that issue.
} 
held different connotations from that in the countryside. Violent urban uprisings mostly contested the boundaries placed on them by people in power; many of them were merely staged riots, theatrically expressing their displeasure. ${ }^{18}$ Over time, large-scale interpersonal violence came to threaten the central governments of medieval Europe. ${ }^{19}$

The licitness of small-scale interpersonal violence, on the other hand, continued to be negotiated among individuals. Both Hannah Skoda and Warren Brown argue that violence was communicative, but first one needed to understand the shared norms of a particular society at a particular time. ${ }^{20}$ Interpersonal violence shared information on several levels. First, it conveyed to the parties involved directly with the violence that there was a dispute. Often, the parties knew there was a problem between them before it escalated to violence, but not always. ${ }^{21}$ Second, it transmitted a message to all those who witnessed the violence. The composition and import of the message depended on where the violence occurred and who it was between. Different groups within a society would have had different understandings of violence. ${ }^{22}$ Going to court and the laws themselves were two ways to be socialized in the norms of violence. Legal procedure was performative and needed to be performed in order to be understood. It was in the courts and the cases before them that many medieval people were educated as to what counted as an acceptable use of violence. By studying the court records historians can discover what norms were

\footnotetext{
${ }^{18}$ See, for example, chapter five in Hannah Skoda, Medieval Violence: Physical Brutality in Northern France, 1270 1330 (Oxford: Oxford University Press, 2013), 159-92.

${ }^{19}$ For an example of this, albeit later in the fifteenth century, see Robin Jeffs, "The Poynings-Percy Dispute: An Example of the Interplay of Open Strife and Legal Action in the Fifteenth Century," Historical Research 34, no. 90 (1961).

${ }^{20}$ Skoda, Medieval Violence, 18; Brown, Violence in Medieval Europe, 138.

21 The latter would certainly be true for some of the litigants that Maddern discusses who used violence as a part of a larger dispute between them.

22 Skoda, Medieval Violence, 48. Almost any history of violence in the Middle Ages addresses the variations in acceptable violence among the status systems of Europe. However, for good starting points for status and violence, see: Brown, Violence in Medieval Europe; Kaeuper, Chivalry and Violence in Medieval Europe. Shannon McSheffrey highlights the tension between ideals of aristocratic masculinity and the requirements of the self-defense narrative in felony cases: Shannon McSheffrey, "The Slaying of Sir William Pennington: Legal Narrative and the Late Medieval English Archive,” Florilegium 28 (2011).
} 
applicable at a given point in time.

We can break violence down into two categories: licit or illicit. It would have been the norms a person was socialized in that helped them categorize the various types of violence they might witness, take part in, or be a victim of over their lifespan. This socialization depended on gender, status, location (both in the sense of urban or rural environment, but also where in Europe they were), and in what time period they lived. Violence that was acceptable by both society and the laws in Anglo-Saxon England would not be the same as that in Elizabethan England. In some instances, the laws and society do not agree on the legitimacy of violence. For example, long before the laws of England distinguished between murder and manslaughter, the juries of England did so. ${ }^{23}$ In terms of gender, many historians have pointed out that society may have socialized women to be less violent, but that does not necessarily mean they were; it usually meant their violence was considered unacceptable or illicit. ${ }^{24}$ It also means that violence perpetrated by women was often viewed in a different way than that committed by men. ${ }^{25}$ Skoda devoted an entire chapter to the legitimacy of domestic violence within certain parameters, parameters decided upon by mostly ecclesiastical figures. ${ }^{26}$ For these two examples, violence against women and violence perpetrated by women, what defines the difference between licit and illicit is the threat to the social order of society at large, according to Skoda. Even something as interpersonal and, in the modern view, private, as domestic violence, held larger societal implications.

\footnotetext{
23 Thomas A. Green, "Societal Concepts of Criminal Liability for Homicide in Mediaeval England," Speculum 47, no. 4 (1972), 669.

${ }^{24}$ See the historiography on law and gender in chapter one, including Krista J Kesselring, "Bodies of Evidence: Sex and Murder (or Gender and Homicide) in Early Modern England, c. 1500-1680," Gender \& History 27, no. 2 (2015), 252; Garthine Walker, Crime, Gender and Social Order in Early Modern England (Cambridge: Cambridge University Press, 2003), 75-77.

${ }^{25}$ Kesselring, "Bodies of Evidence," 253.

${ }^{26}$ Skoda, Medieval Violence, 193-231.
} 
Different statuses of people also had different claims to licit and illicit violence. Men of knightly or noble status could use 'defense of honor' as a legitimate social, although not legal, excuse for violence. ${ }^{27}$ This also harkens to the issue of visibility: defending one's honor had to be done in a way in which people knew it had been done, otherwise, the slight would stand uncorrected in the eyes of society. Men and women of the lower statuses were no less concerned with reputation, but the legitimate avenues of using violence available to them were significantly fewer. The majority of litigants in my cases were somewhere between titled nobility and the lower economic statuses. Only a few were listed as gentleman, however most of them belonged to the upper echelons of urban society based on their occupations listed in the records of the Court of Common Pleas. It is unclear whether they would have been classified as gentry, a rural designation. Given the more limited availability to legitimately use violence by the urban elite, it is perhaps not surprising that so many took to the courts to restore reputation after an act of violence rather than responding with violence in kind. Legitimate use of violence, then, depended upon time, place, and social status, and, crucially, was culturally constructed.

While this chapter focuses on assault, in thirteen of the thirty-two trespass actions the plaintiffs accused the defendants of multiple wrongs. All thirteen of these cases included assault, five also included imprisonment, three included theft, and one included abduction. Three cases included both theft and housebreaking, and only one case included abduction and theft. In eight of the cases, the defendants denied the charges, whether that was through a general issue of a "not guilty" plea or sometimes through a special issue. These thirteen cases are where the uncertainty of the claims of violence are the highest. However, it seems unlikely that the

\footnotetext{
${ }^{27}$ For more on this, see Brown, Violence in Medieval Europe, 262-66; Kaeuper, Chivalry and Violence in Medieval Europe, 7-8; McSheffrey, "The Slaying of Sir William Pennington," 185-86.
} 
plaintiffs needed to accuse the defendant of assault in order to enhance the charges. ${ }^{28}$ Three defendants pleaded special issues, whereby they denied the assault and made claims concerning the other wrongs. Only three of the cases came to a conclusion, two as a result of the plaintiff defaulting, which was not the same as an acquittal. More than likely, the parties had come to an agreement outside of court and as part of that agreement, the plaintiff stopped pursuing the case in court. ${ }^{29}$ Of course, any of the plaintiffs could have falsely accused the defendant, although it is an unlikely assertion for four of the cases. Rather than denying the accusations, four defendants pleaded special issues that argued the case should be thrown out; in these special pleadings, defendants tacitly admitted to the wrongs. ${ }^{30}$ These cases are the most certain when it comes to knowing that actual violence occurred. However, even with the possibility of multiple layers of falsehoods, the cases can still illustrate medieval notions of violence, licit or illicit.

In Westwode v. Barton, for example, in which Westwode accused Barton of both abduction and assault and Barton denied all accusations, Westwode's account of his servant being assaulted and Barton stealing forty pounds was a believable act of violence. However, according to the jury, it was not what actually happened. In terms of the alleged assault, Barton was vindicated as the jury concluded that he had not attacked Brampton (Westwode's servant). However, the jury decided Barton was guilty of stealing ten pounds, a much smaller sum than alleged. Westwode was awarded thirteen shillings in damages, but then had to pay a fine to the king for falsely accusing Barton of the assault. ${ }^{31}$ If, as the events related by Westwode suggest, the assault happened during the theft (in modern parlance a strong-arm robbery), then the jury's

\footnotetext{
28 Thirty-six other cases in my sample included theft, twenty-two included abduction, ten included housebreaking, one included imprisonment, and one involved disseisin; all of these were either on their own or with other wrongs, but did not include assault. These are much more likely to have used the legal fiction of trespass vi et armis than the ones that included assault.

${ }^{29}$ Maddern, Violence and Social Order, 42.

${ }^{30}$ In cases where the defendants used the concept of self-defense, it was an explicit admission.

31 The amount of the fine for the false accusation was not specified in the records.
} 
verdict indicates that while the theft was wrong, any violence done during its commission was not severe enough to warrant censure.

Table 4 - Details for Thirteen Cases with Multiple Torts

\begin{tabular}{|c|c|c|c|c|c|c|c|}
\hline Case Name & Term, Year & Torts & Date & Damages & Pleading & Concluded & TNA Reference \\
\hline Bremore v. Rose & Michaelmas, 1413 & $\begin{array}{l}\text { Assault } \\
\text { Taking of Goods }\end{array}$ & $3 / 21 / 1412$ & $£ 60$ & $\begin{array}{l}\text { Not } \\
\text { Guilty }\end{array}$ & No & CP 40/611, rot. 457 \\
\hline $\begin{array}{l}\text { Cheseman v. } \\
\text { Treweman }\end{array}$ & Michaelmas, 1415 & $\begin{array}{l}\text { Assault } \\
\text { Housebreaking } \\
\text { Taking of Goods }\end{array}$ & $8 / 6 / 1415$ & $£ 10$ & $\begin{array}{l}\text { Not } \\
\text { Guilty }\end{array}$ & No & CP 40/619, rot. $179 \mathrm{~d}$ \\
\hline Creyk v. Capon & Michaelmas, 1405 & $\begin{array}{l}\text { Assault } \\
\text { Housebreaking } \\
\text { Taking of Goods } \\
\end{array}$ & $9 / 17 / 1405$ & $£ 20$ & $\begin{array}{l}\text { Special } \\
\text { Issue }\end{array}$ & No & CP 40/579, rot. 552 \\
\hline $\begin{array}{l}\text { Gerland v. } \\
\text { Dripol }\end{array}$ & Easter, 1415 & $\begin{array}{l}\text { Assault } \\
\text { Housebreaking } \\
\text { Taking of Goods }\end{array}$ & $5 / 29 / 1413$ & $£ 6613 \mathrm{~s} 4 \mathrm{~d}$ & $\begin{array}{l}\text { Special } \\
\text { Issue }\end{array}$ & Yes & CP 40/617, rot. 179 \\
\hline $\begin{array}{l}\text { Iklyngton } v . \\
\text { Kyngeston }\end{array}$ & Michaelmas, 1412 & $\begin{array}{l}\text { Assault } \\
\text { Taking of Goods }\end{array}$ & $11 / 14 / 1404$ & $£ 100$ & $\begin{array}{l}\text { Special } \\
\text { Issue }\end{array}$ & No & CP 40/607, rot. 380d \\
\hline $\begin{array}{l}\text { Power v. atte } \\
\text { Chirche }\end{array}$ & Trinity, 1411 & $\begin{array}{l}\text { Assault } \\
\text { Abduction } \\
\text { Taking of Goods } \\
\end{array}$ & $4 / 22 / 1408$ & $£ 40$ & $\begin{array}{l}\text { Special } \\
\text { Issue }\end{array}$ & Yes & $\mathrm{CP} 40 / 602$, rot. $116 \mathrm{~d}$ \\
\hline Pytard v. Fissher & Trinity, 1410 & $\begin{array}{l}\text { Assault } \\
\text { Taking of Goods }\end{array}$ & $5 / 23 / 1410$ & $£ 2613 \mathrm{~s} 4 \mathrm{~d}$ & $\begin{array}{l}\text { Not } \\
\text { Guilty }\end{array}$ & No & CP 40/598, rot. 475 \\
\hline $\begin{array}{l}\text { Rynfeld } v . \\
\text { Shyftling }\end{array}$ & Easter, 1410 & $\begin{array}{l}\text { Assault } \\
\text { Imprisonment }\end{array}$ & $6 / 29 / 1395$ & $£ 6613 \mathrm{~s} 4 \mathrm{~d}$ & $\begin{array}{l}\text { Not } \\
\text { Guilty }\end{array}$ & No & CP 40/597, rot. 128 \\
\hline Spenser v. Dyns & Michaelmas, 1415 & $\begin{array}{l}\text { Assault } \\
\text { Imprisonment }\end{array}$ & $6 / 1 / 1415$ & $£ 40$ & $\begin{array}{l}\text { Special } \\
\text { Issue }\end{array}$ & No & CP 40/619, rot. 597d \\
\hline $\begin{array}{l}\text { Swepston v. } \\
\text { Bargon }\end{array}$ & Trinity, 1411 & $\begin{array}{l}\text { Assault } \\
\text { Imprisonment }\end{array}$ & $4 / 4 / 1411$ & $£ 40$ & $\begin{array}{l}\text { Special } \\
\text { Issue }\end{array}$ & No & CP 40/602, rot. $171 d$ \\
\hline Swyft v. Pope & Trinity, 1410 & $\begin{array}{l}\text { Assault } \\
\text { Imprisonment }\end{array}$ & $4 / 23 / 1408$ & $£ 136 \mathrm{~s} 8 \mathrm{~d}$ & $\begin{array}{l}\text { Not } \\
\text { Guilty }\end{array}$ & No & CP 40/598, rot. 345 \\
\hline $\begin{array}{l}\text { Westwode v. } \\
\text { Barton }\end{array}$ & Michaelmas, 1405 & $\begin{array}{l}\text { Assault } \\
\text { Taking of Goods }\end{array}$ & $6 / 15 / 1405$ & $£ 100$ & $\begin{array}{l}\text { Not } \\
\text { Guilty }\end{array}$ & Yes & CP 40/579, rot. 160 \\
\hline $\begin{array}{l}\text { Wyse v. } \\
\text { Whitehed }\end{array}$ & Michaelmas, 1415 & $\begin{array}{l}\text { Assault } \\
\text { Imprisonment }\end{array}$ & $6 / 23 / 1415$ & $£ 20$ & $\begin{array}{l}\text { Special } \\
\text { Issue }\end{array}$ & No & CP 40/619, rot. 359 \\
\hline
\end{tabular}

*In this table, I have outlined the cases from this section of chapter four. Defendants could enter four types of pleadings, those pleading "not guilty" entered a general issue. Those who disputed a point in the plaintiffs count, entered a special issue plea.

When a defendant pleaded a special issue, either tacitly or explicitly admitting to the alleged assault, we get a clearer understanding of the concepts of licit and illicit violence. For two of these cases with special issue pleadings, the defendant claimed the plaintiffs ought not to be able to sue them because they had undergone arbitration to settle their problems. ${ }^{32}$ This

\footnotetext{
${ }^{32}$ TNA, CP 40/610, rot. 112d; TNA, CP 40/608, rot. 305.
} 
arbitration occurred after the altercation, which the defendants admitted to, but before the plaintiff brought the case before the Court of Common Pleas. Clearly, these litigants had a problem with each other, one that escalated to a violent altercation. It does not seem as if these plaintiffs were trying to force arbitration, as Maddern and others have shown to be one of the rationales behind suing because, according to the defendant, they had already undergone arbitration, assuming the defendants were truthful in their pleading. ${ }^{33}$ It could have been, as the plaintiffs often claimed, that the arbitration was over something else (in at least one case, the litigants discussed the rights and titles to a messuage). ${ }^{34}$ Therefore, it is possible that a violent altercation occurred during a larger land or other type of dispute. However, one should not dismiss this instance of violence because it was not violence for violence's sake. That the men who disputed access to a messuage felt no qualms about resorting to violence during a land dispute suggests quite a bit in terms of their views of asserting their rights. It further shows that violent self-help or violent vengeance were hard for rulers to root out. ${ }^{35}$

Using violence to help oneself features, in a small way, in nine cases during this time period, which I discuss in greater detail below. The defenses noted in the records rather implicitly admitted to violence in that the defendants all claimed they were defending themselves from an attack by the plaintiff. ${ }^{36}$ While any of these cases could have been a simple dispute over merchandise, pricing, or other business agreements that escalated into violence, what I am interested in is that they escalated to violence. In using an assertion that they were defending

\footnotetext{
33 These cases and litigant motivations were discussed in more detail in chapter three.

${ }^{34}$ A messuage was a home which usually also came with land and outbuildings. "messuage, n," OED Online, 2018, Oxford University Press, http://www.oed.com/view/Entry/117128 (accessed February 10, 2019). TNA, CP 40/608, rot. 305 .

${ }^{35}$ Brown, Violence in Medieval Europe, 213, 293.

36 TNA, CP 40/594, rot. 135; TNA, CP 40/603, rot. 502; TNA, CP 40/604, rot. 111d; TNA, CP 40/582, rot. 412d; TNA, CP 40/577, rot. 199; TNA, CP 40/619, rot. 359; TNA, CP 40/576, rot. 250; TNA, CP 40/603, rot. 566; TNA, CP 40/611, rot. 457.
} 
themselves, these defendants went on to explain that if the plaintiff was injured as a result of the altercation, then it was their (the plaintiff's) own fault because they started the fight. For example, in the Spore v. Smyth case, John Ludby claimed "that if some harm happened to the same William Spore it was due to his own assault and in defense of the same John Ludby."37 One could presume that the plaintiffs were injured, which was why they sued the defendants in the first place. While whether they fought or not is not a main theme of this dissertation, in these cases at least this was not necessarily violence for show. ${ }^{38}$ However, as discussed earlier in this chapter, there was no indication in the records as to what kind of wounds or injuries the plaintiffs may have sustained. This is one of the major differences between criminal and civil procedures and may be what gave rise to the myth that all trespass vi et armis cases were fictitious. These defendants saw their use of violence in defense of themselves as a licit, rather than illicit, use of violence. They were also leaving it up to a jury to decide, which means they thought there was a possibility the members of the jury would agree with them on their definition of licit violence. In part, the possibility that a jury might agree with the defendant rather than the letter of the law may have rested within the ongoing negotiation between central authority and subjects about what constituted licit and illicit violence. While Brown focused more on the twelfth century, his interpretation of medieval violence remains valid: "It could rather be good or bad depending on who was using it against whom and for what purpose." ${ }^{39}$ His work examines the non-linear path towards a state monopoly on licit violence. ${ }^{40}$ Brown traces the origin of medieval

\footnotetext{
37 TNA, CP 40/577, rot. 199. In Latin it reads like this in the records: "et sic dicit quod malum eidem Willelmus Spore adtunc ibidem enevit hoc fuit de insultum suo propo et in defensionem ipsius Johannis Ludby."

${ }^{38}$ Maddern, McSheffrey, Brown, and Kaueper all speak of this idea of symbolic violence; violence more threatened than fact which could be used to restore honor for someone who was defamed. Brown, Violence in Medieval Europe, 136-38; Kaeuper, Chivalry and Violence in Medieval Europe, 129-31; Maddern, Violence and Social Order, 47; McSheffrey, "The Slaying of Sir William Pennington," 172-73.

${ }^{39}$ Brown, Violence in Medieval Europe, 2.

${ }^{40}$ Clearly people can be and are still violent outside of the bounds of what is allowed by the state. Concepts such as self-defense are also still employed as defenses in modern trials, proving that the state does not have a full monopoly
} 
kings attempting to define and control legitimate violence to the influence of Anglo-Saxon kings of England and also Charlemagne's example on the continent. ${ }^{41}$ Over the centuries between Charlemagne (r. 768-814) and Henry IV (r. 1399-1413) of England, this idea was not without contestation. People throughout medieval Europe refused to quietly give up their own brand of self-help violence. In England, one can see this evolution by examining the changing law codes. Successive kings established rules governing when and how violent vengeance could occur and starting with Henry I (r. 1100-35) the legitimacy of a king rested with his ability to keep the peace in his kingdom. ${ }^{42}$ If violence was, as Maddern states, necessary for public order, who was responsible for perpetrating it? Based on the cases in front of the Court of Common Pleas, by the fifteenth century, it was mostly the purview of the central authority. Kings and lawmakers did this through a series of laws which established the concepts of felonies, misdemeanors, and trespasses. However, the people of England refused to give up all claims to violent self-help as a right protected under common law, as is evident in a few of the cases before the Court of Common Pleas.

Any claims to self-defense could be classified as violent self-help: the defendants used violence to help themselves stave off an attack on their person. However, two cases are revelatory when it comes to violence and the lingering concepts of violent self-help. In the first of the cases, William Kyngeston accused Walter and John Domegode of assault. ${ }^{43}$ He also listed William Domegode as an accessory to the assault. However, much like the cases discussed before this, Walter and John pleaded a special issue. The Domegodes did not, per se, discuss self-defense because according to their narrative of events they were protecting William

\footnotetext{
on violence.

${ }^{41}$ Brown, Violence in Medieval Europe, 72-75.

42 Brown, Violence in Medieval Europe, 198, 200. I discuss these changes in more detail in chapter one.

43 TNA, CP 40/598, rot. 304d.
} 
Domegode (presumably a relative of theirs) from an attack by Kyngeston. They argued that Kyngeston had no case against them because they were only restoring the peace as was lawful of them. ${ }^{44}$ Admitting to using violence against Kyngeston, the Domegodes drew on centuries of tradition by asserting that that use of violence was acceptable in the eyes of society and the law because it was to restore the king's peace rather than break it. ${ }^{45}$ Society and the government long distinguished between violence that created order from that which created disorder. ${ }^{46}$ The Domegodes claimed that their violence against Kyngeston belonged in the former category and put their faith in a jury to see things the same as they did. It is clear that the Domegodes felt defense of someone else was just as licit a use of violence as that of defending oneself; it is unclear whether a jury would have sided with them, but their claims were at least believable and based on ancient custom.

Ancient custom was also behind John Michell's defense in the second case. ${ }^{47}$ In what appears to be a straight-forward case, John Ros accused Michell of assault. Michell claimed that Ros ought not to be able to sue him because he was only trying to recover the twelve pounds that Ros owed to him. This is clearly a throwback to the idea of private vengeance or violent self-help that both Barbara Hanawalt and William Ian Miller discuss. ${ }^{48}$ Ros took exception to how Michell attempted to recover the debt, although Michell saw nothing wrong with it and was taking the chance on the possibility a jury would have agreed with him. This might also fit with Maddern's

\footnotetext{
${ }^{44}$ In the case record, it reads like this: "et pacem domine Regis perturbasse veneris ad ipsum Willelmus Kyngeston ad ipsum pacificandum et ne ipse aliquod dampnum corporale praefato Willelmus Domegode faceret impediendum prout eis bene licuit." "And the peace of the lord King had been disturbed by the same William Kyngeston and the same was pacified so that any damage to the body of the aforementioned William Domegode was prevented, as was their right." TNA, CP 40/598, rot. 304d.

45 Brown, Violence in Medieval Europe, 244.

${ }^{46}$ I discuss this in more detail in chapter one.

47 TNA, CP 40/616, rot. 247.

${ }^{48}$ Barbara Hanawalt, 'Of Good and Ill Repute': Gender and Social Control in Medieval England (Oxford: Oxford University Press, 1998), 8; William Ian Miller, Eye for an Eye (Cambridge: Cambridge University Press, 2005), 1820 .
} 
assertion that it was less about the violence and more about the larger dispute, but it definitely does not count as a legal fiction as Michell does not deny the violence. ${ }^{49}$ Michell disputed how Ros narrated the events and also asserted that Ros was never in any real danger. However, Michell was clear that he felt any violence done by him in an attempt to recover a debt was a licit use. Legally, meaning by statute and law, Michell was not correct; however, the members of the jury might still have agreed with his notion of violent self-help even while the legal authorities objected.

However, even violence done with the law on one's side, did not necessarily mean the violence went uncontested, which brings us back to the case I opened the dissertation with. During the fall of 1405, Geoffrey Creyk appeared before the court, claiming in his suit against Robert Capon that Capon had not only broken into his home, but also assaulted Creyk, and stole goods from him worth ten pounds. ${ }^{50}$ In addition to the ten pounds, Creyk also asked for twenty pounds in damages. This is the trifecta of cases, housebreaking, assault, theft, the only torts missing are an abduction and imprisonment. While Creyk goes on to list the goods stolen (all fabrics) what is interesting is that Capon pleaded a "confession and avoidance" and explained why Creyk's case against him ought to be dismissed. According to Capon, he was sent to Creyk's address to force the appearance of a woman, Alicia Rothale, before the court of the Bishop of London on charges of fornication and defamation. Apparently, Rothale was accused in the ecclesiastical court of having had sex with a number of men, including a chaplain. Capon further stated that Creyk had let him into the house, that he had not broken in. In his narrative, Capon claimed that he should not be sued because he had been acting on orders from an

\footnotetext{
${ }^{49}$ Maddern, Violence and Social Order, 46-47.

50 TNA, CP 40/579, rot. 552.
} 
unnamed archdeacon. ${ }^{51}$ Creyk's rejoinder said a lot too. He claimed he knew nothing about Rothale and even if Capon had been at his address to find Rothale, that did not negate the rest of the claims. According to Creyk, having been sent to an address to bring a woman to an ecclesiastical court did not mean Capon was also permitted to break in (Creyk reasserted that he had not let Capon in), nor did it mean he should beat up the man living there and steal his things. This case is a prime example of what Maddern discusses in terms of people using violence in an official capacity; because the law allowed violence in the capture, treatment, and pleading of defendants, it was legally allowing private individuals to be violent; although not in a private capacity. ${ }^{52}$ While Capon might have felt he was justified in his use of violence in pursuit of Rothale, Creyk certainly did not see it in the same light. Creyk did not necessarily deny the right of an officer of a court to use violence against the actual person they were after, i.e. licit violence, just that Capon was not allowed to use it against innocent people, which, in other words, equated to illicit violence.

\section{Procedural Differences}

Assault could be tried using either criminal or civil procedures. In the first instance, the accused would be indicted or appealed for a misdemeanor. In the second, the alleged victim would start an action of trespass against the accused. However, I could find no record of using

\footnotetext{
${ }^{51}$ Capon's plea reads as follows in the plea records: “dicit quod die et anno praedictis ipse Robertus fuit sumonitor cuiusdam — archidiaconi episcopi London per quod ipse de mandato ipsius archidiaconi ex licensia ipsius Galfridi clausum et domos praedicta intravit ad sumoniendum quandam Aliter Rothale commorantem ibidem in hospicio ipsius Galfridi eo quod ipsa defamata fuit de fornicatione cum quodam Johanne Breche Capello et aliis diversis hominibus ad comperendum coram praefato archidiacono in curia sua $\wedge^{\wedge}$ milkstrete ${ }^{\wedge}$ de London ad respondendum ibidem de fornicatione et defamatione praedictis." "he says that on that day and year the aforementioned Robert was summoned by a certain ---- archdeacon for the Bishop of London, by means of which he was commanded by the same archdeacon, with the permission of the same Geoffrey he entered the aforementioned close and home to summon a certain Alicia Rothale - remaining in that place, in the lodgings of the same Geoffrey for the fact (assertion?) that she was of ill-repute for having sex (fornicating) with a certain John Breche, chaplain, and other diverse men - to the court of the archdeacon [in Milk Street] London, to answer in that place for the aforementioned sex (fornication, immorality) and defamation." TNA, CP 40/579, rot. 552.

${ }^{52}$ Maddern, Violence and Social Order, 71-72.
} 
self-defense in misdemeanor assault cases in the secondary literature; only in discussions of felony homicide cases was this defense used. For homicides, though, it was more of a verdict of self-defense rather than a plea. To use self-defense in a felony case, the accused had to meet stringent requirements. The narrative crafted in those cases usually followed a strict 'formula' in which the victim instigated the attack which ultimately lead to their death and the killer did everything they could to avoid the conflict until there was no choice but to engage. ${ }^{53}$ These requirements included fleeing their attacker until they (the accused) were cornered with no other option than to defend themselves or die. In addition, they were supposed to use only whatever weapon they happened to find lying around them. ${ }^{54}$ In the majority of these cases, the king would issue a pardon on the grounds that self-defense was a justifiable reason for homicide.

In the previous section, I examined representations of licit and illicit violence as evidenced in several cases before the Court of Common Pleas. While most of those cases included instances of assault, none of the defendants who pleaded something other than "not guilty" used the concept of defending themselves as a rationale for why their violence was licit. This pleading of defending oneself best corresponds to modern concepts of a self-defense plea. And while there was no such thing as a self-defense plea in the Middle Ages, the idea that defending oneself or others was a proper use of violence existed in late medieval London; indeed, five of the assault cases examined for this chapter had defendants who used this notion in their narratives. ${ }^{55}$

\footnotetext{
${ }^{53}$ See Green, "Societal Concepts of Criminal Liability," 673; Maddern, Violence and Social Order, 92. for examples of these narratives. See McSheffrey, "The Slaying of Sir William Pennington," 180. for an example where the narrative slightly differs from this.

${ }^{54}$ Green, "Societal Concepts of Criminal Liability," 669. Others have also discussed these requirements, including Maddern, Violence and Social Order, 92; McSheffrey, "The Slaying of Sir William Pennington," 182, 185-186.

${ }^{55}$ Self-defense as an acceptable use of violence existed across England, and perhaps throughout Europe. However, all the evidence I use comes from London. See Brown, Violence in Medieval Europe, 244; Elizabeth Papp Kamali, "Felonia Felonice Facta: Felony and Intentionality in Medieval England," Criminal Law and Philosophy 9, no. 3 (2015), 409-10.
} 
The ideology at work in the Court of Common Pleas cases was, then, similar to that of the felony cases in that the accused put the blame for the violence onto the alleged victim, yet the legal requirements were not the same. The evolution of manslaughter is inextricably linked to that of murder or homicide, neither of which are easy to separate from the others. For example, Thomas Green explains that 'murder' as a term was used solely for when a homicide had been "perpetrated through stealth, at night or by ambush." 56 All other slayings, according to the legal treatise Glanvill, written between 1187 and 1189, would be considered simple homicide.

However, the somewhat clear distinctions between murder and homicide did not last very long as after the thirteenth century all slayings were considered felonies, and thus capital offenses, although juries continued to take into account concepts such as premeditation and intent when rendering verdicts. ${ }^{57}$ According to J.G. Bellamy, as early as the 1340 s "legal authority recognized as distinct categories of homicide those later referred to in law tracts as planned, cold-blooded killing (murder) and slaying in hot blood (killing in chance medley, manslaughter). ${ }^{58}$ Chance medley, or killing a person in hot blood, indicates a level of culpability on the part of the part of the killer, but with mitigating circumstances, such as reacting in anger or a killing during an impromptu fight.

This definition of manslaughter neatly illustrates the ways in which understanding of violence were culturally constructed. By its very nature, this meant that self-defense or acting in the heat of the moment was not open for women to use. As Krista Kesselring explains in her article, "Bodies of Evidence," the medieval medical knowledge was based on the ideas of Galen

\footnotetext{
${ }^{56}$ Green, "Societal Concepts of Criminal Liability," 672. This conclusion is also echoed by J.G. Bellamy as he shows by the thirteenth century murder was used when the slaying was done by stealth or in a way in which the victim could not defend themselves. J.G. Bellamy, The Criminal Trial in Later Medieval England: Felony Before the Courts From Edward I to the Sixteenth Century (Toronto: University of Toronto Press, 1998), 60.

${ }^{57}$ Bellamy, The Criminal Trial in Later Medieval England, 58.

58 Bellamy, The Criminal Trial in Later Medieval England, 61.
} 
and Aristotle's theories of the human body. ${ }^{59}$ Men were naturally hotter than women, and so it was in the nature of men to react in the heat of the moment, while the cold-blooded nature of women meant very few women could use this as a defense. ${ }^{60}$ In the Middle Ages, men and women understood that not all people conformed to the normative ideas of masculine and feminine, of hot and cold, but Kesselring found through an examination of early modern cases that despite this knowledge, "evading death through the charge of hot-blooded manslaughter was not an option for female killers." 61 While more women were found guilty of homicide than men, it does not necessarily mean that they were all executed; many did receive pardons, just not for self-defense. ${ }^{62}$ Kesselring's conclusions are supported by the data in the Court of Common Pleas records. None of the women in these records claimed self-defense, but they were sometimes painted as attackers against whom self-defense was necessary.

One aspect of the felony and trespass vi et armis procedures which did remain the same between the different procedural guidelines was that the defendants had to admit to the assault (or killing) in order to introduce self-defense as an option. This is why for the trespass vi et armis cases, defendants pleaded a "confession and avoidance". They admitted to the act and then offered the rationale for why they should be found innocent. While none of the cases in which the defendants pleaded self-defense have a conclusion, that this was acceptable under the law with the minimal amount of justification is clear in that the justices and serjeants at law of the Court of Common Pleas accepted it as a plea. The defendants clearly claimed self-defense as they used se defendo in their pleas, yet they did not indicate that there was no other recourse

\footnotetext{
${ }^{59}$ Kesselring, "Bodies of Evidence," 253.

${ }^{60}$ Kesselring, "Bodies of Evidence," 254.

${ }^{61}$ Kesselring, "Bodies of Evidence," 255.

${ }^{62}$ Garthine Walker, "Homicide, Gender, and Justice," in Crime, Gender and Social Order in Early Modern England (Cambridge: Cambridge University Press, 2003), 113, 124.
} 
open to them. Of course, they also did not kill the alleged victim in these cases, which might explain the difference in procedural guidelines. However, this was not the only difference between felony, misdemeanor, and trespass cases before the courts.

When examining the cases of assault before the Court of Common Pleas, especially when considering other localities and types of procedures, one notices a stark difference in how courts recorded violence. As Jenny Benham illustrates, there were certain rules within thirteenthcentury English law codes. For instance, in criminal procedures for woundings, a description and examination of the injury needed to take place. While this might not have been as detailed an inspection as what occurred in Scandinavian society, in the same era, English eyre rolls indicated what was wounded, with what, and how. ${ }^{63}$ However, all of these were absent from the assault cases enrolled on the Court of Common Pleas records at the start of the fifteenth century. None of the thirty-two cases examined in this chapter described the wounds or extent of the injuries. In fact, the language used barely indicates violence took place at all. The weapons listed, in all but four of the cases, were one of two formulaic phrases: "swords, bows and arrows", or "swords, staves, and knives". For two cases, plaintiffs identified daggers as the main weapons, an indicator, because of the departure from the formulaic phrases, that the defendant actually used these in the perpetration of the alleged assault, in the third case, the plaintiff mentioned an axe, and in the fourth case, no weapons were listed. ${ }^{64}$

In addition, clerks used the same formulaic phrases in all thirty-two cases to describe the incident: the defendant assaulted the plaintiff, and beat, wounded and ill-treated them. ${ }^{65}$

\footnotetext{
63 Jenny Benham, "Wounding in the High Middle Ages: Law and Practice," in The History of Medicine in Context: Wounds in the Middle Ages, ed. Anne Kirkham, and Cordelia Warr (Farnham, UK: Ashgate Publishing, 2014 ), 164. ${ }^{64}$ See Figure 1 on page 125.

${ }^{65}$ For example, in TNA, CP 40/577, rot. 302d., it looks like this: "Willelmus Ullesby de London attachiatus fuit ad respondendum Willelmus Bitterley de placito quare vi et armis in ipsius Willelmum Bitterley apud London insultum fecit et ipsum verberavit vulneravit et male tractavit..."
} 
Variations in this language only occurred depending on the gender and the number of defendants, plaintiffs, or victims. In two cases, they added an additional phrase, desperabat eius vita (feared for their life), which was meant to indicate the extent of the threat. Even this addition, however, did not describe the injuries incurred as a result of the assault. For cases focused on violence, in the one set of torts that one could reasonably assume that violence actually occurred, there was a surprising lack of violence in the records. ${ }^{66}$ In other types of torts covered by trespass vi et armis, assuming that violence actually took place as a result of (or while committing) a theft, abduction, or housebreaking, might be faulty. ${ }^{67}$ However, assault was, even by medieval standards, a violent act. Given there was no variation in the words used, it is impossible to ascertain the types of injuries victims incurred or how the altercations happened. Where on their bodies were the wounds? How serious were these wounds? What type of altercation was it? Did they use the weapons listed in the case? If so, would that create worse wounds than if they engaged only in hand to hand combat?

These questions are unanswerable based on the records of the Court of Common Pleas from the fifteenth century. It was as if violence was sanitized from the records. Perhaps more information came to light in the trial with witness testimony but given the time difference for some of these cases, details might also have been difficult to remember. With so little known about trial procedures in the fifteenth century, it is difficult to ascertain what was required of a defendant or plaintiff in terms of evidence or even number of witnesses. ${ }^{68}$ In one case, the initial assault took place in 1395 , while the case was enrolled in the records in $1410 .{ }^{69}$ Skoda shows in

\footnotetext{
${ }^{66}$ Skoda goes into great detail about the language used to describe a violent act and the details provided in cases of violence before various types of courts in thirteenth and fourteenth-century France. Skoda, Medieval Violence.

${ }^{67}$ I talk about legal fictions of violence in more detail in both chapters one and three.

68 J.H. Baker, The Oxford History of the Laws of England, Vol. 6 (Oxford: Oxford University Press, 2003 ), $363-363$.

69 TNA, CP 40/597, rot. 128.. Lewis Rynfeld claimed the assault took place "on the Feast of the Apostles Peter and Paul in the nineteenth year of the reign of the aforementioned Richard the late king." (In Latin it reads "in festo apostolorum Petri et Pauli anno regni praedicti Ricadi nuper Regis etc decimo nono.”)
} 
her work on France that violence, especially violence deemed unacceptable by society, left an imprint on the memories of both individuals and a community long after the events. ${ }^{70}$ The assault in the case mentioned above, Rynfeld $v$. Shyftling, might have made an indelible memory on those who witnessed it, but that they could speak to that memory fifteen years later assumes that the witnesses were a) still in the area to provide testimony and b) still alive.

For the locations of these assaults, scribes listed only the nearest parish church, which does not mean the litigants were at church when the alleged altercation occurred, but that the parish was the smallest administrative unit in which the altercation happened. ${ }^{71}$ Unfortunately none of the cases indicated when during the day these events happened. Again, time of day could communicate quite a bit about the legitimacy or illegitimacy of the violence. ${ }^{72}$ As Skoda discusses, street violence was not uncommon. ${ }^{73}$ The street was a place where various parties from all walks of life commingled. The cases, as recorded in the records of the Court of Common Pleas, give no indication as to how this violence came about: whether it was a result of a business dispute, a drunken argument, a long-festering personal dispute, a case of wrong place/wrong time, or any number of other explanations. Unfortunately, knowing some of these missing elements is crucial to understanding what the violence that occurred communicated not only about the people involved but also the issues at stake.

Even without some of the information needed to interpret what violence communicated to the individual and community, there are three cases where the plaintiff indicated that the violence was enough of a threat to fear for their lives. Two of the cases, one in 1404 and the

\footnotetext{
${ }^{70}$ Skoda, Medieval Violence, 85-86.

${ }^{71}$ See Map 2 on page 134.

72 Skoda mentions that it was more common for a case record to note when an act of violence occurred at night and so they often omitted time of day when it happened during the day. If this holds true for the Court of Common Pleas records in England, all of the torts happened during the day. Skoda, Medieval Violence, 57.

${ }^{73}$ Skoda, Medieval Violence, 59.
} 
other in 1414, followed the standard formula mentioned above in that they presented a case of assault and wounding, but each plaintiff added that as a result of the alleged assault, he feared for his life. ${ }^{74}$ What is not indicated with this phrase (ita quod de vita desperabatur) was whether this meant the alleged assault was so brutal that the victim might not have survived or whether the threat was so menacing, they feared future assaults that might lead to their death. The damages requested offer no help in understanding the possible severity of the alleged assaults; in these two cases, William Gostwyk requested 100 marks (sixty-six pounds, thirteen shillings, and four pence) and Nicholas Stodley requested forty pounds. These amounts were not any different than ones found in cases where defendants did not include the phrase. Indeed, in Gostwyk's case, the clerk only entered the phrase in the original writ, rather than in both the original writ and the count, which was how it was recorded in the Stodley court record. It is unclear whether this meant Gostwyk did not repeat this fear while in front of the Court of Common Pleas or that the clerk simply did not record it.

To further complicate this, the third case, from 1415, does not use the same phrase to indicate a fear for his life. In fact, the case uses quite a bit of language not seen in any other case I examined for this dissertation. Hugo Wyse accused seven men of assault. ${ }^{75}$ However, it was not simply assault; according to the case records, the men, "criminals and disturbers of the King's peace", assembled ahead of time and lay in wait for him to come along so that they could assassinate him. While being assaulted, "many threats to his life were heaped on him" so that he spent three months virtually imprisoned in his home "for fear of death". ${ }^{76}$ In this case, two

\footnotetext{
${ }^{74}$ After the standard Latin phrase indicating assault, "insultum fecit et ipsum verberavit vulneravit et male tractavit," "ita quod de vita desperabatur." was added. TNA, CP 40/576, rot. 250; TNA, CP 40/615, rot. 445d.

${ }^{75}$ I talk more about this case later in this chapter, where I focused on the defense used by two of the defendants. TNA, CP 40/619, rot. 359.

${ }^{76}$ Both the original writ and the count are recorded thusly in Latin, “...aggregati sibi quam pluribus malefactoribus et pacis domini regis perturbatoribus ad ipsam Hugonem interficiendum apud London insidiati fuerunt et ipsam verberaverunt vulneraverunt et male tractaverunt et ei tales et tantas minas de vita et mutilacione membrorum
} 
phrases (twice repeated) indicated the threat and fear: ei tales et tantas minas de vita and $o b$ metum mortis. This may not have been the language used by Wyse in court, but its inclusion in the case records suggests that he emphasized his fear and how the extent of that fear kept him in his home for three months, afraid to go out and suffer again at the hands of the defendants; it indicates that his fear was specific and detailed enough to warrant special language used by the clerks of the court in their case records. Alas, not all cases provided such clear-cut portrayals of fears and violence

\section{Self-Defense as Lawful Violence}

Whether the violence had actually occurred or not, fifteenth-century plaintiffs knew that, by law, the violent act they alleged had happened was an illegitimate use of violence. As Shannon McSheffrey points out, the information in the case had to be believable in order for a judge, jury, or society at large to accept it. ${ }^{77}$ The same standard applied to any defense used by the alleged perpetrators. For those defendants who did not plead "not guilty", the pressure to redraft the violence they tacitly admitted to committing as licit, or acceptable, was high. People seeking to justify their violence would pick the convention that might help them convince others. ${ }^{78}$ In nine cases, this redrafting played on the idea that, as Maddern puts it, "the exercise of violence... was thought to be essential in the maintenance of moral and civil order."79 These defendants claimed they acted out of self-defense or to restore the order that the plaintiffs, rather than themselves, had broken. However, this defense also illustrates a major difference between civil and criminal procedures in relation to self-defense and violence.

\footnotetext{
suorum imposuerunt quod idem Hugo circa negocia sua ibidem faciendum ob metum mortis per magnum tempus palam incedere non audebat sicique negocia sua praedicta per idem tempus infracta remanserunt..." TNA, CP 40/619, rot. 359 .

77 McSheffrey, "The Slaying of Sir William Pennington," 188-89.

${ }^{78}$ Brown, Violence in Medieval Europe, 18.

${ }^{79}$ Maddern, Violence and Social Order, 228.
} 
Table 5 - Details for Cases in which Defendants Used Self-Defense

\begin{tabular}{|c|c|c|c|c|c|c|c|}
\hline Case Name & Term, Year & Torts & Date & Damages & Pleading & Concluded & TNA Reference \\
\hline Bekyrton v. Hunt & $\begin{array}{l}\text { Michaelmas, } \\
1411\end{array}$ & Assault & $3 / 6 / 1411$ & $£ 200$ & Special Issue & No & CP 40/603, rot. 566 \\
\hline Bitterley v. Ullesby & Easter, 1405 & Assault & $10 / 5 / 1403$ & $£ 40$ & Special Issue & No & CP $40 / 577$, rot. $302 \mathrm{~d}$ \\
\hline Carpenter v. Dygon & Trinity, 1409 & Assault & $4 / 15 / 1409$ & $£ 136 \mathrm{~s} \mathrm{8d}$ & Special Issue & No & CP 40/594, rot. 135 \\
\hline $\begin{array}{l}\text { Ferrourv. } \\
\text { Staundon }\end{array}$ & $\begin{array}{l}\text { Michaelmas, } \\
1411 \\
\end{array}$ & Assault & $11 / 2 / 1411$ & $£ 20$ & Special Issue & No & $\mathrm{CP} 40 / 603$, rot. 502 \\
\hline $\begin{array}{l}\text { Gostwyk v. } \\
\text { Bircheundershawe }\end{array}$ & Hilary, 1405 & Assault & $11 / 17 / 1404$ & $£ 6613 \mathrm{~s} 4 \mathrm{~d}$ & Special Issue & No & CP 40/576, rot. 250 \\
\hline $\begin{array}{l}\text { Kyngeston } v . \\
\text { Domegode }\end{array}$ & Trinity, 1410 & Assault & $2 / 24 / 1410$ & $£ 20$ & Special Issue & No & CP $40 / 598$, rot. $304 \mathrm{~d}$ \\
\hline Perot v. Ussher & Hilary, 1412 & Assault & $3 / 28 / 1411$ & $£ 20$ & Special Issue & No & CP $40 / 604$, rot. $111 \mathrm{~d}$ \\
\hline $\begin{array}{l}\text { Puddyng } v . \\
\text { Tregarye }\end{array}$ & Trinity, 1406 & Assault & $3 / 25 / 1406$ & $£ 40$ & Special Issue & No & $\mathrm{CP} 40 / 582$, rot. $412 \mathrm{~d}$ \\
\hline Spore v. Smyth & Easter, 1405 & Assault & $12 / 18 / 1404$ & $£ 40$ & Special Issue & No & CP 40/577, rot. 199 \\
\hline $\begin{array}{l}\text { Wyse v. } \\
\text { Whitehed }\end{array}$ & $\begin{array}{l}\text { Michaelmas, } \\
1415\end{array}$ & $\begin{array}{l}\text { Assault } \\
\text { Imprisonment }\end{array}$ & $6 / 23 / 1415$ & $£ 20$ & Special Issue & No & CP $40 / 619$, rot. 359 \\
\hline
\end{tabular}

*In this table, I have outlined the cases from this section of chapter four. Defendants could enter four types of pleadings, those pleading "not guilty" entered a general issue. Those who disputed a point in the plaintiffs count, entered a special issue plea.

When crafting a narrative in this vein, defendants walked a fine line between what was acceptable violence and what crossed the boundaries of proper use of force. ${ }^{80}$ Unfortunately, we do not know whether these self-defense narratives were successful as none of these cases came to a conclusion in the records of the Court of Common Pleas. This also means it becomes harder to ascertain the impact of status, wealth, or gender in relation to the damages as damages were awarded in only one of the cases discussed in this chapter. In this set of special pleadings, the defendant did not deny the original assault, but instead claimed that if the plaintiff was injured it was their own fault for attacking the defendant in the first place; this was similar to felony cases involving self-defense, although not exactly the same. ${ }^{81}$ These defendants argued that it was lawful to defend themselves and others when attacked. It is perhaps telling that all of the defendants who employed a self-defense narrative were men. ${ }^{82}$ And of the nine defendants who

\footnotetext{
${ }^{80}$ See Malcolm Gaskill, "Reporting Murder: Fiction in the Archives in Early Modern England," Social History 23, no. 1 (1998), 15; Jennine Hurl-Eamon, Gender and Petty Violence in London, 1680-1720 (Columbus: Ohio State University Press, 2005), 65.

${ }^{81}$ It is probable that narratives for civil procedures could avoid the part of the account where the defendant fled their attacker until cornered because these cases only dealt with an assault rather than a death.

${ }^{82}$ This fits into the larger data on gender and violence. Women indicted for homicide rarely, if ever, used selfdefense as a plea. See Walker, Crime, Gender and Social Order, 130-31.
} 
used se defendo (to defend oneself) in their plea, three of them explicitly used the phrase prout ei bene licuit, "as was his right". This counter-narrative also put the fault of the disorder back onto the plaintiff and painted the defendant as the restorer of order. One of the cases does this by specifically casting the defendants as the pacifiers of a violent altercation between two other men. Of course, the plaintiff provided quite a different narrative, one of an innocent victim who was attacked and was seeking redress for the wrong done.

The Carpenters were two such plaintiffs. In the summer of 1409, they sued John Dygon, a London butcher. He was accused of assaulting Agnes, wife of Solomon Carpenter, in April of that same year. The Carpenters claimed twenty marks, just over thirteen pounds, in damages as a result of the injuries Agnes suffered when Dygon allegedly attacked her. ${ }^{83}$ Dygon went to court to proclaim his innocence of any wrong doing. He argued that he never broke the peace nor purposefully set out to harm anyone. There was no force and arms. ${ }^{84}$ According to his narrative, Agnes attacked him. He had no choice but to defend himself, so, "he says that if some harm happened to Agnes, then it was due to her own assault" of him. ${ }^{85}$ Unfortunately, we have no idea why either Dygon or Agnes might have been driven to assault the other as the motives do not make it into the records. Nor do we know whether Agnes or her husband, Solomon, was the one to speak in court. ${ }^{86}$ Dygon made no claims to have acted lawfully as some defendants did;

\footnotetext{
83 TNA, CP 40/594, rot. 135.

${ }^{84}$ This is very common in special issue cases. Defendants deny the force and injuries and the breaking of the king's peace before pleading a special issue (or "confession and avoidance") about the main wrong, in this instance, the assault. It is formulaic language; here is how it looked in the Carpenter v. Dygon case: "venit et defendit vim et iniuriam quando etc., Et quo ad venire vi et armis seu quicquid quod est contra pacem Regis dicit quod ipse in nullo est inde culpabilis.”; “...comes and denies the force and injuries when, etc. And as for the coming with force and arms or whatever is against the peace of the king, he says that he is in no way guilty."

${ }^{85}$ TNA, CP 40/594, rot. 135: "dicit quod si malum aliquod eidem Agneti adtunc evenit hoc fuit ex insulto suo proprio."

${ }^{86}$ Throughout the fifteenth-century, married women were not supposed to appear before any court without their husband. For a more detailed discussion of this, see Matthew Frank Stevens, "London Women, the Courts and the 'Golden Age': A Quantitative Analysis of Female Litigants in the Fourteenth and Fifteenth Centuries," London Journal 37, no. 2 (2013), 75-76.
} 
instead, he emphasized that he felt threatened and did what was needed to fend off Agnes's assault. It is unclear at this stage whether the gender or occupation of the plaintiffs played a role in either the amount requested in damages or in the crafting of Dygon's narrative as four other defendants did not use the phrase prout ei bene licuit and the attackers in those cases were men. ${ }^{87}$ However, Dygon, with this defense, claimed that defending oneself, even from a woman, was a licit use of violence, even though the statutes categorized assault as illicit. ${ }^{88}$

In another case, a London butcher, William Smyth, along with his accomplice, John Ludby, and accessory, Walter Haynds, stood accused of assaulting William Spore in $1405{ }^{89}$ Spore felt the injuries from the alleged assault were worth forty pounds, a hefty sum, more than the twenty marks asked for by the Carpenters in the first case. In this case, the two defendants entered separate pleas: Smyth entered a "not guilty" plea, while Ludby pleaded a special issue. ${ }^{90}$ Ludby crafted a narrative in which Spore was the initiator of the altercation on that December day and he (Ludby) was defending himself. Much like Dygon, Ludby made no claims to be acting as a good man or lawfully. This could be because he assumed that defending oneself was always right and expected. From the information in the enrolled plea, we cannot know the full story behind the altercation. We do know that Ludby wanted to be sure that the courts had it on record that he was not an instigator in the assault. This could be because Smyth did not have a reputation for violence and so felt that denying all charges would be the best route. If he was generally seen as a non-violent man, he would not have to offer a defense, but could expect the

\footnotetext{
${ }^{87}$ Bene licuit was not an uncommon phrase across the spectrum of legal documents and court records, but it is curious that clerks only recorded it in some of these special pleadings and not others.

${ }^{88}$ Teresa Phipps found similar results in the lower courts. Teresa Phipps, "Misbehaving Women: Trespass and Honor in Late Medieval English Towns," Historical Reflections 43, no. 1 (2017), 67.

${ }^{89}$ TNA, CP 40/577, rot. 199. This case was before the court later in 1405.

90 TNA, CP 40/577, rot. 199: "Et praedictus Willelmus Smyth dicit quod ipse non est culpabilis de transgressione praedicta..."; "And the aforementioned William Smyth says that he is in no way guilty of the aforementioned trespass..."
} 
jury of his peers to judge his actions fairly. Ludby, on the other hand, might have had a reputation for illicit violence and so needed to provide more in his narrative for why his violence in this case was a licit act. This is impossible to know without corroborating evidence. ${ }^{91}$

Similarly, when Thomas Hunt, a barber, along with William Maydeston appeared before the Court of Common Pleas, they felt that crafting a narrative that rested on the acceptable use of violence in their defense was a good tactic. ${ }^{92}$ Henry Bekyrton claimed that in the spring of 1411 Hunt and Maydeston assaulted him. ${ }^{93}$ Bekyrton asked for 200 pounds in damages, which leads one to the conclusion that either the injuries sustained by Bekyrton in the altercation were extensive or that the combination of Hunt and Maydeston led Bekyrton to believe he could obtain such a large sum of money. Perhaps Hunt had a lucrative business as a barber.

Maydeston's occupation was left out of the record, but he may have been a fishmonger, which was one of the most prestigious merchant companies in London. ${ }^{94}$ Just as happened in the Spore v. Smyth case, there were two separate pleas entered. Maydeston entered a simple "not guilty" plea, and Hunt pleaded a special issue, citing that he was defending himself. He claimed that on the day, time, and location laid out in the original count that Bekyrton had attacked him, "wishing to beat and wound him [Hunt]." "95 And while Hunt made no claims to acting as was proper in his defense, he nevertheless asserted that if Bekyrton incurred any injuries it was his own fault. ${ }^{96}$ As with the case of Ludby, if Hunt had a reputation of being violent in illicit ways,

\footnotetext{
${ }^{91}$ Ludby had at least one other trespass vi et armis case before the Court of Common Pleas moving through the court between 1400 and 1401. TNA, CP 40/559, rot. 562; TNA, CP 40/560, rot. 109. Between 1422 and 1427, he had four other cases, one of which was another trespass vi et armis, which came before the Court of Common Pleas. TNA, CP 40/650, rot. 395d; TNA, CP 40/665, rot. 453d; TNA, CP 40/667, rot. 390d; TNA, CP 40/670, rot. 326. 92 TNA, CP 40/603, rot. 566.

93 The case was entered into the Michaelmas rolls later that year.

94 "Fines for Divers and Other Counties: Henry IV," in A Calendar to the Feet of Fines for London and Middlesex: Volume 1, Richard I - Richard III, ed. W.J. Hardy, and W. Page (London: Hardy \& Page, 1892).

95 TNA, CP 40/603, rot. 566.: "Thomas dicit quod praedictus Henricus actionem trans gressione inde versus eum habere non debet quia dicit quod idem Henricum die anno et loco praedictis in ipsium Thomam insultum fecit et ipsium verberasse et vulnerasse voluit per quod ipse erga praefatum Henricum adtunc se defendebat."

96 TNA, CP 40/603, rot. 566.: "ita quod si quod malum eidem Henricum tunc ibidem evenit hoc fuit de insultum suo
} 
he may have needed to assert more forcefully that the violence in this instance was licit.

Three other cases make the same assertion of defending oneself, but without claims within the case of acting lawfully or as was proper. That either the defendant or the clerk did not include this language does not take away from them crafting a narrative that drew on a recognized social mores that some violence was permitted by men of good-standing. ${ }^{97}$ In each case, there was one defendant and one plaintiff and so they would seem to be fairly straightforward instances of interpersonal violence. Thomas Perot accused William Ussher of assault early in 1412; Perot made no claim of fearing for his life and Ussher, while denying the force and arms, countered Perot's narrative with one that made Perot the instigator of the assault. ${ }^{98}$ A similar narrative can be seen in the case, from 1406, where John Puddying accused Walter Tregarye of assault and in the case of William Buterley from 1405, who was allegedly assaulted by William Ullesby. ${ }^{99}$ The Buterley v. Ullesby case, however, does go through a few stages of pleading before Ullesby ended with the "defending himself" narrative. This was not uncommon in cases, where defendants would try out a few types of defenses until one seemed likely to work in front of a jury.

Other cases do explicitly include the idea of violence being lawful, such as the one between John Ferrour and John Staundon and Simon Cok. ${ }^{100}$ Ferrour accused both Staundon and Cok of assaulting him late in 1411. Ferrour made no claims to fearing for his life and requested twenty pounds in damages. Both Staundon and Cok pleaded a special issue, claiming that they

proprio in defensionem corporis ipsius Thome."

${ }^{97}$ I add good standing here because Barbara Hanawalt makes clear that being of good repute is what made one's actions acceptable, even when those same actions would be unacceptable from someone of ill-repute. Hanawalt, 'Of Good and Ill Repute, ' 7-8. I discuss this in more detail in chapter three, but also see Brown, Violence in Medieval Europe; Kaeuper, Chivalry and Violence in Medieval Europe; Maddern, Violence and Social Order; Skoda, Medieval Violence.

98 TNA, CP 40/604, rot. 111d.

99 TNA, CP 40/582, rot. 412d; TNA, CP 40/577, rot. 349.

100 TNA, CP 40/603, rot. 502. 
were defending themselves in the altercation. According to their narrative, Ferrour assaulted them first and they acted "as was their right [to do]." ${ }^{101}$ As with all the other cases previously mentioned, the plaintiff entered a rejoinder, one in which they attempted to undermine the narrative of the defendants by claiming they were lying. Ferrour reasserted that it was Staundon and Cok who were responsible for the violence, not him. Bene licuit was not an uncommon phrase in the legal documentation of England, used in charters by kings and burghers to explain their rights under law as well as other types of cases, both civil and criminal. The clerks recording the cases for the plea rolls would have been well aware of this concept, but so too would the people appearing before the courts, the defendants and plaintiffs. Perhaps they did not know the phrase in Latin, but the social mores of the time allowed for a certain amount of violence and this was what they used when crafting their narratives. ${ }^{102}$ What they were negotiating in front of the courts was whether this particular act of violence counted as licit or illicit. For example, in Ferrour v. Staundon, Ferrour felt it was illicit violence; Staundon and Cok argued it was licit violence.

Continuing this idea of acceptable violence, William Gostwyk, a cordwainer, accused John Bircheundershaw, a dauber, of assault in January of $1405 .{ }^{103}$ We could assume that this was worse than the assault on either Spore or Agnes Carpenter because Gostwyk claimed he "feared for his life." In addition, Gostwyk requested 100 marks in damages. ${ }^{104}$ That is sixty-six pounds, thirteen shillings, and four pence, twenty-six pounds more than Spore requested. The amount could reflect the extent of the injuries, the loss of money to his business, but it could also reflect

\footnotetext{
101 TNA, CP 40/603, rot. 502.: “adtunc ibidem se erga praefatum Johannem Ferrour defendebant prout eis bene licuit"

102 See Hanawalt, 'Of Good and Ill Repute, ' 8-9; Hurl-Eamon, Gender and Petty Violence in London, 65.

103 TNA, CP 40/576, rot. 250.

104 TNA, CP 40/576, rot. 250.: "ita quod de vita eius desperabatur..."; "so that he feared for his life..." This phrase makes it into a few assault cases and its ramifications were discussed earlier in the chapter.
} 
how Gostwyk valued his reputation. Bircheundershaw created a narrative in his own defense that put the blame back on Gostwyk, claiming that if Gostwyk was injured it was his own fault as Gostwyk attacked him first and he was just defending himself, "as was his right."105 Defendants (or the clerks) used these phrases to indicate that there was violence not only permitted by social mores, but by law as well. There were regulations as to amount of force allowed, legally speaking. One could not employ more force or violence than was used on oneself. For example, one could not legally use a weapon against an unarmed opponent and call it self-defense or legally excused violence. ${ }^{106}$ Self-defense in felonies using criminal procedures had strict parameters in order to qualify for a pardon. That there were different standards between trespass and felony when claiming self-defense does not mean those standards are not relevant, it could simply reflect societal ideas of a fair fight. It is intriguing to note that Bircheundershaw did not deny assaulting Gostwyk, nor did he deny the extent of Gostwyk's injuries or fears. That Bircheundershaw had to explicitly say that he acted as was proper, or that the scribe chose to include it in this case, indicates more explicitly this idea that certain types of violence were justified; although it is unclear why the phrase was used in some cases but not others. Whatever the motivation, the language in the case indicates that he felt justified in carrying out violence against Gostwyk. He argued that if Gostwyk feared for his life then he should not have attacked Bircheundershaw in the first place. Perhaps a medieval, "he got what was coming to him"?

The idea of lawful violence is also seen in a case in which several glaziers allegedly assaulted Hugo Wyse, whose occupation was not included. ${ }^{107}$ In addition to the assault, the group of six glaziers and one builder allegedly scared Wyse so badly that starting in June of

\footnotetext{
105 TNA, CP 40/576, rot. 250.: "per quod idem Johannes erga praefatum Willelmum se defendebat prout ei bene licuit"

106 Green, "Societal Concepts of Criminal Liability," 669

107 TNA, CP 40/619, rot. 359.
} 
1415, he refused to leave his home for three months. ${ }^{108}$ According to Wyse's narrative, not only did the group of men surprise him by beating and wounding him, but they also conspired to murder him at the instigation of some unnamed person. ${ }^{109}$ Although it seems the defendants all used the same attorney and may not have actually been in court at all, this case also involved separate pleadings as some of the cases mentioned above did, five of the seven entered a simple "not guilty" plea. However, two pleaded a "confession and avoidance"; John Cok and John Carpenter both countered Wyse's narrative, claiming that there was no conspiracy in the attack, and no one ordered Wyse's death. Further, they asserted that Wyse assaulted them, and they were only defending themselves as "was their right." 110 This case is interesting on a number of levels; first, it includes the largest number of defendants I have seen in any assault case in the records so far. ${ }^{111}$ Second, it mentions allegations of conspiracy and the ordering of the death of Wyse. And third, and perhaps most significant, is that Wyse claimed to have been terrorized by these men to the point of not leaving his home for three months and he only asked for twenty pounds. ${ }^{112}$ It seems strange, too, that Cok and Carpenter used the narrative of lawful violence when there were so many defendants in the case; why did the other defendants not use this defense? Their plea gives no indication that the other men listed in Wyse's count were absent from the event. Although two men against one does not necessarily indicate that Wyse might not have initiated the altercation as the men assert. It could be that when Wyse crafted his narrative

\footnotetext{
${ }^{108}$ Robert Whitehed, Thomas Essex, Roger Mershfeld, John Cok, Richard Sharp and John Petworth were listed as being glaziers and from London. John Carpenter was the lone wright (or builder) but was also from London. 109 This type of conspiracy was a heavy charge and the language of the case is quite different in introducing the assault: “...de placito quare vi et armis aggregati sibi quam pluribus malefactoribus et pacis domini regis parturbatoribus ad ipsam Hugonem interficiendum apud London insidiati fuerunt..." TNA, CP 40/619, rot. 359. 110 TNA, CP 40/619, rot. 359.: "adtunc ibidem erga ipsam Hugonem se defendebant prout eis bene licuit" 111 A case from 1412 had seventeen defendants. TNA, CP 40/605, rot. 334d.

112 Value would be relative, of course. Twenty pounds could equal several years' worth of income or it could just barely cover what he lost from missed work during that three months he was too scared to leave his house, plus the court costs.
} 
of the assault, he added more assailants than were actually there. Or, that Wyse's account was accurate in the number of men present, but that their simple "not guilty" pleas indicated they did not take part in the assault and had only witnessed the altercation between Ware and Cok and Carpenter, or that they thought their reputations would hold with the jury. ${ }^{113}$ Much of this is conjecture when there is no resolution to a case, but it does illustrate that defendants chose different strategies, even in the same case.

For any of these cases, the creation of the narrative could be seen as an ordering mechanism. In each case, both the plaintiffs and the defendants told their side of the story. In Carpenter v. Dygon, we have an account from both parties. ${ }^{114}$ Ascertaining the "truth" would have been hard enough at the time the incidents occurred, and this far removed in time, there is no way to know which side was telling the "truth" or even how the cases worked out in the end, but we still have the stories they told. The Carpenters' suit indicates they may have felt they were wronged, and they wanted that wrong addressed. ${ }^{115}$ Dygon could have been painting Agnes or her husband in a bad light and so they sued to get their side of the story out there. A person's or family's name was a valuable commodity and once lost was not easily regained. And while these accounts may not have been explicitly about maintaining reputation, the narratives crafted by both defendants and plaintiffs still tried to put themselves in the best light. The same could hold true for Wyse v. Whitehed and Kyngeston v. Domegode. ${ }^{116}$ Wyse may have wanted people to know that he did not just up and run away for three months or Kyngeston may have wanted it on record that the Domegode family was prone to violence.

\footnotetext{
${ }^{113}$ In a felony case this would make them equally culpable in the assault, but perhaps they were counting on a jury not enforcing that particular legal parameter in a civil procedure.

114 TNA, CP 40/594, rot. 135.

${ }^{115}$ Whether that wrong was the actual violence as alleged in the suit or something other action is unknowable.

116 TNA, CP 40/598, rot. 304d; TNA, CP 40/619, rot. 359.
} 
In a civil suit, the other side gets their chance at maintaining their good name as well. They could make claims, on legal record, to have acted in defense of themselves as was lawful or expected of good men. In four of the cases, defendants use this theme of restoring or maintaining order in their plea. In ten of the cases, the defendants put the fault of the disorder back on the plaintiffs again, in other words, getting into the record their own version of ordering the events. In the Kyngeston v. Domegode case, we have Kyngeston's side of the story, one he has crafted to put the Domegodes in a bad light. But on their end, Walter and John Domegode have portrayed Kyngeston as an instigator, as attacking William first. When good men, as Walter and John claimed to be, see a wrong like that (let alone against their family), they apparently felt that it was their duty to intercede. In this way, we see a double attempt at creating order, not only did they impose order on the fight between Kyngeston and William Domegode, but they also reordered the events as laid out by Kyngeston.

While each of these cases are formulaic in language, the inclusion of certain phrases such as "lawful" in some of the cases, but not others, may indicate that those men felt they were not being disorderly, but rather were restoring order. If this were part of the formula of a self-defense plea, it would be in a majority of the records, not just some of them. The words in the plea records are not the words of the defendant, but they still have to represent what the defendant (or their attorney) said in court and what the defendant (or their attorney) suggested might be believable to their peers. I am not suggesting that these defendants knew the phrase bene licuit; however, given the likely exposure to courts in their daily life around London, and the ubiquity of the phrase in other types of records, it is not beyond the realm of possibility. Regardless, they certainly understood the concept and used it in their pleas before the court. ${ }^{117}$ In some instances,

\footnotetext{
${ }^{117}$ Many historians discuss concepts of violence and how people were socialized to understand what was acceptable and what was not. I discussed them in more detail in both chapter one and chapter three. To begin an overview of
} 
the defendants (or the clerks writing up the plea roll) invoked the idea of what a good man ought to do, indicating that a good man defends himself and others who come under attack. In most, they put the blame back on the plaintiff, as in "if they didn't want to get hurt, they shouldn't have started something they couldn't finish.”

\section{Conclusion}

The contestation between law and society over what counted as licit and illicit violence was centuries old by the time any of these litigants appeared before the Court of Common Pleas. One could say the same of the use of trespass vi et armis as a legal fiction. As Brown pointed out, litigants used vi et armis as an add-on to other wrongful acts long before it became a writ category unto itself. However, what is in question is not when or how trespass vi et armis came into being, but rather how historians have interpreted it. Some scholars focus on it as a tool to get a non-violent case heard by a royal justice or in a central court; others categorize the cases as symptoms of larger disputes, usually over land. ${ }^{118}$ Neither view stops to assess these cases for what they can show us about violence: its conceptualization, its negotiation, or the experiences of it. Therefore, while one cannot prove the truth in any of these cases, which is not the point, they do reference ideas about violence. Some defendants admitted to violence, others denied it; but either way the litigants had to present a believable portrayal for the courts and jurors. One could not take for granted that other people regarded violence in the same way as oneself, so one had to make an argument why their view was acceptable.

Violence in the Middle Ages was not resoundingly condemned, nor was it

\footnotetext{
this, please see Brown, Violence in Medieval Europe; Barbara Hanawalt, and David Wallace, Medieval Crime and Social Control (Minneapolis: University of Minnesota Press, 1999); Kamali, "Felonia Felonice Facta"; Skoda, Medieval Violence.

118 See the discussion in chapter one for these various interpretations of trespass vi et armis.
} 
unquestioningly supported. The debates by contemporaries surrounding violence were nuanced, considering many factors, including the gender and status of the people involved, the motivation behind the violence, the reputation of the litigants, and even location and time of day. With these factors in mind, what is clear from these cases is that medieval people catalogued violence into licit and illicit types: that which was acceptable and that which was not. For the most part, licit violence was limited to the government and government-sanctioned representatives. The law allowed violence in the capture, treatment, and pleading of defendants; ${ }^{119}$ essentially, it allowed private individuals to be violent, as in the Creyk v. Capon case in which Capon was allegedly acting on behalf of a court. Maddern suggests that "the law, then, may have functioned less to punish violence than to determine who was authorized to use it." ${ }^{120}$ Some of the cases I examined in this chapter illustrate this concept by using a defense whereby the defendants argued they should not be punished for using violence as it was a licit use of it. Even though it was not on behalf of a court or the government, these defendants' pleas asserted that they had the authority to use violence in defense of self. However, the plaintiffs who brought the suits argued that the violence done to them was illicit and the alleged perpetrators should make reparations to them. While the language the clerks employed glossed over the possibly very real violence done to these plaintiffs, one can gain an understanding of what society viewed as licit and illicit violence. Additionally, the cases reveal, albeit without much descriptive language, the experience of the alleged victims.

These cases also serve as an example of the differences in criminal and civil procedures

\footnotetext{
${ }^{119}$ Usually this was only in pursuit of those accused of felonies, minimally for those accused for misdemeanors. If a defendant refused to enter a plea during a criminal proceeding, they would be forced to do so through a process known as peine forte et dure. There is no indication that pleas were forced from defendants in private actions. Thomas A. Green, Verdict According to Conscience: Perspectives on the English Criminal Trial Jury, 1200-1800 (Chicago: University of Chicago Press, 1985), 15.

${ }^{120}$ Maddern, Violence and Social Order, 72.
} 
for defendants who claimed to have acted in self-defense. While criminal procedures for misdemeanor wounding cases, and even felony homicide cases, gave some indication of how the wounding or killing occurred as a part of the court records, this was not the only difference in procedures. Men accused of homicide had the chance to introduce mitigating circumstances of acting in the heat of the moment or killing in self-defense to reduce their culpability and therefore punishment; although this was not available to women. Women, in addition, did not use self-defense in any of the court records I examined for this dissertation. However, in a felony homicide case, the defendant would not only have had to be found guilty of the killing, but also have had to adhere to a strict narrative in order to be eligible for a royal pardon. These guidelines were not imposed on self-defense pleas entered in the records of the Court of Common Pleas. In those cases, though, the defendants did have to enter a "confession and avoidance" plea in which they admitted to the violence of which they were accused. While the defendants in both homicide self-defense cases and trespass vi et armis cases had to confess to the violence, only in the case of homicide did they have to await a pardon; in trespass vi et armis, they could be vindicated with the verdict from the jury. The differences in procedures also means that defendants in the trespass vi et armis cases had less of a burden of proof, or perhaps no reason to fictionalize the events of their self-defense.

In some cases discussed in this chapter, it is unclear whether violence actually occurred or whether plaintiffs employed a variety of fictionalized narratives in their cases. In those questionable cases, it would still be wrong to dismiss the case as being able to tell us nothing about violence in the fifteenth century. The plaintiff's narration of experiencing violence, even if fabricated, had to seem real enough to convince a jury, if the case got that far. Additionally, these cases illustrate how violence might have been experienced: stealing cash from a servant, 
breaking into a home, recovering or obtaining writs of debt, abducting women or servants, defending oneself, or pursuing justice for another court. Sometimes violence did not need additional wrongs; people might resort to violence in the heat of an argument, in response to inflammatory words, in self-defense, or attempting to recover a debt. In at least sixteen of the cases, defendants admitted to the violence of which someone accused them, furthering the idea that historians limit themselves if they dismiss all trespass vi et armis cases as fabrications. Cases in which the defendants acknowledged the violence in question not only show that violence did, indeed, happen but also provide further nuance to concepts of licit and illicit acts of violence. Violence in self-defense, in the defense of others, or to recover property were (by the defendants at least) considered licit. Defendants who used these claims in their pleadings played on social mores rather than on the laws themselves. 


\section{Chapter 5 - Pursuing Justice: A Century of Force and Arms}

\section{Introduction}

During the Easter law term in 1480, John Breynton, an under-clerk for the Court of Common Pleas, sued Eleanor Phillip for twenty pounds. ${ }^{1}$ According to his count, Phillip assaulted him and held him prisoner for twenty-four hours. He sought recompense for the wages lost during his alleged abduction and injuries he received during the incident. Breynton was successful in his suit and was awarded, by the court, a total of ninety-three shillings and four pence for his trouble, roughly twenty-four percent of what he requested. ${ }^{2}$ This case represents the intersection of multiple sites of analysis I explore in this chapter through statistical analysis: gender, occupation, and litigant motivations. It was also a rare instance in which a fairly substantial amount of damages awarded. Breynton, like other men before him, was not reticent in seeking damages against a woman through which process he admitted to being assaulted and imprisoned by her. In this instance, it was a woman acting alone, a rare occurrence compared with the cases examined in the above chapters. The records do not indicate how she might have made a living. However, her sureties included two gentlemen, a barber, and a baker, which may indicate her business associates or networks. Knowing how Phillip earned money would have helped illustrate whether Breynton's damage request was based on her income, his income, or a combination of the two.

In this chapter, I use statistical analysis to contextualize the eighty-two cases examined

\footnotetext{
${ }^{1}$ The National Archives, CP 40/872, rot. 442d; hereafter TNA. It is possible that he served as a clerk to John Browne, who was the third prothonotary of the Court of Common Pleas in 1480. J.H. Baker, The Men of Court 1440 to 1550: A Prosopography of the Inns of Court and Chancery and the Courts of Law (London: Selden Society, 2012), 363.

${ }^{2}$ As a clerk of the court, Breynton could use the court for any action, and being a clerk of the court might have made it more likely for him to win the case.
} 
qualitatively throughout the rest of this dissertation by adding in 872 cases from a more expansive dataset to examine larger trends of gender, status, and damages. The quantitative approach for this chapter rests upon a dataset that is both broader in time and geographic area than those cases from predominately London at the start of the fifteenth century that I examined already. While my dissertation data suggests that damage requests in cases involving women were lower than those involving men, as were damage requests in cases involving lower status litigants when compared with landed or titled litigants, this larger dataset reveals that these trends were not anomalies of a certain time and place. Examining case data from across the century also allows an exploration of change over time in regard to litigant stratagems, the heart of this dissertation. Cases in the Court of Common Pleas not only demonstrate that litigants continued to use the system to achieve their own ends, but also to negotiate over concepts of licit and illicit violence. The cases explored in detail above have offered scintillating stories about violence, wayward women, and stolen trees; however, the statistical analysis in this chapter will allow me to examine larger trends and suggest big picture conclusions.

Previous scholarly projects examine long term trends using cases from the Court of Common Pleas. Matthew Frank Stevens has demonstrated the advantages of this long view in a variety of articles and book chapters concerning Londoners and debt. ${ }^{3}$ As Stevens acknowledges in the openings of these studies, they were made possible by a funded research project, of which

\footnotetext{
${ }^{3}$ Matthew Frank Stevens, "Failed Arbitrations before the Court of Common Pleas: Cases Relating to London and Londoners, 1400-1468," Journal of Legal History 31, no. 1 (2010); Matthew Frank Stevens, "Londoners and the Court of Common Pleas," in London and Beyond: Essays in Honour of Derek Keene, ed. Matthew Davies, and James A. Galloway (London: Institute of Historical Research, 2012); Matthew Frank Stevens, "London Women, the Courts and the 'Golden Age': A Quantitative Analysis of Female Litigants in the Fourteenth and Fifteenth Centuries," London Journal 37, no. 2 (2013); Matthew Frank Stevens, "London's Married Women, Debt Litigation and Coverture in the Court of Common Pleas," in Married Women and the Law in Premodern Northwest Europe, ed. Cordelia Beattie, and Matthew Frank Stevens (Woodbridge, UK: Boydell Press, 2013); Matthew Frank Stevens, "London Creditors and the Fifteenth-Century Depression," Economic History Review 69, no. 4 (2016).
} 
he was a part: "Londoners and the law: pleadings in the Court of Common Pleas, 1399-1509."4

Working with him, and quite possibly several other researchers, was Jonathan Mackman.

Mackman has also published articles using information gathered by the research project,

although he seems to prefer close studies focusing on one case with intricate pleadings. ${ }^{5}$ The data from the "Londoners and the law" project is available online at British History Online. ${ }^{6}$

According to $\mathrm{BHO}$, the information was born digital, which means that while the researchers involved in "Londoners and the law" may have had physical copies, BHO has only held it in digital format. ${ }^{7}$ Using the dataset put together by Mackman and Stevens, I can analyze trends relating to gender, occupation, and status, as well as defense strategies across the fifteenth century and England.

I added the information contained in Mackman's and Stevens's online summaries of court cases, available at BHO, "Court of Common Pleas: The National Archives, CP40 13991500 " to the eighty-two cases of my dissertation dataset. ${ }^{8}$ The online summaries I used from this dataset totaled 892 entries, combined with my own dataset of eighty-two entries creates a new total of 974 entries used for statistical analysis. Mackman and Stevens, "Common Pleas," was born out of two separate projects related to Londoners; one of these concerned the law and pleadings before the Court of Common Pleas (discussed above) and the other examined women and the economy in relation to the Black Death. ${ }^{9}$ These projects skipped large swaths of time;

\footnotetext{
${ }^{4}$ Stevens, "London Creditors and the Fifteenth-Century Depression," 1087. Hereafter, "Londoners and the law."

5 Jonathan Mackman, "'Hidden Gems' in the Records of the Common Pleas: New Evidence on the Legacy of Lucy Visconti," in Rule, Redemption, and Representations in Late Medieval England and France, ed. Linda Clark (Woodbridge, UK: Boydell Press, 2008); Nigel Saul, Jonathan Mackman, and Christopher Whittick, "Grave Stuff: Litigation With a London Tomb-Maker in 1421," Historical Research 84, no. 226 (2011).

${ }^{6}$ Hereafter, BHO.

7 “Technical Methods.” British History Online (2010): https://www.british-history.ac.uk/about\#technical.

${ }^{8}$ Hereafter, I will refer to this dataset as Mackman and Stevens, "Common Pleas". Jonathan Mackman, and Matthew Frank Stevens, "Court of Common Pleas: The National Archives, CP40 1399-1500." British History Online (2010): accessed 3/16/2019, https://www.british-history.ac.uk/no-series/common-pleas/1399-1500.

${ }^{9}$ Mackman, and Stevens, "Common Pleas."
} 
they including cases from only the following years: 1400-1409, 1420-1429, 1445-1450, 1460 -

1468,1480 , and 1500 . It is not clear why they chose those particular years; however, the snapshots of time provide context for the eighty-two cases I examine closely. As explained in their introduction to the "Common Pleas," they summarized longer entries and provided translations for shorter cases, although all the work is considered to be in draft form. ${ }^{10}$ While the data was born digital, as it were, it is not in a readable format. ${ }^{11}$ In total, their project contains almost 6,300 entries spanning thirty-seven years and includes every type of action enrolled on the Court of Common Pleas records pertaining to London and Londoners. Therefore, I went through each of their entries to pull the data manually into my dataset. I searched through the entries at $\mathrm{BHO}$, pulling all those that were listed as trespass vi et armis actions by Mackman and Stevens, which resulted in 892 entries. ${ }^{12}$

There are two major ramifications of the goals of the original projects, in terms of cases included and data collected, on my study. First, Mackman and Stevens used a broader sample than I did, including cases registered not only in London, but also any case that included at least one Londoner. These parameters their cases come from a range of counties in England, not just London. Second, the questions Mackman and Stevens were interested in examining do not correlate with the ones I undertook to answer in this dissertation. It also means that some of the data I collected from my work with the Court of Common Pleas records were not contained in the summaries for the remainder of the century. For example, the summaries in Mackman and Stevens" "Common Pleas" do not record what types of weapons were listed in the cases, where

\footnotetext{
${ }^{10}$ Mackman, and Stevens, "Common Pleas." In Appendix G page 229 the Breynton v. Phillip case is an example from the Mackman and Stevens, "Common Pleas" project.

${ }^{11}$ In other words, it is not possible to download an Excel spreadsheet of their data.

${ }^{12}$ For statistical purposes in both my own dataset and that from Mackman and Stevens "Common Pleas" I combined entries that were enrolled in multiple terms, but where continuations of an action rather than a new action.
} 
as I did make note of them. ${ }^{13}$ Despite these differences, this data can still show trends in damage requests and change over time in terms of defendant strategies, which will help to place the findings of my dissertation in a broader context.

Regardless of these discrepancies between research projects, the information recorded by Mackman and Stevens remains useful for statistical analysis. Using a program called FileMaker, I input the information contained in my set of sources, as well as that gleaned from Mackman and Stevens's work. I parsed this information down to the smallest details. I created categories for the types of torts listed within the records, the date of the event, location, any weapons listed, descriptions of the goods stolen or damages done to property, length of any abduction or imprisonment, the damages requested, the outcome (if there was one recorded), and pleas of the defendants. ${ }^{14}$ Of particular interest to a statistical analysis of litigants' savviness was the number and gender of plaintiffs and defendants, the occupations and status of the plaintiffs and defendants, and the types of defenses used during the pleading process. For this last category of analysis, I noted whether defendants pleaded "not guilty", imparled until the next session, pleaded a special issue, or pleaded guilty. ${ }^{15}$ In terms of special pleadings, I then further broke these down by type of defense used: self-defense, prior arbitration, alibi, quitclaim, self-help, and technicalities. These are not categories that would have been in use in the fifteenth century, but ones that I employed for my analysis. Using these categories helped me organize the variety of special issue pleadings present in the records. I closely read the narratives offered by defendants in their pleadings to decide which case belonged in which category. The most useful categories

\footnotetext{
${ }^{13}$ It is clear that they did not provide the full transcription of these cases. For example, I only have two cases out of eighty-two which did not list weapons in my own dataset.

${ }^{14}$ See the images in Appendix $\mathrm{H}$ beginning on page 230.

${ }^{15}$ For my own dataset, I did not include cases where defendants requested the right to imparl; however, Mackman and Stevens did. Also, while I included "guilty" as an option, none of the defendants in any of the 974 cases actually pleaded guilty.
} 
for analyzing negotiations about licit and illicit violence were self-defense and self-help.

Adding the 892 cases from Mackman and Stevens's "Common Pleas” project provides a broader sample set, covering thirty-five years total, but spread throughout the fifteenth century, bringing the total number of cases used to 974 in the dataset from which I conduct statistical analyses. Examining cases through statistical analysis does have its limitations, but it also has its advantages. Conscious and unconscious biases influenced how people viewed, interacted with, and valued both objects and other people. In the records of the Court of Common Pleas, no one explicitly said they were asking for a specific amount of damages because the defendant was a woman or that they, as the plaintiff, needed a certain amount because they owned a lucrative business. As often happens with social norms, they were expressed or drawn upon without specific reference and perhaps without even consciously thinking about them. This can stymie any investigation into the past, but especially when one seeks to uncover why a certain value was placed on a certain action or object. Statistical data, along with an understanding of the context, can help bridge the gap between the unknowable and knowable, revealing social norms even if in broad strokes. Isolating the ways gender, occupation, status, and value interacted in the records of the Court of Common Pleas point to potential biases that operated on historical actors.

In the first section of the chapter, I examine what the statistical data concerning gender demonstrates about societal norms in fifteenth-century England. This analysis reinforces certain gendered expectations of the time but defies others. Analyses of status and occupation in these almost 1,000 cases were more difficult to undertake than of gender. Merging my two sets of results became somewhat problematic as a new statute in 1413 required defendants to have an occupation or status listed, the Statute of Additions. ${ }^{16}$ These records suggest that societal norms

\footnotetext{
${ }^{16}$ See Statute of Additions in 1413 (1 Hen. V, c. 5). The Statutes of the Realm, vol 2: 1377-1504 (London: 1816),
} 171. 
governing gendered behaviors changed over time, but at a slower pace than social hierarchies did. In the second section of the chapter, I reconstruct some of the social hierarchies in place as revealed in these cases, and I focus at length on what the statistical analysis of damages says about value in terms of status and occupation. Finally, I end this chapter by revisiting the main argument of my dissertation and reflect upon how statistical analysis of nearly 1,000 cases reveals the extent to which individuals in the fifteenth century continued to use the system not only for their benefit, but also to negotiate concepts of licit and illicit violence. Certain trends relating to violence remained relatively stable throughout the century.

Overall, the statistical examination of a larger dataset that I pursue in this chapter serves three purposes. First, the larger sampling of cases from the Court of Common Pleas allows me to contextualize the rich detail that litigants provided in this court. The method employed here also permits me to push on the boundaries of our understandings of social expectations of violence that are tantalizingly suggested in my smaller sample of cases. Finally, the quantitative analysis in this chapter reinforces the qualitative conclusions I suggested earlier in the dissertation, namely that gender, occupation, and status influenced the amount of damages requested and that the cases that came before the Court of Common Pleas suggest that through litigation members of late medieval society negotiated concepts of licit and illicit violence with the crown and with one another. Expanding my original dataset of eighty-two cases over a ten-year period into a larger dataset of 892 cases spanning thirty-five years reinforces the hierarchical nature of both gender and status as lived experiences in the Middle Ages. Furthermore, an examination of these 974 cases scattered throughout the fifteenth-century, reveals that litigants continued to use the court for certain aims, such as forcing or enforcing arbitration, as well as to negotiate over licit and illicit violence. 


\section{Gender Analysis}

When examining the eighty-two cases before the Court of Common Pleas between 1405

and 1415, twenty-two cases (or twenty-six percent) had women as either plaintiffs or defendants.

When considering Mackman and Steven's “Common Pleas” dataset, 212 cases (or twenty-one

percent) met the same criteria of women involved. ${ }^{17}$ This suggests that the involvement of

women before this court remained relatively stable throughout the fifteenth century. When

women appeared, it was most often as a plaintiff and/or victim of a wrong, rather than as a

perpetrator. Although as Figures 2 and 3 indicate, while there was a larger difference in raw

numbers, the difference in percentages was not as large. Women accounted for less than twelve

percent of litigants, thus supporting the fact they were a marginalized group before the law. ${ }^{18}$

However, because married women had to sue alongside their husbands, this statistic may not

faithfully represent the active litigants of the cases. Of all the torts classified under trespass vi et

armis, the most common to appear in the records was theft. It is perhaps not surprising to learn

that women were most often involved in cases of theft, when compared with the other torts under

trespass actions, as were men. ${ }^{19}$ However, over half of these cases involved instances of assault

\footnotetext{
${ }^{17}$ While his book mostly covers the sixteenth century, Tim Stretton found similar percentages: twenty-five percent of cases in Chancery Court had female litigants and 12.4 percent of cases in the Court of Requests had female litigants. Tim Stretton, Women Waging law in Elizabethan England (Cambridge: Cambridge University Press, 2005), 38-39. According to Matthew Frank Stevens, roughly twenty-five percent of cases had women as litigants in the fourteenth century, while that number had decreased to fifteen percent by the middle of the fifteenth century. "London Women, the Courts, and the 'Golden Age'," 80-81. This is also similar to percentages found for women appearing in other courts. In Chancery, for example, Anna Dronzek found seventeen percent of cases included women as litigants. Anna Dronzek, "Women and Property Conflicts in late Medieval England," in Women and Wealth in Late Medieval Europe, ed. Theresa Earenfight (New York: Palgrave Macmillan, 2010), 191.

${ }^{18}$ Out of eighty-two case dataset, there were 28 female litigants out of 235 total litigants (11.91 percent). Out of the 974 case dataset, there were 248 female litigants out of 2708 total (9.16 percent).

${ }^{19}$ As Garthine Walker shows in her work on women and theft, it was a common category of felony or misdemeanor. Further, her research in the sixteenth century shows that men outnumbered women in this offense: men accounted for eighty-two percent, while women only accounted for eighteen percent. She does not find evidence that women stole goods of less value more often than men. Garthine Walker, "Women, Theft and the World of Stolen Goods," in Women, Crime and the Courts in Early Modern England, ed. Jennifer Kermode, and Garthine Walker (Chapel Hill: University of North Carolina Press, 1994), 81-82, 86.
} 
as well, either alone or in conjunction with another tort.

When a woman was involved in the case as a litigant, the damages requested were lower than when it was only men, possibly reinforcing the idea that violence done to and by women was valued less than violence done to men, by men. The discrepancy in damages could also be a result of how plaintiffs made their damage calculations. If they took into account the economic status of the defendant, this would indicate that women, overall, held less property or less wealth than men. However, women were litigating violent offenses, as both plaintiffs and defendants. Standards of behavior as outlined in conduct manuals, sermons, and even literature cautioned women to be gentle, kind, nurturing, not violent, or angry, or forceful. Proscriptive literature aside, human nature reveals that anyone can be violent. Even though the socialization of women urged women towards non-violent means of confrontation, these cases show that not all women followed these codes in fifteenth-century England. ${ }^{20}$ However, women's violence was not seen the same as men's violence. As Krista Kesselring shows, women were less often accused of killing someone than men, "women were vastly over-represented amongst cold-blooded killers." ${ }^{21}$ Women assaulted men, or at least were accused of doing so. And women, in turn, were victims of assault, something not altogether surprising, but they also took men to court over those assaults.

That women could be violent and also that they had agency over aspects of their lives has been well documented. To the discussion of scholarship about women, the law, and violence presented in chapter one, I would like now to add a few more key works on agency before the

\footnotetext{
${ }^{20}$ Sara Butler discusses gendered standards of behavior, confrontation through non-violence, and violent women in her article, "The Law as a Weapon in Marital Disputes: Evidence From the Late Medieval Court of Chancery, 14241529," Journal of British Studies 43, no. 3 (2004).

${ }^{21}$ Krista J Kesselring, "Bodies of Evidence: Sex and Murder (or Gender and Homicide) in Early Modern England, c. 1500-1680,” Gender \& History 27, no. 2 (2015), 252-53.
} 
courts. In the introduction to their edited volume, Women, Agency, and the Law, Bronach Kane and Fiona Williamson highlight instances of women navigating the gendered nature of the legal system, pursuing their interests and often using their sex to their advantage. ${ }^{22}$ They also show that women, despite issues such as coverture, actively litigated over property and violence; that women could be just as savvy as litigators as men. ${ }^{23}$ Once chapter in particular, by Deborah Youngs, examines the complex social and legal system under which women from the South Welsh marches had to operate to seek recompense for wrongs. While Youngs is concerned with Star Chamber cases between 1530 and 1532, she shows that women were "informed and proficient in legal procedures." 24 To better understand these actions of assault before the Court of Common Pleas, which should shed light on understandings of violence, and the reasons why a gender analysis of these cases is useful, it is helpful to explore fifteenth-century expectations for men's and women's behaviors.

Despite proscriptive sources urging women to be peaceful and submissive and men to be more aggressive and assertive, women and men did not always live up to these gendered expectations. In the fifteenth century, many factors both influenced concepts of gender and delineated it; these include religion, marital and family relationships, and behavior. Christianity guided English values in the fifteenth century. The average person was invested in their religion: this was evident in both guild sponsorship of altars and lay demands on the liturgy. Moreover, the liturgical calendar structured lay life and time. ${ }^{25}$ One only has to remember that the four law

\footnotetext{
${ }^{22}$ Bronach Kane, and Fiona Williamson, eds. Women, Agency and the Law, 1300-1700 (London: Pickering \& Chatto, 2013), 7.

${ }^{23}$ Kane, and Williamson, Women, Agency and the Law, 1300-1700, 10.

${ }^{24}$ Deborah Youngs, "'She Hym Fresshely Folowed and Pursued': Women and Star Chamber in Early Tudor Wales," in Women, Agency and the Law, 1300-1700, ed. Bronach Kane, and Fiona Williamson (London: Pickering \& Chatto, 2013), 102.

${ }^{25}$ Eamon Duffy, The Stripping of the Altars: Traditional Religion in England, 1400-1580 (New Haven: Yale University Press, 2005), 4, 63.
} 
terms were not only named after the nearest feast day but were also designed to avoid major religious holy days, to see the influence of religion on the lives of the English. ${ }^{26}$ At this point in time, Christian teachings emphasized women as subservient to men. Women were expected to look to men to guide them in their lives; to ensure they continued on a righteous path and avoided the inherent moral weaknesses of being female. ${ }^{27}$ These religious views also affected the expected behavior of men and women and so helped reinforce gendered notions of conduct; this was both a paternalistic and patriarchal society.

Paternalism and patriarchy also influenced concepts of marriage and family life. England, especially Londoners, followed the northwestern European marriage pattern whereby roughly three-quarters of the population waited until their mid-twenties to marry for the first time. ${ }^{28}$ Not all men and women married; roughly fifteen percent stayed single, either devoting their life to religion or being unable to marry due to financial straits or family interference. ${ }^{29}$ Those who did marry often did so as a result of economic or business incentives and resulted in the newly married woman helping her husband run a shop or small business. While this might imply a degree of equality among men and women, social mores still recognized the man as the dominant marriage partner. Conduct books, such as How the Goodwife taught her daughter, explained to women that ideal behavior was to be submissive to fathers and husbands, remaining silent, and to stay in the home when possible. The father, or husband, was expected to run the house as good "governance was a crucial concept in fifteenth-century notions of appropriate social

\footnotetext{
${ }^{26}$ C.R. Cheney, and Michael Jones, A Handbook of Dates: For Students of British History (Cambridge: Cambridge University Press, 2004), 98.

${ }^{27}$ P.J.P. Goldberg, "Women," in Fifteenth-Century Attitudes: Perceptions of Society in Late Medieval England, ed. Rosemary Horrox (Cambridge: Cambridge University Press, 1994), 112, 117.

${ }^{28}$ Shannon McSheffrey, Marriage, Sex and Civic Culture in Late Medieval London (Philadelphia: University of Pennsylvania Press, 2006), 6.

${ }^{29}$ Ruth Mazo Karras, Sexuality in Medieval Europe: Doing Unto Others (New York: Routledge, 2005), 59.
} 
comportment." ${ }^{30}$ Cautionary tales, both based on real and imaginary events, warned men what would happen if they allowed their households to get out of control. Perhaps the most famous tale of out of control households and their consequences concerns the second Earl of Castlehaven, although it is from a later period. ${ }^{31}$

In addition to matters of governance which groomed obedient wives and daughters, the marriage practices of the time also limited women, in England, legally. As William Blackstone explained it, upon marriage "the very being or legal existence of the woman is suspended." 32 This was referred to in law as femme-covert; women who were single or legally operated as single were femme-sole. ${ }^{33}$ Most scholars, including Blackstone, link the development of coverture to Christianity; although one can see vestiges of Roman marriage with manus in which the woman was legally adopted by her husband's family. ${ }^{34}$ A married woman's property belonged to her husband, she could not legally bequeath it without his consent; she was not allowed to enter into contracts. However, she was also not responsible for his debts (or her own debts) or any crimes he may have committed on his own. ${ }^{35}$ Under these laws, married women were not permitted to sue, or be sued, without their husband as a co-litigant. ${ }^{36}$ Several of the trespass vi et armis cases intimate that the conflict only concerned the woman, but she appeared alongside her husband nonetheless.

Furthermore, during the fifteenth century, there was a definite gender divide in expected

\footnotetext{
${ }^{30}$ McSheffrey, Marriage, Sex, and Civic Culture in Late Medieval London, 137.

${ }^{31}$ See Cynthia B. Herrup, A House in Gross Disorder: Sex, Law, and the 2nd Earl of Castlehaven (Oxford: Oxford University Press, 2001).

32 Sir William Blackstone, Commentaries on the Laws of England: Book the First (London: Dawsons of Pall Mall, 1966), 430.

${ }^{33}$ See Marjorie Keniston McIntosh, "The Benefits and Drawbacks of Femme Sole Status in England, 1300-1630," Journal of British Studies 44, no. 3 (2005) for a more detailed examination of this.

${ }^{34}$ Jane F. Gardner, Women in Roman Law and Society (Bloomington, IN: Indiana University Press, 1986$), 86-87$.

35 J.H. Baker, An Introduction to English Legal History (Oxford: Oxford University Press, 2007), 551.

36 There were exceptions if a woman was trading as femme-sole, but as Stevens points out in his article, they were rare. Stevens, "London's Married Women," 116-118.
} 
or accepted behavior. As previously mentioned, women were tied more to their sexual and marital status for their good reputations than men were, and this was a time when reputations meant a great deal. ${ }^{37}$ Men were also conditioned to be more violent than women. A woman with a tarnished reputation was not supposed to resort to violence, whereas men were expected to. Rather than changing the violent nature of men, people sought to channel it. ${ }^{38}$ Indeed, many thought violence could contribute to social order by correcting servants' or apprentices' behavior, by correcting a wife's or child's behavior, or by punishing convicted felons. Even this type of violence was not wholeheartedly accepted: violence out of anger, beatings that resulted in death or permanent harm, or even drawing blood were all considered illicit. ${ }^{39}$ Women who beat their husbands were dealt with harshly by the law; indeed, women who committed violent acts, such as mariticide or infanticide, did not fare well before the law. ${ }^{40}$ Yet, the Court of Common Pleas records suggests that within these strictures, men and women navigated a wide array of violent acts with less punitive outcomes.

More often than not, women were the victims of violent acts. Out of 119 torts from the smaller dataset from the start of the fifteenth century, women were accused of perpetrating the action in only twenty-two of the torts, whereas they were victims in thirty-two instances. This percentage does not change when including cases from Mackman and Stevens's "Common Pleas" dataset (see Figures 2 and 3). With 1,528 torts, women were accused of perpetrating only

\footnotetext{
${ }^{37}$ I discuss this in chapter one.

${ }^{38}$ Warren C Brown, Violence in Medieval Europe (Harlow, UK: Pearson Education Limited, 2011); Richard Kaeuper, Chivalry and Violence in Medieval Europe (Oxford: Oxford University Press, 1999); Hannah Skoda, Medieval Violence: Physical Brutality in Northern France, 1270-1330 (Oxford: Oxford University Press, 2013). See the previous discussion about violence in chapters one and four.

${ }^{39}$ Skoda, Medieval Violence, 193-231.

${ }^{40}$ Infanticide accusations were rare in the fifteenth century, but as Garthine Walker explains, they caused enough concern by the seventeenth century that a law was enacted concerning it. Skoda, Medieval Violence, 228; Garthine Walker, "Homicide, Gender, and Justice," in Crime, Gender and Social Order in Early Modern England (Cambridge: Cambridge University Press, 2003), 136, 140-141, 148.
} 
136, where as they were the alleged victims in 200 instances. ${ }^{41}$ Women represent only a fraction of those involved in violent acts, even as victims. Women were equally represented, when compared against women, across the torts. For example, sixty-four of the 144 abductions were of women, seventy-two of the 336 assaults were against women, and women were the victims in sixty-eight of the 600 instances of theft. However, when looked at proportionally, women were more likely to be victims of abduction, voluntarily or involuntarily as the case may be, than they were to be victims of assault or theft. ${ }^{42}$

Figure 2 - Breakdown of Litigants by Gender, 1405-1415

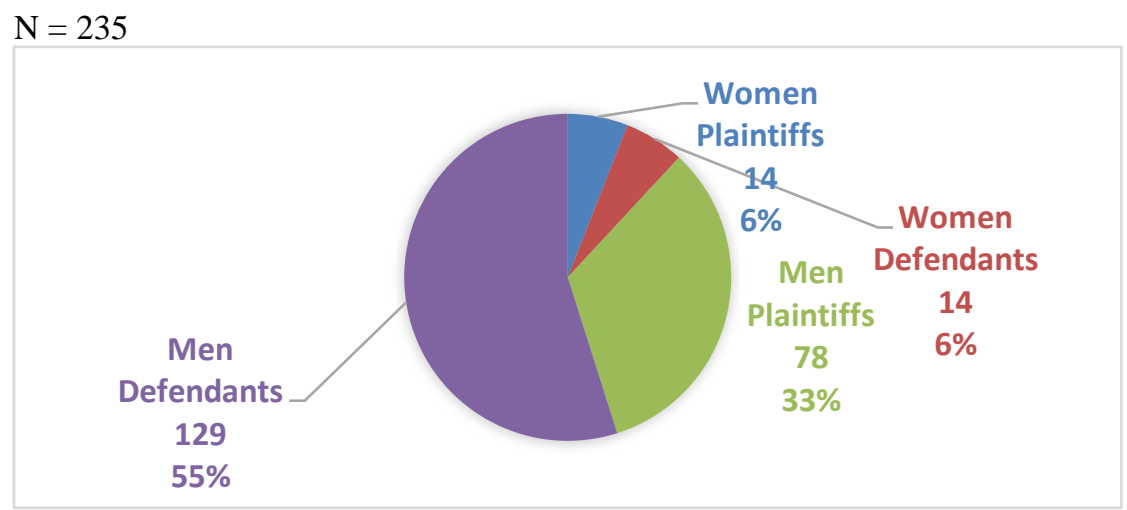

*There were 235 total plaintiffs and defendants in the eighty-two case dataset. This figure has a different total than mentioned above because some cases had both female plaintiffs and female defendants.

\footnotetext{
${ }^{41}$ There is a discrepancy in the number of cases versus the number of torts as one case could have multiple torts listed.

${ }^{42}$ Caroline Dunn, Stolen Women in Medieval England: Rape, Abduction, and Adultery, 1100-1500 (Cambridge: Cambridge University Press, 2012). for more on abduction of women both against their will and with their consent.
} 


\section{Figure 3 - Breakdown of Litigants by Gender, 1400-1500}

$\mathrm{N}=2708$

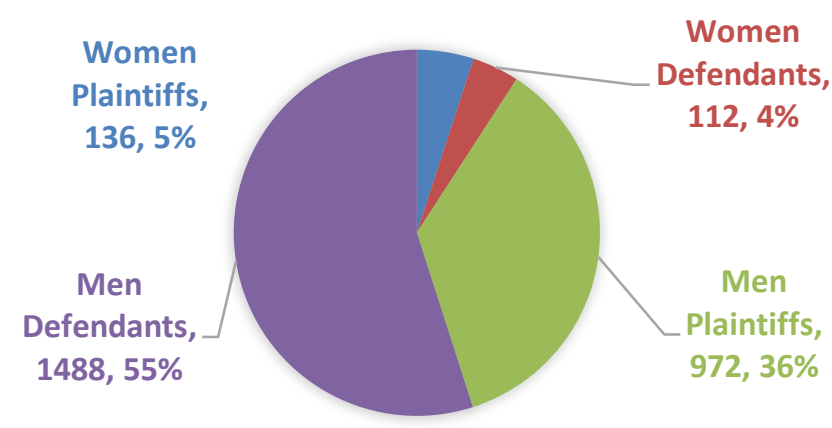

*There were 2,708 total plaintiffs and defendants in the 974 case dataset. This figure has a different total than mentioned above because some cases had both female plaintiffs and female defendants.

Unfortunately for female victims, the records make it difficult to underwent how much violence was directed towards women (see Figure 4). Fifty-six women appeared as the sole plaintiff in the case, whereas eighty appeared alongside men; and in sixty-four cases women appeared as victims in litigation between only male plaintiffs and defendants; this was a total of 200 cases in which women appeared. Seventy-six sued with their husbands as the law required them to, while four women were listed as plaintiffs alongside men who were not obviously related to them. ${ }^{43}$ For example, Alice Goshaline sued over the theft of her late husband's goods along with the other executors of his will. ${ }^{44}$ These cases are prime examples of how legal sources can gloss over women and violence. In cases concerning multiple torts, such as theft and assault, there was no indication from the plaintiffs who was doing what during the violent event. When Elizabeth Mowbray sued John and Idonea Sutton for assault, housebreaking, and theft she did not describe in her count whether John Sutton had assaulted her servant while Idonea Sutton stole the goods, or if it was the reverse, or if both equally participated. ${ }^{45}$ In forty-eight of the

\footnotetext{
${ }^{43}$ While they could have been unrelated, it is possible that the woman was a widow using her husband's surname and the men could have been her own male blood relatives.

44 TNA, CP 40/599, rot. 548.

45 TNA, CP 40/560, rot. 116.
} 
seventy-six cases in which a wife and husband sued, the violent action was directed only towards the woman. For instance, Christopher and Amlane Nicolas sued Simon Bisshoptre for assaulting Amlane before she married. ${ }^{46}$ The husband was listed was only because the law required the case to include him. If we take the cases where spouses sued jointly and where men sued other men over a violent act directed at a woman, women would have been the sole victim and sole plaintiff in 168 of the cases (out of 200 total as outline above). What happens when we change these parameters represents quite a statistical leap, from 5.7 percent of women as the sole plaintiff, a number that severely undermines the idea of women litigating violent acts, to 17.2 percent. While seventeen percent is still not high, it gives a more accurate representation of women before the courts.

\section{Figure 4 - Women Appearing in the Common Pleas}

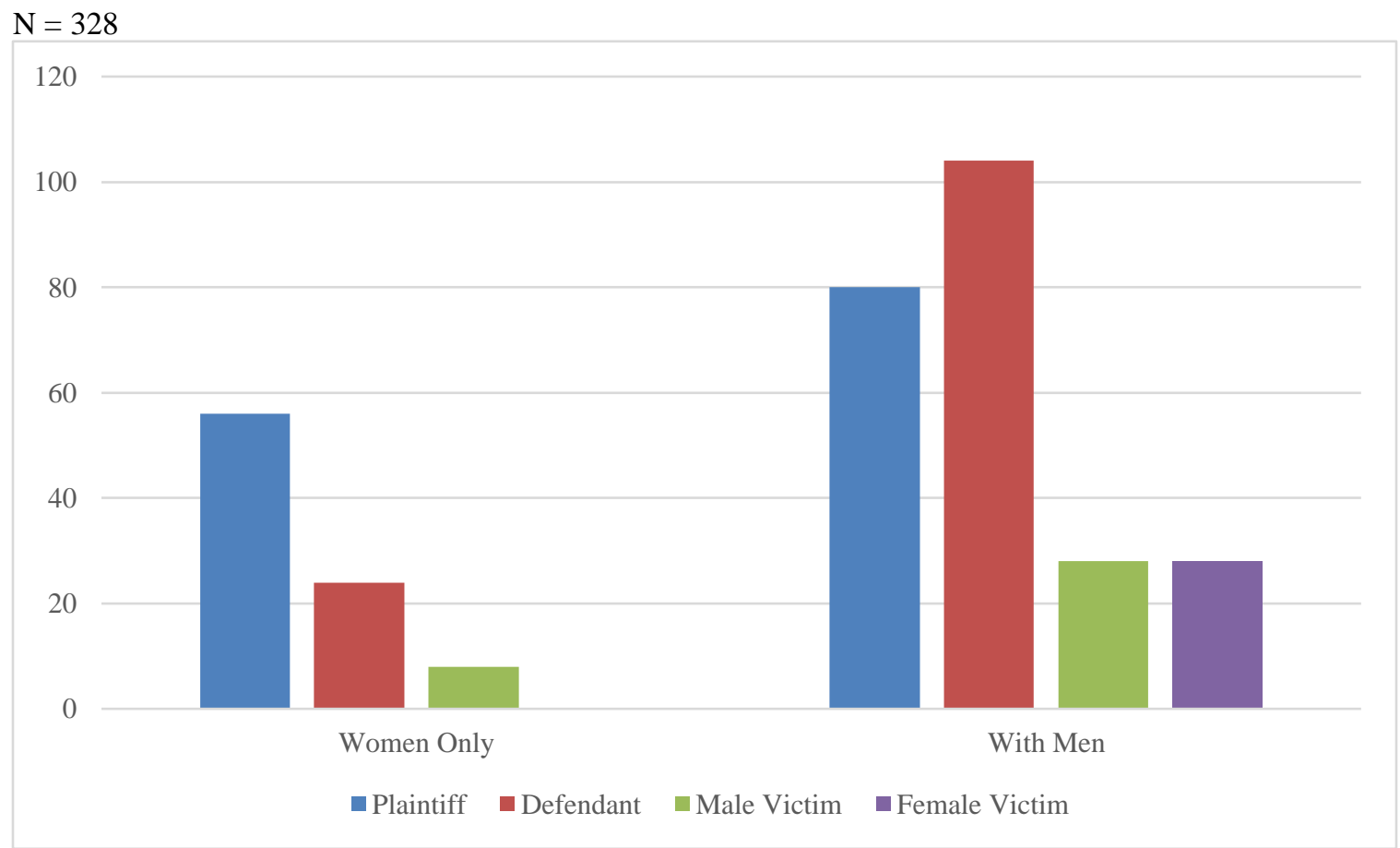

*This figure represents women acting alone and women acting alongside men, either as plaintiffs or defendants. It also represents the sex of the victims in those cases of assault, imprisonment, or abduction.

${ }^{46}$ TNA, CP 40/951, rot. 358. 
Women could also perpetrate violence, as the Breynton v. Phillip case from the beginning of this chapter illustrates. Women were defendants in 112 cases of the 974 cases enrolled between 1400 and 1500 (eleven percent), representing roughly seven percent of all defendants (out of 1600 defendants total). These numbers are reflective of societal norms that women were expected to behave less violently than men. Alternatively, this data could also suggest that women's violence was addressed within families more often than inside of the courts. While women were more frequently listed alongside male defendants, at least twenty women appeared as sole defendants. The majority of these women were accused of theft rather than assault, abduction, or imprisonment. However, Eleanor Phillips was not an anomaly among these cases. For example, in a case from 1404, Joan Williamservant Bole, the sole plaintiff, was accused of abducting John Grigge, the servant of John Chivaler. ${ }^{47}$ Some might question how a lone woman assaults and kidnaps a man; the fact that these cases not only were pursued in the Court of Common Pleas, but in the Phillip's case also came to a conclusion, illustrate that women perpetrated violence despite proscriptive norms.

47 TNA, CP 40/579, rot. 290. 
Figure 5 - Breakdown of Average Damage Requests in Pounds by Torts, Separated by Cases Which Include Women and Cases Which Only Include Men

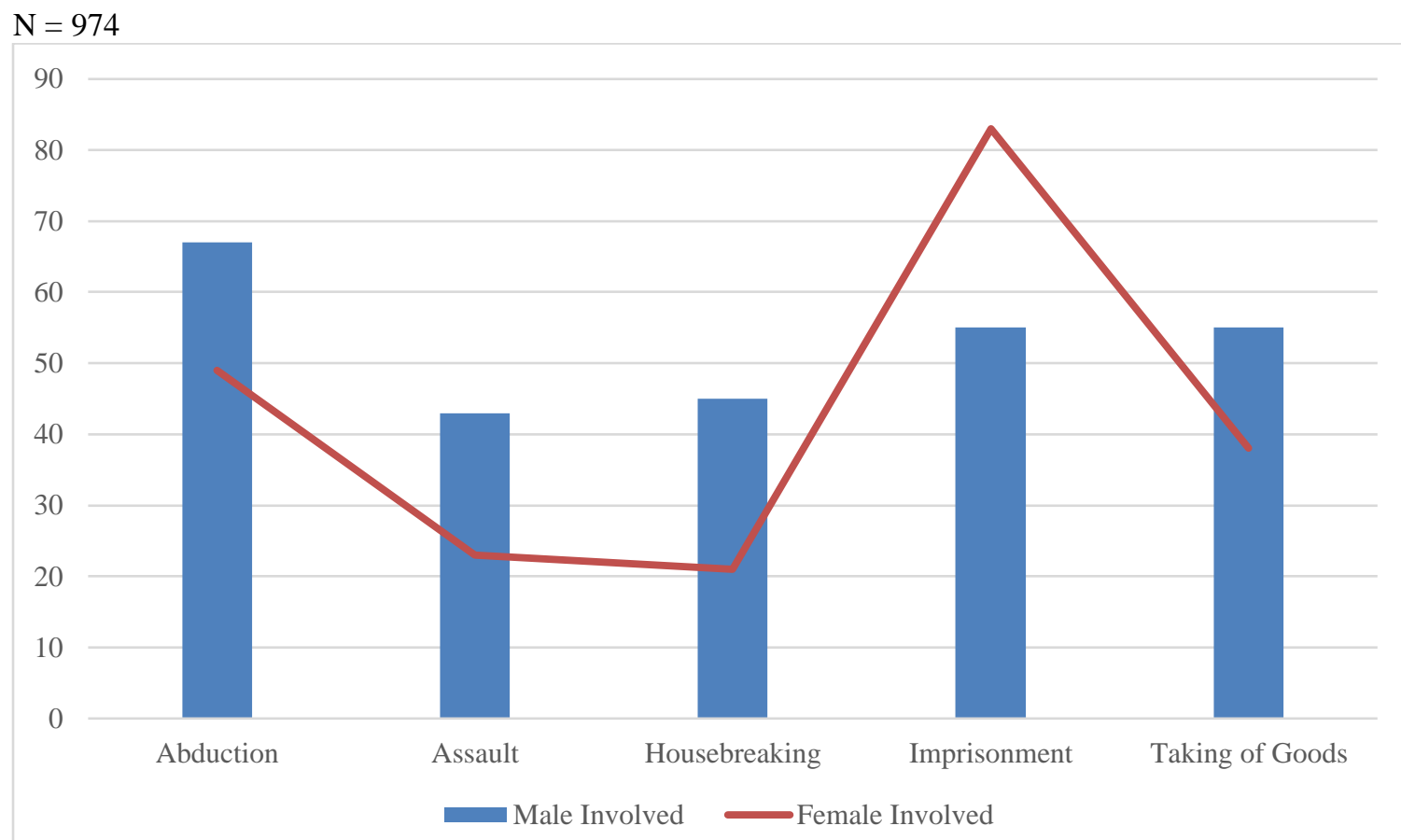

*This figure represents the variations in damage requests in pounds as broken down by tort. The blue represents average damage amounts requested in male-only litigation, while the red line represents average damage amounts for cases in which a woman was involved as either a plaintiff or defendant. Results based on 1400-1500 dataset of 974 cases.

Regardless of what capacity in which they appeared in these records, on average across this sample, violence done to and by women was valued less than that done to and by men. The amount of damages varied based on the type of tort, but in general and across both datasets, cases in which women were involved saw plaintiffs request damages twenty-five percent lower than those cases which only involved men. When I break down the damage requests by tort, the differences between men-only and women-included increase (see Figure 5). As mentioned previously, damage requests in instances of assault involving women (either as perpetrators or victims) were forty-seven percent less than men-only, on average. However, housebreaking had the highest percentage difference between genders at fifty-four percent less in damages for women-included verses men-only torts. A detailed analysis of the types of goods taken might 
help explain this gap, although a general breakdown of cases show that thefts with women seem to have involved household goods, while male-only thefts included more livestock, weapons, and building supplies. ${ }^{48}$ A significant difference exists in the damages for imprisonment in which the average for cases with women was eighty-three pounds, while men-only cases had an average of fifty-five pounds in requested in damages. Cases in both categories, men-only and women-only, contained one high amount of damages, 300 pounds, but there was nothing in the female cases that suggested why there might be such disparate numbers. This might be related to how men and women were economically valued, relatively speaking, or the economic worth of the litigants. The loss of women's economic contribution is most likely viewed less than the loss of men's potential economic earnings.

\section{Status Analysis}

Urban environments created unique places in which members of a variety of social statuses could interact with one another. While London stood out among the other English towns as the largest, even smaller cities like York or Bristol operated along similar social and political lines, illustrating that while larger London was not unique as an urban environment. Within the streets of a city, one might find noblemen moving alongside, and interacting with, merchants and craftsmen. Along those same streets, servants went about the business of their masters, buying and selling goods at markets across the city. Even in the fifteenth century, socio-economic status was a complex construct encompassing political, economic, and cultural distinctions. In England, the various social statuses were also more flexible than on the continent, particularly France. While historians continue to debate exactly who made up the aristocracy, as well as who belonged in merchant, artisan or other lower-status categories, for this dissertation, I use the

\footnotetext{
48 This supports findings reported by Garthine Walker in "Women, Theft and the World of Stolen Goods," 88.
} 
labels of status and occupation to distinguish between those given a title, such as gentleman, and those given an occupation, like barber, within the records of the Court of Common Pleas. ${ }^{49}$

For occupations, I included all types of merchant and artisan trades, but I also included members of the clergy and those identified as husbandmen. In terms of status, I included not only titled nobility, such as earls or duchesses, but also yeoman, esquires, gentlemen, and knights. ${ }^{50}$ For this part of the chapter, I undertook two separate analyses. In my dissertation data, there were not enough occupations or statuses listed for defendants to allow for a distinct categorization. ${ }^{51}$ When including Mackman and Stevens's "Common Pleas" data, there was a significant difference. Therefore, I considered them separately. The results were only marginally different: when status and/or occupation was listed, the damages requested were twenty percent higher than when none were provided. However, there was only an eleven percent difference, with occupation having an overall higher percentage than status. The analysis of these records reinforces the idea of the main urban social hierarchies in place at the time in which economic status was not necessarily outranked by landholding and titles, at least in terms of damages.

The Court of Common Pleas was more accessible to the average Londoner than to people who lived further afield from Westminster. However, this does not mean the court was widely used by all statuses. This is especially true when examining plaintiffs, as defendants had no say in court in which they found themselves. As previously mentioned, the court cost a fair amount of money to access: at least seven shillings to obtain an original writ from the Court of Chancery,

\footnotetext{
${ }^{49}$ Kate Mertes, “Aristocracy,” in Fifteenth-Century Attitudes: Perceptions of Society in Late Medieval England, ed. Rosemary Horrox (Cambridge: Cambridge University Press, 1994), 44-45; D.M. Palliser, "Urban Society," in Fifteenth-Century Attitudes: Perceptions of Society in Late Medieval England, ed. Rosemary Horrox (Cambridge: Cambridge University Press, 1994), 136-37.

${ }^{50}$ I made the distinction between husbandmen and yeoman as a result of Christopher Dyer. As he shows, yeoman not only held more land than a husbandman would, but also more often employed laborers to work that land. See Christopher Dyer, Making a Living in the Middle Ages: The People of Britain, 850-1520 (New Haven: Yale University Press, 2002), 358.

${ }^{51}$ See Table 7 on page 222.
} 
if the plaintiff asked for the lowest possible amount of damages. ${ }^{52}$ It is unlikely that a prominent Londoner would have chosen the Court of Common Pleas to pursue a dispute against someone of the lowest socio-economic status; arbitration was a much more likely and less expensive option, and there were always the local London courts. ${ }^{53}$ However, the local courts were extremely busy and most of the people in this court, even the defendants, were at least in the middle of the socioeconomic ladder of urban life. When examining the records after 1413 and the new Statute of Additions, one sees a variety of occupations, from butchers, carters, cordwainers to merchants, fishmongers, and ironmongers. ${ }^{54}$

In fifteenth-century English society, those who obtained their wealth from landholding were considered more 'worthy' than those who had to work for a living. ${ }^{55}$ However, having a title, or not having to engage in trade as the case may be, did not necessarily outweigh economic status in London. For example, in theory, the Mayor of London was second only to the king within the walls of the city, outranking even a duke in terms of precedence. ${ }^{56}$ These socioeconomic hierarchies were not without contestation, but the landholders ran both rural and national politics. Among them, there was a social hierarchy which included all of the English, Scottish, and Irish peerage into the landed gentry down to the knights, esquires, and gentlemen. This last, gentlemen, was the second most common status identification to make it into the Court of Common Pleas records. ${ }^{57}$ Outside of the Court of Common Pleas, the men and women who belonged to the nobility or gentry wielded great power, but within the Court of Common Pleas,

\footnotetext{
52 I discuss the cost of the court in chapter two.

${ }^{53}$ Edward Powell, "Arbitration and the Law in England in the Late Middle Ages (The Alexander Prize Essay)," Transactions of the Royal Historical Society 33 (1983), 58-60.

54 The first three occupations, while potentially prosperous, were not usually in the same status of earnings as the second three occupations.

55 Mertes, "Aristocracy," 50.

${ }^{56}$ Caroline M. Barron, London in the Later Middle Ages: Government and People, 1200-1500 (Oxford: Oxford University Press, 2004), 156-57.

${ }^{57}$ Citizen was the most common status but is likely because my dataset was London focused.
} 
they contended with another group used to money and power: the urban elite.

Within London, the highest economic and political status was the freeman, or citizens: those admitted to the freedom of the city. By the fifteenth century, this was a highly guarded privilege. ${ }^{58}$ Leading London citizenry would have been merchants, which mostly meant those involved in wholesale goods, some artisans and gentry, those who did not make their living through commerce. ${ }^{59}$ These citizens were the most common status identified in the Court of Common Pleas. ${ }^{60}$ "Citizen” was considered a separate status, not held by all Londoners, although for statistical purposes, I excluded it and only used the occupations also listed. Professional occupations such as attorney or scribes are under the occupation classification. Litigants who did not have a status noted in the case alongside their occupation were classified under occupation only as I could not assume they were also citizens or of any other status. Citizens also ran both the city government and the various guilds and companies in the city. While each man admitted to the freedom of the city took the same oath of citizenship, representing an idea of a common civic identity, there was a hierarchy among citizens with those holding civic offices having a higher status than a common citizen. ${ }^{61}$ Among these merchant and artisan guilds existed disputes over relative power within the city as well. Wealth was more important than an occupation for most people living in towns; for example a merchant as an occupation would have been considered one of the elites of the city, but if that merchant earned less than, say, a tailor the merchant might be considered lower than the tailor. ${ }^{62}$ Despite this focus on wealth, there existed a general hierarchy of craft and merchant guilds within the city; merchant guilds, by and large,

\footnotetext{
${ }^{58}$ Barron, London in the Later Middle Ages, 204.

${ }^{59}$ Palliser, "Urban Society," 140.

60208 men were designated as citizens, while only 128 were listed as gentlemen.

${ }^{61}$ Christian D. Liddy, Contesting the City (Oxford: Oxford University Press, 2017), 30-31.

62 This mostly had to do with who was able to pay the requisite city taxes and support the city financially. Palliser, "Urban Society," 141; Liddy, Contesting the City, 29.
} 
overshadowed the craft guilds. ${ }^{63}$ However, throughout the fifteenth century, there was an influx of immigrants into London, which caused certain craft companies to rise in power, rivaling the merchant guilds in economic clout. ${ }^{64}$

Socio-economic tensions also existed within the guilds. Guilds were often broken down into liverymen, masters, yeoman, journeymen, and apprentices. Journeymen fraternities could either be welcomed as a part of the overall guild, to avoid tension, or they formed as organizations outside the guild. ${ }^{65}$ These groups often caused tension in the city, especially when protesting poor treatment by the liverymen and masters of their guilds, to the point where the mayor and others told them to disband, refused to recognize them as official guilds, and pushed them to listen to the masters of the true guild and/or their employers. Often, these groups reintegrated into the larger guild, but only after concessions, which indicates that they had valid complaints about their treatment. The highest members of a guild were the liverymen, so called because of the distinct company livery they were permitted to wear. These were the men who controlled not only the craft but the city as well. As a result of this hierarchy within the guilds, it can be difficult to ascertain from the records of the Court of Common Pleas just where a person might fit within the guild system. Some of the cases feature disputes over apprentices and servants among those higher on the socio-economic ladder.

Unfortunately, ascertaining what role status and occupation played in the amount of damages is quite difficult before 1413. For the eighty-two cases of my dissertation dataset, twenty-two out of seventy-eight male plaintiffs had an occupation listed (twenty-eight percent). Of those, only six were explicitly labeled as citizens of London. Sixty-three male defendants, out

\footnotetext{
63 Palliser, "Urban Society," 141.

${ }^{64}$ For example, while mercers and fishmongers may have dominated aldermen elections in the 1300 s, by the $1500 \mathrm{~s}$ merchant tailors and haberdashers were on the rise. Barron, London in the Later Middle Ages, 230.

${ }^{65}$ Barron, London in the Later Middle Ages, 212.
} 
of 129, had occupations listed (forty-nine percent); only four were labeled as citizens. ${ }^{66}$ That the clerk of the court did not include 'citizen' when describing those with occupations does not mean they were without that privilege; they could have not expressed it in court, the clerk may not have thought to notate it, or the clerk simply missed adding their status in. Because there were a variety of reasons why this might be missing, I do not want to place too strong an emphasis on the low numbers of London citizens in court. Only twenty-eight, out of 509 people, had a status listed (5.5 percent); fifteen of those were citizens. If I narrow the field down to only plaintiffs and defendants, the numbers become even smaller. For this reason, I calculated statistics for my dissertation dataset without distinguishing between status and occupation.

Even without examining status and occupation separately, the data demonstrates that having either listed affected how much money was requested in damages. On average, the damages requested were eighteen percent higher when either status or occupation was included in the case. As I calculated this data, if there was a status or occupation listed for either the plaintiff or defendant, the numbers suggest that when deciding on what to ask for in damages both the plaintiff's economic circumstances as well as that of the defendant was taken into account. Moreover, the value of the injury, whether that was stolen goods or loss of services or physical harm, further influenced this valuation. To what extent any of these factors might have influenced a plaintiff in their damage requests is difficult to ascertain based on the records. For example, in 1408, Elizabeth Beauchamp requested 400 pounds in damages in her case against John and Joan Scardeburgh; however, no occupations or statuses were listed, so it would seem the damages were based solely on the number of furs and specialty cloths allegedly stolen by the pair. ${ }^{67}$ On the other hand, two goldsmiths went to court in 1407: Richard Ede accused Hans

\footnotetext{
${ }^{66}$ No women had occupations listed for them in the records.

67 TNA, CP 40/590, rot. 328. The goods in this case were valued at 236 pounds, thirteen shillings, and four pence.
} 
Inkhorne of stealing 120 pounds of jewelry and other items of his trade, but he requested 500 pounds in damages. This may illustrate that while the value of the goods was a factor, the potential loss to his business in terms of future revenue in addition to Inkhorne's business earnings were also larger components in the damage request. ${ }^{68}$

Figure 6 - Number of Litigants with Status or Occupation Listed

$\mathrm{N}=92$ (blue)

$\mathrm{N}=1436$ (red)

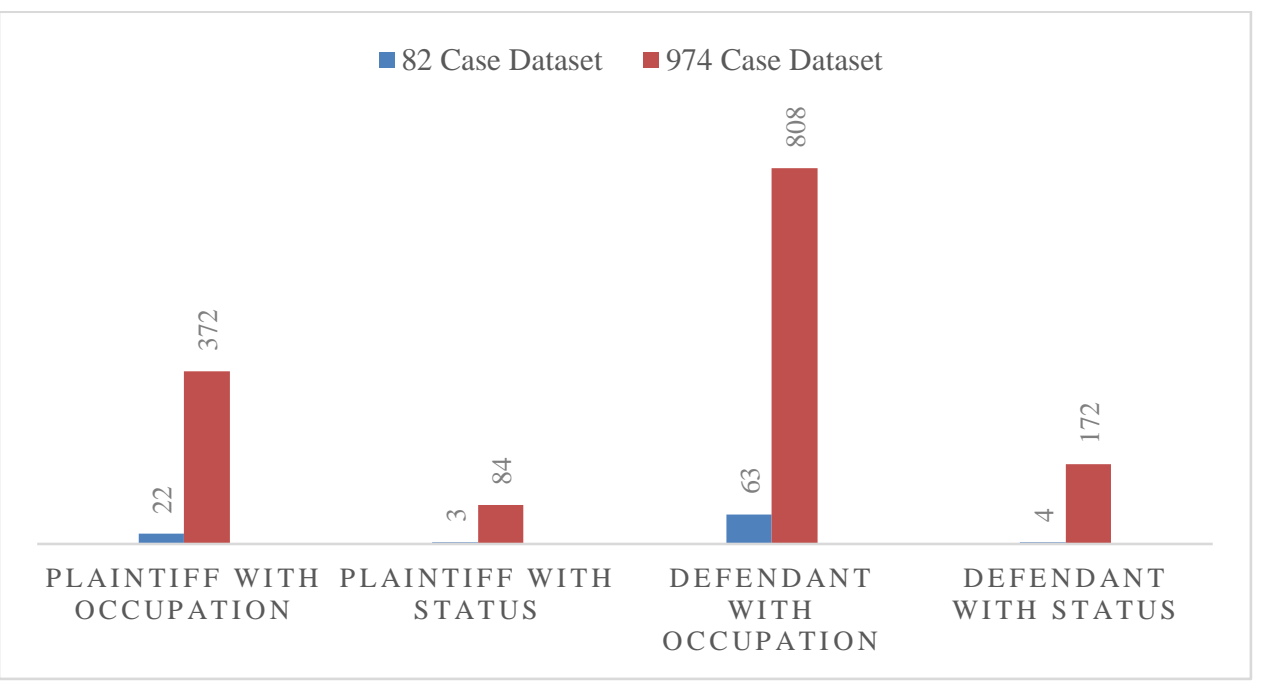

*This figure represents the number of plaintiffs and defendants who had a status or occupation listed in the records. The blue represents the dataset from 1405-1415 and is out of 235 total litigants. The red represents the larger dataset from 1400-1500 and is out of 2708 total litigants.

The Mackman and Stevens's "Common Pleas" dataset, which for calculation purposes also include my dissertation data, reinforces these notions that status and occupation increased the amount of damages requested on average across all the cases. The dataset also indicates that status was not as important as occupation when requesting damages. Overall, plaintiffs requested, on average, fifty pounds when status or occupation was listed in the court case and only thirty-nine pounds, on average, when it was not provided. This was twenty-two percent less in damages when there was neither status nor occupation listed for any of the litigants. However,

${ }^{68}$ TNA, CP 40/585, rot. 106. 
when I further break down the data between occupation and status, the numbers change slightly and in interesting ways. Examining cases in which litigants were identified by status without reference to an occupation shows that plaintiffs asked for, on average, forty-three pounds; while plaintiffs in cases in which litigants were identified by occupations rather than status, requested an average of forty-eight pounds in damages. Of course, there were more cases in which occupations appeared, but that is still an eleven percent difference in damage requests. As the majority of litigants appearing in the cases were identified as Londoners, this suggests the idea that, in an urban environment, occupation was more important than status. For both sets of categories, the lowest amount of damages requested was five pounds. In terms of cases with litigants identified by status, the highest amount of damages requested was 200 pounds, which occurred in three cases; only one case that included occupations for the litigants had a very high amount of damages requested. ${ }^{69}$ This was the case of Nyweport $v$. Ulmis discussed in detail in chapter four, in which Nyweport requested 1000 marks for the theft of bonds and the abduction of his servant. ${ }^{70}$ This data suggests that occupation, or perhaps the potential economic loss to tradesmen as a result of a violent act, weighed more heavily on the decision of damages than status.

${ }^{69}$ TNA, CP 40/579, rot. 304d; TNA, CP 40/585, rot. 210; TNA, CP 40/603, rot. 566.

70 TNA, CP 40/601, rot. 139. 
Figure 7 - Average Amount of Damage Requests in Pounds in Cases Listing Status and Occupation

$\mathrm{N}=92$ (blue)

$\mathrm{N}=1436$ (red)

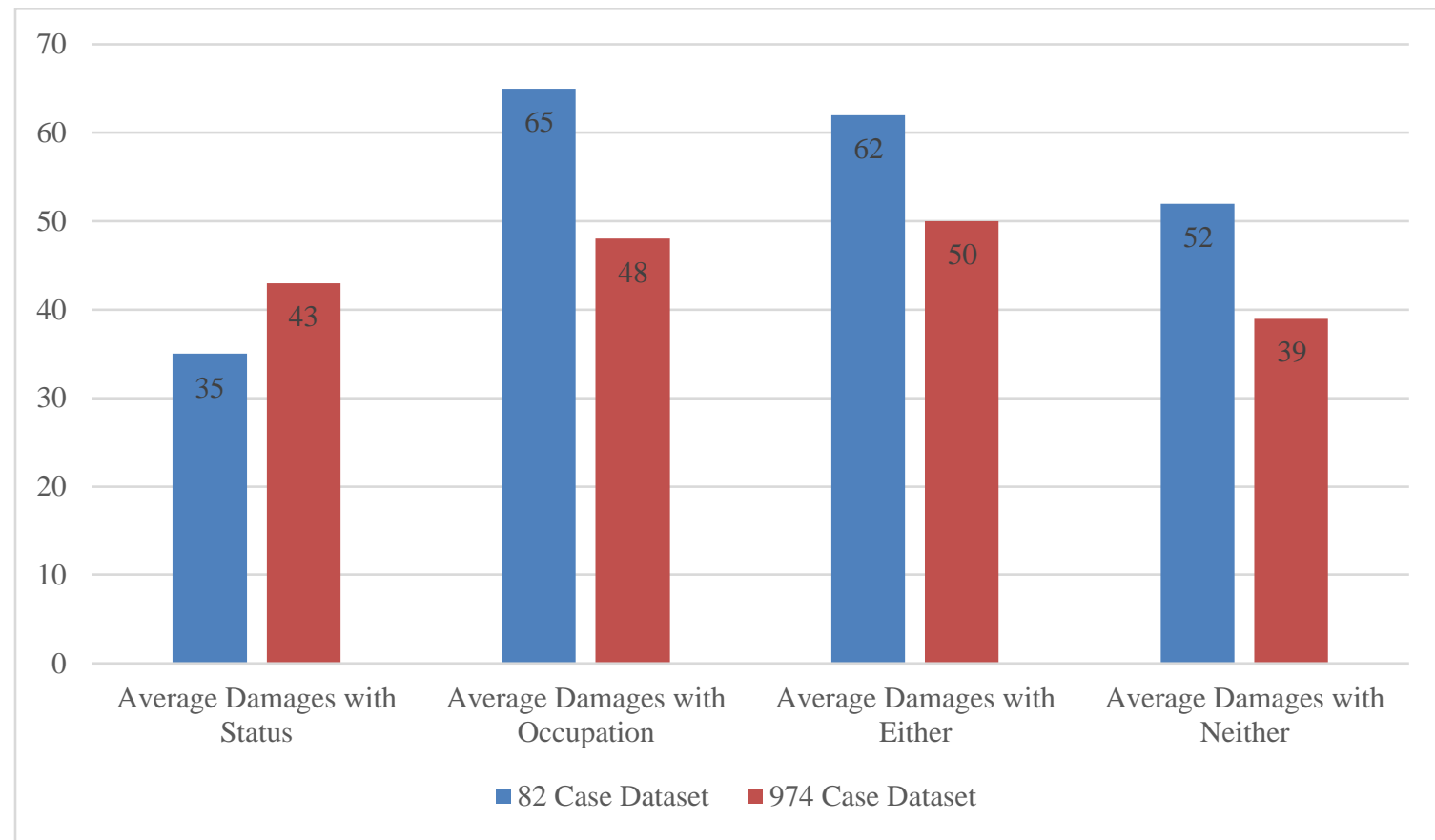

*This figure represents the average amount in pounds for damage requests. The blue represents the dataset from 1405-1415. The red represents the larger dataset from 1400-1500

\section{Defense Analysis}

Throughout this dissertation, the main argument has been that through examining court records, and those of the Court of Common Pleas in particular, one can see the ways in which members of society used the courts to pursue their agendas, in some instances manipulating the system, and in others using the courts to negotiate concepts of licit and illicit violence between themselves and with the crown. Examining the cases of my dissertation dataset shows how trespass vi et armis was more than a legal fiction, but a way to understand how plaintiffs and defendants described both order and disorder, and that this was a distinct strategy before the court. Using Mackman and Stevens's “Common Pleas” dataset allows me to see whether these notions changed over time. Of the several categories of defenses I noted in the database, three 
best highlight idea of savvy litigants and how men and women dealt with violent acts. I discussed these earlier in the chapter, but the full list of defense categories was: self-defense, prior arbitration, alibi, quitclaim, self-help, and technicalities. In this last category belong challenges to the validity of the writ itself, such as errors in spelling, valuation of goods, geographic errors, and challenges of possession; all of these would have been grounds for dismissal of the case if proven valid.

The three best for conceptualizations of violence, however, are arbitration, self-defense, and self-help. Arbitration, a common occurrence both before and during litigation, signifies that not all violence warranted court action in fifteenth-century England. When someone was reluctant to arbitrate, initiating a lawsuit could encourage them to the bargaining table, as it were. ${ }^{71}$ Likewise, defendants claiming prior arbitration show that some violence could be negotiated at the private level rather than in open court. Across the fifteenth century in the Court of Common Pleas records, defending oneself from an assault was just as popular a defense as claiming prior arbitration. In these cases, defendants admitted to the violence but claimed it was legitimate because they were defending themselves or restoring the peace. Finally, in this section, I also examine cases in which defendants claimed to be remedying a wrong (violent or otherwise) done to them without recourse to the law. While there was room for this type of defense in the early fifteenth century, by the end of the century, it seems society had decided to stop accepting it as a legitimate use of violence.

The number of defendants who claimed prior arbitration or self-defense did not vary significantly over the years. People involved in violent acts who might have arbitrated their case before it went to court suggest that not all violence needed to be litigated, at least not at first.

\footnotetext{
${ }^{71}$ See Powell, “Arbitration and the Law.” for information about this in general, but more specifically pages 55-56.
} 
Arbitrating first, if successful, would have helped both parties financially. References to arbitration in these cases indicates that violence continued to be negotiated between individuals outside of court. In addition, that self-defense as a special issue pleading in assault cases remained at a somewhat constant level throughout the sample of cases indicates that this was viewed as licit violence, and that society was not willing to yield it to the king's justice. However, most telling about the changing ideas of licit and illicit violence were the number of defendants who provided a defense narrative that I could classify as self-help. While those defendants who described their actions as self-help never represented a majority of the cases, there were enough at the beginning of the fifteenth century to suggest that this was not considered an illicit use of violence in the early years of the dataset. By the end of the century, these types of defenses had disappeared completely. In fact, not one defendant described their actions as self-help in the last fifty years of the fifteenth century, according to Mackman and Stevens's “Common Pleas" dataset.

\section{Table 6 - Breakdown of Cases by Defense Pleading}

\begin{tabular}{|l|l|l|l|l|}
\hline Type of Defenses & 82 Case Dataset & Percentage & 974 Case Dataset & Percentage \\
\hline Not Guilty & 40 & $49 \%$ & 548 & $56 \%$ \\
\hline Arbitration & 10 & $12 \%$ & 157 & $16 \%$ \\
\hline Self-Defense & 10 & $12 \%$ & 141 & $14 \%$ \\
\hline Self-Help & 4 & $5 \%$ & 47 & $5 \%$ \\
\hline Others & 18 & $22 \%$ & 80 & $8 \%$ \\
\hline
\end{tabular}

Claiming prior arbitration was used throughout the early fifteenth century by defendants before the Court of Common Pleas. Arbitrating one's differences was a common occurrence; it saved would-be litigants the costs of going to court and allowed the parties involved to restore or retain their good-standing in the community. However, potential problems could arise when either party refused to abide by the terms. When this happened, the issue was usually escalated to court. In my dissertation dataset, ten defendants, out of eighty-two cases, claimed prior 
arbitration in their defenses. ${ }^{72}$ Examining these cases allows one to see the nuances in how society dealt with violence; court was not always the first resort. These cases are a strong indicator that individuals preferred to deal with violence without crown interference but used the courts when necessary. In arbitration, the most common item exchanged to rectify the situation was a gallon of wine, although other arbitrators assigned monetary compensation in addition to or instead of the wine. ${ }^{73}$ For the most part, plaintiffs denied the claims that they had engaged in prior arbitration and argued their suits should move forward. Sometimes this was a blanket denial; while other times it was a denial that the arbitration was about the subject of the current lawsuit, but that it was over some other issue. ${ }^{74}$ This second type of counter claim once again illustrates how common arbitration was as a settlement device over violent actions.

Pleading a special issue which used prior arbitration as a defense continued throughout the fifteenth century. While none of the Mackman and Stevens's "Common Pleas" trespass vi et armis cases from 1480 or 1500 had defendants claiming prior arbitration, other writs did. ${ }^{75}$ Additionally, prior arbitration was used as a defense against accusations of violence as late as 1468. In 157 cases out of 974 (or fifteen percent) across the larger dataset, defendants used this in their pleas. While it is unclear how successful of a defense this was because we rarely see the settlement of cases (only four cases included a verdict and none were for the defendants), that it was still being used later in the century indicates that many in society still sought to self-regulate violence rather than allow the crown to do it. There was a long tradition of subjects using the

\footnotetext{
${ }^{72}$ I discussed these in more detail in chapter three.

${ }^{73}$ It was the most common item out of the ten cases in which defendants claimed prior arbitration, and as Barbara Hanawalt discusses, this was, overall, a common gift exchanged. See Barbara A. Hanawalt, Ceremony and Civility: Civic Culture in Late Medieval London (Oxford: Oxford University Press, 2017), 83-86.

74 TNA, CP 40/585, rot. 367d; TNA, CP 40/594, rot. 499; TNA, CP 40/602, rot. 171d; TNA, CP 40/606, rot. 487d; TNA, CP 40/608, rot. 305; TNA, CP 40/610, rot. 112d; TNA, CP 40/616, rot. 313d; TNA, CP 40/617, rot. 117; TNA, CP 40/617, rot. 179; TNA, CP 40/617, rot. 254.

75 These were the only two years included in Mackman and Stevens "Common Pleas" after 1468.
} 
legal process to enforce their own ideas of licit and illicit, and while the crown may have removed some of those avenues as it solidified legal structures, the people merely found different ways to maneuver around the law, common or statutory. ${ }^{76}$ They were also savvy to use legal structures to enforce arbitration. Arbitration continued to be one of those methods for individuals to negotiate violence, as did claiming self-defense.

Defending oneself also remained a relatively popular defense throughout the century when it came to cases of assault. Forty-two percent of all defendants (141 out of 336 cases), across both datasets, accused of assault used self-defense to justify why their violence was licit rather than illicit. If we narrow that down to just the dissertation dataset, thirty-one percent of defendants (ten out of thirty-two cases) in assault cases used this in their pleas. ${ }^{77}$ By using this defense, these litigants argued that regardless of laws or statutes against assault, they were within their right to defend themselves when attacked. For example, in his plea in 1412, William Ussher claimed that Thomas Perot had been the one to attack him and "he defended himself as was lawful of him." 78 Once again, it is difficult to ascertain how the rest of society might have viewed these claims, as none of those cases conclude in the records of the Court of Common Pleas. However, this does not necessarily mean it was a faulty line of defense. In fact, the relatively high percentage of defendants employing this defense consistently across the fifteenth century suggests that perhaps it was acceptable as a way of legitimizing violence. 141 defendants out of 1600 total (592 defendants in just assault cases) used this throughout the fifteenth century before the Court of Common Pleas. That so many continued to justify their actions in this way

\footnotetext{
${ }^{76}$ In terms of undermining the legal statutes in place, see the discussion found in chapter one of Barbara Hanawalt, 'Of Good and Ill Repute': Gender and Social Control in Medieval England (Oxford: Oxford University Press, 1998).

${ }^{77}$ I discuss these ten cases in more detail in chapter four.

78 The full defense in Latin was "Dicit quod idem Thomas die et anno supradictis in parochia et warda praedictis in ipsum Willelmus insultum fecit et ipsum verberasse et vulnerasse voluit per quod idem Willelmus adtunc se defendebat prout ei bene licuit." TNA, CP 40/604, rot. 111d.
} 
strongly suggests that this was an acceptable use of violence by societal standards.

The continual use of this defense to argue that certain violent actions by private individuals were licit demonstrates that certain people were loath to let go of particular ideas about personal rights to violence. These ideas were firmly rooted in centuries prior and continue to be debated even in the modern day. When examining instances of homicide, a self-defense plea established that when one's life was on the line, that one could defend oneself and reasonably expect a pardon for the killing afterwards. As Thomas Green explains, "Pardons for self-defence, accident and insanity were, by the late thirteenth century, pardons of course; all who deserved them according to the rules of the law were to receive them." ${ }^{79}$ However, this applied to felonies for which the penalty was death, not to trespasses. The majority of the pleadings by defendants claiming self-defense in trespass vi et armis across the fifteenth century claimed the plaintiff initiated the violence so that they (the defendant) were forced to defend themselves. The simplicity of this defense suggests that it was a commonly held belief that one had the right to defend oneself from attack. Some defendants elaborated by explicitly saying it was within their rights to do so, but most did not. William Ussher, as discussed above, explicitly cited that it was his right (bene licuit), whereas John Braynok, for example, claimed self-defense in his pleading, but did not add the phrase bene licuit. ${ }^{80}$ The longevity of this defense indicates it was a firmly entrenched social norm that violence in self-defense was licit, even if the law might disagree.

However, one argument over whether a violent act was licit or illicit seems to have been settled during the fifteenth century: self-help violence or using violence to assert a right rather

\footnotetext{
${ }^{79}$ Thomas A. Green, "Societal Concepts of Criminal Liability for Homicide in Mediaeval England," Speculum 47, no. 4 (1972), 670.

${ }^{80}$ TNA, CP 40/612, rot. 128; TNA, CP 40/871, rot. 123.
} 
than using the courts. When examining the larger dataset, only forty-seven defendants, out of 1600, argued that their violence was licit because of prior actions by the plaintiff; none did so after 1450. To be clear, the self-help violence described in the records of the Court of Common Pleas does not match that which Warren Brown calls violent vengeance, although they seem related in ideology. Brown discusses violent vengeance as righting a wrong; either someone attacked you, stole from you, or even just humiliated you, so you retaliated with violence. ${ }^{81}$ Violent vengeance, like self-help violence, meant taking the law into one's own hands. Vengeance suggests rectifying wrongs, real or perceived, done to either oneself or one's kin; it denotes a certain comeuppance factor. Self-help violence, according to the pleas of defendants was more in line with recovering debts, or items loaned, through the use of violence. For instance, when John Michell, mercer and citizen of London, pleaded a special issue in his defense, he specifically claimed that John Ros (the plaintiff in the case) owed him twelve pounds and he had gone to see Ros to collect that debt. ${ }^{82}$

Even though defendants used this in the first half of the fifteenth century, it does not mean juries were sympathetic. For example, in 1403, John Fishe accused John Hayne of assault and imprisonment, requesting forty pounds in damages. ${ }^{83}$ Hayne argued, in his defense, that he and Fishe had made a written agreement that Fishe would pay Hayne forty-four shillings and four pence by Christmas 1390. Hayne claimed that Fishe never paid the bond, so he had Fishe arrested for breach of contract, at which point Fishe might have incurred the alleged injury if he had resisted the arrest. In this instance, Hayne was not seeking violent vengeance, but employed violence in order to make Fishe pay the amount to which he had allegedly agreed. The jury and

\footnotetext{
${ }^{81}$ For more see Brown, Violence in Medieval Europe., especially pages 90, 109, 200-201, and 206.

82 TNA, CP 40/616, rot. 247.

83 TNA, CP 40/568, rot. 054.
} 
court acknowledged that Fishe had signed the bond and that Hayne had legally requested the arrest of Fishe. However, Hayne had not waited for the official order to do so, and therefore Hayne ended up having to pay Fishe forty shillings. ${ }^{84}$ Had Hayne waited for the legal documents, his use of violence would have been licit; that he undertook it on his own was what, according to the court, made it illicit.

Defense pleas of self-help violence were not necessarily accepted by either society or the courts, even in the first half of the century. Hayne's case in 1403 indicates that the court, and perhaps broader society, was already less accepting of people taking the law in their own hands and yet people continued to use this defense through 1450. As Mackman and Stevens's "Common Pleas" dataset only includes eleven years from the latter half of the fifteenth century, anything extrapolated from that can only be speculative. Nevertheless, it is highly suggestive that society after the Wars of the Roses (1455-1487) was less accepting of self-help violence than before, to the point that defendants seemed to have stopped using it at all. Whether this was caused by the military and political conflict at the national level or other societal shifts is impossible to tell from these records. It could be that after a long spate of violent upheaval, society had little patience for those who used violence in pursuit of debts or to claims goods as payment owed. It could also be that self-help violence was already on the way out of society's good graces before the wars ever occurred. In either case, it seems clear that by the sixteenth century, society preferred that people resort to the courts to recover monies rather than to personal use of violence.

\section{Conclusion}

\footnotetext{
${ }^{84}$ This was still only five percent of what Fishe had requested. Additionally, Fishe still had to answer Hayne in the Mayor's Court about the original bond.
} 
Trespass vi et armis cases make up between fourteen and fifteen percent of all the cases on plea rolls of the Court of Common Pleas. Jonathan Mackman and Matthew Frank Stevens's project on the Court of Common Pleas, which only covers thirty-seven years but spans the fifteenth century, lists over 6,300 pleaded cases and only 921 concerned violent torts (or fifteen percent of the total cases). ${ }^{85}$ These numbers illustrate two things: first, that this was a busy court. Second, although these were civil proceedings, litigants used the Court of Common Pleas to bring actions concerning violence and violent acts. Both of these factors indicate that this court can contribute to our understanding of how medieval Londoners conceptualized licit and illicit violence, which was usually based predominantly on felonies or misdemeanors. When examined in detail, the cases show more distinctly the nuance in the negotiations taking place among society's members over issues of violence, as demonstrated throughout the previous chapters. When one pulls away from the minutiae and individual details of the cases to statistically examine a larger dataset, one gets a better comprehension of the variances in damages requested in relation to gender, occupation, and status. Using a larger dataset to complement my work not only reinforces the differences in damages requested but also better demonstrates the variances between torts. Mackman and Stevens's "Common Pleas" dataset also enables me to analyze how litigant strategies changed over time; the data suggests that at least one type of violent act allowed to be used by individuals at the beginning of the century was forbidden by the end of it.

The data from both datasets indicates that women's violence, done to them and by them, was perhaps valued less than that carried out by men against men. Combining the Mackman and Stevens's "Common Pleas" and dissertation datasets shows that the average amount of damages

\footnotetext{
${ }^{85}$ That is only 14.6 percent. Jonathan Mackman, and Matthew Frank Stevens, "Introduction to the Edition." Court of Common Pleas: The National Archives, CP40: 1399-1500 British History Online (2010): http://www.britishhistory.ac.uk/report.aspx?compid=119286. 6,321 according to Stevens, “London's Married Women,” 122.
} 
requested in cases involving women was twenty-five percent less than the average amount of damages requested in cases involving only men. The lower amount, on average, of damages requested supports the idea that women were considered secondary to men: a societal norm perpetuated by proscriptive literature. That the average amount of damages requested was less when women were involved might also suggest the economic positions of women in this society. Because women, by their legal status imposed by common law were 'covered' by their husbands, they often had less control of their finances. In other words, the Court of Common Pleas records for trespass vi et armis cases for this time period seems to support that women's economic status was lower than men's economic status. This data also shows that women not only were victims of violent acts, but perpetrated them as well, like the case involving Eleanor Phillip mentioned at the start of this chapter. Overall, women appeared as litigants in over twenty percent of the trespass vi et armis actions. In many of these cases, they appeared as litigants alongside their husbands, but they also pursued and defended cases on their own. Their presence defies societal norms of the fifteenth century that women should be non-violent, while supporting societal norms that women should have less control of financial assets and perhaps be less threatening.

Examining damage requests in relation to status and occupation also yielded mixed results. Plaintiffs in cases with a status or occupation listed for either of the litigants requested damages that were, across both datasets, on average, twenty percent higher than cases with neither status nor occupation listed. This suggests a strong correlation between how plaintiffs decided on damages and whether they or the defendant had a source of income. Plaintiffs considered whether their economic fortunes had been impacted by the alleged violence, and if the defendants had a job to finance the requested damages. Therefore, assessing a legal opponent's value or financial worth was a critical part of litigating violence. What may seem 
strange considering the socio-economic hierarchy in place during the fifteenth century is that plaintiffs requested more in damages, on average, when there was an occupation than when there was a person of a particular status involved in the case. Perhaps this is a by-product of examining cases with Londoners; as an urban area and the largest city in England, economic status may have been more important than the status systems in place at the time. If one examined cases enrolled in a more rural county, other results might emerge.

Savvy litigants continued to use the court to negotiate over licit and illicit violence throughout the fifteenth century. Defendants consistently claimed that violence was either licit, as in the case of self-defense or self-help, or that it had been privately regulated through prior arbitration. In the cases of self-defense and prior arbitration, these defenses were used throughout the entirety of the fifteenth century, indicating that there was some violence that private individuals refused to relegate to control by the crown or courts. However, self-help violence, while never an overly abundant defense, declined in use over the century. No defendants claimed self-help after 1450, which suggests that the Court of Common Pleas, and perhaps other individuals, had stopped believing that this was an acceptable use of violence. While it is unclear why this occurred, it could be the culmination of a decades-long shift away from self-help as an explanation, which was a trend that began even before the fifteenth century; or it could be a result of a saturation of violence during the mid-century civil wars.

This chapter represents the first foray into examining how views of violence, licit or illicit, changed over time by using cases of trespass vi et armis from the Court of Common Pleas. The statistical data when examining gender, occupation, and status, clearly shows the influence of societal norms as individuals accessed this court to pursue their interests and aims. Yet, the formulaic records of the court do not allow the researcher to ascertain whether these were 
conscious decisions or a result of unconscious biases. Answers to whether litigants purposefully valued violence against women or that committed by women as less than that committed by and against men are information we may never obtain, but these cases are suggestive. Perhaps more knowable was why occupation outstripped status by eleven percent when examining damage requests, but this would require more than just the records of the Court of Common Pleas to uncover. It does indicate that for Londoners before the Court of Common Pleas at least, economic status was more important than a title was, and that economic status intersected with gender. Furthermore, more work in the Court of Common Pleas is needed to fully assess when changes to societal views on self-help began to shift away from its acceptance as licit violence and towards the view that it was illicit. 


\section{Epilogue - A Case for the Court of Common Pleas}

In what is perhaps the fourth most memorable scene in Quentin Tarantino's cult classic, Pulp Fiction, a recently assaulted Marsellus Wallace (played by Ving Rhames) begins to beat one of his attackers. After using a shot gun to emasculate Zed, the only one of three rapists left alive, Wallace proceeds to describe the treatment in store for him, ending with the now iconic line, "Imma get medieval on your ass." ${ }^{1}$ While variations of this phrase appeared before the 1994 movie, its usage by Rhames's character in this scene perfectly encapsulates modern connotations of what it means to "get medieval." As Kory Stamper points out in her examination of its origins, this phrase is now firmly rooted in modern lexicon as meaning "to violently hurt" or "brutally beat" someone; it can also mean to be violent towards an object. ${ }^{2}$ Part of the blame for this link between brutality, violence, and the Middle Ages can be laid squarely at the doorstep of prominent Renaissance humanists who claimed that they were preceded by a dark period in Europe history, a more violent and chaotic period than what came after. Yet part of the blame also rests on modern popular depictions, which seem to focus on the worst parts of medieval society. In the short video by Stamper, she shows a number of popular television shows and movies where the phrase "getting medieval" is employed, whether about something, or someone. However, part of the blame, further still, belongs to the men and women of the Middle Ages, who could, indeed, be violent.

\footnotetext{
${ }^{1}$ Quentin Tarantino, and Roger Avary, Pulp Fiction, Directed by Quentin Tarantino, (Los Angeles: Miramax, 1994) DVD.

${ }^{2}$ Kory Stamper, "Where Did the Phrase "get medieval on your ass" Come From?" A.V. Club's Pop Lexicon (2018): accessed 3/14/2019, https://www.avclub.com/where-did-the-phrase-get-medieval-on-your-ass-come-fr-1823196177. Stamper works as a lexicographer and editor for Merriam-Webster. Carolyn Dinshaw also addresses this scene and the use of "get medieval" in her book, Getting Medieval: Sexualities and Communities, Pre- and Postmodern (Durham, NC: Duke University Press, 1999), 204-11. While Dinshaw does address some of ideas of violence in the scene and the line, she focuses more on what it says about homosocial and homoerotic relationships as presented in Pulp Fiction.
} 
While Wallace operated outside of the law on a regular basis, his actions against his rapists might be construed by many as a licit use of violence; in the early Middle Ages this would have been considered violent vengeance. ${ }^{3}$ However, by the fifteenth century this style of "getting medieval" was not as accepted as it had been earlier in the Middle Ages. Negotiations between private individuals, and between individuals and the courts, over what counted as licit and illicit violence restricted the use of violent vengeance. This does not mean that a person was never permitted to use violence; but, as people increasingly turned to the courts, as reflected by the increase in suits, the instances in which violence by a private individual was acceptable decreased.

Violence itself did not stop. Knowledgeable plaintiffs in the fifteenth century brought actions to court using trespass vi et armis concerning incidents that might have, a century earlier, been handled as a private matter; they did this knowing that resorting to violence themselves could land them in court. In addition, the motives behind why a plaintiff went to court might have included so much more than just vengeance. Forcing a defendant to deal with the hassle of a court case might be vengeance enough. The plaintiff may have wanted to push a defendant into arbitration so that the status quo could be restored. While defendants continued to use defenses such as self-defense throughout the fifteenth century, according to an analysis of a selection of $v i$ et armis cases before the Court of Common Pleas, they stopped using violent vengeance and self-help violence as justifications for violent acts somewhere around the middle of the century.

Socialization through family and kin helped people understand which acts of violence

\footnotetext{
${ }^{3}$ Emasculation was also the prescribed punishment for medieval rapists, if convicted. Kristi Gourlay, "Roses and Thorns: The Prosecution of Rape in the Middle Ages," Medieval Life 5 (1996), 31; Ruth Kittel, "Rape in ThirteenthCentury England: A Study of the Common-Law Courts," In Women and the Law: The Social Historical Perspective, edited by D. Kelly Weisberg, (Cambridge, MA: Schenkman, 1982), 110; Patricia Orr, "Men's Theory and Women's Reality: Rape Prosecutions in the English Royal Courts of Justice, 1194-1222," In The Rusted Hauberk: Feudal Ideals of Order and Their Decline, edited by Liam O. Purdon, and Cindy L. Vitto, (Gainseville, FL: University Press of Florida, 1994), 125.
} 
were acceptable and which were not, and these cases suggest that socialization was a process and that notions of licit violence were in flux and changed over time. The performative nature of the legal system also helped with this socialization. Defendants knew what types of defenses their neighbors and fellow Englishmen would accept. The Court of Common Pleas continued to be a busy court throughout the fifteenth century, with almost fifteen percent of its caseload concerning violence.

As a busy court, it is not surprising that researchers might shy away from it. Between 1405 and 1415 there were roughly 12,000 individual rolls to examine. ${ }^{4}$ My task was made easier by focusing on cases enrolled in London and looking specifically for trespass vi et armis, but the hours spent doing that were substantial. That research yielded eighty-two cases, and some might not see how the ends justify the means. However, the richness of these sources means that any number of hours needed to extract the information is time well spent. It is difficult to conceive of how much information could be gathered about any number of topics if one is just willing to wade through this vast pool of sources. Even within these trespass vi et armis actions, one can discover more than just acts of violence; so, too, could one find instances of violence in cases about economic disputes. Examining civil suits can help break down artificial barriers that historians employ like debt and homicide which can prevent a fuller understanding of what was really unfolding on the ground.

A limited, albeit useful, finding aid for this court is in the data that Jonathan Mackman and Matthew Frank Stevens have made available, covering thirty-eight years (forty percent of the fifteenth century); this can help serve historians as a resource who wish to sample cases from the Court of Common Pleas in their studies. With over 6,000 entries ranging from land disputes to

\footnotetext{
${ }^{4}$ This estimate was made using an average of 300 rolls per law term, with four law terms in a year.
} 
breaches of contract to violence in the Court of Common Pleas records, social, economic, and political historians would find these legal cases useful. I think historical research across a variety of fields would benefit if this database was expanded to encompass all the pleaded records for the century, from all English counties.

Even in cases ostensibly about violent acts, information about other aspects of economic and social life abound. Included in the defense pleadings I examined were hints at how people took out loans, what they used as collateral for those loans, and in some instances, how those loans were called in to be repaid. These cases showed how certain items were valued. This can help someone uncover relative wealth or social standings for the people involved. The collateral goods could also provide more information about cultural capital. Additionally, in plaintiff counts, in cases dealing with theft, were lists of the goods allegedly stolen. In many instances these goods were lumped together in cost rather than enumerated individually, but the wealth of information about material goods present in these cases was astounding. Furthermore, the decision to use the Court of Common Pleas for cases of theft is an interesting one considering the plaintiffs would not get their goods returned to them, based on the rules and procedure of the court.

Given the low conclusion rates for cases in the Court of Common Pleas, roughly nine percent for the cases considered in this dissertation, one questions why litigants chose this court. In those cases that did conclude in favor of the plaintiff, they usually received, on average, ten percent of what they requested in damages. For many, it cost more to bring the suit to court than they received in compensation. More often than not, though, plaintiffs failed to follow through with their suits. This might be explained through the continued popularity of settling disputes through arbitration. As historians have shown, savvy litigants often used the courts in concert 
with arbitration, bringing reluctant parties to the bargaining table through threats of lawsuits. ${ }^{5}$ Perhaps plaintiffs chose the Court of Common Pleas for this to lend more weight to the threat, as outside of London this was the only court in which a defendant could be detained in advance of their appearance, thus forcing that appearance in the court. A plaintiff who had tried to use a trespass action in a local court to force arbitration to no avail might have escalated the trespass action to the Court of Common Pleas to illustrate their resolve in obtaining satisfaction for the wrong done to them.

The cases I examined in this dissertation suggest that concern for reputation played a part as well as other motivations. Reputation, personal or business, was an important feature in medieval life. Once lost, it was difficult, if not impossible, to regain. Additionally, men and women worried about different aspects of reputation; women had to be more concerned with their sexual reputation than men did. ${ }^{6}$ Litigants, both plaintiffs and defendants, showed in their cases that their reputation in the wider community was an important factor. Plaintiffs demonstrated this by bringing the case before the court, for example. In addition, their narratives of the events highlighted points they felt would be in their favor if it went to a jury. Defendants employed the same strategy. In their pleadings, defendants used social mores that made their actions, and hence themselves, look more favorable. Further examination of a larger sample of cases might help to shed greater light on these issues of reputation.

With a close examination of eighty-two cases spanning a ten-year period of time, I

\footnotetext{
${ }^{5}$ For an overview of arbitration and the courts, see Edward Powell, "Arbitration and the Law in England in the Late Middle Ages (The Alexander Prize Essay)," Transactions of the Royal Historical Society 33 (1983); Edward Powell, "Settlement of Disputes by Arbitration in Fifteenth-Century England," Law and History Review 2, no. 1 (1984); Matthew Frank Stevens, "Failed Arbitrations before the Court of Common Pleas: Cases Relating to London and Londoners, 1400-1468," Journal of Legal History 31, no. 1 (2010).

${ }^{6}$ For more about reputation, sexual or otherwise, see Caroline Dunn, Stolen Women in Medieval England: Rape, Abduction, and Adultery, 1100-1500 (Cambridge: Cambridge University Press, 2012); Barbara Hanawalt, 'Of Good and Ill Repute': Gender and Social Control in Medieval England (Oxford: Oxford University Press, 1998); Jennine Hurl-Eamon, Gender and Petty Violence in London, 1680-1720 (Columbus: Ohio State University Press, 2005).
} 
demonstrate that litigants were knowledgeable of the courts available to them and that they used the procedures of the courts to their advantage. In addition, I show how litigants in cases of trespass vi et armis crafted narratives highlighting not only believable instances of violence for the court and for juries, but also reasonable defenses. While these plaintiffs and defendants may not have been telling the truth, something we will never know, their stories needed to be within the realm of possibility in order to be heard by the courts and move from the pleading to the trial stage. In cases where defendants pleaded a special issue, I was able to glean even more information about how litigants debated the classification of certain acts of violence, which may reflect broader understandings of violence. Part of this classification is evident in the different procedural guidelines between self-defense pleadings in criminal and civil procedures. The eighty-two cases in the dataset analyzed in this dissertation suggest that the special pleadings of self-help and self-defense were considered licit, at least enough for defendants to use them in them in their pleas. Furthermore, these cases hint at how gender and occupation influenced concepts of value, as seen through an analysis of damage requests.

Expanding the dataset to include cases from Mackman and Stevens's "Common Pleas" data suggests strongly that concepts of violence were not static. While pleadings of self-defense and prior arbitration seemed to remain steady through the fifteenth century, claims of self-help violence seem to have tapered off, or at the least declined, by $1450 .{ }^{7}$ This conclusion is in line with scholars who study concepts of violent vengeance as well as self-help violence. Over the course of the Middle Ages, rulers increasingly regulated what types of violence their subjects could use and the circumstances of that violence. ${ }^{8}$

\footnotetext{
${ }^{7}$ Mackman and Stevens's "Common Pleas" data, though only includes two years from the tail end of the fifteenth century.

${ }^{8}$ See, especially, Warren C Brown, Violence in Medieval Europe (Harlow, UK: Pearson Education Limited, 2011); Philippa C. Maddern, Violence and Social Order: East Anglia 1422-1442 (Oxford: Oxford University Press, 1992);
} 
The larger dataset that I analyzed in chapter five also illustrates some exciting new findings for studying violence in trespass vi et armis cases. A statistical analysis of 974 cases spanning forty-one years dispersed throughout the fifteenth century from the Court of Common Pleas clearly showed that the gender of people involved in the case influenced how much a plaintiff requested in damages. When women were involved, plaintiffs requested, on average, twenty-five percent less money in damages than when only men were involved. In addition, when taking into account occupation and status, plaintiffs requested, on average, twenty-two percent less in monetary compensation when neither the occupation nor status of the litigants was included in the plea rolls. Since the cases I examine in this dissertation only relate to Londoners, there is great room for expansion into questions about the way in which litigants used the action of trespass vi et armis in the Court of Common Pleas to further their goals and the ways in which they (both the litigants and the goals) were influenced by gender and status, as well as geography and location.

The expansion of this study could encompass a variety of projects. Of particular interest would be a close examination of 1480 to 1490 in order to see how the influence of gender and occupation might have changed, but also to see what changes are visible in the motivations of the litigants, as well as what changes were wrought in the negotiations over licit and illicit violence. Did self-help stop being used by defendants? Was self-defense still as common a defense as it was between 1405 and 1415? Did the circumstances surrounding violence, according the plaintiff allegations, change? Was arbitration still a common way for private individuals to repair the damage done by violence? An expansion geographically, as opposed to time, would yield an exciting examination into how litigants from rural settings might have different motives or

Hannah Skoda, Medieval Violence: Physical Brutality in Northern France, 1270-1330 (Oxford: Oxford University Press, 2013) for studies that have contributed to this scholarship 
knowledge of the courts than litigants from urban settings. Both types of expansions would add to our knowledge of gender, status, and occupation and how these might have influenced concepts of value, but also what role they might have played in negotiations over violence. Even larger than a comparison of two decades at opposite ends of the century or expanding to all of England across the same time period, would be to study the entire century of data.

This would be a massive undertaking, but the value added to the current scholarship on violence, gender, and the law would be extensive. In this dissertation, I have already contributed to this conversation in a small way by showing that while the crown may have wanted to have greater control over violence (possibly leaning towards a monopoly) as indicated by the creation of trespass vi et armis as an action as well as new statutes against violence in the century before, society was not willing to abandon all rights to private violence. Men and women were violent, but more important than their use of violence, for vengeance or otherwise, was that they also used the courts to achieve justice (whatever that might entail for them) and to explain and justify the violence. While women remained a small subset of those individuals before the court, that they were sued for violent acts and litigated in their own right for violence done to them adds to our knowledge of women's activity in the fifteenth century as well as to understandings of women's behavior. Additionally, through the court records, one can see how violence might have occurred: running one's business, moving through the streets of a city, running errands for an employer, or collecting a debt. As map two indicates, this violence could happen anywhere in London; there were no discernable trends as to where or when the violence might occur. ${ }^{9}$ Violence could catch someone unaware, altering the course of their life, forcing them to confront a concept that they may not have consciously thought about before: was this violence that they

\footnotetext{
${ }^{9}$ See Map 2 on page 135.
} 
should ignore, that warranted arbitration, that was bad enough for them to go to court, or perhaps that they should handle themselves? For some people of the early fifteenth century, "getting medieval" may have indeed looked like Wallace's version of violent vengeance, but for many medieval Londoners it entailed the not unsubstantial mountain of paperwork and fees necessary to take someone to court. 


\section{Appendices}

Appendix A: Litigants in Trespass vi et armis Cases Between 1405 and 1415 (Broken Down By Occupation or Status)

Table 7 - Litigants in Trespass vi et armis Cases Between 1405 and 1415 (Broken Down By Occupation or Status), Appendix A

\begin{tabular}{|c|c|c|c|c|}
\hline Occupation & Plaintiffs & Percentage & Defendants & Percentage \\
\hline No Occupation or Status & 53 & $57 \%$ & 63 & $44 \%$ \\
\hline Armorer & 2 & $2 \%$ & & \\
\hline Attorney & 1 & $1 \%$ & 2 & $1 \%$ \\
\hline Barber & 1 & $1 \%$ & 2 & $1 \%$ \\
\hline Brazier & & & 2 & $1 \%$ \\
\hline Brewer & & & 4 & $3 \%$ \\
\hline Butcher & 1 & $1 \%$ & 3 & $2 \%$ \\
\hline Carpenter & & & 2 & $1 \%$ \\
\hline Chaplain & & & 4 & $3 \%$ \\
\hline Cleric & 2 & $2 \%$ & 6 & $4 \%$ \\
\hline Cook & & & 2 & $1 \%$ \\
\hline Cordwainer & 1 & $1 \%$ & & \\
\hline Cotiller & 1 & $1 \%$ & & \\
\hline Courser & & & 2 & $1 \%$ \\
\hline Dauber & & & 1 & $1 \%$ \\
\hline Dyer & & & 1 & $1 \%$ \\
\hline Fabricator & 1 & $1 \%$ & & \\
\hline Fishmonger & 1 & $1 \%$ & & \\
\hline Glasier & & & 6 & $4 \%$ \\
\hline Goldsmith & 2 & $2 \%$ & 1 & $1 \%$ \\
\hline Hosteler & & & 1 & $1 \%$ \\
\hline Ironmonger & 1 & $1 \%$ & & \\
\hline Laborer & & & 1 & $1 \%$ \\
\hline Leatherseller & 1 & $1 \%$ & & \\
\hline Limner & & & 1 & $1 \%$ \\
\hline Maltman & & & 1 & $1 \%$ \\
\hline Mercer & & & 2 & $1 \%$ \\
\hline Pewterer & & & 1 & $1 \%$ \\
\hline Pinner & & & 1 & $1 \%$ \\
\hline Priest & 1 & $1 \%$ & 1 & $1 \%$ \\
\hline Saltman & 1 & $1 \%$ & & \\
\hline Servant & 1 & $1 \%$ & 3 & $2 \%$ \\
\hline Shearman & 1 & $1 \%$ & & \\
\hline Skinner & & & 1 & $1 \%$ \\
\hline Souter & & & 1 & $1 \%$ \\
\hline
\end{tabular}




\begin{tabular}{|l|l|l|l|l}
\hline Stationer & & & 2 & $1 \%$ \\
\hline Steynour & & & 1 & $1 \%$ \\
\hline Tailor & & & 3 & $2 \%$ \\
\hline Tavener & & & 1 & $1 \%$ \\
\hline Textiler & 2 & $2 \%$ & & \\
\hline Wpholsterer & & & 1 & $1 \%$ \\
\hline Woaver & & & 1 & $1 \%$ \\
\hline Wright & 2 & $2 \%$ & & \\
\hline Esquire & & & 1 & $1 \%$ \\
\hline Gentleman & 3 & $3 \%$ & 2 & $1 \%$ \\
\hline Single (woman) & & & 2 & $1 \%$ \\
\hline Married (woman) & 5 & $5 \%$ & 6 & $5 \%$ \\
\hline Widow & 8 & $9 \%$ & 7 & $1 \%$ \\
\hline
\end{tabular}


Appendix B: Image of a Court of Common Plea roll (CP 40/572) from The National Archives, Kew, England

Image 1 - Court of Common Plea roll (CP40/572), Appendix B

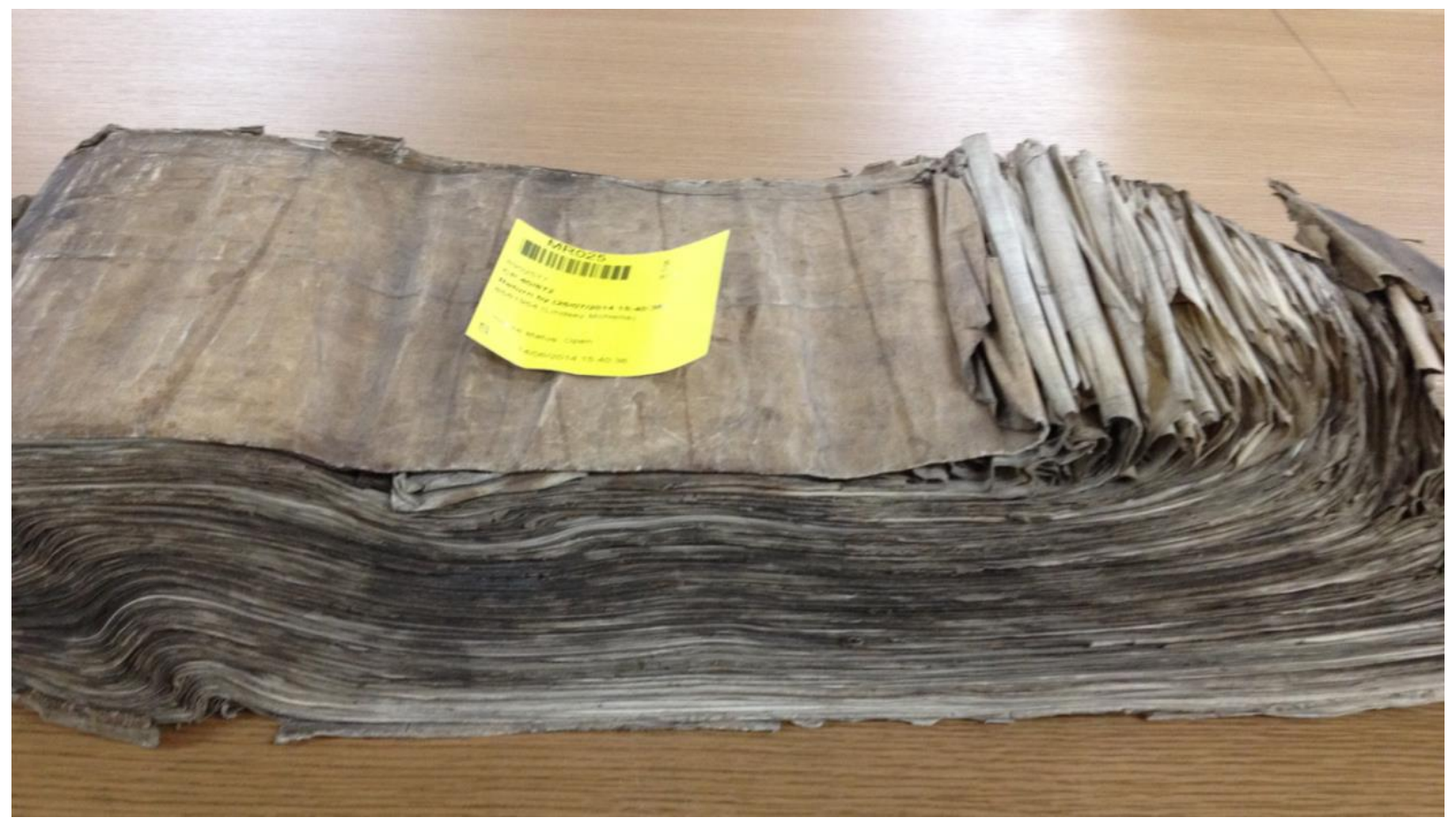




\section{Appendix C: Dates of Law Terms between 1405 and 1415, with corresponding Common Plea headings}

\author{
CP40/576 - Hilary, 1405 - 1/23-2/12 \\ CP40/577 - Easter, 1405 - 5/6-6/1 \\ CP40/578 - Trinity, 1405 - 6/24-7/15 \\ CP40/579 - Michaelmas, 1405 - 10/9-11/28 \\ CP40/580 - Hilary, 1406 - 1/23-2/12 \\ CP40/581 - Easter, 1406 - 4/28-5/24 \\ CP40/582 - Trinity, 1406 - 6/16-7/7 \\ CP40/583 - Michaelmas, 1406 - 10/9-11/29 \\ CP40/584 - Hilary, 1407 - 1/24-2/12 \\ CP40/585 - Easter, 1407 - 4/13 - 5/9 \\ CP40/586 - Trinity, 1407 - 6/1-6/22 \\ CP40/587 - Michaelmas, 1407 - 10/10-11/28 \\ CP40/588 - Hilary, 1408 - 1/23-2/13 \\ CP40/589 - Easter, 1408 - 5/2-5/28 \\ CP40/590 - Trinity, 1408 - 6/20-7/11 \\ CP40/591 - Michaelmas, 1408 - 10/9-11/28 \\ CP40/592 - Hilary, 1409 - 1/23-2/12 \\ CP40/593 - Easter, 1409 - 4/24-5/20 \\ CP40/594 - Trinity, 1409 - 6/12-7/3 \\ CP40/595 - Michaelmas, 1409 - 10/9-11/28 \\ CP40/596 - Hilary, 1410 - 1/23-2/12 \\ CP40/597 - Easter, 1410 - 4/9-5/5
}

\author{
CP40/598 - Trinity, 1410 - 5/28-6/18 \\ CP40/599 - Michaelmas, 1410 - 10/9-11/28 \\ CP40/600 - Hilary, 1411 - 1/23-2/12 \\ CP40/601 - Easter, 1411 - 4/29-5/25 \\ CP40/602 - Trinity, 1411 - 6/17-7/8 \\ CP40/603 - Michaelmas, 1411 - 10/9-11/28 \\ CP40/604 - Hilary, 1412 - 1/23-2/12 \\ CP40/605 - Easter, 1412 - 4/20-5/16 \\ CP40/606 - Trinity, 1412 - 6/8-6/29 \\ CP40/607 - Michaelmas, 1412 - 10/10-11/28 \\ CP40/608 - Hilary, 1413 - 1/23-2/13 \\ CP40/609 - Easter, 1413 - 5/10-6/5 \\ CP40/610 - Trinity, 1413 - 6/28-7/19 \\ CP40/611 - Michaelmas, 1413 - 10/9-11/28 \\ CP40/612 - Hilary, 1414 - 1/23-2/12 \\ CP40/613 - Easter, 1414 - 4/25-5/21 \\ CP40/614 - Trinity, 1414 - 6/13-7/4 \\ CP40/615 - Michaelmas, 1414 - 10/9-11/28 \\ CP40/616 - Hilary, 1415 - 1/23-2/12 \\ CP40/617 - Easter, 1415 - 4/17-5/13 \\ CP40/618 - Trinity, 1415 - 6/5-6/26 \\ CP40/619 - Michaelmas, 1415 - 10/9-11/28
}




\section{Appendix D: Visual Representation of Court System in England, c. Fifteenth Century}

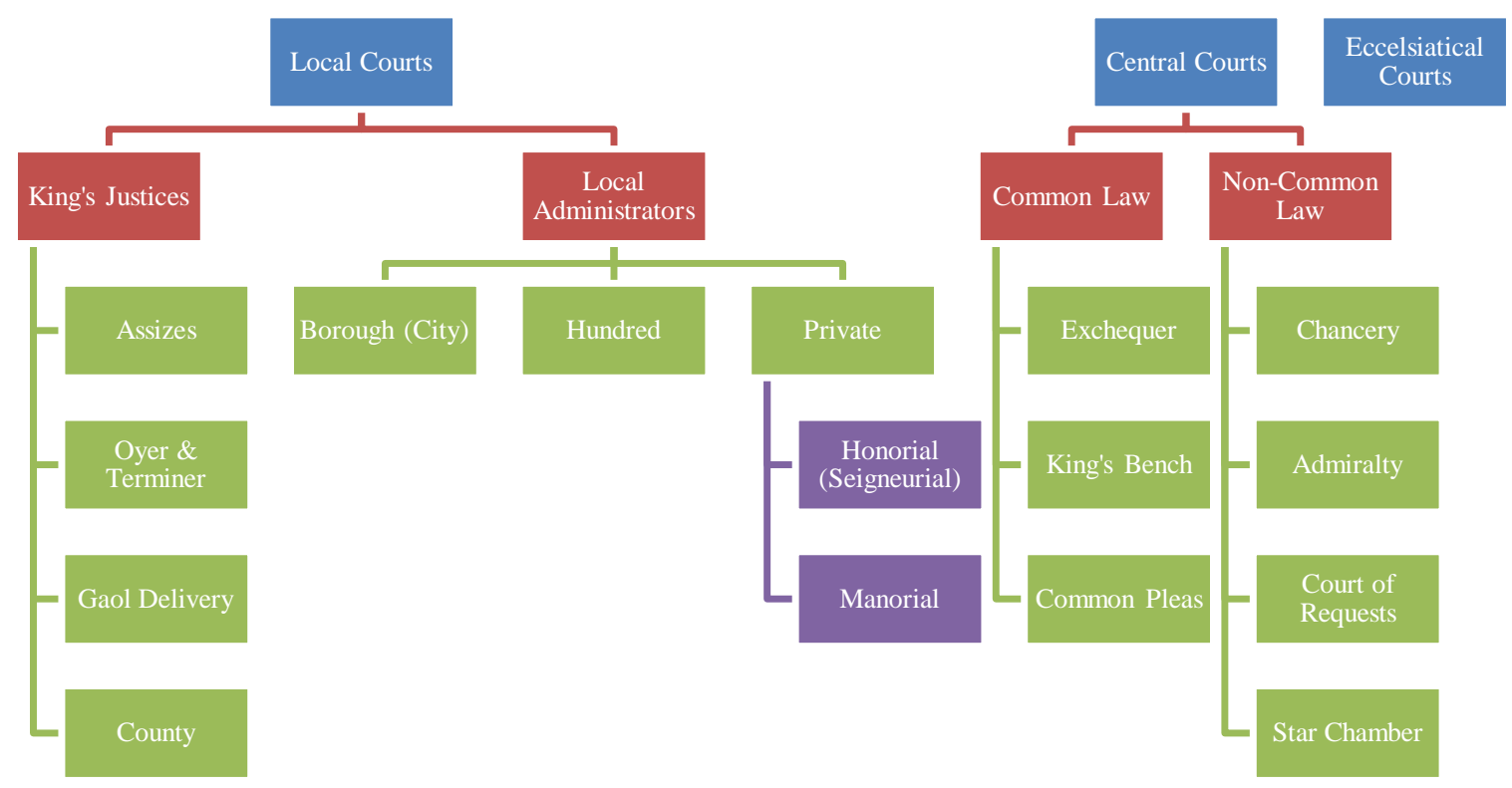

The Admiralty Court began hearing cases as early as 1357 but had limited jurisdiction. Chancery was hearing certain cases which had been removed from other courts from the mid thirteenth century but developed as a court of first resort by 1450. Star Chamber was officially created around 1487 and the Court of Requests developed in 1483. 


\section{Appendix E: Image of CP 40/576, rot. 250 from The National Archives, Kew, England}

Image 2 - Parts of a Case, Using CP40/572, rot. 250, Appendix E

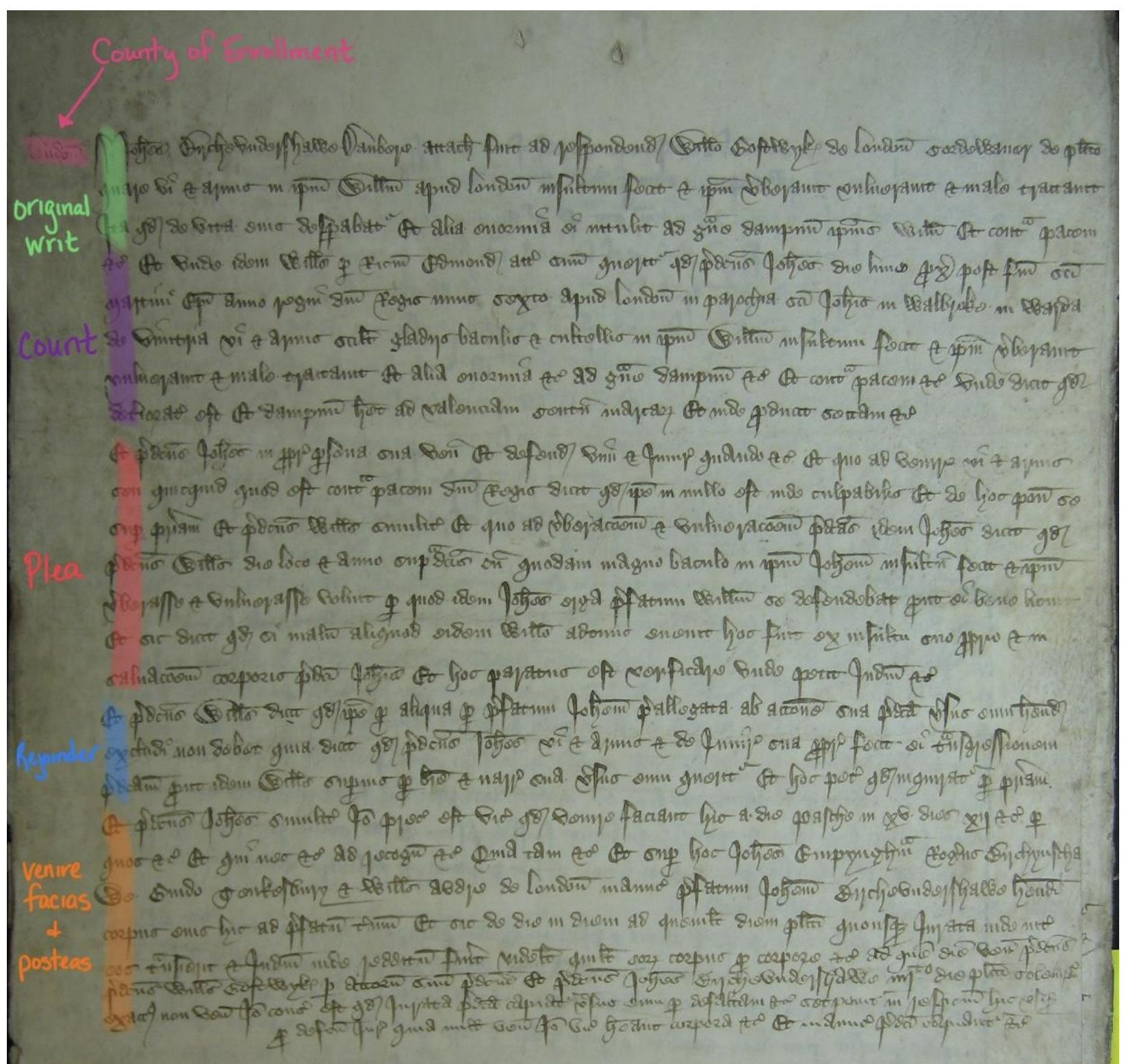




\section{Appendix F: Table of Cases by Torts}

Table 8 - Cases By Tort, Appendix F

\begin{tabular}{l|l}
\hline Torts by Case & $\begin{array}{l}\text { Number } \\
\text { of Cases }\end{array}$ \\
\hline Abduction & 12 \\
\hline $\begin{array}{l}\text { Abduction, } \\
\text { Housebreaking }\end{array}$ & 1 \\
\hline $\begin{array}{l}\text { Abduction, } \\
\text { Taking of } \\
\text { Goods }\end{array}$ & 8 \\
\hline $\begin{array}{l}\text { Abduction, } \\
\text { Taking of } \\
\text { Goods, } \\
\text { Housebreaking }\end{array}$ & 1 \\
\hline Assault & 19 \\
\hline $\begin{array}{l}\text { Assault, } \\
\text { Abduction, } \\
\text { Taking of } \\
\text { Goods }\end{array}$ & 1 \\
\hline $\begin{array}{l}\text { Assault, } \\
\text { Housebreaking, } \\
\text { Taking of } \\
\text { Goods }\end{array}$ & 3 \\
\hline $\begin{array}{l}\text { Assault, } \\
\text { Imprisonment }\end{array}$ & 5 \\
\hline $\begin{array}{l}\text { Assault, Taking } \\
\text { of Goods }\end{array}$ & 4 \\
\hline Housebreaking & 0 \\
\hline Imprisonment & 1 \\
\hline $\begin{array}{l}\text { Taking of } \\
\text { Goods }\end{array}$ & 18 \\
\hline $\begin{array}{l}\text { Taking of } \\
\text { Goods, } \\
\text { Disseisin }\end{array}$ & 1 \\
\hline $\begin{array}{l}\text { Taking of } \\
\text { Goods, } \\
\text { Housebreaking }\end{array}$ & 8 \\
\hline & \\
\hline
\end{tabular}




\section{Appendix G: Example of Information Contained in "Court of Common Pleas: The National Archives, CP40: 1399-1500" on British History Online}

\section{Court of Common Pleas, CP 40/872, rot. 442d}

Term: Easter 1480

County: London

Writ type: Trespass (force and arms)

Damages claimed: $£ 20$

Damages awarded: $33 s$ 4d

Costs: 60 s

Case type: Assault; Imprisonment

Pleading: Eleanor Phillip was arrested by her body to respond to 'John Breynton one of the clerks of John Broun prothonotary of this court of Common Pleas' touching upon the liberties and privileges of the same court of this kind of clerk and other ministers of the Common Pleas from time immemorial until this time and to this use etc. concerning a plea of trespass. In this plea, JB claims that on 29/04/1480 at London he was assaulted and imprisoned by EP with force and arms for the entirety of that same day, contrary to the law of the land. Damages are claimed at $£ 20$.

Pleading: EP defends and seeks licence to imparl as far as Trinity term 1480. Pledges are named for the defendant.

Postea text: postea 1 - to this day comes plaintiff JB, as well as defendant EP. And upon this EP says nothing to exclude the action of JB, and so JB seeks judgement; namely that EP be found guilty of the aforesaid trespass and that JB be awarded damages. Upon this the justices order the sheriff of London to make inquiry, by the oath of honest men, as to the damages sustained by JB, as much as a result of this trespass, as in costs surrounding this suit. This inquest is to report to this court in Michaelmas term 1480.

Postea text: postea 2 - the sheriff of London does not send the writ and so the case is forwarded as far as the quindene of Martinmas 1480 (late in Michaelmas term 1480).

Postea text: postea 3 - the sheriff of London returns that an inquest was held by the oath of twelve men in the guildhall of London on $23 / 11 / 1480$, which twelve men assessed the vale of JB's damages at $33 \mathrm{~s} 4 \mathrm{~d}$, and JB's costs surrounding this suit at $60 \mathrm{~s}$. Therefore, it is decided that $\mathrm{JB}$ is to recover this $93 \mathrm{~s} 4 \mathrm{~d}$ in costs and damages. EP is to be arrested.

\begin{tabular}{|l|l|l|}
\hline \multicolumn{1}{|c|}{ Type } & Place & Dats \\
\hline \hline \begin{tabular}{l|l|} 
Assault \\
Imprisonment
\end{tabular} & St Andrew Holborn < Farringdon Ward Without < London < England & (initial) 29/04/1480 \\
\hline
\end{tabular}

\begin{tabular}{|c|c|c|c|c|c|}
\hline \multicolumn{6}{|c|}{ Individuals } \\
\hline Individual & Status & Occupation & Institution & Place & Role \\
\hline Eleanor Phillip (f) & & & & & Defendant \\
\hline John Broun (m) & & Prothonotary & Common Pleas [court] & & Other \\
\hline Richard Lambe (m) & & Barber & & London < England & Surety for defendant \\
\hline Thomas Brigge $(\mathrm{m})$ & & Baker & & London < England & Surety for defendant \\
\hline William Brikhed (m) & Gentleman & & & London < England & Surety for defendant \\
\hline
\end{tabular}




\section{Appendix H: Images of FileMaker database created and used for this dissertation}

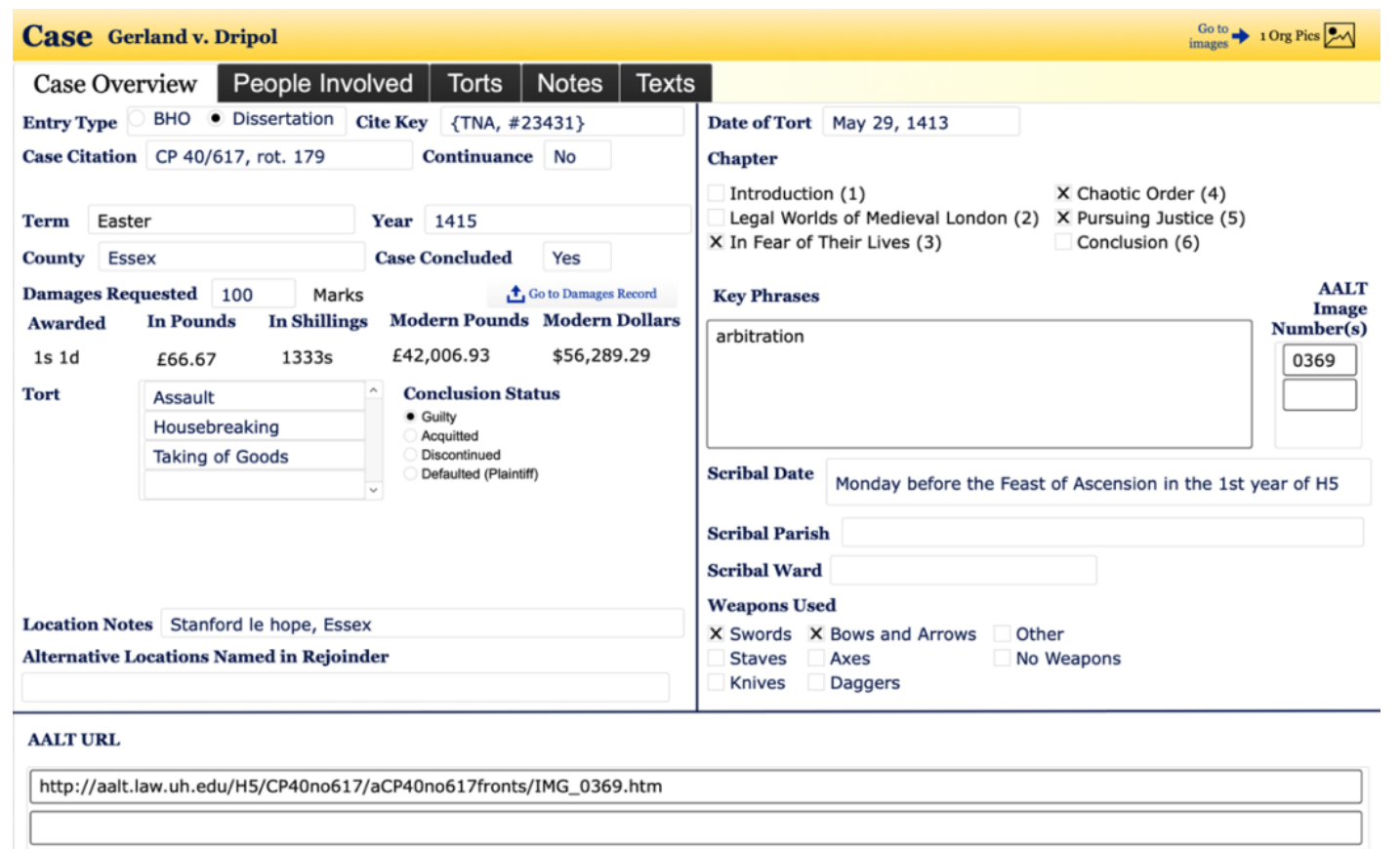

Case ID $\mathrm{CP} 190$

Image 3 - Example of Main Entry Information, FileMaker Screenshot, Appendix H

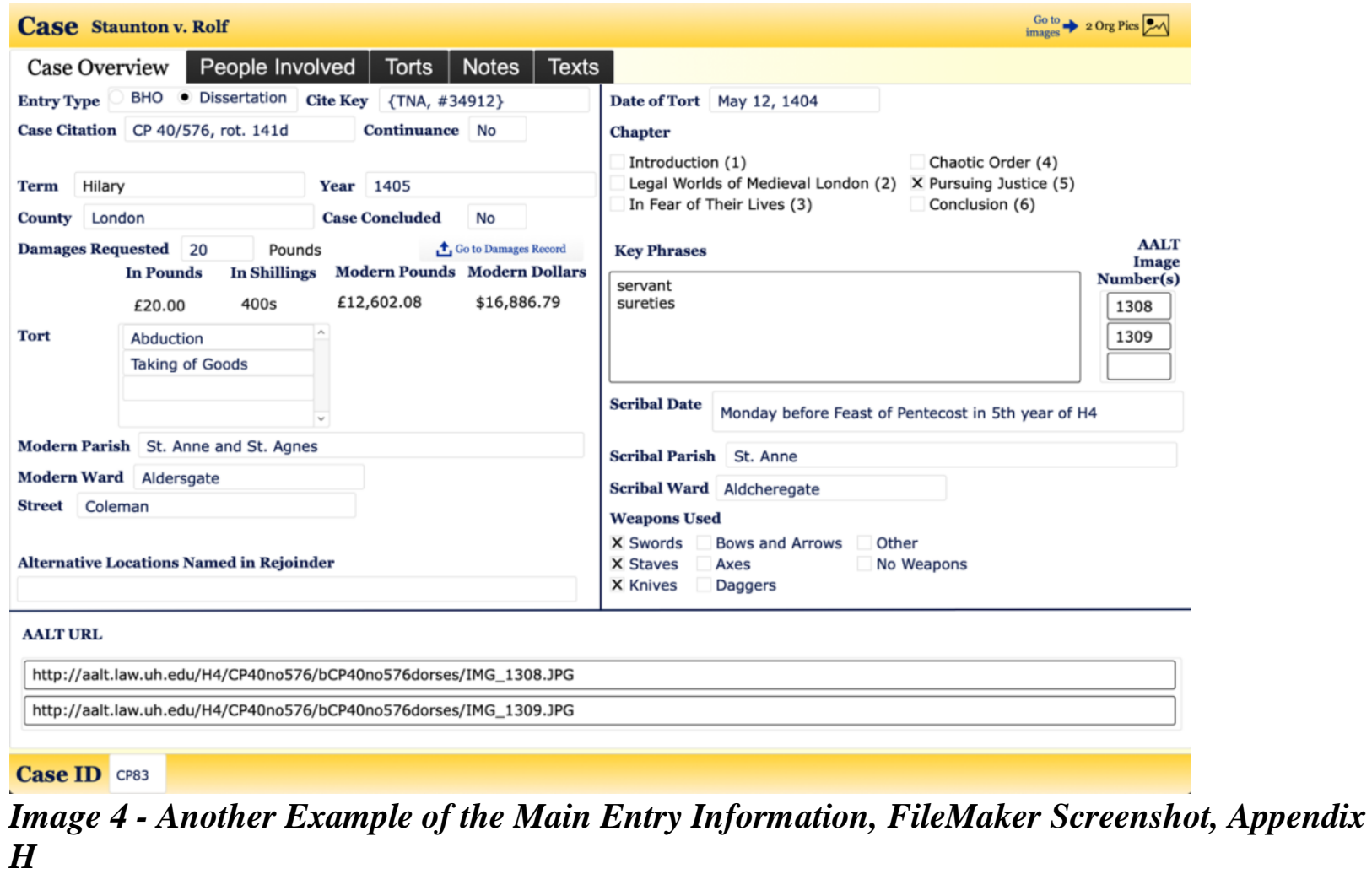


Case Gerland v. Dripol

\section{Case Overview}

People Involved

\begin{tabular}{l|l|l|} 
Torts & Notes & Texts
\end{tabular}

People in the Case

Name

Role in Case

2 John Dripol

2 John Gerland

2 William Kirkeby

2 John Blomster

2 John Dutton

2 John Cokayn

Defendant

Plaintiff

Attorney for Plaintiff

Arbitrator

Arbitrator

Judge

\begin{tabular}{ll} 
Gender & Occupation \\
\hline Male & Tailor \\
Male & \\
Male & Attorney \\
Male & \\
Male & \\
Male & Justice
\end{tabular}

Add New Person

Find Existing Person
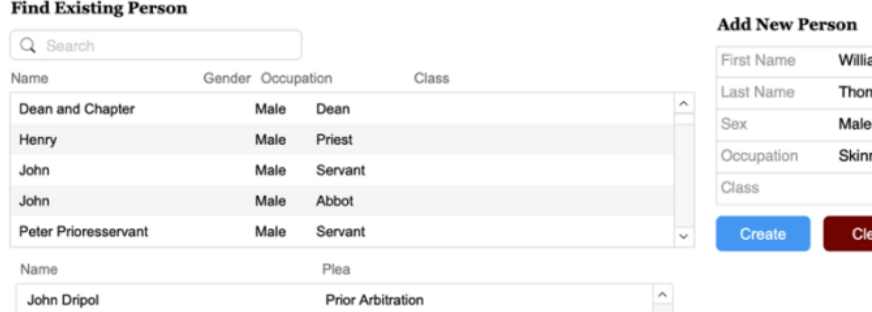

$\underset{\text { images }}{\text { Go to }} \rightarrow 1$ Org Pies

John Dipol

Prior Arbitration

Case ID $C P 190$

Image 5 - Example of Person Entry Information, FileMaker Screenshot, Appendix H

Case Staunton v. Rolf

\section{Case Overview}

People in the Case

\begin{tabular}{|c|c|c|c|c|}
\hline & Name & Role in Case & Gender & Occupation \\
\hline 2 & William Rolf & Defendant & Male & Hosteler \\
\hline 2 & Beatrice Tapster & Defendant & Female & \\
\hline 1 & John Staunton & Plaintiff & Male & Leatherseller \\
\hline 1 & William Weldon & Attorney for Plaintiff & Male & Attorney \\
\hline 1 & Robert Donmowe & Surety & Male & \\
\hline 2 & Henry Russell & Surety & Male & \\
\hline 1 & Robert Symney & Surety & Male & \\
\hline 1 & Richard Adryan & Surety & Male & \\
\hline 2 & Katherine Souper & Victim & Female & Servant \\
\hline
\end{tabular}

\section{Torts Notes Texts}

images $\rightarrow 2$ Org Pics

Find Existing Person

\begin{tabular}{|c|c|c|}
\hline \multicolumn{2}{|l|}{ Q Search } & \\
\hline Name & \multicolumn{2}{|c|}{ Gender Occupation } \\
\hline Dean and Chapter & Male & Dean \\
\hline Henry & Male & Priest \\
\hline John & Male & Servant \\
\hline John & Male & Abbot \\
\hline Peter Prioresservant & Male & Servant \\
\hline Name & & Plea \\
\hline William Rolf & & Not $G$ \\
\hline Beatrice Tapster & & Not Gui \\
\hline
\end{tabular}

Case ID ${ }^{C P} 83$

Image 6 - Another Example of Person Entry Information, FileMaker Screenshot, Appendix H 


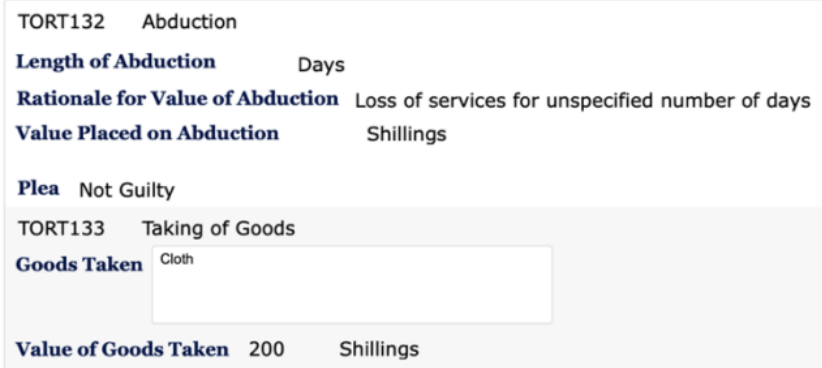

\section{Case ID ${ }^{C P 83}$}

\section{Image 7 - Example of Tort Entry Information, FileMaker Screenshot, Appendix H}

Case Staunton v. Rolf

\section{\begin{tabular}{l|l|l|l|l} 
Case Overview & People Involved & Torts Notes & Texts
\end{tabular}}

Notes

Pleading: John S. claims that William R., together with Beatrice T., used force and arms to seize and carry off his good at London to the value of $£ 10$, as well as seizing and abducting JS's servant Katherine $S$. so that she was out his service from the time of the trespass ( Monday next after the Pentecost 1404) as far as the time of the making of the writ (date of writ left blank). The goods taken were linen and woollen cloth. Damages are claimed at $£ 20$.

Pleading: WR says that he is innocent and puts himself upon the country, and JS puts himself likewise. Order to the sheriff etc. Pledges are named for the defendant.
Memo

Staunton v. Rolf, Hilary 1405

Memorandum

Citation: CP 40/576, rot. 141d

CiteKey: \{TNA, \#34912\}

Litigants: John Staunton v. William Rolf (Beatrice Tapster)

Tort(s): Theft, Kidnapping

Plea(s): Not guilty

Date: May 12, 1405, Monday before the feast of Pentecost in the 5th year of $\mathrm{H} 4$ Location: St. Anne, Aldersgate

Weapons: Swords, staves, and knives

Damages/Pounds/Modern \$: 20 pounds/400 shillings/Modern \$16,886.78

Key Phrases: servant, sureties

Contextual Summary: This case could be used in the Ad Dampnum chapter or in the statistics chapter. However, it is interesting for a couple of reasons. One, it is an example of an accessory not re-appearing in the case to plead. Two, it looks like the accessory and the abducted servant are from the same village

(Gildeford). And three, the scribe forgot to fill in the date of the original writ, so

I'm not sure how long Katherine Souper was gone for.

Case ID ${ }^{\mathrm{CP}} 83$

Image 8 - Example of Notes Entry, FileMaker Screenshot, Appendix H 
Case Staunton v. Rolf

\begin{tabular}{l|l|l|l|l} 
Case Overview & People Involved & Torts & Notes & Texts
\end{tabular}

Transcription

1.Will[elmu]s Rolf hostiler attach[iatus] fuit ad respondend[um] Joh[ann]i

Staunton de London letherseller de pl[ac]ito quare ip [s]e simul

2. Cum Beatrice Tapster de Gildeford vi et armis bona et catalla ip [s] ius Joh[an] is ad valentiam decem librar[um] apud

3. London inuent[a] cepit et asportanit et Kath [er] inam Souper de Gildeford s[er] vientem suam in $\mathrm{s}[\mathrm{er}] \mathrm{vias}$ suo ibi[dem] existentem

4. Cepit et abduxit $p[e r]$ quod idem Joh[ann]es $s[e r] v i e m$ servientis seu $p[r a e] d$

. Cepit et abduxit p[er] quod idem Joh [ann] es s[er vic

[icj.

5. Ei intulit ad g[ra] ve dampnu [m] ip [s] ius Joh [ann] is et cont[ra] pacem regis et

. Attorn [atum] suu[m] querit[ur] q[uo]d $p[r a e] d[i c]$ tus Will[elmu]s simul etc die lune $p[r o] x[$ imo] ante $f[$ estu] $m$ Pentecostes anno regni d omni]ni Regis 7. Nunc Quinto abud London in p ar jochia s[anc] ti Anne in Warda de

Aldcherhegate vi et armis sc

8 . Cultellis bona et catalla ip [s] ius Joh[ann] is videl[ice]t pannos lineos et laneos ad

9. Et asportanit et Kat [er] inam Souper de Gildeford $\mathbf{s}$ [er] vientem suam in s[er] vitis suo ib (idde] mexistentem cepit et abdux

10. $\mathbf{P}[\mathrm{er}]$ quod idem Joh [ann] es $\mathbf{s}[\mathrm{er}] \mathrm{viciu}[\mathrm{m}] \mathbf{s}[\mathrm{er}]$ vientis sue $\mathrm{p}[\mathrm{rae}] \mathbf{d}[\mathrm{ic}]$ te $\mathrm{p}[\mathrm{er}]$ magnu[m] tempus videl[ice] $t$ a $p$ [rae] dic] to die lune usq[ue] Diem impetraton

11. Br[ev] is scil[ice]t $\{$ large space\} amisit et alia enormia etc ad $g$ [ra]ve dampnu in] etc. et cont [ra]

12. Pacem etc. unde dic[it] q[uo]d detiorat[us] est et dampnu[m] h[ab]et ad valencia [m] viginti librar[um] et inde $p[r o] d u[c]$ t sectam etc

13. Et p[rae]d[ic]tus Will[elmu]s Rolf in p[ro]pria p[er] sona sua ven [it] et defend

14. $t$ [ra]nsgr[essione] p[rae]d [ic]tus in nullo est culpabilis et de hoc pon[it] se sup [er] $\mathbf{p}$ [at] riam et $\mathbf{p}[\mathrm{rae}] \mathbf{d}[\mathrm{ic}]$ tus Joh[ann] es similit[er] $\mathrm{i}[\mathrm{de}] \mathrm{o} \mathrm{prec[eptum]} \mathrm{vic}$

15. q[uod] venire fac[lat] hic a die pasche in xv dies xii p[er] quos etc et qui nec etc ad recogn [oscendum] etc. Quia tam etc.

16. et sup[er] hoc Rob[er]tus Donmowe Henr[icus] Russell Rob[er]tus Symney et Ric[ard]us Adryan de com[itate] Surr[ey] manuc[eperunt] p[rae]d [ic]t[u]m Will elm] us

17. Rolf $h$ [ab]endi corpus eius hic ad p[rae]fatum $t[e r] m i[n u m]$ et sic de die in diem ad queml[ibe]t diem pl[ac] iti quousq[ue] iur[ata] Inde int [er] eos 18. T[ra]nsierit et iud[icu]m inde redditum fu[er] it videl[ice]t quil[ibe]t eor[um] corpus $\mathrm{p}[\mathrm{ro}]$ corpore etc.

\section{Translation}

Willelmus Rolf hostiler attachiatus fuit ad respondendum Johanni Staunton de London letherseller de placito quare ipse simul cum Beatrice Tapster de Gildeford vi et armis bona et catalla ipsius Johanis ad valentiam decem librarum apud London inuenta cepit et asportanit et Katherinam Souper de Gildeford servientem suam in servias suo ibidem existentem cepit et abduxit per quod idem Johannes serviem servientis seu praedicte per magnum tempus amisit et alia enormia ei intulit ad grave dampnum ipsius Johannis et contra pacem regis et unde idem intulit ad grave dampnum ipsius Johannis et contra pacem regis et unde idem Willelmus simul etc die lune proximo ante festum Pentecostes anno regni domnini Regis nunc Quinto abud London in parochia sancti Anne in Warda de Aldcherhegate vi et armis scilicet gladiis baculis et cultellis bona et catalla ipsius Johannis videlicet pannos lineos et laneos ad valentiam etc. abud London inventa cepit et asportanit et Katerinam Souper de Gildeford servientem suam in servitis suo ibidem existentem cepit et abduxit per quod idem Johannes servicium servientis sue praedicte per magnum tempus videlicet a praedicto die lune usque Diem impetraton brevis scilicet $\{$ large space $\}$ amisit et alia enormia etc ad grave dampnum etc. et contra pacem etc. unde dicit quod detioratus est et dampnum habet ad valenciam viginti librarum et inde producit sectam etc

William Rolf, hosteler, was attached to answer John Staunton of London, eatherseller, in a plea why he, together with Beatrice Tapster of Gildeford, by force and arms took and carried away the goods and chattels of same John to the value of 10 pounds near London and took and abducted Katherine Souper of Gildeford, his servant, who served him in the same place, by the same John and was parted with the service of the aforementioned servant for a long time and other serious wrongs unto him, to the grave damage of that same John and against the peace of the king and for which the same John, through William Weldon, his attorney, complains that the aforementioned William together, etcetera, on the Monday before the feast of Pentecost in the fifth year of our lord King near London in the parish of St. Anne in the Ward of Aldersgate, by force and arms, namely with wooden swords and knives, took and carried away the goods and chattels of the same John, that is to say linen and woolen cloth to the value of, etcetera, near London and took and abducted Katherine Souper of Gildeford, his servant in service to him in the same place, by the same John and was parted with the service of the aforementioned servant for a long time, namely from the aforementioned day of Monday to the day of (the suit?) of the writ, namely ... and other wrongs etcetera, serious damage etcetera, and against the peace et cetera, and so he says that was wronged and has damage to the value of 20 pounds and brings this suit, etcetera

Case ID ${ }^{\mathrm{C} P} 8{ }^{3}$

\section{Image 9 - Example of Transcription and Translation Entry, FileMaker Screenshot, Appendix} $\boldsymbol{H}$

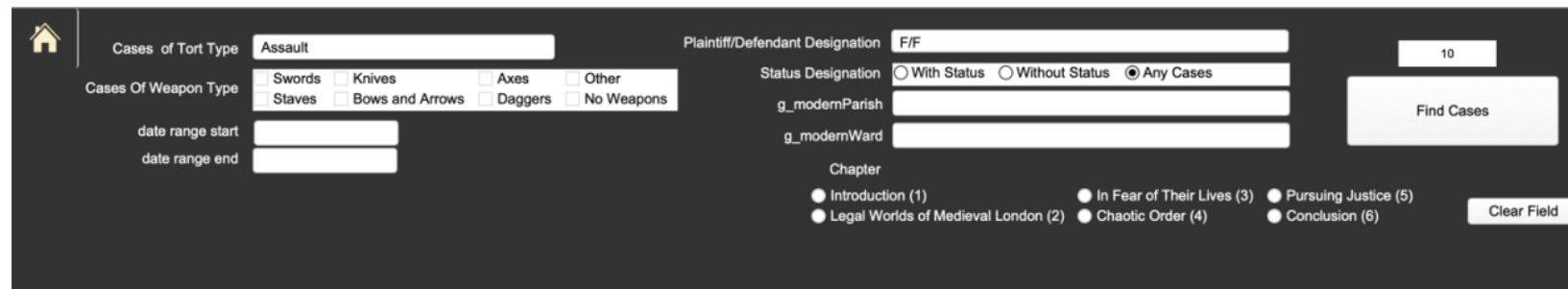

\begin{tabular}{|c|c|c|c|c|c|c|}
\hline CP 40/579, rot. 160 & Memo & \multirow[t]{2}{*}{ 个 } & \multirow{2}{*}{$\begin{array}{r}\text { CaseNumber } \\
\text { ID_Case }\end{array}$} & \multicolumn{2}{|l|}{ CP 40/579, rot. 160 [1] } & \multirow{10}{*}{$\begin{array}{l}\text { Other } \\
\text { No Weapons }\end{array}$} \\
\hline CP 40/583, rot. 274 & Memo & & & CP92 & & \\
\hline CP 40/594, rot. 135 & Memo & \multirow{2}{*}{\multicolumn{2}{|c|}{ WeaponsUsed }} & \multirow{2}{*}{$\begin{array}{l}x \text { Knives } \\
\text { Bows and Arrows }\end{array}$} & \multirow{2}{*}{$\begin{array}{l}\text { Axes } \\
\text { Daggers }\end{array}$} & \\
\hline CP 40/598, rot. 345 & Memo & & & & & \\
\hline CP 40/598, rot. 475 & Memo & & ModernParish & St. Margaret Moyses & & \\
\hline CP 40/602, rot. 116d & Memo & & ModernWard & Bread Street & & \\
\hline CP 40/602, rot. 171d & Memo & & DateOrTort & 7/20/1405 & & \\
\hline CP 40/606, rot. 236d & Memo & & & & & \\
\hline CP 40/619, rot. 179d & Memo & & & & & \\
\hline CP 40/619, rot. 597d & Memo & & & & & \\
\hline
\end{tabular}

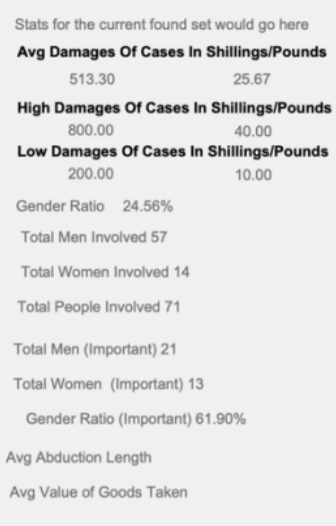

Image 10 - Example of Report Run Giving Average Damages in Pounds and Shillings for Assault Cases with Female Litigants, FileMaker Screenshot, Appendix H 


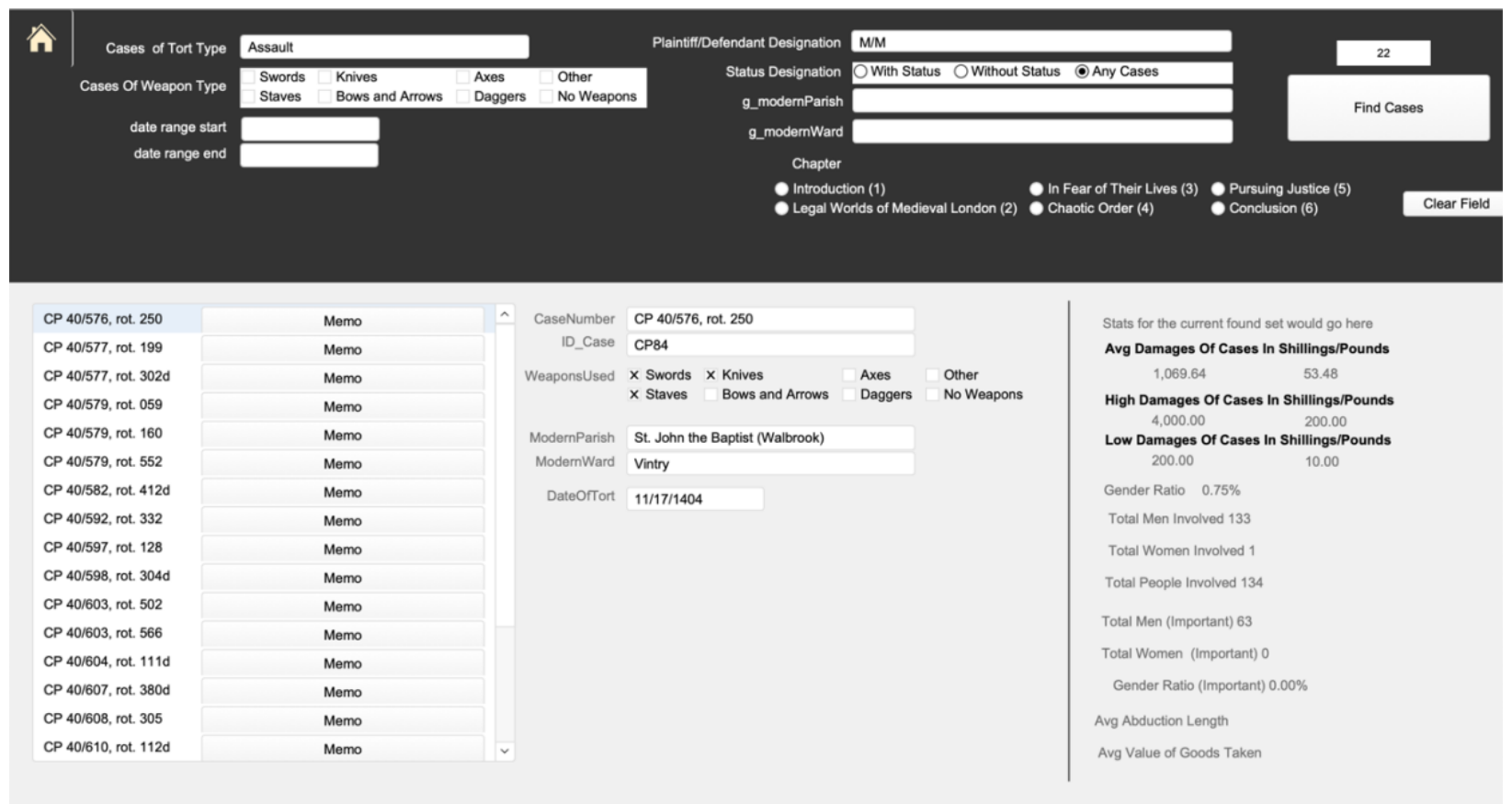

Image 11 - Example of Report Run Giving Average Damages in Pounds and Shillings for Assault Cases with Male Litigants, FileMaker Screenshot, Appendix H 


\section{Bibliography}

Primary Sources: Manuscript

London, London Metropolitan Archives

\section{CLA/024/02/001-003}

Kew, The National Archives

\begin{tabular}{|c|c|}
\hline CP 40/559, rot. 562 & CP 40/594, rot. 309d \\
\hline CP 40/560, rot. 109 & CP 40/594, rot. 499 \\
\hline CP 40/560, rot. 116 & CP 40/596, rot. 179 \\
\hline CP 40/568, rot. 054 & CP 40/597, rot. 128 \\
\hline CP 40/576, rot. $141 d$ & CP 40/597, rot. 210 \\
\hline CP 40/576, rot. 250 & CP 40/598, rot. $218 d$ \\
\hline CP 40/577, rot. 199 & CP 40/598, rot. $304 d$ \\
\hline CP 40/577, rot. $302 \mathrm{~d}$ & CP 40/598, rot. 345 \\
\hline CP 40/577, rot. 349 & CP 40/598, rot. $345 d$ \\
\hline CP 40/577, rot. 469 & CP 40/598, rot. 431 \\
\hline CP 40/578, rot. 116 & CP 40/598, rot. 475 \\
\hline CP 40/579, rot. 059 & CP 40/598, rots. $104-105(d)$ \\
\hline CP 40/579, rot. 160 & CP 40/599, rot. 548 \\
\hline CP 40/579, rot. 160 & CP 40/600, rot. $129 d$ \\
\hline CP 40/579, rot. 290 & CP 40/600, rot. 449 \\
\hline CP 40/579, rot. 304d & CP 40/601, rot. 139 \\
\hline CP 40/579, rot. 316 & CP 40/602, rot. $116 \mathrm{~d}$ \\
\hline CP 40/579, rot. 552 & CP 40/602, rot. $171 d$ \\
\hline CP $40 / 582$, rot. $102 d$ & CP 40/603, rot. $156 \mathrm{~d}$ \\
\hline CP 40/582, rot. 219 & CP 40/603, rot. 502 \\
\hline CP 40/582, rot. 412 & CP 40/603, rot. 528d \\
\hline $\mathrm{CP} 40 / 582$, rot. $412 \mathrm{~d}$ & CP 40/603, rot. 566 \\
\hline CP 40/582, rot. 506d & CP 40/603, rots. 392(d) \\
\hline CP $40 / 583$, rot. $232 \mathrm{~d}$ & CP 40/604, rot. $111 \mathrm{~d}$ \\
\hline CP 40/583, rot. 274 & CP 40/604, rot. 124 \\
\hline CP 40/585, rot. 106 & CP 40/605, rot. $334 d$ \\
\hline CP 40/585, rot. 210 & CP 40/605, rots. $318-318 d$ \\
\hline CP $40 / 585$, rot. $367 d$ & CP 40/606, rot. $236 \mathrm{~d}$ \\
\hline CP 40/587, rot. 220 & CP 40/606, rot. 406 \\
\hline CP 40/590, rot. $231 d$ & CP 40/606, rot. $487 \mathrm{~d}$ \\
\hline CP 40/590, rot. 328 & CP 40/607, rot. $380 d$ \\
\hline CP 40/592, rot. 332 & CP 40/607, rot. $380 d$ \\
\hline CP 40/594, rot. 135 & CP 40/608, rot. 305 \\
\hline CP 40/594, rot. 135 & CP 40/609, rot. $102 d$ \\
\hline
\end{tabular}

CP 40/610, rot. 112 d

CP 40/610, rot. 204d

CP 40/611, rot. 124

CP 40/611, rot. 457

CP 40/611, rot. 597

CP 40/612, rot. 128

CP 40/612, rot. 441

CP 40/614, rot. 357d

CP 40/615, rot. 445

CP 40/615, rot. 445d

CP 40/615, rot. 656

CP 40/616, rot. 247

CP 40/616, rot. 313d

CP 40/616, rot. 480

CP 40/617, rot. 117

CP 40/617, rot. 179

CP 40/617, rot. 254

CP 40/618, rot. 136d

CP 40/619, rot. 049

CP 40/619, rot. 179d

CP 40/619, rot. 359

CP 40/619, rot. 520

CP 40/619, rot. 597d

CP 40/650, rot. 395d

CP 40/665, rot. 453d

CP 40/667, rot. 390d

CP 40/670, rot. 326

CP 40/871, rot. 123

CP 40/872, rot. 442d

CP 40/951, rot. 358

CP 40/568, rot. 289d

CP 40/603, rot. 483d 


\section{Primary Sources: Published}

Attenborough, F.L. The Laws of the Earliest English Kings. New York: Russell \& Russell, 1963.

Blackstone, Sir William. Commentaries on the Laws of England: Book the Third. London: Dawsons of Pall Mall, 1966.

Blackstone, Sir William. Commentaries on the Laws of England: Book the First. London: Dawsons of Pall Mall, 1966.

“Civitas Londinum (1562?)." The Map of Early Modern London (2012): https://mapoflondon.uvic.ca/agas.htm.

"Fines for Divers and Other Counties: Henry IV," In A Calendar to the Feet of Fines for London and Middlesex: Volume 1, Richard I - Richard III, edited by W.J. Hardy, and W. Page, 233-34. London: Hardy \& Page, 1892.

R.A. Placita Latine Rediviva: A Book of Entries; Containing Perfect and Approved Precedents of Counts, Declarations, Barrs, Avowries, Replications, Pleas in Abatement, Issues, Judgments, As well as Actions Real as Personal, And Sundry other Entries; useful for all Clerks, Attorneys, and Practicers in the Courts at Westminster, and inferiour Courts. London: H. Layford, John Place, and T. Passet, 1673.

Robertson, A.J. The Laws of the Kings of England from Edmund to Henry I. New York: AMS Press, 1974.

Stow, John. The Survey of London: Conteyning The Originall, Antiquity, Increase, Moderne Estate, and Description of that City, Written in the Yeare 1598, by John Stow Citizen of London. London: John Windet, 1603.

The Statutes of the Realm, vol 2: 1377-1504. 2. London: 1816.

Townesend, George. A Preparative to Pleading Being a Work intended for the Instruction and Help of Young Clerks of the Court of Common Pleas. London: Israel Harrison, 1675.

\section{Secondary Sources}

Amussen, Susan Dwyer. "Punishment, Discipline, and Power: The Social Meanings of Violence in Early Modern England.” Journal of British Studies 34, no. 1 (1995): 1-34.

“Anglo-American Legal Tradition." O'Quinn Law Library at The University of Houston (2015): http://aalt.law.uh.edu.

Appleby, John C., and Paul Dalton, eds. Outlaws in Medieval and Early Modern England: Crime, Government and Society, c. 1066-c. 1600 Farnham, UK: Ashgate Publishing, 2009.

Arnold, Morris S. "Accident, Mistake, and Rules of Liability in the Fourteenth-Century Law of Torts." University of Pennsylvania Law Review 128 (1979): 361.

Baker, J.H. The Third University of England: The Inns of Court and the Common-Law Tradition. London: Selden Society, 1990.

Baker, J.H. "The Three Languages of the Common Law." McGill Law Journal 43 (1997): 5-24. Baker, J.H. An Introduction to English Legal History. Oxford: Oxford University Press, 2007.

Baker, J.H. The Order of Serjeants at Law: A Chronicle of Creations, with Related Texts and a Historical Introduction. London: Selden Society, 1984.

Baker, J.H. The Oxford History of the Laws of England, Vol. 6. Oxford: Oxford University Press, 2003. 
Baker, J.H. The Men of Court 1440 to 1550: A Prosopography of the Inns of Court and Chancery and the Courts of Law. Volume I, A to I. London: Selden Society, 2012.

Bardsley, Sandy. Venomous Tongues: Speech and Gender in Late Medieval England. Philadelphia: University of Pennsylvania Press, 2014.

Barron, Caroline M. Revolt in London: 11th to 15th June 1381. London: Museum of London, 1981.

Barron, Caroline M. London in the Later Middle Ages: Government and People, 1200-1500. Oxford: Oxford University Press, 2004.

Barron, Caroline M. "The Quarrel of Richard II with London, 1392-7," In Medieval London: Collected Papers of Caroline M. Barron, edited by Martha Carlin, and Joel T. Rosenthal, 27-56. Kalamazoo, MI: Medieval Institute Publications, 2017.

Beckerman, John. "The Forty-Shilling Jurisdictional Limit in Medieval English Personal Actions," In Legal History Studies, edited by Dafydd Jenkins, 110-17. London: University of Wales Press, 1975.

Bellamy, J.G. Criminal Law and Society in Late Medieval and Tudor England. New York: St. Martin's Press, 1984.

Bellamy, J.G. The Criminal Trial in Later Medieval England: Felony Before the Courts From Edward I to the Sixteenth Century. Toronto: University of Toronto Press, 1998.

Bellamy, J.G. Crime and Public Order in England in the Later Middle Ages. London: Routledge \& Kegan Paul, 1972.

Benham, Jenny. "Wounding in the High Middle Ages: Law and Practice," In The History of Medicine in Context: Wounds in the Middle Ages, edited by Anne Kirkham, and Cordelia Warr, 151-72. Farnham, UK: Ashgate Publishing, 2014.

Bentham, RW, and JM Bennett. "The Office of Prothonotary: Its Historical Development in England and in New South Wales." Sydney Law Review 3 (1959): 47-70.

Biancalana, Joseph. The Fee Tail and the Common Recovery in Medieval England. Cambridge: Cambridge University Press, 2001.

Blatcher, Marjorie. The Court of King's Bench, 1450-1550: A Study in Self-Help. London: Athlone Press, 1978.

Brand, Paul. "Delay in the English Common Law Courts (Twelfth to Fourteenth Centuries)," In The Law's Delay: Essays on Undue Delay in Civil Litigation, edited by C.H. van Rhee, 31-45. Antwerp: Intersentia, 2004.

Brand, Paul. "Judges and Juries in Civil Litigation in Later Medieval England: The Millon Thesis Reconsidered." Journal of Legal History 37, no. 1 (2016): 1-40.

Brand, Paul, and Joshua Getzler, eds. Judges and Judging in the History of the Common Law and Civil Law Cambridge: Cambridge University Press, 2012.

Briggs, Chris. "Manor Court Procedures, Debt Litigation Levels, and Rural Credit Provision in England, c. 1290-c. 1380." Law and History Review 24, no. 3 (2006): 519-58.

Brown, Warren C. Violence in Medieval Europe. Harlow, UK: Pearson Education Limited, 2011.

Brown, Warren C. "The Use of Norms in Disputes in Early Medieval Bavaria." Viator 30 (1999): 15-39.

Brown, Warren C. "Charters as Weapons: On the Role Played by Early Medieval Dispute Records in the Disputes They Record." Journal of Medieval History 28, no. 3 (2002): 227-48.

Brown, Warren C, and Piotr Górecki, eds. Conflict in Medieval Europe: Changing Perspectives on Society and Culture Farnham, UK: Ashgate Publishing, 2003. 
Brundage, James A. The Medieval Origins of the Legal Profession: Canonists, Civilians, and Courts. Chicago: University of Chicago Press, 2008.

Bryen, Ari Z. Violence in Roman Egypt. Philadelphia: University of Pennsylvania Press, 2013.

Burns, Kathryn. "Notaries, Truth, and Consequences." American Historical Review 110, no. 2 (2005): 350-79.

Burns, Kathryn. Into the Archive: Writing and Power in Colonial Peru. Durham, NC: Duke University Press, 2010.

Burns, Robert P. The Death of the American Trial. Chicago: University of Chicago Press, 2009.

Butler, Sara M. "The Law as a Weapon in Marital Disputes: Evidence From the Late Medieval Court of Chancery, 1424-1529." Journal of British Studies 43, no. 3 (2004): 291-316.

Butler, Sara M. "Runaway Wives: Husband Desertion in Medieval England." Journal of Social History 40, no. 2 (2006): 337-59.

Carrel, Helen. "The Ideology of Punishment in Late Medieval English Towns." Social History 34, no. 3 (2009): 301-20.

Cheney, C.R., and Michael Jones. A Handbook of Dates: For Students of British History. Cambridge: Cambridge University Press, 2004.

Clanchy, Michael T. From Memory to Written Record: England 1066-1307. Chichester: WileyBlackwell, 2013.

Clanchy, Michael T. "Magna Carta and the Common Pleas," In Studies in Medieval History Presented to R.H.C Davis, edited by R.H.C Davis, Henry Mayr-Harting, and R.I. Moore, 219-32. London: Hambledon Press, 1985.

Cockburn, J. S., and Thomas A. Green. Twelve Good Men and True: The Criminal Trial Jury in England, 1200-1800. Princeton: Princeton University Press, 2014.

Compton, Emily. "Property, Propriety, and Patriarchy: Abduction, Assault and Housebreaking in the Court of Common Pleas, 1399-1500," master's thesis., The University of Guelph, 2014.

Cooper, Alan. "The King’s Four Highways: Legal Fiction Meets Fictional Law." Journal of Medieval History 26, no. 4 (2000): 351-70.

Cunningham, Sean. "The Court of the King's Bench." Postgraduate Archival Training (PAST): Medieval Legal Records Workshop (2018):

Danbury, Elizabeth A, and Kathleen L Scott. "The Plea Rolls of the Court of Common Pleas: An Unused Source for the Art and History of Later Medieval England, 1422-1509." Antiquaries Journal 95 (2015): 157-210.

Davis, Natalie Zemon. Fiction in the Archives: Pardon Tales and Their Tellers in SixteenthCentury France. Stanford, CA: Stanford University Press, 1987.

Dean, Trevor. Crime in Medieval Europe: 1200-1550. Harlow, UK: Longman, 2001.

Dean, Trevor. "Theft and Gender in Late Medieval Bologna." Gender \& History 20, no. 2 (2008): 399-415.

Dinshaw, Carolyn. Getting Medieval: Sexualities and Communities, Pre-and Postmodern. Durham, NC: Duke University Press, 1999.

Dronzek, Anna. "Gendered Theories of Education in Fifteenth-Century Conduct Books," In Medieval Conduct, edited by Kathleen M. Ashley, and Robert L.A. Clark, 135-59. Minneapolis: University of Minnesota Press, 2001.

Dronzek, Anna. "Women and Property Conflicts in late Medieval England," In Women and Wealth in Late Medieval Europe, edited by Theresa Earenfight, 187-207. New York: Palgrave Macmillan, 2010. 
Dryburgh, Paul. "The Law and Legal Records: An Overview." Postgraduate Archival Training (PAST): Medieval Legal Records Workshop (2018):

Duffy, Eamon. The Stripping of the Altars: Traditional Religion in England, 1400-1580. New Haven: Yale University Press, 2005.

Dunn, Caroline. Stolen Women in Medieval England: Rape, Abduction, and Adultery, 11001500. Cambridge: Cambridge University Press, 2012.

Dunn, Diana E. S., ed. Courts, Counties and the Capital in the Later Middle Ages New York: St. Martin's Press, 1996.

Dyer, Christopher. Making a Living in the Middle Ages: The People of Britain, 850-1520. New Haven: Yale University Press, 2002.

Eisner, Manuel. "Long-Term Historical Trends in Violent Crime." Crime and Justice 30, no. 2003 (2003): 83-142.

Eisner, Manuel. "Interactive London Medieval Murder Map.” University of Cambridge: Institute of Criminology (2018): Accessed 3/15/2019, https://www.vrc.crim.cam.ac.uk/vrcresearch/london-medieval-murder-map.

Farge, Arlette. The Allure of the Archives. Translated by Thomas Scott-Railton. New Haven: Yale University Press, 2013.

Flanagin, D.Z. "Tyrannicide and the Question of (Il)licit Violence in the Fifteenth Century," In Nicholas of Cusa and Times of Transition: Essays in Honor of Gerald Christianson, edited by Thomas M. Izbicki, Jason Aleksander, and Donald F. Duclow, 48-63. Leiden: Brill, 2019.

Fletcher, Richard A. Bloodfeud: Murder and Revenge in Anglo-Saxon England. Oxford: Oxford University Press, 2003.

Gabriele, Matthew. "Why the Middle Ages Wasn't More Violent Than the Modern World (Despite What 'Game of Thrones' Says).” Forbes.com (2018): Accessed May 17, 2019, https://www.forbes.com/sites/matthewgabriele/2018/11/28/middle-ages-notmurder/\#76af72416bfc.

Gardner, Jane F. Women in Roman Law and Society. Bloomington, IN: Indiana University Press, 1986.

Gaskill, Malcolm. "Reporting Murder: Fiction in the Archives in Early Modern England." Social History 23, no. 1 (1998): 1-30.

Geary, Patrick J. The Myth of Nations. Princeton: Princeton University Press, 2003.

Geltner, Guy. The Medieval Prison: A Social History. Princeton: Princeton University Press, 2014.

Ginzburg, Carlo. The Cheese and the Worms: The Cosmos of a Sixteenth-Century Miller. Translated by Anne Tedeschi, and John Tedeschi. Baltimore, MD: John Hopkins University Press, 1982.

Ginzburg, Carlo. Ecstasies: Deciphering the Witches'Sabbath. Translated by Raymond Rosenthal. New York: Penguin Books, 1991.

Ginzburg, Carlo. The Night Battles: Witchcraft and Agrarian Cults in the Sixteenth and Seventeenth Centuries. Translated by Anne Tedeschi, and John Tedeschi. Baltimore, MD: John Hopkins University Press, 1992.

Given-Wilson, Chris. Henry IV. New Haven: Yale University Press, 2016.

Glymph, Thavolia. Out of the House of Bondage: The Transformation of the Plantation Household. Cambridge: Cambridge University Press, 2008. 
Goldberg, P.J.P. "Women,” In Fifteenth-Century Attitudes: Perceptions of Society in Late Medieval England, edited by Rosemary Horrox, 113-31. Cambridge: Cambridge University Press, 1994.

Gourlay, Kristi. "Roses and Thorns: The Prosecution of Rape in the Middle Ages." Medieval Life 5 (1996): 29-31.

Green, Richard Firth. A Crisis of Truth: Literature and Law in Ricardian England. Philadelphia: University of Pennsylvania Press, 1999.

Green, Thomas A. Verdict According to Conscience: Perspectives on the English Criminal Trial Jury, 1200-1800. Chicago: University of Chicago Press, 1985.

Green, Thomas A. "Societal Concepts of Criminal Liability for Homicide in Mediaeval England." Speculum 47, no. 4 (1972): 669-94.

Gundy, A. K. Richard II and the Rebel Earl. Cambridge: Cambridge University Press, 2013.

Hanawalt, Barbara. 'Of Good and Ill Repute': Gender and Social Control in Medieval England. Oxford: Oxford University Press, 1998.

Hanawalt, Barbara, and David Wallace. Medieval Crime and Social Control. Minneapolis: University of Minnesota Press, 1999.

Hanawalt, Barbara A. Ceremony and Civility: Civic Culture in Late Medieval London. Oxford: Oxford University Press, 2017.

Harding, Alan. The Law Courts of Medieval England. London: Allen \& Unwin, 1973.

Harmon, Louise. "Falling off the Vine: Legal Fictions and the Doctrine of Substituted Judgment." Yale Law Journal 100, no. 1 (1990): 1-71.

Harriss, Gerald. "Political Society and the Growth of Government in Late Medieval England." Past \& Present 138 (1993): 28-57.

Harriss, Gerald. Shaping the Nation. Oxford: Oxford University Press, 2006.

Hastings, Margaret. The Court of Common Pleas in Fifteenth Century England: A Study of Legal Administration and Procedure. Ithaca: Cornell University Press, 1947.

Helmolz, R.H. The Oxford History of the Laws of England, Vol. 1. Oxford: Oxford University Press, 2004.

Herrup, Cynthia B. A House in Gross Disorder: Sex, Law, and the 2nd Earl of Castlehaven. Oxford: Oxford University Press, 2001.

Holdsworth, William. A History of English Law, Vol 4. IV. London: Methuen \& Co, Ltd, 1923.

Hollond, HA. "Pleading and Proof at Common Law." Cambridge Law Journal 6, no. 1 (1936): $1-15$.

Hudson, John. The Formation of English Common Law: Law and Society in England From the Norman Conquest to Magna Carta. New York: Addison Wesley Longman, Ltd, 1996.

Hurl-Eamon, Jennine. Gender and Petty Violence in London, 1680-1720. Columbus: Ohio State University Press, 2005.

Hyams, Paul R. "Feud and the State in Late Anglo-Saxon England." Journal of British Studies 40, no. 1 (2001): 1-43.

Hyams, Paul R. Rancor \& Reconciliation in Medieval England. Ithaca: Cornell University Press, 2003.

“Inns of Chancery." Gray's Inn https://www.graysinn.org.uk/history/inns-chancery.

Jeffs, Robin. "The Poynings-Percy Dispute: An Example of the Interplay of Open Strife and Legal Action in the Fifteenth Century." Historical Research 34, no. 90 (1961): 148-64.

Johnson, Tom. "The Preconstruction of Witness Testimony: Law and Social Discourse in England before the Reformation." Law and History Review 32, no. 1 (2014): 127-47. 
Jones, Karen. Gender and Petty Crime in Late Medieval England. Woodbridge, UK: Boydell Press, 2006.

Kaeuper, Richard. Chivalry and Violence in Medieval Europe. Oxford: Oxford University Press, 1999.

Kamali, Elizabeth Papp. "Felonia Felonice Facta: Felony and Intentionality in Medieval England." Criminal Law and Philosophy 9, no. 3 (2015): 397-421.

Kane, Bronach, and Fiona Williamson, eds. Women, Agency and the Law, 1300-1700 London: Pickering \& Chatto, 2013.

Karras, Ruth Mazo. Common Women: Prostitution and Sexuality in Medieval England. Oxford: Oxford University Press, 1996.

Karras, Ruth Mazo. Sexuality in Medieval Europe: Doing Unto Others. New York: Routledge, 2005.

Keene, Derek. "Changes in London's Economic Hinterland as Indicated by Debt Cases in the Court of Common Pleas," In Trade, Urban Hinterlands and Market Integration, c 13001600, edited by James A. Galloway, 59-81. London: Centre for Metropolitan History, 2000.

Kesselring, Krista J. "Bodies of Evidence: Sex and Murder (or Gender and Homicide) in Early Modern England, c. 1500-1680.” Gender \& History 27, no. 2 (2015): 245-62.

Kittel, Ruth. "Rape in Thirteenth-Century England: A Study of the Common-Law Courts," In Women and the Law: The Social Historical Perspective, edited by D. Kelly Weisberg, 101-15. Cambridge, MA: Schenkman, 1982.

Kleineke, Hannes, and James Ross. "Just Another Day in Chancery Lane: Disorder and the Law in London's Legal Quarter in the Fifteenth Century." Law and History Review 35, no. 4 (2017): 1017-47.

Knowles, David, David M. Smith, Christopher Nugent Lawrence Brooke, and Vera C.M. London, eds. The Heads of Religious Houses: England and Wales, III. 1377-1540 Cambridge: Cambridge University Press, 2008.

Lambert, T. B. Law and Order in Anglo-Saxon England. Oxford: Oxford University Press, 2017.

Latham, R. E. Revised Medieval Latin Word-List from British and Irish Sources. Oxford: Oxford University Press, 1965.

Leveleux-Teixeira, Corinne. "Droit et vérité: le point de vue de la doctrine médiévale (XIIe-XVe siècles) ou la vérité entre opinion et fiction.” Bien Dire et Bien Aprandre 23 (2005): 333 49.

Liddy, Christian D. Contesting the City. Oxford: Oxford University Press, 2017.

Loengard, Janet. "What is a Nice (Thirteenth-Century) English Woman Doing in the King's Courts?," In The Ties that Bind: Essays in Medieval British History in Honor of Barbara Hanawalt, edited by Linda E. Mitchell, Katherine L. French, and Douglas L. Biggs, 5570. Farnham, UK: Ashgate Publishing, 2011.

Lumineau, Fabrice, and Joanne E. Oxley. "Let's Work It Out (or We'll See You in Court): Litigation and Private Dispute Resolution in Vertical Exchange Relationships." Organization Science 23, no. 3 (2012): 820-34.

Mackman, Jonathan. "'Hidden Gems' in the Records of the Common Pleas: New Evidence on the Legacy of Lucy Visconti," In Rule, Redemption, and Representations in Late Medieval England and France, edited by Linda Clark, 59-72. Woodbridge, UK: Boydell Press, 2008. 
Mackman, Jonathan, and Stevens, Matthew Frank. "Court of Common Pleas: The National Archives, CP40 1399-1500.” British History Online (2010): Accessed 3/16/2019, https://www.british-history.ac.uk/no-series/common-pleas/1399-1500.

Mackman, Jonathan, and Stevens, Matthew Frank. "Introducing the Common Pleas." Court of Common Pleas: The National Archives, CP40: 1399-1500 British History Online (2010): http://www.british-history.ac.uk/report.aspx?compid=119287.

Mackman, Jonathan, and Stevens, Matthew Frank. "Introduction to the Edition." Court of Common Pleas: The National Archives, CP40: 1399-1500 British History Online (2010): http://www.british-history.ac.uk/report.aspx?compid=119286.

Maddern, Philippa C. Violence and Social Order: East Anglia 1422-1442. Oxford: Oxford University Press, 1992.

Masschaele, James. Jury, State, and Society in Medieval England. New York: Palgrave Macmillan, 2008.

McHaffie, M. W. "Law and Violence in Eleventh-Century France." Past \& Present 238, no. 1 (2018): 3-41.

McIntosh, Marjorie Keniston. Controlling Misbehavior in England, 1370-1600. Cambridge: Cambridge University Press, 1998.

McIntosh, Marjorie Keniston. "The Benefits and Drawbacks of Femme Sole Status in England, 1300-1630." Journal of British Studies 44, no. 3 (2005): 410-38.

McSheffrey, Shannon. Marriage, Sex and Civic Culture in Late Medieval London. Philadelphia: University of Pennsylvania Press, 2006.

McSheffrey, Shannon. "Detective Fiction in the Archives: Court Records and the Uses of Law in Late Medieval England." History Workshop Journal 65, no. 1 (2008): 65-78.

McSheffrey, Shannon. "The Slaying of Sir William Pennington: Legal Narrative and the Late Medieval English Archive." Florilegium 28 (2011): 169-203.

McSheffrey, Shannon. Seeking Sanctuary: Crime, Mercy, and Politics in English Courts, 14001550. Oxford: Oxford University Press, 2017.

Menuge, Noël James. "Reading Constructed Narratives: An Orphaned Medieval Heiress and the Legal Case as Literature," In Medieval Women: Texts and Contexts in Late Medieval Britain, edited by Jocelyn Wogan-Browne, 115-29. Turnhoult: Brepols, 2000.

Mertes, Kate. "Aristocracy," In Fifteenth-Century Attitudes: Perceptions of Society in Late Medieval England, edited by Rosemary Horrox, 42-60. Cambridge: Cambridge University Press, 1994.

“asaut and assaut, n." Middle English Dictionary at the Medieval English Compendium. 2018. https://quod.lib.umich.edu/m/middle-english-dictionary/dictionary/MED2555 (accessed 3/24/2019).

Miller, William Ian. Humiliation: And Other Essays on Honor, Social Discomfort, and Violence. Ithaca: Cornell University Press, 1995.

Miller, William Ian. Eye for an Eye. Cambridge: Cambridge University Press, 2005.

Milsom, S.F.C. Historical Foundations of the Common Law. London: Butterworths, 1981.

Milsom, S.F.C. Studies in the History of the Common Law. London: Hambledon Press, 1985.

Musson, Anthony. Medieval Law in Context: The Growth of Legal Consciousness from Magna

Carta to the Peasants' Revolt. Manchester: Manchester University Press, 2001.

Musson, Anthony, and W. M. Ormrod. The Evolution of English Justice: Law, Politics, and Society in the Fourteenth Century. New York: St. Martin's Press, 1999. 
Musson, Anthony J. “Turning King's Evidence: the Prosecution of Crime in Late Medieval England." Oxford Journal of Legal Studies 19, no. 3 (1999): 467-80.

Neville, Cynthia J. "Common Knowledge of the Common Law in Later Medieval England." Canadian Journal of History 29, no. 3 (1994): 461-78.

Orr, Patricia. "Men's Theory and Women's Reality: Rape Prosecutions in the English Royal Courts of Justice, 1194-1222," In The Rusted Hauberk: Feudal Ideals of Order and Their Decline, edited by Liam O. Purdon, and Cindy L. Vitto, 121-59. Gainseville, FL: University Press of Florida, 1994.

“assault, n.” OED Online. 2018. Oxford University Press. http://www.oed.com/view/Entry/11746 (accessed January 17, 2019).

"assault, v." OED Online. 2018. Oxford University Press. http://www.oed.com/view/Entry/11747 (accessed January 17, 2019).

"messuage, n." OED Online. 2018. Oxford University Press. http://www.oed.com/view/Entry/117128 (accessed February 10, 2019).

Palliser, D.M. "Urban Society," In Fifteenth-Century Attitudes: Perceptions of Society in Late Medieval England, edited by Rosemary Horrox, 132-49. Cambridge: Cambridge University Press, 1994.

Palmer, Robert C. The Whilton Dispute, 1264-1380 A Social-Legal Study of Dispute Settlement in Medieval England. Princeton: Princeton University Press, 1984.

Palmer, Robert C. English Law in the Age of the Black Death, 1348-1381: A Transformation of Governance and Law. Chapel Hill: University of North Carolina Press, 1993.

Payling, S. J. "Arbitration, Perpetual Entails and Collateral Warranties in Late-Medieval England: A Case Study.” Journal of Legal History 13, no. 1 (1992): 32-62.

Phipps, Teresa. "Misbehaving Women: Trespass and Honor in Late Medieval English Towns." Historical Reflections 43, no. 1 (2017): 62-76.

Plucknett, Theodore Frank Thomas. A Concise History of the Common Law. Rochester, NY: The Lawyers Co-Operative Publishing Company, 1929.

Pollard, A. J. Late Medieval England, 1399-1509. Harlow, UK: Pearson Education Limited, 2000.

Pollock, Sir Frederick, and Frederic William Maitland. The History of English Law Before the Time of Edward I. Cambridge: Cambridge University Press, 1895.

Poos, L.R., and Martha D. Rust. "Of Piers, Polltaxes and Parliament: Articulating Status and Occupation in Late Medieval England." Fragments: Interdisciplinary Approaches to the Study of Ancient and Medieval Pasts 5 (2016): 96-127.

Powell, Edward. "Arbitration and the Law in England in the Late Middle Ages (The Alexander Prize Essay)." Transactions of the Royal Historical Society 33 (1983): 49-67.

Powell, Edward. "Settlement of Disputes by Arbitration in Fifteenth-Century England." Law and History Review 2, no. 1 (1984): 21-43.

Powell, Edward. "Jury Trial at Gaol Delivery in the Late Middle Ages The Midland Circuit, 1400-1429," In Twelve Good Men and True: The Criminal Trial Jury in England, 12001800, edited by J. S. Cockburn, and Thomas A. Green, 78-116. Princeton: Princeton University Press, 1988.

Powell, Edward. Kingship, Law, and Society: Criminal Justice in the Reign of Henry V. Oxford: Clarendon Press, 1989.

Pythian-Adams, Charles. "Rituals of Personal Confrontation in Late Medieval England." Bulletin of the John Rylands Library 73, no. 1 (1991): 65-90. 
Raggio, Osvaldo. Feuds and State Formation, 1550-1700. Translated by Matthew A. Vester. New York: Palgrave Macmillan, 2018.

Rappaport, Steve. Worlds Within Worlds: Structures of Life in Sixteenth-Century London. Cambridge: Cambridge University Press, 2002.

Rawcliffe, Carole. "Ninezergh, John (d. 1420), of Ninezergh, Westmld.," In The History of Parliament: the House of Commons, 1386-1421, edited by J.S. Roskell, Linda Clark, and Carole Rawcliffe, Suffolk: Boydell \& Brewer, 1993.

Rogers, Euan. "The Court of Common Pleas." Postgraduate Archival Training (PAST): Medieval Legal Records Workshop (2018):

Rosenthal, Joel Thomas. Telling Tales: Sources and Narration in Late Medieval England. University Park, PA: Pennsylvania State University Press, 2003.

Sartore, Melissa. Outlawry, Governance, and Law in Medieval England. New York: Peter Lang Inc., 2013.

Saul, Nigel, Jonathan Mackman, and Christopher Whittick. "Grave Stuff: Litigation With a London Tomb-Maker in 1421." Historical Research 84, no. 226 (2011): 572-85.

Schofield, Phillipp R. "Trespass Litigation in the Manor Court in the Late Thirteenth and Early Fourteenth Century," In Survival and Discord in Medieval Society: Essays in Honour of Christopher Dyer, edited by Richard Goddard, John Langdon, and Miriam Müller, 14560. Turnhout: Brepols, 2010.

Sharpe, R.R. "Introduction," In Calendar of Wills Proved and Enrolled in the Court of Husting, London: Part 1, 1258-1358, edited by R.R. Sharpe, ii-xlviii. London: Her Majesty's Stationery Office, 1889.

Skoda, Hannah. Medieval Violence: Physical Brutality in Northern France, 1270-1330. Oxford: Oxford University Press, 2013.

Smail, Daniel Lord. The Consumption of Justice: Emotions, publicity, and legal culture in Marseille, 1264-1423. Ithaca: Cornell University Press, 2013.

Smail, Daniel Lord. Legal Plunder: Household and Debt Collection in Medieval Europe. Cambridge, MA: Harvard University Press, 2016.

Smail, Daniel Lord, and Kelly Gibson. Vengeance in Medieval Europe. Toronto: University of Toronto Press, 2009.

Smith, Carrie. "Medieval Coroners' Rolls: Legal Fiction or Historical Fact?," In Courts, Counties and the Capital in the Later Middle Ages, edited by Diana E. S. Dunn, 93-116. New York: St. Martin's Press, 1996.

Stamper, Kory. "Where Did the Phrase "get medieval on your ass" Come From?" A.V. Club's Pop Lexicon (2018): Accessed 3/14/2019, https://www.avclub.com/where-did-thephrase-get-medieval-on-your-ass-come-fr-1823196177.

Stevens, Matthew Frank. "Failed Arbitrations before the Court of Common Pleas: Cases Relating to London and Londoners, 1400-1468." Journal of Legal History 31, no. 1 (2010): 2144.

Stevens, Matthew Frank. "London Creditors and the Fifteenth-Century Depression." Economic History Review 69, no. 4 (2016): 1083-107.

Stevens, Matthew Frank. "Londoners and the Court of Common Pleas," In London and Beyond: Essays in Honour of Derek Keene, edited by Matthew Davies, and James A. Galloway, 225-45. London: Institute of Historical Research, 2012. 
Stevens, Matthew Frank. "London Women, the Courts and the 'Golden Age': A Quantitative Analysis of Female Litigants in the Fourteenth and Fifteenth Centuries." London Journal 37, no. 2 (2013): 67-88.

Stevens, Matthew Frank. "London's Married Women, Debt Litigation and Coverture in the Court of Common Pleas," In Married Women and the Law in Premodern Northwest Europe, edited by Cordelia Beattie, and Matthew Frank Stevens, 115-31. Woodbridge, UK: Boydell Press, 2013.

Storey, R.L. The End of the House of Lancaster. London: Barrie and Rockliff, 1966.

Stretton, Tim. Women Waging law in Elizabethan England. Cambridge: Cambridge University Press, 2005.

Sutherland, Donald W. "Legal Reasoning in the Fourteenth Century: The Invention of 'Color' in Pleading," In On the Laws and Customs of England: Essays in Honor of Samuel E. Thorne, edited by Samuel E. Thorne, and Morris S. Arnold, 182-94. Chapel Hill: University of North Carolina Press, 1981.

Tarantino, Quentin, and Roger Avary. Pulp Fiction. DVD. Directed by Quentin Tarantino. Los Angeles: Miramax, 1994.

“Technical Methods." British History Online (2010): https://www.britishhistory.ac.uk/about\#technical.

Archives, The National. "Records of the Court of Common Pleas and other Courts." http://discovery.nationalarchives.gov.uk/details/r/C61.

Thrupp, Sylvia L. The Merchant Class of Medieval London, 1300-1500. Lansing: University of Michigan Press, 1989.

Trouillot, Michel-Rolph. Silencing the Past: Power and the Production of History. Boston: Beacon Press, 1995.

Tucker, Penny. Law Courts and Lawyers in the City of London 1300-1550 (Cambridge Studies in English Legal History). Cambridge: Cambridge University Press, 2007.

Turner, Ralph V. "The Origins of Common Pleas and King's Bench." American Journal of Legal History 21, no. 3 (1977): 238-54.

Walker, Garthine. Crime, Gender and Social Order in Early Modern England. Cambridge: Cambridge University Press, 2003.

Walker, Garthine. "Homicide, Gender, and Justice," In Crime, Gender and Social Order in Early Modern England, 113-58. Cambridge: Cambridge University Press, 2003.

Walker, Garthine. "Women, Theft and the World of Stolen Goods," In Women, Crime and the Courts in Early Modern England, edited by Jennifer Kermode, and Garthine Walker, 81105. Chapel Hill: University of North Carolina Press, 1994.

Walker, Sue Sheridan. "The Feudal Family and the Common Law Courts: The Pleas Protecting Rights of Wardship and Marriage, c. 1225-1375." Journal of Medieval History 14, no. 1 (1988): 13-31.

Watts, John. The Making of Polities. Cambridge: Cambridge University Press, 2009.

Whitman, James Q. "Origins of Law and the State: Supervision of Violence, Mutilation of Bodies, or Setting of Prices, At the." Chicago-Kent Law Review 71 (1995): 41.

Whitman, James Q. "Between Self-Defense and Vengeance/between Social Contract and Monopoly of Violence." Tulsa Law Review 39 (2003): 901.

Wickham, Chris. Courts and Conflict in Twelfth-Century Tuscany. Oxford: Oxford University Press, 2003. 
Winter, Christine. "Prisons and Punishments in Late Medieval London," PhD diss., Royal Holloway, University of London, 2012.

Woodbine, George E. "Origins of the Action of Trespass." Yale Law Journal 33, no. 8 (1924): 799-816.

Woodbine, George E. “Origins of the Action of Trespass.” Yale Law Journal 34, no. 4 (1925): 343-70.

Wormald, Patrick. Legal Culture in the Early Medieval West: Law as Text, Image, and Experience. London: Hambledon Press, 1999.

Wright, Sharon Hubbs. "Women in the Northern Courts: Interpreting Legal Records of Familial Conflict In Early Fifteenth-Century Yorkshire." Florilegium 19 (2002): 27-48.

Youngs, Deborah. "'She Hym Fresshely Folowed and Pursued': Women and Star Chamber in Early Tudor Wales," In Women, Agency and the Law, 1300-1700, edited by Bronach Kane, and Fiona Williamson, 89-102. London: Pickering \& Chatto, 2013.

Zell, Michael, and Karen Jones. "Bad Conversation? Gender and Social Control in a Kentish Borough, c. 1450-c. 1570." Continuity and Change 13, no. 1 (1998): 11-33. 